\title{
ILLINOIS NATURAL HISTORY SURVEY
}

\section{Bulletin}

\section{A Comparative Study of \\ Bird Populations in Illinois, \\ 1906-1909 and 1956-1958}

RI GHARD R. GRABER

JEAN W. GRABER 



\section{ILLINOIS NATURAL HISTORY SURVEY}

\section{Bulletin}

Volume 28, Article 3

October, 1963

Printed by Authority of the State of Illinois

\section{A Comparative Study of Bird Populations in Illinois, 1906-1909 and 1956-1958}

RICHARD R. GRABF, R

JEAN W. GRABER 


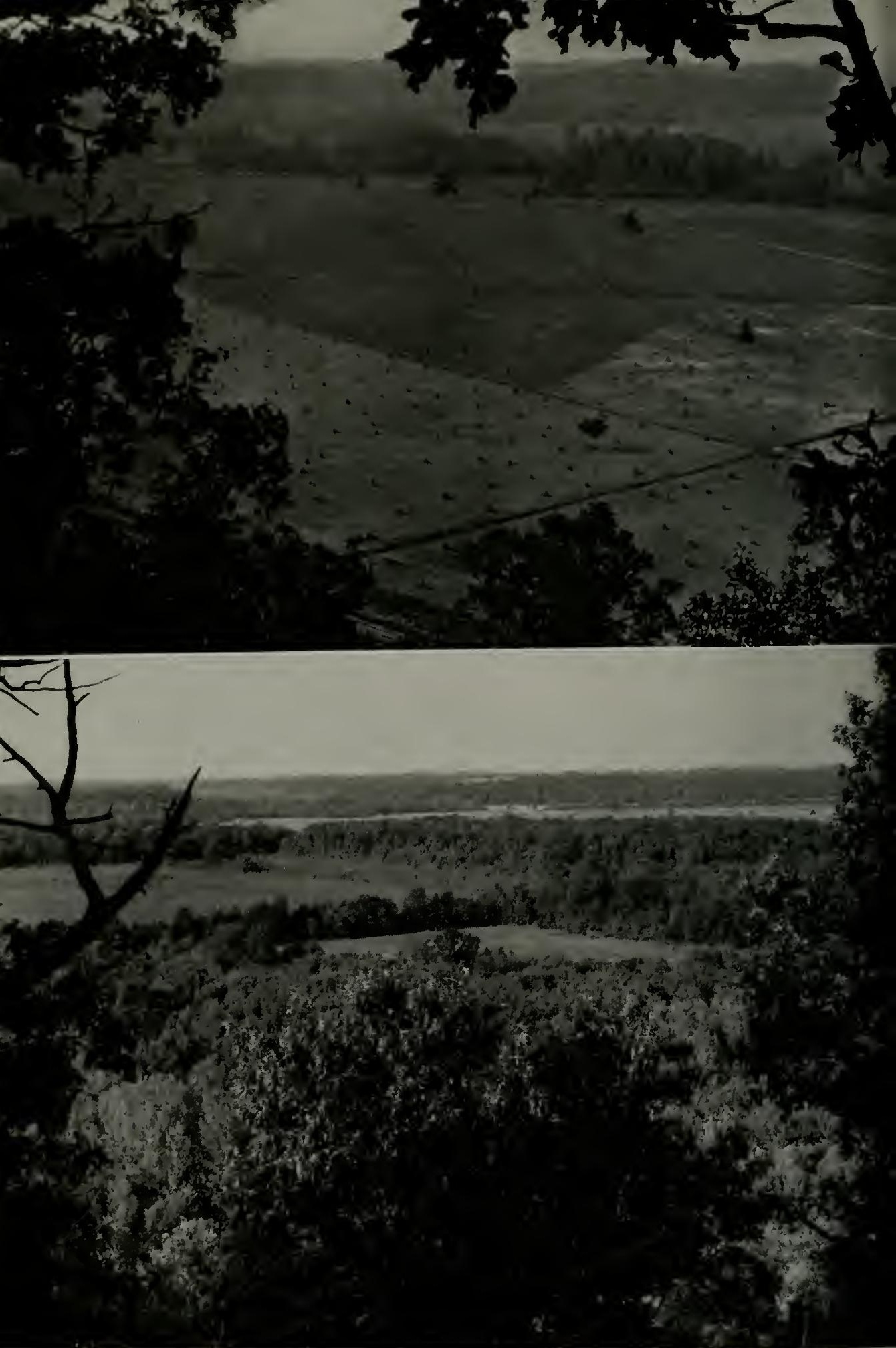

View of floodplain in Pope County, southern Illinois, 1907 and 1963.

Upper picture taken from cliff 1 mile east of Brownfield, June 27, 1907, by Alfred O. Gross. Lower picture, same area as upper picture; taken May 19, 1963, by Jean W. Graber. Several of the cultivated fields of the upper picture have been filled in with forest. Tree growth conceals the railroad tracks visible in the foreground of the upper picture. 

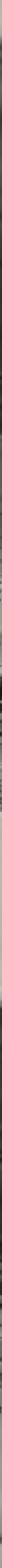

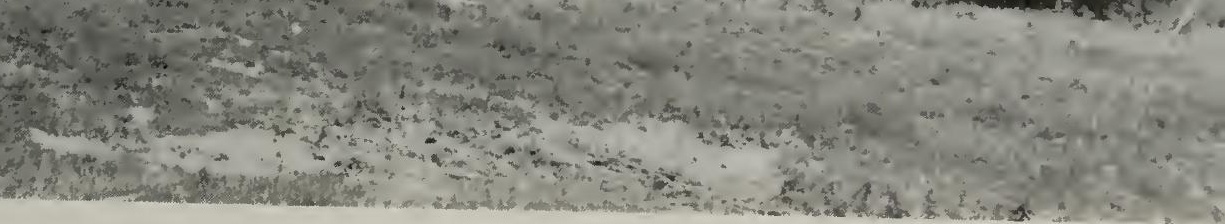

View of wooded hills in Hardin County, southern Illinois, 1907 and 1963.

Upper picture taken from the east edge of Shetlerville, June 29, 1907, by Alfred (). Gross.

Lower picture, same area as upper picture; taken May 19, 1963, hy Richard R. Graber. pasturea shows fewer changes in a half century than most Illinois areas censused. Overgrazel pasture has replaced cultivated fields shown in the upper picture. 
Мethods ..................383

Forbes-Gross Strip Census. . . . . . . . .383

Evaluation of Strip Census. . . . . . . 389

Weather Patterns of Census Years. 393

Bird Populations in Sumier

Habitats .......................

Cornfields (Summer) ..............397

Soybean Fields (Summer).........401

Plowed Fields (Summer) .........401

Oat Fields (Summer)...........401

Wheat Fields (Summer)........407

Pastures (Summer) ............408

Ungrazed Grasslands (Summer) . . . . 412

Fallow Fields (Summer)..........t13

Mixed Hayfields (Summer).......t14

Clover Fields (Summer)..........18

Red Clover .................418

Sweet Clover................... +20

Alfalfa Fields (Summer).......... 421

Marshland (Summer) ........... 22

Shrub-Grown Areas (Summer) .....t24

Orchards (Summer).............429

Forests (Summer)............. +30

Urban Residential Areas (Summer) . .436

Comparison of Data for Summer

Habitats ................ 37

Number of Birds.............. 38

Number of Species............439

Statewide Summer Populations. . . . . 440

Bird Populations in Winter

Habitats ...............443

Cornfields (Winter)............443

Soybean Stubble (Winter)........447

Plowed Fields (Winter) ........... .448

Small Grain Stubble Fields (Winter) 448

Wheat Fields (Winter)..........449

Pastures (Winter)..............451

Fallow Fields (Winter) ......... 452

Hayfields (Winter)........... . 452

Shrub Areas (Winter) ........... 452

Forests (Winter) .............453

Comparison of Data for Winter

Habitats ................453

Number of Birds.............. 456

Number of Species.............456

Statewide Winter Populations......456

Account of Species............ 458

Avifaunal Differences Between

Censuses ................ +63

Annotated List of Common Species. . 463

Turkey Vulture .............. . 464

Red-Tailed Hawk............ 64

Sparrow Hawk............. 465

Bobwhite .................466

Killdeer ..................67

Upland Plover...............468
Mourning Dove............... 69

Cuckoos ...................472

Chimney Swift...............472

Yellow-Shafted Flicker......... 473

Red-Bellied Woodpecker........474

Red-Headed Woodpecker........474

Downy Woodpecker.............755

Eastern Kingbird............476

Horned Lark................ +77

Barn Swallow...............478

Blue Jay.................. 479

Common Crow................480

Chickadees ...............481

Tufted Titmouse..............482

Mockingbird ...............483

Catbird .................. 483

Brown Thrasher.............484

Robin ....................485

Eastern Bluebird............486

Starling ...............486

Yellowthroat...............487

House Sparrow.............488

Bobolink .................489

Meadowlarks ..................489

Redwinged Blackbird...........490

Orchard Oriole.............491

Common Grackle..............492

Brown-Headed Cowbird.......... 492

Cardinal .................493

Indigo Bunting. . . . . . . . . . . 494

Dickcissel ................495

American Goldfinch............495

Savannah Sparrow............496

Grasshopper Sparrow..........496

Vesper Sparrow..............497

Lark Sparrow...............497

Slate-Colored Junco...........497

Tree Sparrow...............498

Chipping Sparrow............498

Field Sparrow...............498

Song Sparrow................499

Lapland Longspur............500

Discussion ...................500

Events Previous to 1800 .........501

Development of Managed Habitats. .502

Specific Changes in Avifauna.......503

Specialization in Managed $\mathrm{Habitats.} 504$

Population Density and Avifaunal

Variety ..................507

Population Changes and Latitude....508

Range Extensions................508

Habitats and the Future of the

Avifauna .................50

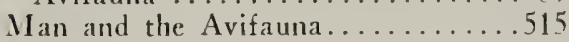

Literature Citen.................. 516

INDEX ..................... . . 519

This paper is printed by authority of the State of Illinois, IRS Ch. 127, Par. 58.12. It is a contribution from the Section of Wildlife Research of the Illinois Natural History Survey. Dr. Richard R. Graber is W'ildlife Associate with that section. Dr. Jean $\boldsymbol{W}^{\prime}$. Graber is Research Associats in Animal Scienre, University of Illinois. 

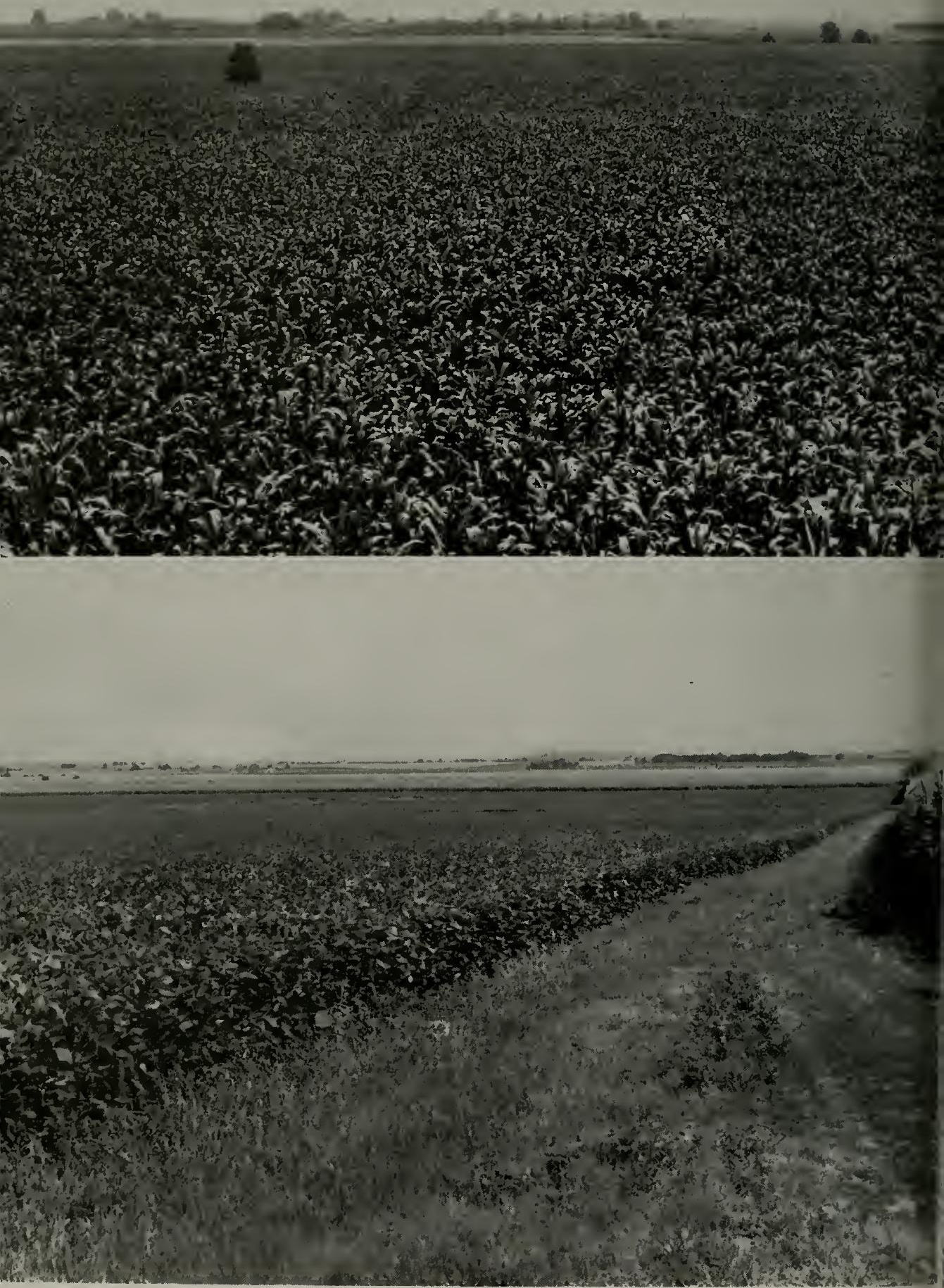

Landscape in Sangamon County, central Illinois, 1907 and 1962.

Upper picture taken one-fourth mile north of Buffalo Hart, June 2+, 1907, by Alfred $U$. Gross. Cornfields have comprised the largest Illinois habitat for at least the past 100 years.

Lower picture, same area as upper picture; taken August 2, 1962, by James S. Ayars. Soybeans (left foreground) came into wide use after 1920 and by 1957 occupied about 5,000,000 acres of Illinois land. 


\title{
A Comparative Study of Bird Populations in Illinois,
}

1906-1909 and 1956-1958

\author{
RICHARD R. GRABER \\ JEAN W. GRABER
}

()i August 29, 1906, Alfred O. Gross and Howard A. Ray, working for the Illinois State Laboratory of Natural History (a parent organization of the Illinois Natural History Survey) under the direction of Stephen A. Forbes, hegan a series of statewide, crosi-country censuses of birds in Illinois. These censuses were continued at intervals until September, 1909 , and the data collected were published in a series of papers (Forbes 1907, 1908, 1913; Forbes \& Gross 1921, 1922, 1923 ) that provided a quantitative record of the Illinois bird populations of that period and a potential hasis for evaluating the adjustment of bird populations to a changing environment. In 1956-1958, we conducted statewide censuses similar to those of the 1906-1909 survey. In this paper we present an analysis of our field data and compare these data with those from the first survey.

For suggesting and encouraging this study we are indehted to Dr. Harlow B. Mills and Dr. Thomas G. Scott of the Illinois Natural History Survey. Mr. Ronald F. Labisky of the Survey provided data on pheasant populations in a study area near Sibley, Illinois. Mr. John Ames and Mr. Herbert Brucker, both of Sibley, permitted us to establish and use special study areas on their lands. Mr. John Hill, Urbana, checked some of our calculations.

IVe are particularly grateful to Dr. Alfred O. Gross, Emeritus Professor of Biology at Bowdoin College, who presented us with all of the original field notes, journals, and photographs made on the first series of strip censuses conducted in Illinois (1906-1909) and encouraged our follow-up study. Finally, we are indebted to Mr. James S. Ayars of the Illinois Natural History Survey, who edited the manuscript.

\section{METHODS}

For an excellent review and discussion of measuring bird populations by various methods, we refer the reader to Kendeigh $(19+t)$. Here we need a brief summary of only the Forbes-Gross method, the strip census method used in the 1906-1909 and the 1956-1958 surveys.

\section{Forbes-Gross Strip Census}

'The Forhes-Gross method of censusing was described in essence by Forbes $(1907: 307)$, who stated that two observers "were sent into the field under instructions to traverse the state in various directions, traveling always in straight lines and always thirty yards apart, and noting and recording the species, numbers, and exact situation of all birds flushed by them on a strip fifty yards in width, including also those crossing this strip within one hundred yards to their front. No attention is paid by them, for this purpose, to any other birds."

Forbes likened the census operation to "a gigantic sweep-net 150 feet wide and 300 feet deep, so drawn across the country day by day as to capture every bird which comes in its way; . . " Certain details of the method were subsequently modified in the field, but the census techniques used during most of the survey by Gross and Ray in 1906-1909 were close to those described by Forbes \& Gross (1921:1-2). Our ultimate authority in determining the census technique actually used by the two observers in 1906-1909 has been the correspondence, journals, and original field notes of Dr. Alfred O. Gross.

In open-field hahitats (cornfields, soybean fields, and plowed ground), the two observers stayed 30 yards apart as they censused and counted all birds within or crosing a strip 50 yards in width in line with the observers and 100 yards to the front. In more dense habitats (orchards, forest, shrub-grown areas, and hayfields), the observers maintained a distance of 20 yards between them and censused a 30 yard strip. 'They traveled at the rate of about $+0-50$ minutes per mile. 


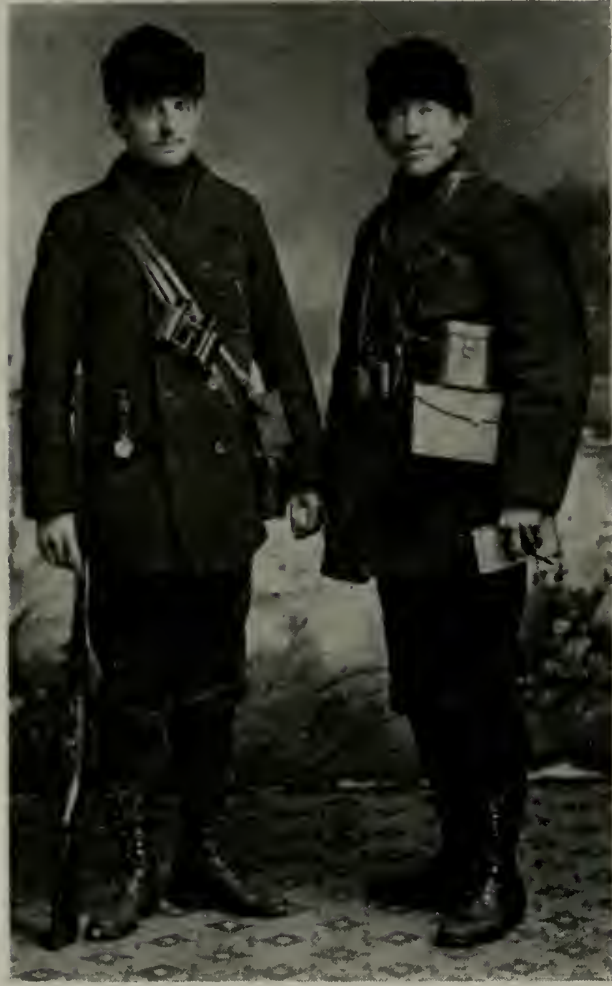

Fig. 1.-Alfred O. Gross, right, and Howard A. Ray as they appeared with winter field equipment at the time of the 1906-1909 bird censuses in Illinois.

Usually, censusing was started shortly iffer daybreak and continued, with interruptions, until late afternoon. No censuses were made during periods of inclement weather, that is, when there was precipitation or very strong wind. The distance traveled in each habitat was paced, tallied with a hand counter, and recorded. Other pertinent information was recorded: the date, time of day, locality, cloud condition, temperature, and number of each species of bird in each habitat. Examples of the type of field notes taken were published by Forbes \& Gross (1923:4+8-9).

In censusing, Gross and Ray chose the general routes (Forbes \& Gross 1921, frontispiece) that they would travel, that is, between certain cities or other landmarks, but the censusing wals random in the sense that the habitats were not chosen arbitrarily but were censused as they were encountered along the straight-line routes.
Some of the areas censused by Gross and Ray are pictured is frontispieces and others as figs. 16, 20,21, 29, and 30. Gross and Ray in winter field clothes and Gross on summer ficld trips are shown in figs. 1,2 , and 3 .

In 1956-1958, we censused in most of the counties that Gross and Ray had censused, fig. $t$, although we did not duplicate their routes exactly. After driving into a county, we deliberately chose a starting point in an area that seemed to represent the region. From the starting point, we walked a census strip along the perimeter of a square 1.5 to 2 miles on each side and returned ultimately to the starting point. Our rate of coverage, +550 minutes per mile, was comparable to that of Gross and Ray. Though we deliberately chose each census area, we did

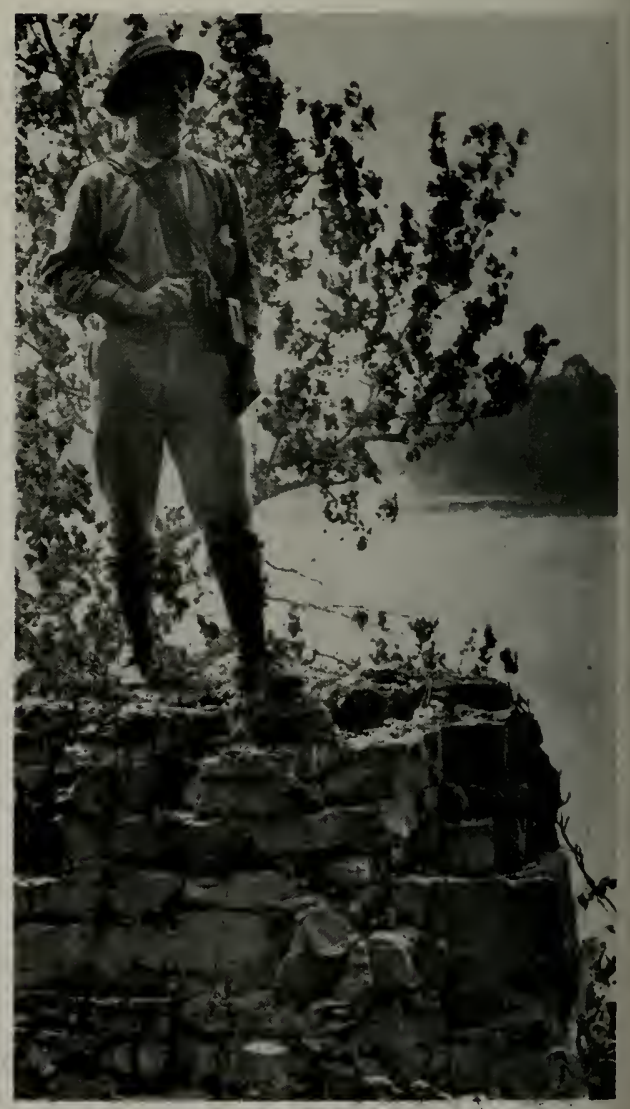

Fig. 2.-Alfred U. Gross on rocks along the Ohio River near Elizabethtown, Illinois, June $30,1907$. 
not arbitrarily select habitats, but censused all habitats as we encountered them along our straight-line routes. 'Thus, the habitat coverage in all our regular censusing was random.

In the summer of 1958 , we did supplementary censusing in addition to our regular censusing; we deliberately chose and nois at all seasons of the year, but because of the especially variable nature of bird populations in the migration seasons we decided to limit our censuses to the winter and summer seasons. In Illinois, spring migration of birds begins in February and extends at least through the first week in June. For some species, fall mi-

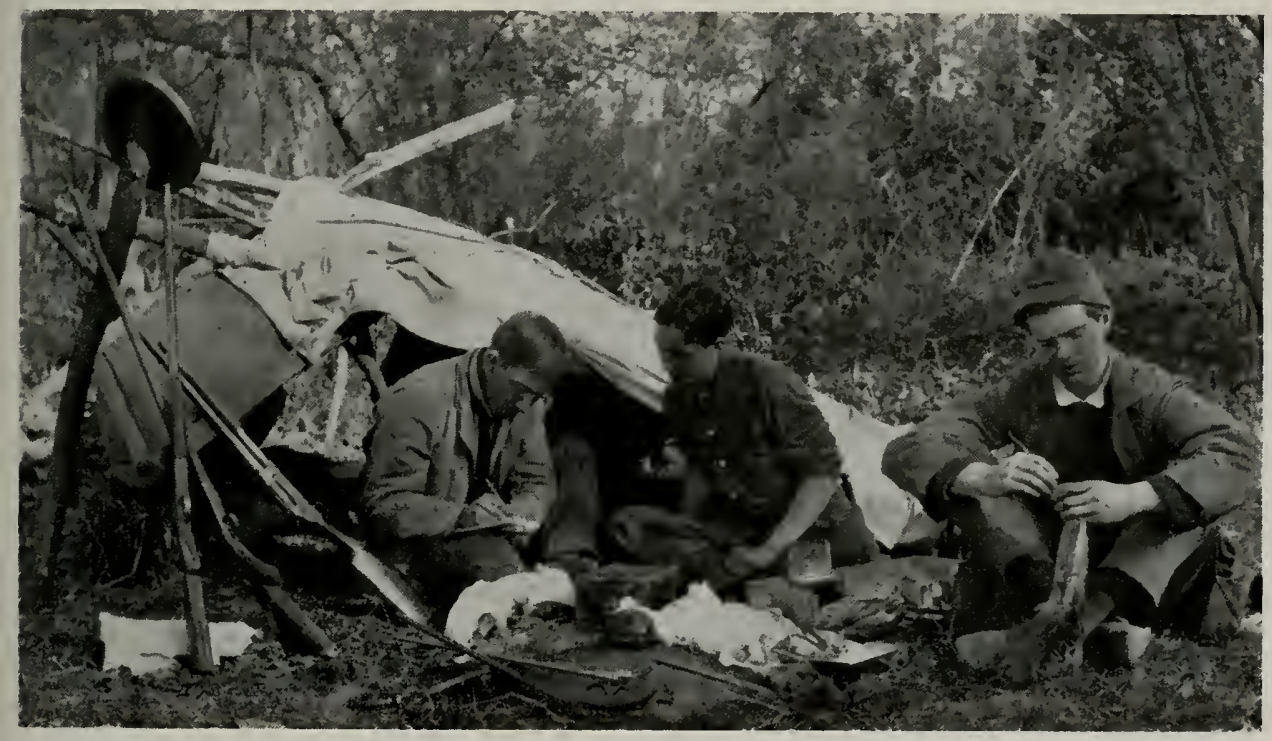

Fig. 3.-Alfred O. Gross, left, and helpers on a collecting trip near St. Joseph, Illinois, May, 1908. Gross and fellow students were studying distribution of various species of animals in Illinois. This particular field work was not part of the bird censuses of 1906, 1907 , and 1909.

censused additional acreage of certain habitats of limited area, such as marsh and orchard. WVe did this because we had encountered only a small acreage of these habitats along our regular census routes. Data from the supplementary censusing are included in tables with data from the regular censusing.

In northern Illinois, we made censuses in the two northernmost tiers of counties except Cook County. In central Illinois, we conducted censuses through Vermilion, Champaign, Ford, Piatt, De IVitt, Macon, Logan, Mason, Fulton, McDonough, and Hancock counties. In southern Illinois, we censused through Wabash, Edwards, Wayne, White, Gallatin, Hardin, Pope, Massac, Johnson, Pulaski, Alexander, Union, Jackson, Randolph, Perry, Jefferson, and Franklin counties.

The original studies by Forbes \& Gross included data on bird populations in Illi- gration is under way by mid-July, and the migration lasts until December. Therefore, we conducted most of our summer censuses between early June and mid-July and our winter censuses between early December and March 1. Having access to Dr. Gross original field notes, we were able to recalculate the 1906-1909 population densities for precisely the seasonal periods used in our censuses, thus insuring that the two sets of data were seasonally comparable. Because of the seasonal limitations and our recalculations mentioned above, our data for the Gross and Ray censuses do not correspond with datal published by Forbes \& Gross.

Population data in this paper represent summer and winter censuses of the two survers. The summer censuses were made during the following periods: in northern Illinois-June 30, July 1-3, 5-8, 1909; June 25-29, July 1-2, 1957 ; and June 
30-July t. July 10-12, 1+-15, 1958; in central Illinois-May 22-23, 27-29, 31, July 9-13, 15, 1907; June 22-26, 28-29, 1909; June 18-19. 21-2t. July 8, 10, 12. 1957 ; and June 15, 17, 23-28, July 10. 1958 ; in southern Illinois - June +-8 . 10-1+. 17-21, 25-29. July 1. 1907; June

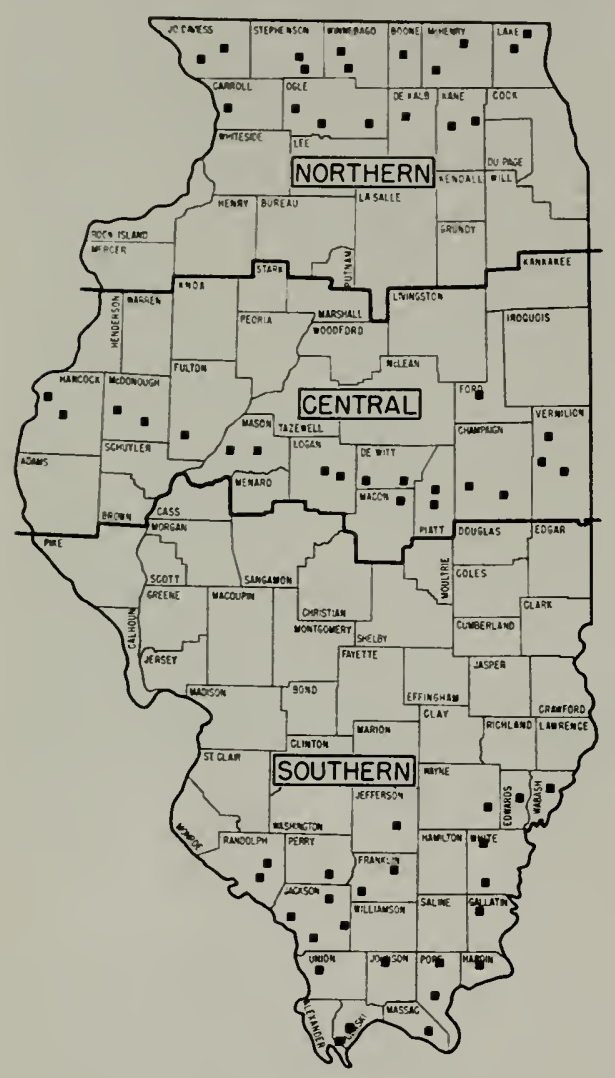

Fig. 4.-Areas (indicated by black squares) in which the strip census method of estimating bird populations was used in 1956, 1957, 1958, and 1959. In most areas, censuses were made in both summer and winter, in a few areas in only one of these seasons. The boundaries between the northern, central, and southern zones discussed in this paper are shown by heavy lines.

S-11, 1t-17, July 13-15, 1909; June 11-17, July 8-10, 1957; and June 13-14, 18-21, July 8-9, 1958.

The winter censuses were made during the following periods: in northern lllinois -December 3, 6-8, 10, 1906; January $2-5,8-11,1+-17,1907$; December +6 . 1956; January 22-23, 1957; February 27, 1958 ; in central Illinois-December 11 ,
13, 17-18, 1906; January 21-25, 27, 29-30, February 1, 1907 ; December 14, 17, 1956; February +-8, 1957 ; February $5-6,12-1+, 2+-26,1958$; in southern 1llinois - February 6-8, 9, 11-14, 18-21, 1907; December 27-28, 1956; January 8-13, 1957 ; and February 7-11, 1958.

Forbes \& Gross (1923:+36) stated that the strip census method used in their studies limited them "to birds of more or less open country." Although reduced visibility in woodlands and dense shrub habitat undouhtedly affected the accuracy of the method, data for such habitats were gathered both in the earlier field work and in our own. However, in considering the value of the method, we were concerned primarily with open-field areas. In defining habitats, we placed primary emphasis on the nature of the land cover, not on the land use. Thus, we classified a stand of alfalfa as a kind of hayfield even if it had been grazed.

Ideally, all habitats censused should be represented by comparable large-size samples, but in random strip censuses, such as were used in the recent and earlier studies, the observers covered different habitats approximately in proportion to the total acreage of each habitat in the areas censused. For certain habitats (such croplands as corn and small grain, for example) areas of several hundred acres were represented, while for some other habitats (for example, vegetable crops) only a few acres were represented. The data for habitats represented by only a few acres are probably not very significant; thus, there is a certain amount of waste in random strip censusing.

In this paper, we have summarized virtually all the field data that were collected in the summer and winter seasons in both the 1906-1909 period and the 1956-1959 period regardless of sample size, but the question of what constitutes an adequate census area deserves further consideration in order to help the reader evaluate the data.

The size of an adequate census area probably varies from habitat to habitat and season to season. In many habitats, open-field habitats especially, bird populations are much more variable in winter than in summer, and winter census areas should presumably be larger than summer 
areas. To obtain information on the relationship between the size of the census area in open fields and the measures of the bird population in such fields, we examined data on open-field bird populations from +27 summer strip counts in

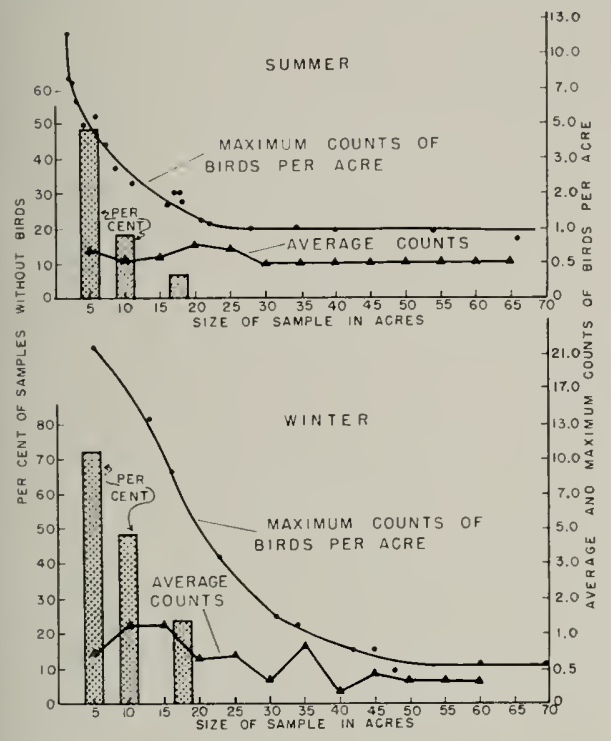

Fig. 5.-Bird population data for census areas (samples) of different sizes: (1) the per cent of the areas (samples) on which no birds were found, (2) the average numbers (average counts) of birds per acre, and (3) the maximum numbers (maximum counts) of birds per acre.

areas ranging in size from 0.3 acre to 80 acres and from 203 winter strip counts in areas ranging in size from 0.2 acre to $7+$ acres. Three measures of bird populations in these sample areas are presented in fig. 5. The three measures were (1) the per cent of areas of different sizes void of birds, (2) the maximum counts of birds per acre in areas of different sizes, and (3) the average count of birds per acre for sample areas in each size class.

In all strip census areas of 5 acres or less, about 49 per cent were void of birds in summer and 72 per cent in winter, fig. 5 . For areas of $6-10$ acres, the percentages were 19 in summer and +9 in winter, and, for areas of 11-20 acres, 7 in summer and 23 in winter. In summer, all census samples of 19 acres or more contained at least 1 bird. In winter, 17 per cent of the areas of $21-30$ acres had no birds, but all areas of 28 acres or more contained at least 1 bird.

The curves representing the maximum counts of birds per acre in areas of different sizes, fig. 5, showed greater extremes of bird populations in winter than in summer and consecpuently indicated the requirement of larger sample areas in winter. Maximum counts in plots of 5 acres or less were about 12 birds per acre in summer and 22 per acre in winter. As the size of the census plot was increased, the curve of maximum counts fell steeply (more steeply in summer than in winter), tended to level out, and attained a nearly constant level at about 25 acres in summer and 50 acres in winter.

The average counts of birds per acre in areas of different sizes showed the significance of the size of the census area. In summer samples, the mean number of birds per acre fluctuated noticeably in samples under 30 acres but was relatively constant in larger areas. In winter samples, the mean fluctuated greatly in samples under 50 acres but tended to level out for samples of larger size.

These data suggest that, when the strip census method is used, the minimum size of census areals of open-field habitat should be not less than 30 acres in summer and not less than 50 acres in winter.

In discussing results of strip censuses, Forbes (1907:308-9, 1913:37t-5) used the terms most important, most abundant, and more abumdant to designate those species of birds that togrether made up 85 per cent of a censused bird population, as, for example, the birds of a given habitat in summer. This percentage was selected arbitrarily. Because 85 per cent provides a good sample of the avifauna, we used this figure throughout the study in determining the species designated as common in the various habitats discussed. (In determining the common birds in the statewide population, we used 70 per cent, table 56 ; the number of species that together made up 85 per cent of the state population was too great to be included conveniently in a table.)

Our data on Illinois acreages of the various habitats, fig. 6 , have been derived from one or more of four principal sources: (1) published records of the U.S. Bureau of the Census (1913, 1961), (2) 
published records of the Illinois Cooperative Crop Reporting Service (Ewing 1959), (3) the published wetlands survey of the U. S. Fish and Wildlife Service (Shaw \& Fredine 1956), and (t) published records of the University of Illinois Agricultural Experiment Station (King \& Winters 1952). These sources were supplemented by unpublished records of the 1906-1909 and the 1956-1958 bird censuses.

In discussing estimates of 1 llinois bird populations, we have referred to northern, central, and southern zones of the state, fig. t. For convenience, we based these zones on auricultural districts defined by the Illinois Cooperative Crop Reporting Service (Ewing 1959, map).
In this study, the treatment of two such similar species as the eastern and the western meadowlarks, as well as the blackcapped and the Carolina chickadees, offers a problem. Because in most instances we could not make specific determinations in these groups, we have usually lumped the data for the two species under one heading, for example, meadowlark (species?) or chickadee (species?).

The basic quantitative data for this study are presented in two types of tables, the first with emphasis on statistics (example: table 4), intended only to give the reader some impression of the inherent variability in the population data presented, and the second with emphasis on avifauna (example: table 5), intended to
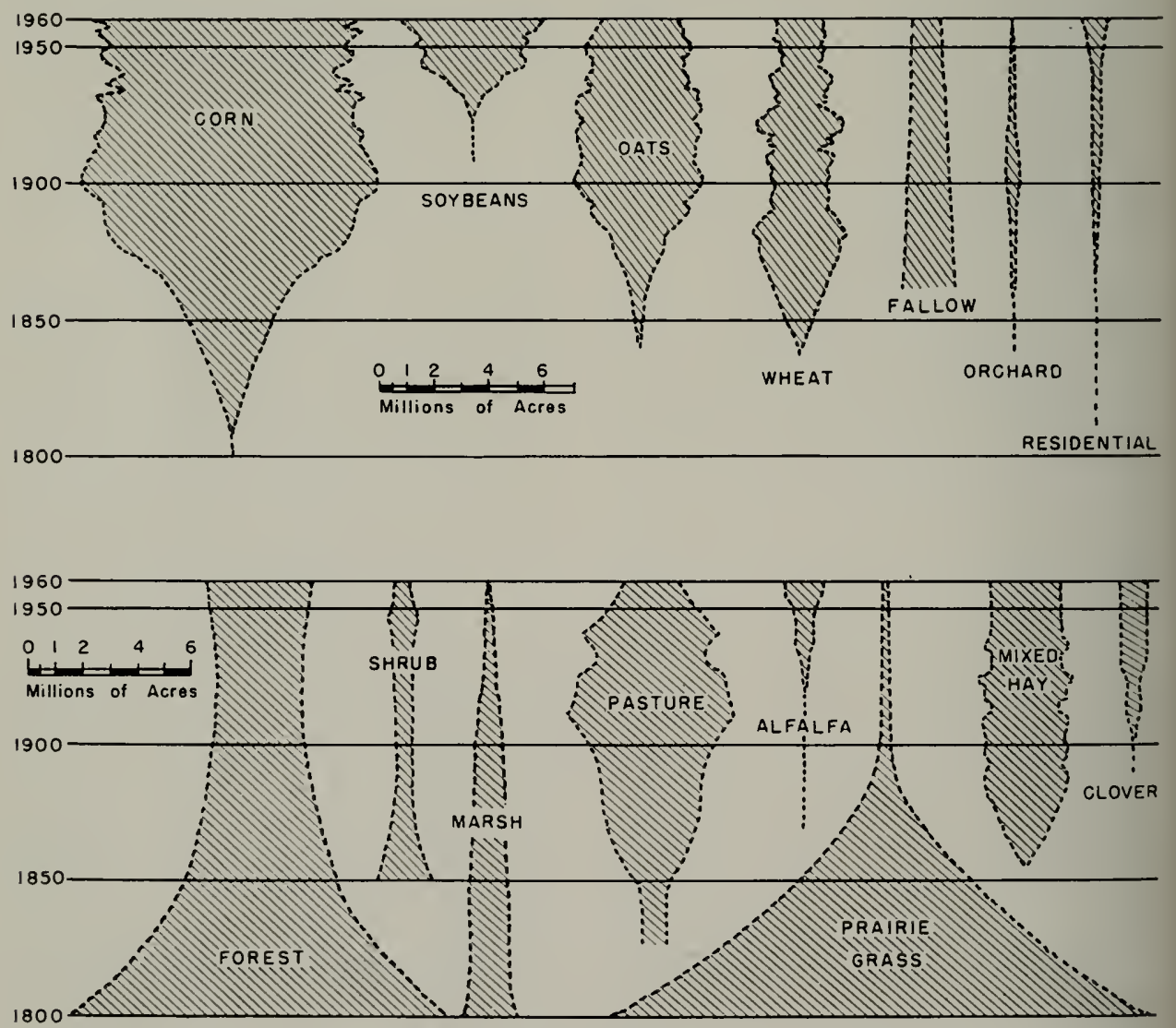

Fig. 6.- Acreage of various hird habitats in Illinois from about 1800 through the years of the hird surveys reported here. Acreage data are principally from four sources: published records of the United States Bureau of the Census, published records of the Illinois Cooperative Crop Reporting Service (Ewing 1959), published wetlands survey of the U. S. Fish and Wildlife Service (Shaw \& Fredine 1956), and publjshed records of the University of Illinois Agricultural Experiment Station (King \& Winters 1952). 
provide data on the species of birds found in each habitat. Each table of the second type is arranged with the most numerous or the most frequently encountered species at the head of the list. Species of equal frequency are listed in phylogenetic sequence according to the American Ornithologists' Union (1957). Unidentified birds and birds identified only to genus, except those in Sturmella and Parus, are listed at the end of each of these tables. A few of these tables include species that appear to be out of habitat (for example, the Canada goose listed in table $5 t$, the table for wintes forests). The census method required that birds should be counted if they were in or over the census strips in front of the observers. In the example mentioned, a small Hock of Canada geese crossed the census strip ahove some woodlands we were censusing. Thus, the ecological picture presented in this and a few other tables is somewhat distorted.

In the summer avifaunal tables for certain habitats, we have designated some species of birds as being breeding species in those hahitats. This designation means that the species were found nesting in the habitats either during the 1907-1909 or the 1957-1958 surveys.

In this publication, we have adopted the common names of birds as presented by the American Ornithologists' Union (1957). $A$ list of common and scientific names of all species encountered in the censuses appears in table 55 .

\section{Evaluation of Strip Census}

The strip census estimate of a bird population presumably has some relationship to the true population. A relatively constant relationship is all that we require of a census technique that we use to make comparisons between populations in different habitats (or different time periods). The question remains as to how closely the strip census estimate approximates the true population of birds in a given habitat. Cooke (1915:2) felt that the strip census as reported by Forbes (1908) was so radically different from the breeding-bird census that figures from the two censuses were not comparable.

In order to determine how closely the strip census method reflected the true bird population, we ran both strip censuses and breeding-bird censuses on special stud! areas and compared the results. 'The breeding-bird census technique (Stone $1950: 185-6)$ has been widely accepted as a reasonably accurate estimate of the true bird population of an area.

Our comparison of the two types of census was conducted in June, 1959, on two study plots, each a t0-acre hayfield, located 1.5 miles apart near Sibley, Illinois. One field belonged to John Ames, the other to Herbert Brucker. The study plots were measured and staked off into squares of 1.6 acres each. In these areas, we made counts of singing males in the early morning (0600 to 0800 Central Standard Time) and located as many nests as possible. During the month, we determined as closely as possible the number of birds breeding on each of the 40 acre tracts. We conducted breeding-bird counts usually every other day and on alternate days ran strip censuses across the study areas. In making the strip censuses in these fields, we followed the procedure used in censusing hayfields on our regular censuses.

IVe chose hayfields for study because they support a fairly high hird population and a varied nesting fauna, and we were interested in qualitative as well as quantitative comparison of data collected by the two methods.

The two t0-acre fields differed in avifaunal characteristics and other aspects. The Ames field was rolling and contained a higher percentage in sweet clover, while the Brucker field was flat and contained a higher percentage in red clover. The two fields harbored the same principal species of birds, though in different proportions, fig. 7. Our breeding-bird censuses indicated that the populations of birds in the Ames (area A) and the Brucker (area B) fields consisted of hobolinks, 28 and 24 per cent, respectively, of the total breedinghird population; dickcissels, 25 and 40 per cent; redwinged blackbirds, 21 and 10 per cent; grasshopper sparrows, 16 and 18 per cent; meadowlarks (Sturnella spp.). 8 per cent in each area; and Henslow's sparrows, 2 and 0 per cent. Our strip censuses showed that the populations of the two areas, $\mathrm{A}$ and $\mathrm{B}$, consisted of bobolinks, 39 and 15 per cent, respectively; dickcissels, 17 and +5 per cent; redwinged 
hlackbirds, 16 and 10 per cent; grasshopper sparrows, 16 and 22 per cent; meadowlarks, 11 and 7 per cent; and Henslow's sparrows, 2 and 0 per cent. 'Though the strip censuses did not show the population characteristics precisely, they clearly reflected the differences between the two fields and provided a reasonably accurate qualitative picture of the populations.

Quantitatively, populations of the two fields differed markedly, as shown by both the breeding-hird and the strip censuses.
The population density of passerine birds, as indicated by the breeding-bird censuses, was 4.6 nesting birds per acre for area $\mathrm{A}$ and 2.6 for area B. The density, as indicated by the strip censuses, was 4.5 nesting birds per acre for area $A$ and 2.9 for area $B$.

The closeness of the two sets of figures is surprising because of the difference in potential between a breeding-bird census and a strip census. In a breeding-bird census, in which a high percentage of the nests in an area are located, the researcher
AREA A

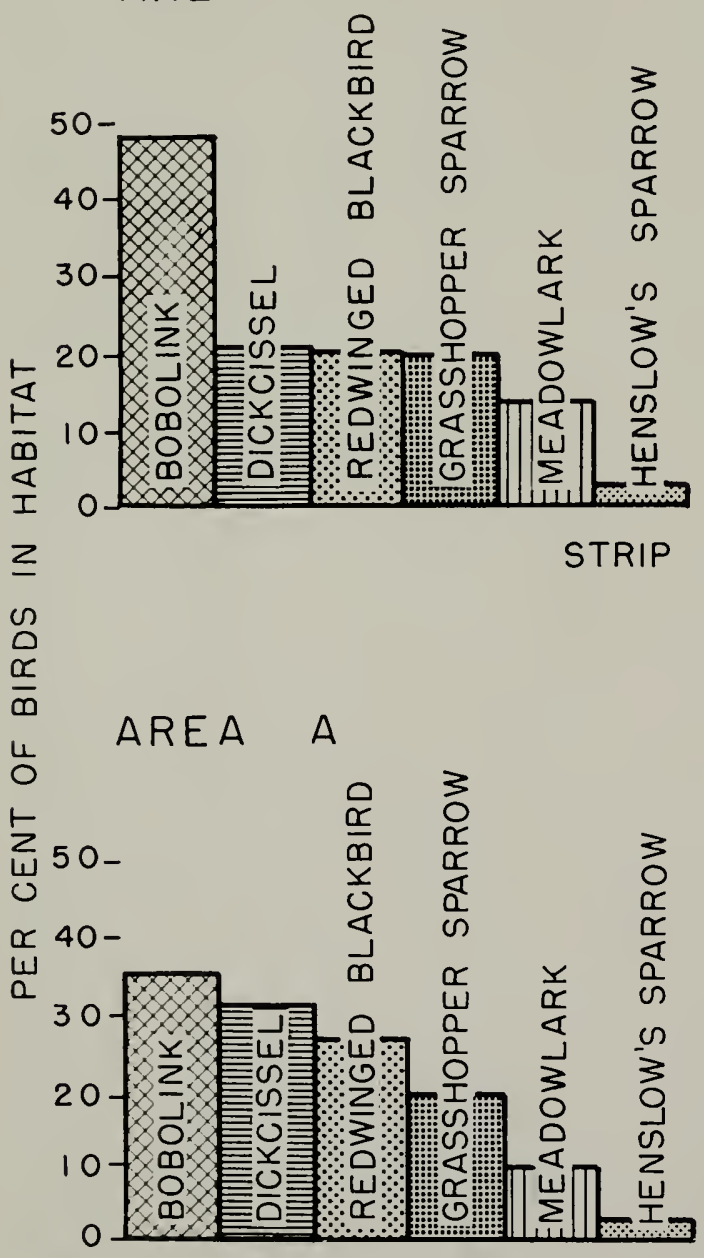

AREA B

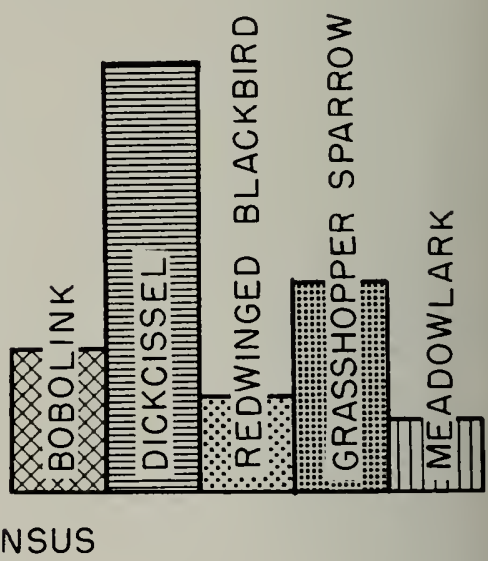

AREA B

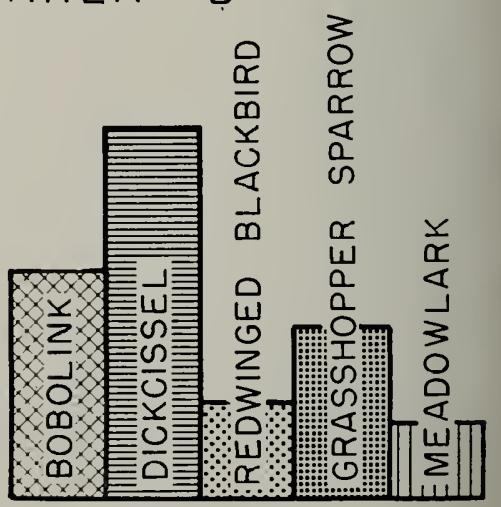

\section{BREEDING-BIRD CENSUS}

Fig. 7.-Species composition of the nesting avifauna (excluding game birds) of two t0-acre hayfields (areas A and B) as determined by two types of census, the breeding bird census and the strip census. The histograms show the per cent each species comprised of all birds counted in each habitat. 
obtains a close approximation of the true population density, including both males and females of each species. In the strip

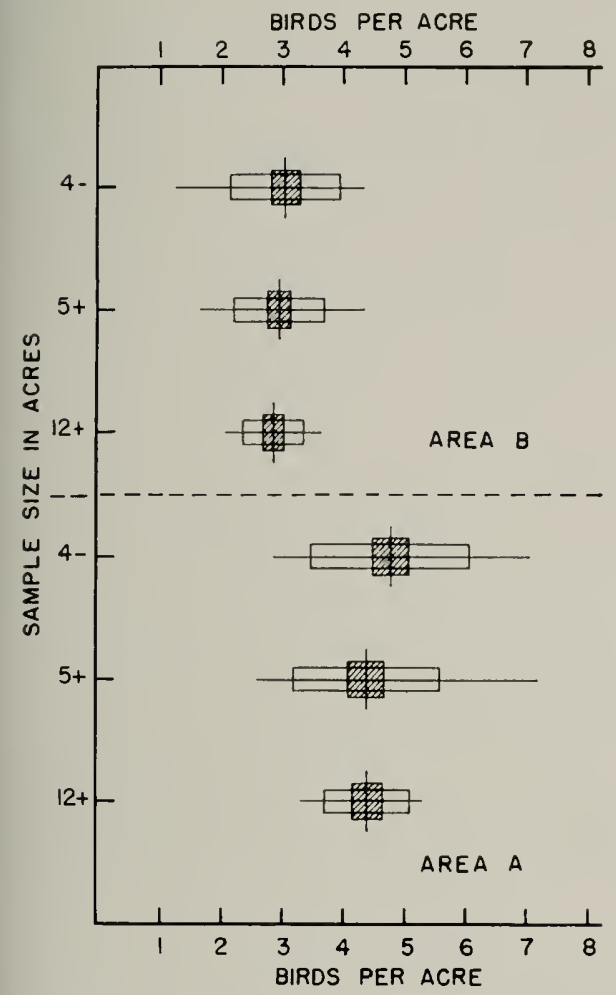

Fig. 8.-Populations of nongame birds in census areas of different sizes. The populations were estimated by strip censusing in two hayfields, areas $A$ and B. Strip census areas (samples) were categorized by size ( $t$ acres or less, 5 acres to 9 acres inclusive, 12 acres or more); each sample area represented $1+$ censuses conducted between June + and 21 , $1959(0600-1200$ CST $)$. The horizontal line through each open box represents the range of variation in the measure of the bird population; the vertical line represents the mean population based on 14 censuses. Each open box represents one standard deviation each side of the mean, and each shaded box represents one standard error each side of the mean.

census, on the other hand, some females (especially incubating females) are probably overlooked, and, consequently, we might suppose the density indicated by a strip census to be less than the density indicated by a breeding-bird census. The figures on density presented above do not bear out this supposition. 'To some extent the similarity in density figures is brought about by the behavior of the breeding males. There is a tendency for males of many species to approach the census strip and enter or cross it. This behavior may represent curiosity or aggressiveness toward an intruder; it has the effect of exaggerating the count of males per unit of area. By chance, this mechanism appears to compensate for the low count of females during the incubation season.

Variations in the strip census estimates of bird populations on the two special study areas are shown in fig. 8 . The range of density values tended to decrease in strip census data as the size of the area censused increased, fig. 8. When the area censused was + acres or less, density values for the Ames area ranged from 2.9 to 7.1 birds per acre on different census trips, while the values for areas of 12 acres or more ranged from 3.3 to 5.3 . For the Brucker area, comparable values were 1.3 to.++ birds per acre ( 4 acres or less) and 2.1 to 3.7 birds per acre (12 acres or more).

The data for population densities presented above apply to nesting passerine birds only. Besides these passerines, there was a high population of pheasants in the Sibley area in which the Ames and Brucker fields were located. Ronald F. Labisky of the Illinois Natural History Survey, who has made intensive studies of the pheasant population in the Sibley area, reported that during the 1959 breeding season about 1.3 pheasant nests were established per acre of hayfield. Neither the breeding-bird census nor the strip census indicated a density of this magnitude for pheasants. The breeding-bird census indicated a pheasant population of 0.07 nest per acre on area $A$ and 0.12 per acre on area $B$. The strip census indicated a population of 0.05 pheasant per acre on area $A$ and 0.02 per acre on area $B$.

Obviously, the strip census method is much less reliable for estimating pheasant populations than for estimating populations of the more conspicuous passerines.

Cooke (1915:2) pointed out that the number of birds per square mile in southern Illinois in June, 1907, as reported by Forbes (1908), was less than half the average for the national (breeding-bird) census; Forbes based his figures on strip censuses. The population data in our paper 
are of value primarily for comparisons within this study, and the reader should recognize the specialized nature of the data.

The greater variation of bird populations in winter than in summer has already been mentioned. It is difficult to determine to what degree the strip census estimates reflect the true winter population. In winter, birds are not so evenly distributed as in summer and they are less restricted to definite territories. These conditions decrease the accuracy of censusing, regardless of the method used. The great variation in population data from four strip censuses in each of two areas in winter is shown in tables 1 and 2. Total population densities as indicated by the strip censuses varied from 10 to 107 birds per 100 acres in the cornfield and from 35 to 215 birds per 100 acres in the woodland.

Only 1 of the 5 species recorded in the cornfield habitat was found on all four census trips, and only 2 species were found on at least three census trips. In the woodland habitat, only 2 of 16 species of hirds were found on all four census trips, only + species on at least three censuses, and 12 species on at least two censuses. Ad-

Table I.-Bird populations of a central Illinois cornfield in the winter of 1958-59 as determined by 40 -acre strip censuses on four dates.

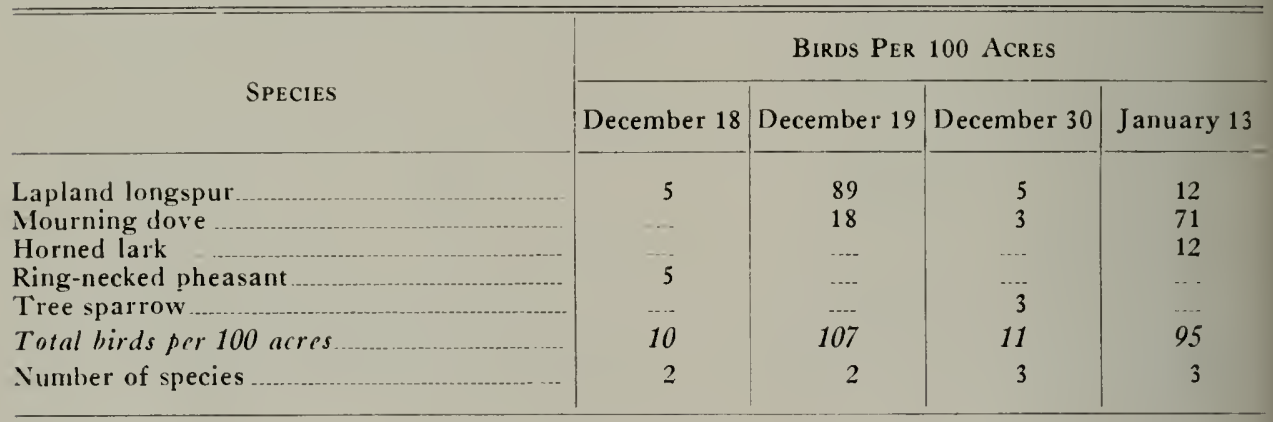

Table 2.-Bird populations of a central lllinois woodland in the winter of 1958-59 as determined by $\mathbf{2 0}$-acre strip censuses on four dates.

\begin{tabular}{|c|c|c|c|c|}
\hline \multirow{2}{*}{ SPECIES } & \multicolumn{4}{|c|}{ Birds Per 100 Acres } \\
\hline & December 5 & December 19 & December 29 & January 13 \\
\hline Downy woodpecker & 30 & 5 & 15 & \\
\hline Red-bellied woodpecker & 15 & 15 & 5 & 5 \\
\hline Tufted titmouse & 37 & 10 & & \\
\hline Common crow & & & 30 & 5 \\
\hline Chickadee (species?) & 30 & 5 & -.-- & $\ldots$ \\
\hline Brown creeper & 22 & 5 & 5 & $\ldots$ \\
\hline $\begin{array}{l}\text { Yellow-shafted ficker } \\
\text { Slate-colored junco }\end{array}$ & $\begin{array}{l}22 \\
22\end{array}$ & $\ldots$ & 5 & $-\cdots$ \\
\hline Blue jay & $\ldots$ & 5 & 20 & \\
\hline Hairy woodpecker & & & 15 & 10 \\
\hline Cardinal & 7 & 5 & 5 & 5 \\
\hline Eastern bluebird & 15 & & & $\ldots$ \\
\hline White-breasted nuthatch & & 5 & 5 & .... \\
\hline Golden-crowned kinglet & & 10 & & $\cdots$ \\
\hline Tree sparrow & $\cdots-$ & $\therefore=$ & 10 & $\ldots$ \\
\hline $\begin{array}{l}\text { Carolina wren } \\
\text { Dendrocopos (species?) }\end{array}$ & $\ldots$ & $\cdots$. & 10 & $\begin{array}{c}5 \\
\cdots\end{array}$ \\
\hline Unidentified bird ......... & 15 & & 5 & .... \\
\hline Total birds per 100 acres & 215 & 65 & 130 & 35 \\
\hline Number of species & 9 & 9 & 10 & 5 \\
\hline
\end{tabular}


mittedly, the sample census areas, +0 acres for open field and 20 acres for woods, were small for winter censusing.

The high variability shown in our winter census data appeared to be more a characteristic of winter bird populations than a defect of the census method. Regardless of its source, high variability makes interpretation of winter data more difficult and probably less reliable than interpretation of summer data.

That bird populations of an area may fluctuate greatly from year to year is well recognized. Data presented by Kendeigh $(19+4: 93-t)$ showed that the number of breeding birds in a 55-acre forest in east central Illinois fluctuated (increased or decreased) from one year to the next an average of 23 per cent (average of differences between consecutive spring populations) in 11 years. The minimum difference (increase or decrease) between populations in consecutive years was 5 per cent and the maximum $+t$ per cent. Fluctuations for particular species were even greater; the red-eyed vireo population changed from 0 in $19+0$ to 13 pairs in $19+1$, and the number of house wrens increased from 10 pairs in 1940 to 20 pairs in 19+1. Year-to-year fluctuations in winter populations were even greater than in spring populations, averaging +6 per cent (average of differences between consecutive winter populations) for $1+$ years. The minimum difference (increase or decrease) between consecutive winter populations was $t$ per cent and the maximum 133 per cent.

Bird populations in open-field habitats are probably as variable as in forests. Data presented by Mrs. H. A. Baker (19551961 ) indicated that the number of breeding birds on 16 acres of havfield and pastureland in central Indiana fluctuated from year to year, over a 7-year period, by 23 per cent (average of percentage differences between consecutive summer populations). This is the year-to-year fluctuation percentage shown in Kendeigh's summer forest populations.

Year-to-year fluctuations greatly complicate interpretation of our census data, representing as they do only + years in 50 . Our conclusions on the subject of population changes rely to some extent on other sources of history ; they must be considered tentative and always open to reinterpretation.

\section{WEATHER PATTERNS OF CENSUS YEARS}

The weather conditions that preceded and accompanied the two census periods are worthy of consideration, even though the effect of weather on bird populations is difficult to evaluate. Most of the birds that breed in Illinois spend a large part of the year well to the south of this state, and most of the species that remain through the year are adapted to survive the rigors of Illinois winters.

Available data indicate that adult passerine birds have a strong tendency to home to the same nesting area year after year. This behavior probably helps to reduce population fluctuations in a given geographic area. Population stability depends, of course, partly on survival of adult birds. Some species, such as the eastern bluebird, are known to suffer large population losses during severe winters.

In trying to evaluate the possible effect of weather on the bird populations of lllinois, we should consider both the general weather patterns and the extreme conditions that may have affected bird survival.

No prolonged period of adverse weather (excessive precipitation or extremes of temperature) occurred between 1899 and January, 190t. But unusually low temperatures in January, February, and April, 1904 , may have had an adverse effect on bird populations, particularly of earlynesting species. Record-breaking cold occurred in February, 1905, but it did not endure for long and probably had little effect on bird populations. Precipitation was not unusual in any of these years. It seems doubtful if weather factors (even the cool spring of 1904) in the years leading up to the 1906-1909 surveys had any widespread effect on the bird populations censused in these surveys. Temperature and precipitation patterns in the survey years themselves, figs. 9 and 10 , were probably more important.

The winter of 1906-07 was comparatively warm and moderately rainy, but the following spring and summer months were extremely cold, the coldest at least since 1878, and the cold, especially that in April and May, could have had a notable effect 
on the state bird population. The census data indicate that the 1907 breeding population of birds in Illinois was conspicuously lower than the population of 1909 , a normal year in terms of weather. The fact that many species had low populations in 1907 will be mentioned repeatedly in the following text, and the reader should bear in mind that the adverse spring weather of 1907 may have played a role in this depression. The winter of 1908-09 was mild, the following spring and sum1906

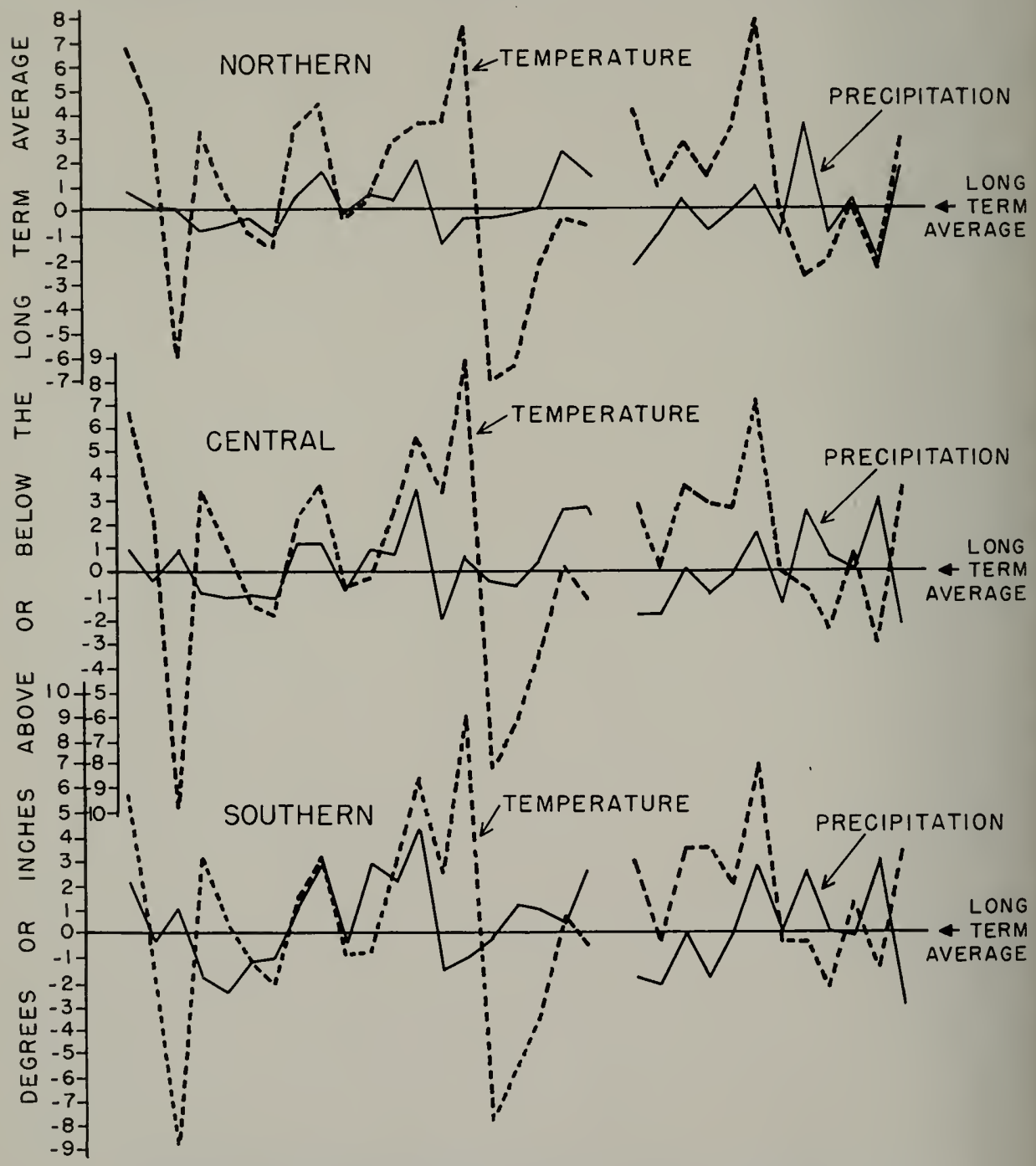

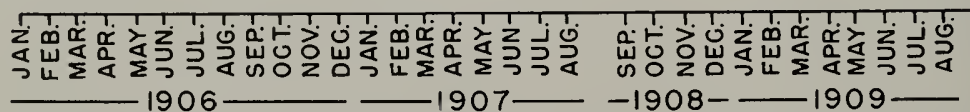

Fig. 9.-Temperature and precipitation deviations from the long-term averages in the northern, central, and southern zones of Illinois during and immediately preceding the years of the bird surveys of 1906-1909. 
mer were near normal in terms of weather, and the 1909 level of the breeding population of birds in Illinois was well above the 1907 level. Bird populations are usually quick to recover from a depression.

Weather in the years from 1952 to the beginning of the second bird survey (1956) was marked by drought, but it 1956

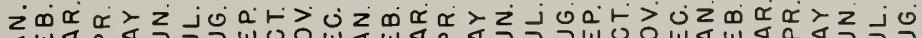

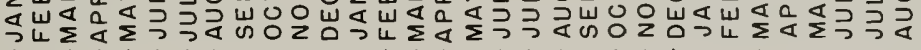

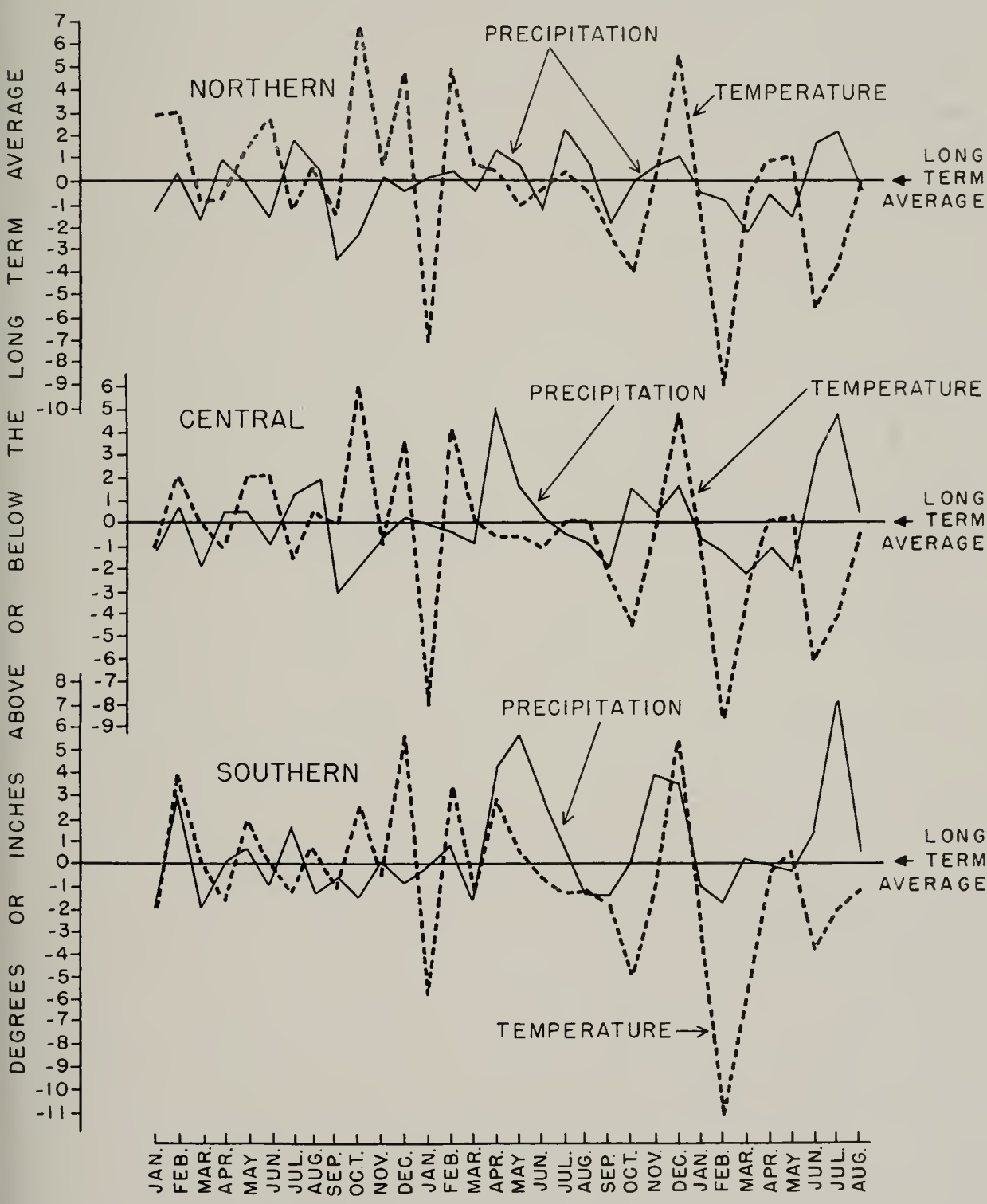

Fig. 10.-Temperature and precipitation deviations from the long-term averages in the northern, central, and southern zones of Illinois during and immediately preceding the years of the bird surveys of 1956-1958. 
was not unusual otherwise. We do not know what effect low precipitation hat on hird populations, but by 1956 the precipitation level was coming back to normal, and we judge that the dryness of the earlier years prohably had little effect on the hird populations surveyed.

The census years of 1956-1958 showed a variable weather picture, fig. 10 , with temperature and precipitation Huctuating to about the same degree as in 1906-1909. The winter of 1956-57 in lllinois was relatively warm (except in January) and precipitation was normal; the following sprimg and summer were about normal in temperature and normal or above normal in precipitation. No known weather conditions in this year would have had any special effect on bird populations in the state. 'The start of the winter of 1957-58 was mild, and precipitation continued to he normal, but Fehruary and March were very cold. 'The cold may have depressed populations of at least a few species of birds. The late part of the following spring was warm, but the summer was cool and wet. 'The summer conditions may have lad an adverse effect on production of young birds, but the adult population, with which we were primarily concerned, was probably not greatly affected. Our census data show that the state population of nesting birds was about the same in 1958 as in 1957 and tend to support the view that the early spring cold in 1958 had no general depressing effect on the state bird population.

The years 1909, 1957, and 1958 in 11linois were probably similar to each other in terms of weather and its effect on bird populations. The 1907 bird population was depressed, and weather probably had a bearing on this depression.

\section{BIRD POPULATIONS IN SUMMER HABITATS}

Between the dates of May 22 and July $15,14,4+7$ acres were covered by strip censuses, 7,662 acres in 1907-1909 and 6,785 in 1957-1958. Acreages of the different habitats censused in the two study periods combined ranged from 4,003 acres of corn to 1 acre of sugar cane. Because it is pointless to discuss bird populations in habitats represented by only small acreages, we have disregarded habitats represented by less than 50 acres. In table 3 are listed the summer habitats discussed in

Table 3.-Acreages of habitats covered by summer strip censuses in the three zones of lllinois, 1907-1909 and 1957-1958.

\begin{tabular}{|c|c|c|c|c|c|c|c|}
\hline \multirow[b]{2}{*}{ TYPE OF HABITAT } & \multicolumn{2}{|c|}{ Northern Zone } & \multicolumn{2}{|c|}{ Central Zone } & \multicolumn{2}{|c|}{ SOUTHERN ZONE } & \multirow[b]{2}{*}{ Тотан. } \\
\hline & $\begin{array}{c}1907- \\
1909\end{array}$ & $\begin{array}{c}1957- \\
1958\end{array}$ & $\begin{array}{c}1907- \\
1909\end{array}$ & $\begin{array}{c}1957- \\
1958\end{array}$ & $\begin{array}{c}1907- \\
1909\end{array}$ & $\begin{array}{c}1957- \\
1958\end{array}$ & \\
\hline Corn (all types) & 353 & 616 & 1,159 & 629 & 987 & 259 &,+ 003 \\
\hline 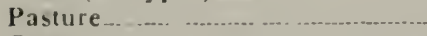 & 193 & 279 & +42 & 171 & 882 & 120 & 2,087 \\
\hline Oats & $2+1$ & 166 & 596 & 123 & 183 & 10 & 1,319 \\
\hline Mixed hay (including mosved). & 175 & 212 & 125 & 89 & $53+$ & 77 & 1,212 \\
\hline Forest (all types) & 2 & 177 & 16 & 214 & 60 & 340 & 809 \\
\hline Soybeans & $\ldots$ & 167 & $\ldots$ & +89 & .... & 121 & 777 \\
\hline Wheat (including shocked). & 6 & 16 & 169 & 63 & 381 & 138 & 773 \\
\hline Fallow fields $\ldots \ldots \ldots$ & $2+$ & 48 & 24 & 37 & 319 & 230 & 682 \\
\hline Red clover & 11 & 110 & 46 & 90 & 104 & 85 & $4+6$ \\
\hline Residential areas $\ldots \ldots$ & 11 & 160 & 8 & 75 & 35 & 98 & 387 \\
\hline Plowed ground. & 3 & 20 & 11 & 28 & 134 & 139 & 335 \\
\hline All shrub and hedge & 4 & 47 & 3 & 70 & 56 & 151 & 331 \\
\hline Ungrazed grass & 15 & 96 & 1 & 49 & 41 & 88 & 290 \\
\hline Alfalfa & 2 & 138 & 7 & 41 & $\ldots$ & 49 & 237 \\
\hline Orchard & & 36 & 6 & 7 & 45 & 78 & 172 \\
\hline Marsh _........... & 19 & 90 & 3 & 1 & 26 & 16 & 155 \\
\hline Garden crops & 40 & 5 & 20 & 1 & 45 & $\cdots$ & 111 \\
\hline Small grain stubble ............. &.- & 3 & 1 & 13 & 1 & 76 & 94 \\
\hline Sweet clover & & 26 & . & 25 & 1 & 5 & 57 \\
\hline Barley and rye. & 18 & - & 2 & $\ldots$ & 14 & $\ldots$ & 34 \\
\hline Total & 1,117 & 2,412 & 2,639 & 2,215 & 3,848 & 2,080 & 14,311 \\
\hline
\end{tabular}


this paper and the acreages covered by the strip censuses.

Population data in both tables and text refer to supposedly adult birds. Juvenile birds were counted during the censuses, but, in order to eliminate a source of variability, we did not include obviously juvenile birds in population calculations.

\section{Cornfields (Summer)}

In terms of acreage, corn is the principal crop of Illinois. The cornfield habitat comprised almost 28 per cent $(t, 003$ acres) of the land censused in the summers of 1907-1909 and 1957-1958, table 3 . From the data sources mentioned previously, we calculated that corn acreage declined from about $10,400,000$ acres in 1907 to $8,400,000$ in 1957. Practices in corn culture have changed, but the characteristics of cornfields at the time of year the censuses were made have remained the same, fig. 11. At this season, the young plants in widely spaced rows (about 40 inches apart) usually varied in height from 3 or $t$ inches to 2 feet, though some fields with plants over 3 feet in height were censused. The dominating feature of the cornfield habitat in early summer is bare ground.

Quantitatively, corn is poor bird habitat, figs. 22-24. Mean numbers of birds per acre in corn for all census years in the three zones of the state in summers varied from 0.3 to 0.9 , and the extreme variation for consecutive census years was 0.7 to 0.3 in 1957 and 1958 , table $t$. Population densities were consistently higher in the northern zone than in other parts of the state. Also, they tended to be higher in the later than in the early census years, but the extreme annual variations preclude any precise conclusion on changes, between 1906 and 1958, in density of bird populations in cornfields of the state. Though there was no conclusive evidence of a general quantitative change in total bird population, the composition of the avifauna had altered.

At least 60 species of birds were recorded in summer cornfields in the two study periods combined; this figure probably reflects the large acreage covered more than it does the quality of the habitat. The complete list of species, with population figures for each, is presented in table 5. Only 5 of the species (horned lark, grackle, house sparrow, mourning dove, and redwinged hlackbird) were recorded in this habitat in all years and all zones.

The number of common species (those comprising 85 per cent of the population) in summer cornfields was higher in 1907

Table 4.-Statistical data on summer bird populations in Illinois cornfields as determined by strip censuses in the three zones. Data are (1) from all cornfields censused and (2) from sample areas (each 10 acres or more) in these fields.

\begin{tabular}{|c|c|c|c|c|c|c|c|c|}
\hline \multirow{3}{*}{$\begin{array}{l}\text { ZONE } \\
\text { AND } \\
\text { YEAR }\end{array}$} & \multicolumn{2}{|c|}{$\begin{array}{c}\text { All Cornfields } \\
\text { Censused }\end{array}$} & \multicolumn{6}{|c|}{ SAMPLE AREAS } \\
\hline & \multirow[b]{2}{*}{ Acres } & \multirow[b]{2}{*}{$\begin{array}{c}\text { Birds Per } \\
\text { Acre }\end{array}$} & \multirow[b]{2}{*}{ Number } & \multicolumn{5}{|c|}{ Birds Per Acre } \\
\hline & & & & Range & Mean & $\begin{array}{l}\text { Standard } \\
\text { Deviation }\end{array}$ & $\begin{array}{c}\text { Standard } \\
\text { Error }\end{array}$ & $\begin{array}{l}\text { Mean } \pm \\
2 \text { S.E. }\end{array}$ \\
\hline \multicolumn{9}{|l|}{ Northern } \\
\hline 1909 & 351 & 0.6 & 8 & $0.3-0.8$ & 0.6 & 0.2 & 0.1 & $0.4-0.8$ \\
\hline 1957 & 317 & 0.9 & 11 & $0.2-1.5$ & 0.8 & 0.4 & 0.1 & $0.6-1.0$ \\
\hline 1958 & 299 & 0.9 & 6 & $0.0-2.4$ & 1.0 & -.. & .... & -..- \\
\hline \multicolumn{9}{|l|}{ Central } \\
\hline 1907 & 668 & 0.3 & 11 & $0.1-1.0$ & 0.3 & 0.2 & 0.1 & $0.1-0.5$ \\
\hline 1909 & +88 & 0.5 & 7 & $0.2-0.7$ & 0.4 & $\ldots$ & ... & $=0$ \\
\hline 1957 & 328 & 0.7 & 13 & $0.2-1.5$ & 0.7 & $0 . t$ & 0.1 & $0.5-0.9$ \\
\hline 1958 & 290 & 0.3 & 5 & $0.0-0.4$ & 0.2 & ...- & -..- &..- \\
\hline \multicolumn{9}{|l|}{ Southern } \\
\hline 1907 & 550 & 0.4 & 19 & $0.0-0.8$ & 0.4 & 0.2 & 0.1 & $0.2-0.6$ \\
\hline 1909 & +33 & 0.7 & 11 & $0.3-1.5$ & 0.7 & 0.3 & 0.1 & $0.5-0.9$ \\
\hline 1957 & 103 & 0.5 & 1 & & 0.3 & & & \\
\hline 1958 & 156 & 0.7 & 10 & $0.0-1.7$ & 0.7 & 0.5 & 0.2 & $0.3-1.1$ \\
\hline
\end{tabular}


Table 5.-Summer avifauna in Illinois cornfields (birds per I00 acres) as determined by strip censuses in the three zones. Figures in parentheses indicate number of acres censused; + indicates less than 1 bird per 100 acres: * indicates breeding species in this habitat.

\begin{tabular}{|c|c|c|c|c|c|c|c|c|c|c|c|}
\hline \multirow[b]{2}{*}{ SPECIES } & \multicolumn{3}{|c|}{ Northers Zone } & \multicolumn{4}{|c|}{ Central Zone } & \multicolumn{4}{|c|}{ SOUTHERN ZONE } \\
\hline & $\begin{array}{c}1909 \\
(351)\end{array}$ & $\begin{array}{l}1957 \\
(317)\end{array}$ & $\begin{array}{c}1958 \\
(299)\end{array}$ & $\begin{array}{c}1907 \\
(668)\end{array}$ & $\begin{array}{c}1909 \\
(+88)\end{array}$ & $\begin{array}{c}1957 \\
(328)\end{array}$ & $\begin{array}{c}1958 \\
(290)\end{array}$ & $\begin{array}{c}1907 \\
(550)\end{array}$ & $\begin{array}{l}1909 \\
(+33)\end{array}$ & $\begin{array}{c}1957 \\
(103)\end{array}$ & $\begin{array}{c}1958 \\
(156)\end{array}$ \\
\hline${ }^{*}$ Horned lark & 10 & 27 & 39 & 7 & 5 & +3 & 20 & 2 & + & 8 & 3 \\
\hline Common grackle & 13 & 6 & 13 & 5 & 11 & 7 & 3 & 5 & 7 & 5 & + \\
\hline House sparrow & 8 & 8 & 1 & + & 6 & 8 & 2 & 1 & 6 & 2 & 6 \\
\hline Mourning dove & 2 & 3 & 5 & 1 & 5 & + & 1 & 7 & 6 & 1 & 6 \\
\hline $\begin{array}{l}\text { Redwinged black- } \\
\text { bird }\end{array}$ & 3 & 9 & 6 & 1 & 2 & 1 & + & 1 & 1 & 7 & 5 \\
\hline $\begin{array}{c}\text { Meadowlark } \\
\text { (species?) }\end{array}$ & 1 & 3 & + & 2 & + & 1 & + & 2 & + & & 8 \\
\hline $\begin{array}{l}\text { *ildeer } \\
\text { Brown-headed }\end{array}$ & & 2 & 2 & 1 & & + & & 2 & 8 & 3 & 5 \\
\hline $\begin{array}{l}\text { cowbird } \\
\text { Starling }\end{array}$ & 1 & $\begin{array}{l}5 \\
+\end{array}$ & $\begin{array}{l}1 \\
2\end{array}$ & + & 1 & $\begin{array}{l}\cdots-. \\
\cdots-.\end{array}$ & + & 3 & 3 & $\begin{array}{l}6 \\
1\end{array}$ & $\begin{array}{r}1 \\
13\end{array}$ \\
\hline Barn swallow & 1 & + & 1 & + & & 2 & 1 & & + & 3 & 7 \\
\hline Robin & 2 & 3 & 1 & 1 & 1 & .... & + & 2 & 3 & .... & $\ldots$ \\
\hline Common crow... & 2 & & + & 2 & 3 & $\ldots-$. & & & 1 & $\ldots$ & + \\
\hline *Vesper sparrow. & + & 6 & 1 & + & 1 & + & & & & & ..... \\
\hline $\begin{array}{l}\text { Brown thrasher } \\
\text { Yellow-shafted }\end{array}$ & + & + & & 1 & 3 & -..- & 1 & 2 & 2 & 2 & $\cdots$ \\
\hline Hicker & 3 & 1 & + & 1 & 2 & + & . & 1 & 1 & $\ldots$ & $\cdots$ \\
\hline Eastern kingbird & 2 & + & + & + & + & & + & 1 & 3 & 1 & 1 \\
\hline $\begin{array}{l}\text { Field sparrow } \\
\text { American rold- }\end{array}$ & 1 & 1 & - & + & + & 1 & + & 1 & 2 & 1 & 1 \\
\hline finch & 2 & 1 & 2 & + & 1 & & + & 1 & + & & 1 \\
\hline Dickcissel & + & 1 & 1 & 1 & + & 1 & + & & & 1 & 1 \\
\hline Indigo bunting & + & + & + & + & + & $\ldots$ & + & + & 1 & 1 & 1 \\
\hline $\begin{array}{l}\text { Mockingbird } \\
\text { Red-headed }\end{array}$ & $\ldots$ & $\ldots$ & . & $\ldots$ & - & --- & $\ldots$ & 1 & + & 1 & ... \\
\hline $\begin{array}{l}\text { wood pecker } \\
\text { Upland plover }\end{array}$ & + & $\begin{array}{l}+ \\
.\end{array}$ & 1 & + & $\begin{array}{l}1 \\
1\end{array}$ & 1 & $\cdots$ & $\begin{array}{r}1 \\
+\end{array}$ & $\begin{array}{l}3 \\
1\end{array}$ & $\cdots$ & $\cdots$ \\
\hline $\begin{array}{l}\text { Chimney swift } \\
\text { Lark sparrow }\end{array}$ & 1 & $\cdots$ & $\cdots$ & + & $\begin{array}{r}1 \\
+\end{array}$ & 1 & $\begin{array}{l}1 \\
1\end{array}$ & $\begin{array}{l}+ \\
+ \\
1\end{array}$ & 3 & -... & 1 \\
\hline $\begin{array}{l}\text { Loggerhead } \\
\text { shrike }\end{array}$ & 1 & & + & 1 & + & 1 & .... & + & 1 & $\cdots$ & \\
\hline $\begin{array}{l}\text { Blue jay } \\
\text { Bobwhite }\end{array}$ & 1 & + & + & + & + & $\ldots$ & $\cdots$ & + & 1 & $\ldots$ & -... \\
\hline $\begin{array}{l}\text { Bobwhite } \\
\text { Eastern bluebird }\end{array}$ & - & + & $\cdots$ & + & + & + & $\cdots$ & 1 & 1 & 2 & $\ldots$ \\
\hline $\begin{array}{l}\text { Eastern bluebird } \\
\text { Sparrow hawk. }\end{array}$ & - & $\cdots$ & $\cdots$. & + & 1 & & + & $\begin{array}{l}1 \\
1\end{array}$ & $\frac{2}{1}$ & 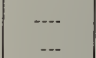 & $\begin{array}{l}\cdots-. \\
\cdots\end{array}$ \\
\hline $\begin{array}{l}\text { Cardinal } \\
\text { Catbird }\end{array}$ & + & $\ldots$. & $-\ldots$ & + & ... & + & $\ldots$ & + & 1 & $\ldots$ & 1 \\
\hline $\begin{array}{l}\text { Ring-necked } \\
\text { pheasant }\end{array}$ & & & & & & 2 & .... & & & 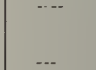 & \\
\hline $\begin{array}{l}\text { Spotted sandpiper } \\
\text { Purple martin. }\end{array}$ & $\cdots$ & & $\begin{array}{r}1 \\
+\end{array}$ & + & $\ldots$ & -..- & -... & $\begin{array}{l}. . \\
\ldots\end{array}$ & $+t_{1}$ & -... & $\ldots$ \\
\hline Bobolink & $\stackrel{+}{i}$ & 1 & + & & 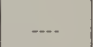 & .... & $\ldots$ & $\ldots$. & & -... & $\ldots$ \\
\hline $\begin{array}{l}\text { Yellowthroat } \\
\text { Turkey vulture }\end{array}$ & + & & $\cdots$ & + & $\ldots$ & $\cdots$ & ...- & + & + & $\because$ & $\ldots$ \\
\hline $\begin{array}{l}\text { Eastern phoebe } \\
\text { Chipping sparrow }\end{array}$ & & & 1 & & (-..- & $\cdots \cdot-$ & $\cdots$ & \pm & .... & 1 & \\
\hline Orchard oriole & & $\ldots$ & & + & $\ldots$ & $\ldots$ & -..- & + & + & $\cdots$ & \\
\hline $\begin{array}{l}\text { Greater prairie } \\
\text { chicken }\end{array}$ & 1 & & & & & & ...-. & --. & & ..... & \\
\hline $\begin{array}{l}\text { Brewer's black- } \\
\text { bird }\end{array}$ & & & 1 & & & & - & & & & \\
\hline $\begin{array}{l}\text { Traill's Aycatcher } \\
\text { Rufous-sided }\end{array}$ & 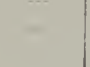 & ..... & & + & -..- & --- & --. & + & $\cdots$ & -... & $\ldots$ \\
\hline towhee. & & .. & & & -..- & ...- & $\cdots$. & + & + & $\ldots$ & $\ldots$ \\
\hline
\end{tabular}


October, 1963 Graber \& Graber: Bird Populations in Illinois

Table 5.-Continued

\begin{tabular}{|c|c|c|c|c|c|c|c|c|c|c|c|}
\hline \multirow[b]{2}{*}{ SPECIES } & \multicolumn{3}{|c|}{ Northern Zone } & \multicolumn{4}{|c|}{ Central Zone } & \multicolumn{4}{|c|}{ SOUTHERN ZONE } \\
\hline & $\begin{array}{l}1909 \\
(351)\end{array}$ & $\begin{array}{r}1957 \\
(317)\end{array}$ & $\begin{array}{c}1958 \\
(299)\end{array}$ & $\begin{array}{l}1907 \\
(668)\end{array}$ & $\begin{array}{l}1909 \\
(488)\end{array}$ & $\begin{array}{l}1957 \\
(328)\end{array}$ & $\begin{array}{r}1958 \\
(290)\end{array}$ & $\begin{array}{r}1907 \\
(550)\end{array}$ & $\begin{array}{l}1909 \\
(433)\end{array}$ & $\begin{array}{l}1957 \\
(103)\end{array}$ & $\begin{array}{l}1958 \\
(156)\end{array}$ \\
\hline Song sparrow & - & .... & + & + & .... & -... & $\ldots$ & & .... & N & ....- \\
\hline $\begin{array}{l}\text { Great blue heroul } \\
\text { Black-crowned } \\
\text { night heron }\end{array}$ & + & $\cdots$. & & - & -..- & - & -.-- & + & $-\cdots$ & $\ldots$ & -..- \\
\hline $\begin{array}{l}\text { Red-tailed hawk } \\
\text { Red-shouldered } \\
\text { hawk }\end{array}$ & 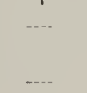 & $\cdots$ & $\cdots$ & --- & $\ldots$ & $\ldots$ & + & + & $\ldots$ & $\cdots$ & -.. \\
\hline $\begin{array}{l}\text { Yellow-billed } \\
\text { cuckoo }\end{array}$ & .... & $\cdots$ & $\cdots$ & $\ldots$ & - & + & .... & $\ldots$ & - & --o- & ...- \\
\hline $\begin{array}{l}\text { Common night- } \\
\text { hawk }\end{array}$ & $\ldots$ & $-\ldots-$ & 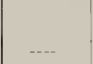 & + & & -..- & & $\ldots$ & $\cdots$ & --- & .... \\
\hline $\begin{array}{l}\text { Belted kingfisher } \\
\text { Downy wood- } \\
\text { pecker }\end{array}$ & --- & $\cdots$ & & + & -. & $\cdots$ & .... & $\begin{array}{l}\cdots \\
+\end{array}$ & $-\cdots-$ & $\cdots$ &.-- \\
\hline Tree swallow & .. & .... & + & $\ldots$ & $\ldots$ & .... & $\ldots$ & + & -... & $\cdots$ & -... \\
\hline $\begin{array}{l}\text { Bewick's wren } \\
\text { Carolina wren }\end{array}$ & $\cdots$ & $\cdots$ & -.. & - & $\cdots$. & $\ldots$ & $\cdots \cdot$ & + & + & -..- & -... \\
\hline $\begin{array}{l}\text { Baltimore oriole } \\
\text { Rose-breasted } \\
\text { grosbeak }\end{array}$ & + & $\cdots$ & $\cdots$ & & $\cdots$ & $\cdots$. & $\cdots$ & $\cdots$ & + & $\cdots-$ & $\ldots$ \\
\hline $\begin{array}{l}\text { Grasshopper } \\
\text { sparrow }\end{array}$ & & & .. & + & - & - & ---. & -..- & & .... & \\
\hline Unidentified bird & 3 & 1 & 2 & + & 1 & 2 & $\ldots$. & 1 & 1 & 1 & 2 \\
\hline $\begin{array}{l}\text { Total birds per } \\
100 \text { acres }\end{array}$ & 63 & 86 & 88 & 35 & +7 & 73 & 32 & 45 & It & 47 & 72 \\
\hline Number of species & 28 & 24 & 28 & 35 & 25 & 19 & 19 & 37 & 36 & 17 & 19 \\
\hline
\end{tabular}

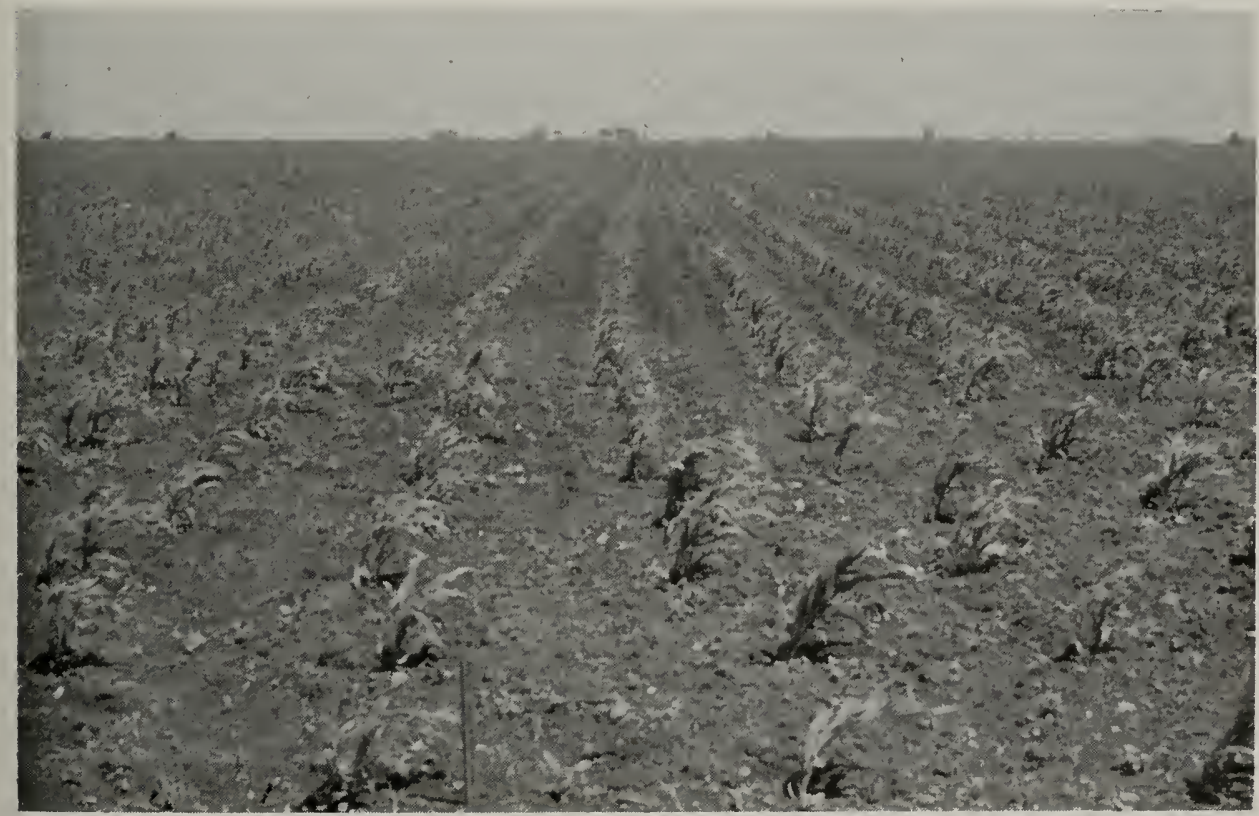

Fig. 11.-Cornfield habitat at the stage of growth encountered at the time of the June censuses. Photograph taken in Champaign County, June, 1958, by Jean W. Graber. 
and 1909 in all zones censused than in 1957 and 1958, fig. 19. The pattern is one that can be observed over and over for the open-field habitats; that is, in these habitats the earlier avifauna of common species was more varied than the recent. Related to this change is the fact that only three species (horned lark, redwinged blackbird, and barn swallow) comprised more of the cornfield population in 1957-1958 than in 1907-1909, while at least nine species were less prominent in the recent than the earlier cornfield avifauna, fig. 12.
In northern and central Illinois, by 1957 the horned lark had become the predominant cornfield species, a change reflected in the density figures, table 5 . The change in the southern zone was less pronounced.

The nesting avifauna for cornfields probably is composed principally of three species: the horned lark, vesper sparrow, and killdeer.

Because so much of the summer avifauna of cornfields does not breed in this habitat, the list of species in table 5 must reflect marginal or edge habitat to some

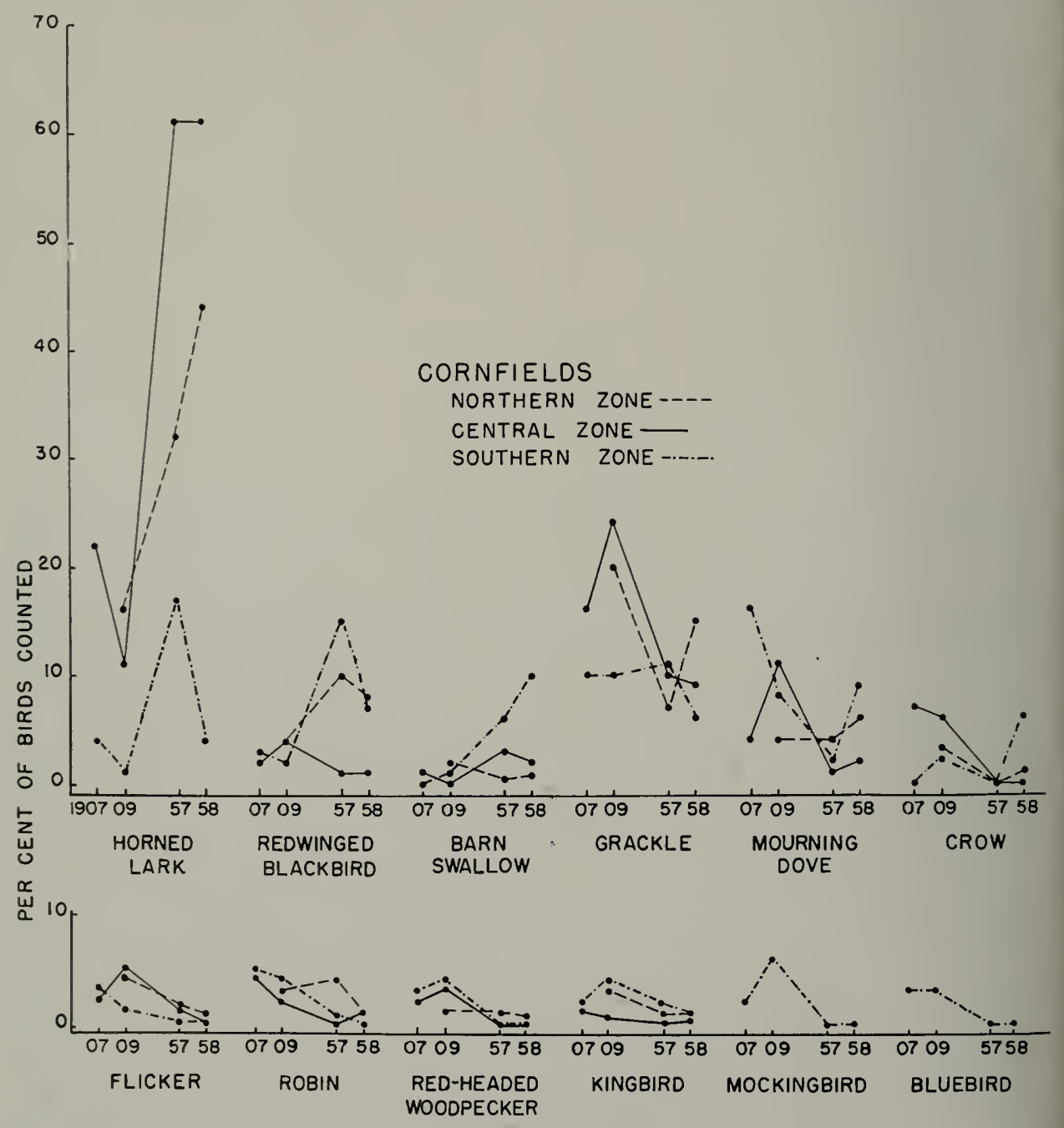

Fig. 12.- Relative abundance of common species of birds censused in cornfields of the northern, central, and southern zones of Illinois in the summers of 1907, 1909, 1957, and 1958 . Only those species are included that showed changes in relative abundance (per cent of all birds counted in cornfields) between 1909 and 1957. 
extent. In all of the census years, regional differences were apparent. The cornfield avifauna of the central zone in summer was poorer both in number of species and in density of population than that of either the northern or the southern zone.

\section{Soybean Fields (Summer)}

Soybean acreage increased in lllinois from a few thousand acres before 1920 to more than $4,000,000$ in $195+$ (Ross \& Case $1956: 71)$; 777 acres of soybean fields were censused in 1957-1958.

Soybeans were one of the crops characterized by considerable areas of bare ground at the start of the nesting season. In early June, at the start of censusing, the plants were less than 6 inches in height; by the end of the summer census season they reached 12 inches or more. During this period, the areas of bare earth were gradually closed in by the plants, and the habitat probably became less desirable for the open-field bird species that predominate in bare-ground habitats.

Soybean fields were about the poorest of bird habitats, both in number of species and number of individual birds, figs. 22$2+$.

The average number of birds per acre of soybeans for the various years and zones in summer ranged from 0.1 to 0.9 . Populations tended to be lowest in the southern zone, tables 6 and 7. In central Illinois, the zone for which we had the largest samples, mean densities were 0.9 bird per acre in 1957 and 0.5 in 1958, table 6. Maximum variation of bird populations in any one zone in consecutive census years was from 0.1 to 0.5 bird per acre, in southern Illinois.

At least 28 species of birds were identified in soybean fields in the summers of 1957 and 1958, table 7. Though no species was recorded in this habitat in both years in all regions, the horned lark, grackle, redwinged blackbird, mourning dove, and goldfinch were reported with high frequency. Probably only the horned lark and the vesper sparrow nested regularly in this habitat; the horned lark was the predominant species.

\section{Plowed Fields (Summer)}

In early summer, relatively little Illinois land can be classed as plowed fields.
Only 335 acres of this habitat were censused in summers of the two study periods. Despite the total lack of cover, plowed fields had avifaunal associations about comparable to those of cornfields and sorbean fields.

Bird population densities in plowed fields in summer varied from 0.6 to $1 . t$ birds per acre (57 birds per 100 acres in 1907 to $1+0$ birds per 100 acres in 1957 , table 8$)$. In the southern zone, the only one in which large areas of plowed fields were censused, these fields held populations of about 0.6 bird per acre in 19571958, indicating relatively poor habitat.

Twenty-nine species of birds were identified in plowed fields in summer, table 8 ; this fauna was slightly richer in species than that found in urban residential areas. Probably a very low percentage of the species found in plowed fields actually nested in this habitat. Probable nesting species were the horned lark and the killdeer.

Only in the southern zone was the census area of plowed fields large enough to warrant avifaunal comparisons between the two census periods. In this zone, 10 species of birds comprised the common summer avifauna of plowed fields censused in 1907 and only 7 species in 1958, fig. 19. In plowed fields, as in soybean fields and cornfields, the horned lark was the predominant summer species, figs. 12 and 13 and table 7.

\section{Oat Fields (Summer)}

The acreage of oats in Illinois decreased from about $4,300,000$ acres in 1907 to $2,800,000$ acres in 1957. The reduction was accompanied by an increase in soybean production. In all census years, oat production was higher in the northern two-thirds of the state than in the southern third.

In summers of the two study periods, 1,319 acres of oats fields were censused, table 3 , only about 300 acres in 19571958. Only 10 acres were censused in the southern zone in 1957-1958. At the time of the summer censuses, the oat plants had attained nearly full growth (12-18 inches) and were headed out. The fields were green in the early part of the census and ripened before the end of July. Most fields had scattered weeds that produced 
Table 6.- Statistical data on summer bird populations in Illinois soybean fields as determined by strip censuses in the three zones. Data are (1) from all soybean fields censused and (2) from sample areas (each 10 acres or more) in these fields.

\begin{tabular}{|c|c|c|c|c|c|c|c|c|}
\hline \multirow{3}{*}{$\begin{array}{l}\text { ZONE } \\
\text { AND } \\
\text { YEAR }\end{array}$} & \multicolumn{2}{|c|}{$\begin{array}{l}\text { ALL SOYBEAN } \\
\text { FIELDS CENSUSED }\end{array}$} & \multicolumn{6}{|c|}{ SAMPLE AREAS } \\
\hline & \multirow[b]{2}{*}{ Acres } & \multirow[b]{2}{*}{$\begin{array}{c}\text { Birds } \\
\text { Per Acre }\end{array}$} & \multirow[b]{2}{*}{ Number } & \multicolumn{5}{|c|}{ Birds Per Acre } \\
\hline & & & & Range & Mean & $\begin{array}{l}\text { Standard } \\
\text { Deviation }\end{array}$ & $\begin{array}{c}\text { Standard } \\
\text { Error }\end{array}$ & $\begin{array}{l}\text { Mean } \pm \\
\text { 2S.E. }\end{array}$ \\
\hline \multicolumn{9}{|l|}{ Northern } \\
\hline 1957 & 24 & 0.4 & & & & ---- & $\ldots$ & $\cdots$ \\
\hline 1958 & 143 & 0.7 & 6 & $0.1-2.1$ & 0.8 & $-\cdots$ & -..- & $\cdots$ \\
\hline \multicolumn{9}{|l|}{ Central } \\
\hline $\begin{array}{l}1957 \\
1958\end{array}$ & 250 & 0.9 & 9 & $0.4-1.5$ & 0.9 & 0.4 & 0.1 & $0.7-1.1$ \\
\hline $\begin{array}{l}1958 \\
\text { Southern }\end{array}$ & 239 & 0.5 & 9 & $0.2-0.9$ & 0.6 & 0.2 & 0.1 & $0.4-0.8$ \\
\hline \multicolumn{9}{|l|}{ Southern } \\
\hline 1957 & 46 & 0.1 & 3 & $0.0-0.2$ & 0.1 & ...- & $\ldots$ & $\ldots$ \\
\hline 1958 & 75 & 0.5 & 4 & $0.2-0.5$ & 0.3 & . & $\ldots$ & $\ldots$ \\
\hline
\end{tabular}

Table 7.-Summer avifauna in Illinois soybean fields (birds per 100 acres) as determined by strip censuses in the three zones. Figures in parentheses indicate numbers of acres censused; + indica:es less than 1 bird per 100 acres; * indicates breeding species in this habitat.

\begin{tabular}{|c|c|c|c|c|c|c|}
\hline \multirow{2}{*}{ Species } & \multicolumn{2}{|c|}{ Northern Zone } & \multicolumn{2}{|c|}{ Central Zone } & \multicolumn{2}{|c|}{ SOUTHERn ZONE } \\
\hline & $\begin{array}{l}1957 \\
(24)\end{array}$ & $\begin{array}{c}1958 \\
(143)\end{array}$ & $\begin{array}{c}1957 \\
(250)\end{array}$ & $\begin{array}{l}1958 \\
(239)\end{array}$ & $\begin{array}{l}1957 \\
(\div 6)\end{array}$ & $\begin{array}{l}1958 \\
(7 j)\end{array}$ \\
\hline *Horned lark & & 33 & 57 & 36 & ..... & 11 \\
\hline Common grackle & 21 & 10 & 4 & 1 & ..-. & 4 \\
\hline Redwinged blackbird & 12 & 5 & 2 & 2 & $\ldots$ & 7 \\
\hline Mourning dove & $\ldots$ & 4 & 6 & 2 & 2 & 9 \\
\hline House sparrow & $\ldots$ & 2 & 8 & 3 & $\ldots$ & 3 \\
\hline Meadowlark (species?) & $\ldots$ & 3 & 3 & 2 & $\ldots$ & 3 \\
\hline American goldfinch & 4 & 3 & 1 & 1 & 2 & \\
\hline Killdeer & --- & 2 & $\cdots$ & - & --- & 7 \\
\hline $\begin{array}{l}\text { Barn swallow } \\
\text { Ring-necked pheasant }\end{array}$ & - & 1 & + & 2 & $\cdots$ & 5 \\
\hline Ring-necked pheasant & 4 & --- & --- & --- & $-\cdots$ & --- \\
\hline $\begin{array}{l}\text { Spotted sandpiper } \\
\text { Indigo bunting }\end{array}$ & 4 & $-\cdots-$ & + & + & 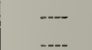 & $\overline{3}$ \\
\hline Robin - - - - & $\ldots$ & & 1 & -.- & 2 & $\ldots$ \\
\hline *Vesper sparrow & $\cdots$ & 3 & - & --.- & $\ldots$ & $\ldots$ \\
\hline Chimney swift & -... & $\ldots$ & - & 2 & -.- & $\ldots$ \\
\hline Starling & -.-- & 1 & - & 1 & $\ldots$ & -- \\
\hline $\begin{array}{l}\text { Mockingbird } \\
\text { Dickcissel }\end{array}$ & -..- & $\cdots \cdot$ & + & $\ldots$ & $\cdots$ & 1 \\
\hline $\begin{array}{l}\text { Dickcissel } \\
\text { Purple martin }\end{array}$ & -- & 1 & 1 & + & $\cdots-$ & --- \\
\hline Savannah sparrow & $\ldots$ & 1 & $\ldots$ & -.- & $\ldots$ & $\ldots$ \\
\hline Lark sparrow & .... & ... & 1 & $\ldots$ & $\ldots$ & $\ldots$ \\
\hline Field sparrow & ...- & 1 & & .--- & --- & -.-- \\
\hline Turkey vulture & $\ldots$ & --- & + & --- & --- & -..- \\
\hline Bobwhite & $\ldots$ & -..- & + & -..- & --. & -..- \\
\hline Upland plover & ....- & --- & + & -..- & -.-- & -..- \\
\hline Loggerhead shrike & $\ldots$ & -..- & + & $\ldots$ & -.-. & -.- \\
\hline *Brown-headed cowbird & --- & -.- & -- & + & --- & -- \\
\hline Grasshopper sparrow & $\cdots$ & 1 & 1 & + & --- & - \\
\hline Unidentified bird & 45 & 71 & $\begin{array}{r}1 \\
88\end{array}$ & $55^{\prime}$ & 6 & 53 \\
\hline Total birds per 100 acres & 43 & 14 & 88 & 55 & 0 & 53 \\
\hline Number of species & 5 & & 17 & 14 & 3 & 10 \\
\hline
\end{tabular}


Table 8.-Summer avifauna in 11 linois plowed fields (birds per 100 acres) as determined by strip censuses in two zones. Figures in parentheses indicate numbers of acres censused.

\begin{tabular}{|c|c|c|c|c|c|}
\hline \multirow[b]{2}{*}{ SPECIES } & \multirow{2}{*}{$\begin{array}{l}\text { Central Zone } \\
\begin{array}{r}1957 \\
(25)\end{array}\end{array}$} & \multicolumn{4}{|c|}{ SOUTHERN ZONE } \\
\hline & & $\begin{array}{l}1907 \\
(68)\end{array}$ & $\begin{array}{l}1909 \\
(66)\end{array}$ & $\begin{array}{l}1957 \\
(83)\end{array}$ & $\begin{array}{l}1958 \\
(56)\end{array}$ \\
\hline Horned lark & 92 & 6 & 15 & 13 & $1+$ \\
\hline Brown-headed cowbird & 8 & 1 & 35 & + & 9 \\
\hline $\begin{array}{l}\text { Mouruing dove } \\
\text { Killdeer }\end{array}$ & 12 & $\begin{array}{l}9 \\
+\end{array}$ & 21 & $\begin{array}{r}7 \\
17\end{array}$ & 7 \\
\hline Lark sparrow & 16 & + & 4 & 17 & $\cdots$ \\
\hline $\begin{array}{l}\text { Robin } \\
\text { Common grackle }\end{array}$ & & $\begin{array}{l}7 \\
1\end{array}$ & 8 & 2 & 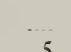 \\
\hline Eastern kingbird & 8 & $\begin{array}{l}1 \\
t\end{array}$ & $\begin{array}{l}8 \\
1\end{array}$ & $\begin{array}{l}2 \\
2\end{array}$ & 5 \\
\hline House sparrow & .. & 3 & 9 & & 3 \\
\hline Redwinged blackbird & $\therefore$ & 1 & & + & 7 \\
\hline Eastern meadowlark & - & 1 & 1 & 6 & 3 \\
\hline Field sparrow $\ldots . . . . .$. & & $\ldots$ & 8 & --- & $\cdots$. \\
\hline Brown thrasher & $\ldots$ & 1 & 6 & & $\cdots$ \\
\hline $\begin{array}{l}\text { Indigo bunting } \\
\text { Eastern bluebird }\end{array}$ & $\cdots$ & & 6 & 1 & 2 \\
\hline $\begin{array}{l}\text { Red-tailed hawk } \\
\text { Red-headed woodpecker }\end{array}$ & + & + & -. & & $\cdots$ \\
\hline Common crow & & & & 2 & 2 \\
\hline Bewick's wren & & 4 & & & $\ldots$ \\
\hline Mockingbird & & & 4 & $\cdots$ & -... \\
\hline Loggerhead shrike & & 1 & 3 & & -. \\
\hline Chimney swift & & 3 & - & & \\
\hline $\begin{array}{l}\text { Dickcissel } \\
\text { Yellow-shafted flicker }\end{array}$ & & $\cdots$ & $\cdots$ & 1 & $\begin{array}{l}2 \\
2\end{array}$ \\
\hline $\begin{array}{l}\text { Yellow-shafted flicker } \\
\text { Red-shouldered hawk }\end{array}$ & $\cdots$ & $\ldots$ & 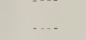 & 1 & $\ldots$ \\
\hline Bobwhite & $\cdots$ & & 1 & $\cdots$ & $\ldots$. \\
\hline Upland plover & $=$ & 1 & - & $\cdots$ & $\ldots .$. \\
\hline $\begin{array}{l}\text { Black-billed cuckoo } \\
\text { Downy woodpecker }\end{array}$ & & $\begin{array}{l}1 \\
1\end{array}$ & & $\ldots$ & $\cdots$ \\
\hline Total birds per 100 acres & 140 & 57 & 130 & 62 & 56 \\
\hline Number of species & 6 & 19 & 15 & 13 & 11 \\
\hline
\end{tabular}

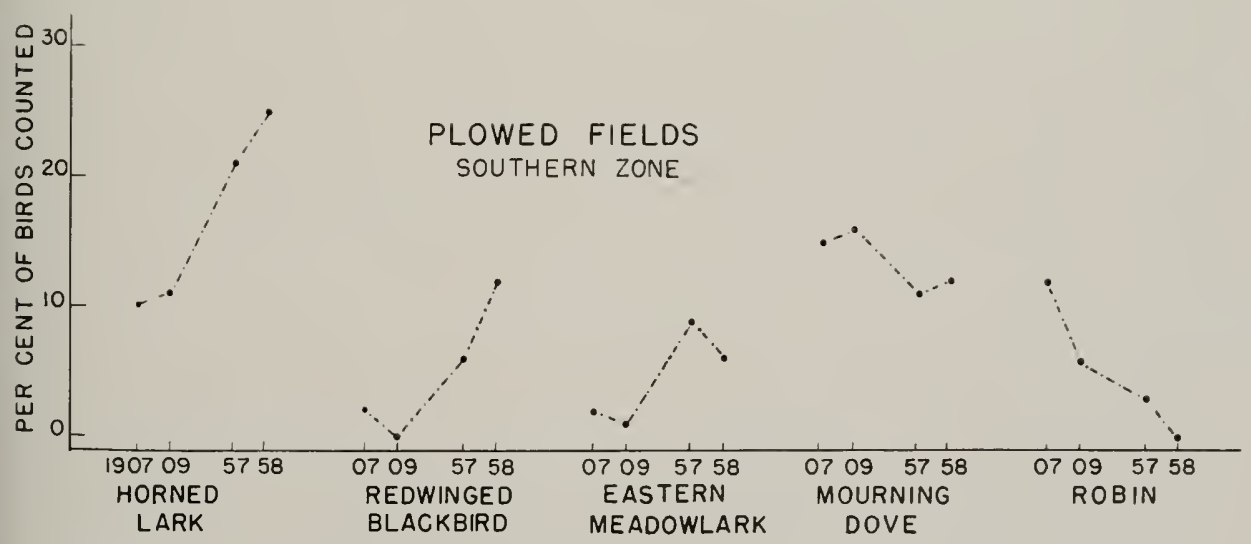

Fig. 13.-Relative abundance of common species of birds censused in plowed fields of the southern zone of IIlinois in the summers of 1907, 1909, 1957, and 1958. Only those species are included that showed changes in relative abundance (per cent of all birds counted in plowed fields) between 1909 and 1957. 
an aspect more like that of hayfields than other grain crops, and the avifauna showed some resemblance to the nesting avifauna in havfields.
For all census years and zones, mean densities of summer bird populations in oats varied from 0.5 to 2.7 birds per acre; the greatest variation in consecutive years

Table 9.-Statistical data on summer bird populations in lllinois oat fields as determined by strip censuses in the three zones. Data are (1) from all oat fields censused and (2) from sample areas (each 10 acres or more) in these fields. The data from sample areas are for breeding species only.

\begin{tabular}{|c|c|c|c|c|c|c|}
\hline \multirow{3}{*}{$\begin{array}{c}\text { ZONE } \\
\text { AND } \\
\text { IEAR }\end{array}$} & \multicolumn{3}{|c|}{ All. OAt Fields Censused } & \multicolumn{3}{|c|}{ SAMPLE AREAS } \\
\hline & \multirow[b]{2}{*}{ Acres } & \multicolumn{2}{|c|}{ Birds Per Acre } & \multirow[b]{2}{*}{ Number } & \multicolumn{2}{|c|}{ Birds Per Acre (Breeding Species) } \\
\hline & & $\begin{array}{c}\text { All } \\
\text { Species }\end{array}$ & $\begin{array}{l}\text { Breeding } \\
\text { Species } \\
\text { Only }\end{array}$ & & $\begin{array}{c}\text { Observed } \\
\text { Range }\end{array}$ & Mean \\
\hline \multicolumn{7}{|l|}{ Northern } \\
\hline 1909 & $2+1$ & 0.5 & 0.1 & 7 & $0.0-0.3$ & 0.1 \\
\hline 1957 & 95 & 2.7 & 2.0 & 5 & $0.9-3.8$ & 2.0 \\
\hline 1958 & 71 & 1.3 & 1.2 & 3 & $0.2-1.8$ & .... \\
\hline \multicolumn{7}{|l|}{ Central } \\
\hline 1907 & 408 & 0.6 & 0.2 & 10 & $0.0-0.8$ & 0.2 \\
\hline 1909 & 188 & 0.6 & 0.3 & 6 & $0.1-0.4$ & 0.3 \\
\hline 1957. & 67 & 1.1 & 0.7 & + & $0.1-0.4$ & -... \\
\hline 1958 & 56 & 1.0 & 0.3 & 2 & $0.2-0.6$ & $\ldots$ \\
\hline \multicolumn{7}{|l|}{ Southern } \\
\hline 1907 & $1+5$ & 0.5 & 0.2 & 8 & $0.0-0.7$ & 0.2 \\
\hline 1909 & 38 & 1.0 & 0.6 & 2 & $\ldots$ & -... \\
\hline
\end{tabular}

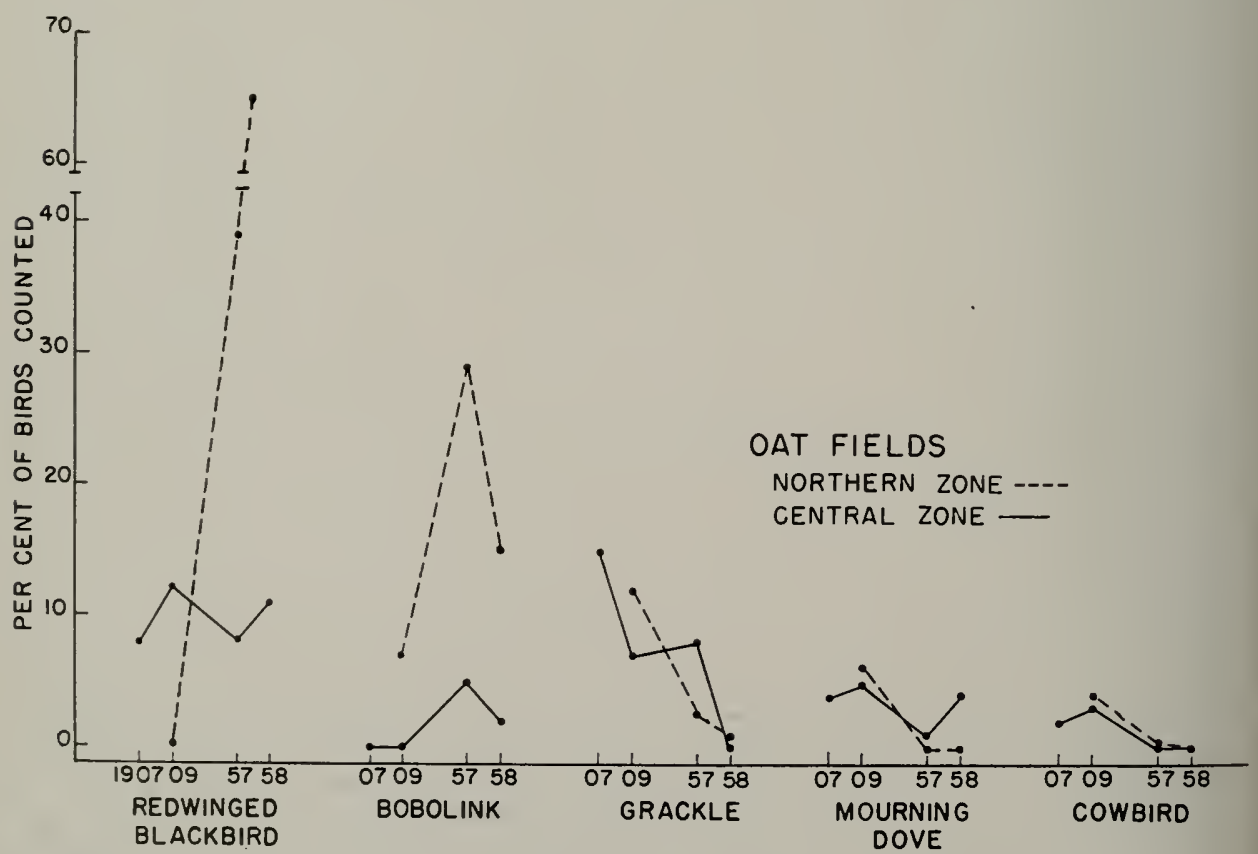

Fig. 14.-Relative abundance of common species of birds censused in oat fields of the northern and central zones of Illinois in the summers of 1907, 1909, 1957, and 1958. Only those species are included that showed changes in relative abundance (per cent of all birds counted in oat fields) between 1909 and 1957. 
was from 2.7 birds per acre in 1957 to 1.3 the density of bird populations in oat in 1958, in the northern zone, table 9. fields ranged from 0.5 to 1.0 bird per acre Densities were higher in the northern than in other zones and in the later than in the early series of censuses. In 1907-1909, and averaged 0.7 , about comparable to density of the populations in cornfields. In 1957 and 1958, the population in oat

Table 10.- Summer avifauna in Illinois oat fields (birds per 100 acres) as determined by strip censuses in the three zones. Figures in parentheses indicate numbers of acres censused; + indicates less than 1 bird per 100 acres; * indicates breeding species in this habitat.

\begin{tabular}{|c|c|c|c|c|c|c|c|c|c|}
\hline \multirow[b]{2}{*}{ SPECIES } & \multicolumn{3}{|c|}{ Northern ZoNe } & \multicolumn{4}{|c|}{ Central Zone } & \multicolumn{2}{|c|}{ SOUTHERN ZONE } \\
\hline & $\begin{array}{c}1909 \\
(2+1)\end{array}$ & $\begin{array}{l}1957 \\
(95)\end{array}$ & $\begin{array}{l}1958 \\
(71)\end{array}$ & $\begin{array}{c}1907 \\
(408)\end{array}$ & $\begin{array}{l}1909 \\
(188)\end{array}$ & $\begin{array}{l}1957 \\
(67)\end{array}$ & $\begin{array}{l}1958 \\
(56)\end{array}$ & $\begin{array}{c}1907 \\
(1+5)\end{array}$ & $\begin{array}{l}1909 \\
(38)\end{array}$ \\
\hline *Redwinged blackbird & & 107 & 87 & 5 & 8 & 9 & 11 & 1 & 18 \\
\hline House sparrow & 17 & 23 & 3 & 8 & 8 & 13 & 59 & 7 & 8 \\
\hline *Bobolink & 4 & 78 & 20 & & & 6 & 2 & & \\
\hline Meadowlark (species?) & 1 & 11 & 3 & 5 & 6 & 6 & 9 & 13 & 26 \\
\hline Common grackle & 7 & 9 & 1 & 9 & 5 & 9 & $\ldots$. & 1 & 21 \\
\hline *Dickcissel & + & 1 & & 5 & 10 & 25 & 9 & 1 & 5 \\
\hline *Horned lark & 1 & 2 & $\ldots$ & 7 & + & 21 & & 1 & 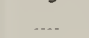 \\
\hline Mourning dove & 3 & $\ldots$ & $\ldots$ & 2 & 3 & 1 & 4 & + & 5 \\
\hline Bobwhite & $\ldots$ & $\ldots$ & $\ldots$. & + & 2 & 1 & $\ldots$ & 5 & 8 \\
\hline *Ring-necked pheasant & $\ldots$ & 2 & 13 & $\ldots$ & $\ldots$ & $\ldots$ & $\ldots$ & & $\ldots$. \\
\hline American goldfinch & 2 & 9 & 3 & 1 & $\ldots$ & $\ldots$ & $\ldots$ & $\cdots$ & $\ldots$ \\
\hline Barn swallow & 1 & 1 & 1 & + & + & + & + & 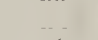 & $\ldots$ \\
\hline Yellow-shafted flicker & 1 & 1 & 1 & 1 & 2 & 1 & $\ldots$ & 1 & -.-- \\
\hline Common crow & 5 & & $\ldots$ & + & + & $\ldots$ & $\ldots$. & 2 & $\ldots$ \\
\hline Robin & + & 1 & $\ldots$ & $\ldots$ & 1 & 1 & $\ldots$ & 1 & 3 \\
\hline Eastern kingbird & + & $\ldots-$ & $\ldots$. & 1 & 2 & 3 & $\ldots$. & $\ldots$ & $-\ldots$ \\
\hline Brown thrasher & + & $\cdots$ & $\ldots$ & + & 3 & $\ldots$ & $\cdots$ & $\ldots$ & 3 \\
\hline Starling & $\cdots$ & 6 & $\ldots$ & $\cdots$ & -- & $\ldots$. & $\ldots$ & $\ldots$ & $\ldots$ \\
\hline *Brown-headed cowbird. & 2 & 1 & --- & 1 & 2 & $\ldots$ & $\ldots$ & $\ldots$ & $\cdots$ \\
\hline Killdeer & $\ldots$ & $\ldots$ & $\cdots$ & 1 &.- & + & $\cdots$ & $\cdots$ & -.-. \\
\hline *Grasshopper sparrow & $\ldots$. & .... & 1 & + & $\ldots$ & $\ldots$ & $\ldots$ & $\ldots$ & $\ldots$ \\
\hline Upland plover & $\ldots$ & .... & $\ldots$ & $\ldots$ & + & 3 & $\cdots$. & 1 & $\cdots$ \\
\hline Yellowthroat & $\ldots$ & $\ldots$ & $\cdots$ & $\ldots-$ & + & $\cdots$ & .... & 1 & 3 \\
\hline Sparrow hawk $\ldots . . . .$. & $\ldots-$. & $\ldots$ & $\ldots$ & + & $\ldots$ & $\ldots$. & $\cdots-$ & $\cdots \cdot$ & 3 \\
\hline Purple martin & $-\cdots$ & 3 & + & $-\cdots$ & $\ldots$ & $\ldots$ & $-\cdots$ & $\ldots$ & $-\cdots$ \\
\hline Indigo bunting & $\ldots$ & 1 & $\ldots$ & + & 1 & $\ldots .$. & $\ldots$. & 1 & $\ldots$ \\
\hline Field sparrow. & $\ldots$ & $\ldots$ & .... & 1 & 2 & $\ldots$. & $\ldots$ & 1 & $\ldots$ \\
\hline *Lark sparrow & $\ldots$ & $\ldots$. & $\ldots$ & + & + & $\ldots$. & $\ldots$ & 2 & $-\ldots$ \\
\hline Catbird & + & & $\ldots$ & .... & $\ldots$ & $\ldots$ & ...- & 2 & $\ldots$ \\
\hline Chimney swift & 1 & 1 & $\ldots$ & 1 & -.- & $\ldots$ & $\ldots$ & $\ldots$ & $\ldots$. \\
\hline Red-headed woodpecker & 1 & & $\ldots$. & $\cdots$ & 1 & $\ldots$ & $\ldots$ & & .... \\
\hline Loggerhead shrike & $\ldots$ & .... & $\cdots$ & 1 & $-\ldots$ & $\cdots$ & & 1 & .... \\
\hline Cardinal & $\ldots$. & & $\ldots$ & & $\ldots$ & $\ldots$ & 2 & $\ldots$ & $\ldots$. \\
\hline *Vesper sparrow..... & + & 1 & $\ldots$ & + & + & -... & $\cdots$ & & $\ldots$ \\
\hline Song sparrow & + & $\ldots$ & $\ldots$ & + & 1 & $\cdots$ & $\ldots$. & $\cdots$ & $\ldots$ \\
\hline Cliff swallow & $\ldots$. & .... & $\ldots$ & $\ldots$ & $\ldots$ & $\ldots$ & $\ldots$ & 1 &.-- \\
\hline Blue jay & $\cdots$ & $\ldots$ & $\cdots$ & 1 & 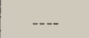 & --- & $\cdots$ & --- & $\cdots$ \\
\hline Eastern bluebird & 1 & ... & $-\cdots$ & $\ldots$ & $\ldots$ & $\cdots$ & $\ldots$ & $\ldots$ & $\cdots$ \\
\hline Savannah sparrow & $\ldots$. & -... & $\ldots$ & 1 & $\ldots$ &..- & .... & & -... \\
\hline Bachman's sparrow & $\ldots$ & -..- & ...- & $\ldots$. & $\cdots$ & ...- & -.- & 1 & --- \\
\hline Black-crowned night heron & + & -..- & $\ldots$ & $\ldots$. & $\ldots$. & $\ldots$. & $\ldots$. & $\cdots$. & $\ldots$ \\
\hline Eastern phoebe & $\ldots$ & -.. & .... & + & -.- & .... & $\ldots$. & & $\ldots$. \\
\hline Baltimore oriole & + & .... & $\ldots$ & $\ldots$ & $\cdots$ & -... & $\cdots$ & $\ldots$ & $\cdots$ \\
\hline Chipping sparrow & $\ldots$ & -... & $-\ldots$ & $\ldots$ & + & .... & $\ldots$. & & $\cdots$ \\
\hline Unidentified bird & 2 & 10 & $\ldots$ & 2 & 3 & + & .... & & $\ldots$ \\
\hline Total birds per 100 acres & 55 & 268 & $13 t$ & 61 & 65 & 111 & 100 & 48 & 103 \\
\hline Number of species & 22 & 18 & 11 & 27 & 24 & 15 & 8 & 20 & 11 \\
\hline
\end{tabular}


fields ranged from 1.0 to 2.7 birds per acre and averaged 1.5 , a density well above that for cornfields.
Population densities of breeding species showed minimum and maximum figures for 1907-1909 of 0.1 bird per acre (in the

Table 11.-Statistical data on summer bird populations in Illinois wheat fields as determined by strip censuses in two zones. Data are (1) from all wheat fields censused and (2) from sample areas (each 10 acres or more) in these fields. The data from sample areas are for breeding species only:

\begin{tabular}{|c|c|c|c|c|c|c|}
\hline \multirow{3}{*}{$\begin{array}{l}\text { ZONE } \\
\text { AND } \\
\text { YEAR }\end{array}$} & \multirow{2}{*}{\multicolumn{3}{|c|}{$\frac{\text { All. Wraeat Fields Censused }}{\text { Birds Per Acre }}$}} & \multicolumn{3}{|c|}{ SAMPLE AREAS } \\
\hline & & & & \multirow[b]{2}{*}{ Number } & \multicolumn{2}{|c|}{ Birds Per Acre (Breeding Species) } \\
\hline & Acres & $\begin{array}{c}\text { All } \\
\text { Species }\end{array}$ & $\begin{array}{l}\text { Breeding } \\
\text { Species } \\
\text { Only }\end{array}$ & & $\begin{array}{c}\text { Observed } \\
\text { Range }\end{array}$ & Mean \\
\hline $\begin{array}{c}\text { Central } \\
1909\end{array}$ & 141 & 0.8 & 0.2 & + & $0.0-0.4$ & 0.2 \\
\hline \multirow{2}{*}{$\begin{array}{c}\text { Southern } \\
1907\end{array}$} & & & & & & \\
\hline & $\begin{array}{r}227 \\
75\end{array}$ & $\begin{array}{l}0.8 \\
0.6\end{array}$ & $\begin{array}{l}0.2 \\
0.1\end{array}$ & $\begin{array}{r}10 \\
3\end{array}$ & $\begin{array}{l}0.0-0.5 \\
0.1-0.2\end{array}$ & $\begin{array}{l}0.3 \\
0.2\end{array}$ \\
\hline $\begin{array}{l}1909 \\
1957\end{array}$ & 97 & 0.6 & 0.3 & 4 & $0.0-1.4$ & 0.4 \\
\hline
\end{tabular}

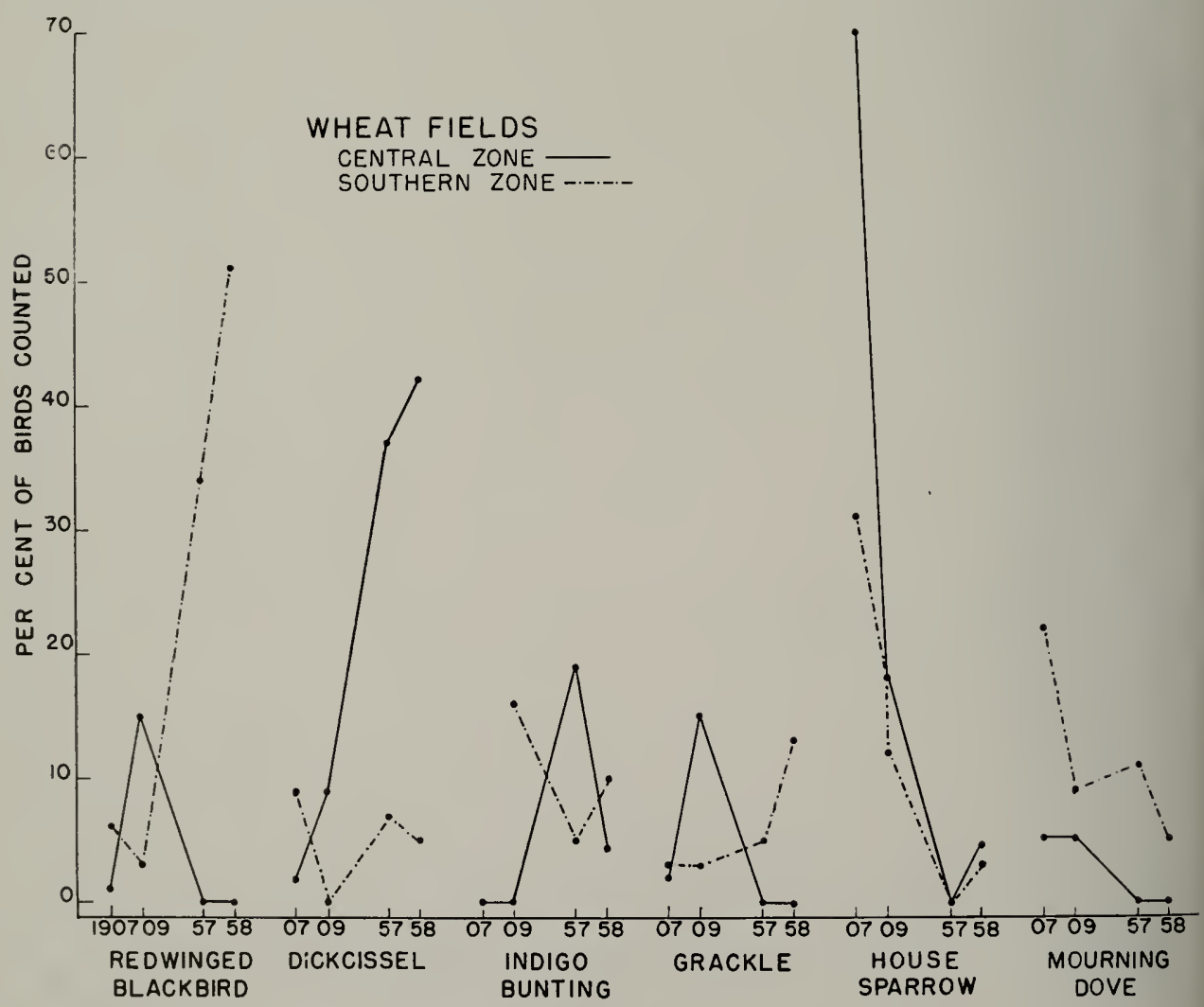

Fig. 15.-Relative abundance of common species of birds censused in wheat fields of the central and southern zones of Illinois in the summers of 1907,1909, 1957, and 1958. Only those species are included that showed changes in relative abundance (per cent of all birds counted in wheat fields) between 1909 and 1957. 
northern zone) and 0.6 per acre (in the southern zone) ; for 1957-1958, these figures were 0.3 bird per acre (in the central zone) and 2.0 birds per acre (in the northern zone), table 9.

Because census samples were small for the later years, we must be cautious in drawing conclusions, but the data indicate that summer bird population densities increased in oat fields between 1909 and 1957. The change in population densities of birds in this habitat can probably be attributed to population changes in a few species, particularly the redwinged blackbird and the bobolink, fig. 14 .
At least $4+$ species of birds were recorded in oat fields in summers of the two census periods combined, table 10 , but only 2, the house sparrow and the eastern meadowlark, were found in all zones and in all years. The number of species recorded was considerably greater in 1907-1909 than in 1957-1958, probably because of the greater acreage covered in the early census period.

\section{Wheat Fields (Summer)}

The acreage of Illinois land planted to wheat has varied greatly since 1909. From about $2,000,000$ acres in the period 1890

Table 12.-Summer avifauna in Illinois wheat fields (birds per 100 acres) as determined by strip censuses in two zones. Figures in parentheses indicate numbers of acres censused; + indicates less than 1 bird per 100 acres; ${ }^{*}$ indicates breeding species in this habitat.

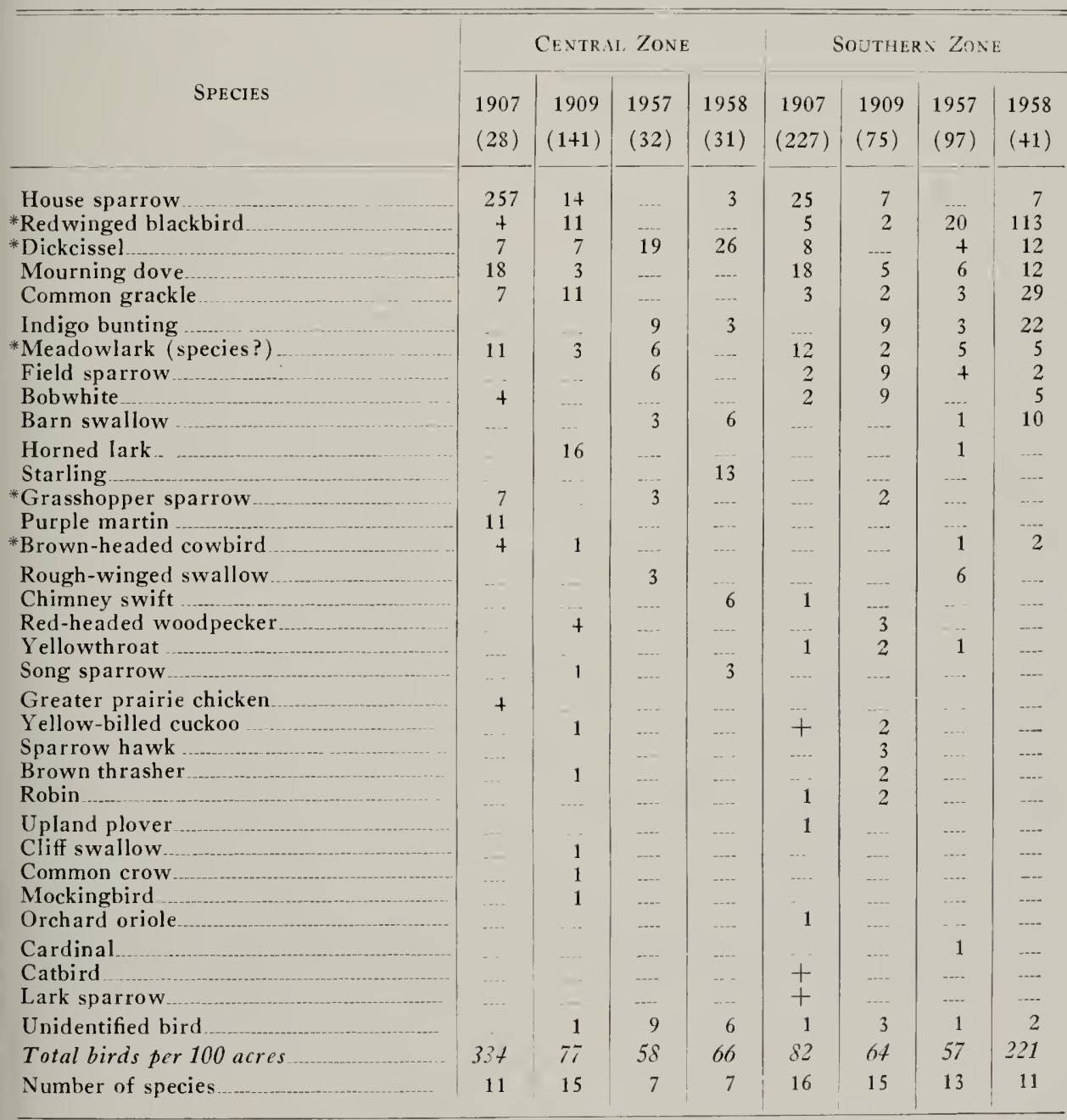


1905, wheat land increased to over $t, 000$,000 acres in 1919 and then decreased to an average of $1,500,000$ per year in the period 19+0-1950 (Ross \& Case 1956: 70). This crop in Illinois is grown mainly in the southern and central zones, and virtually all of the 773 acres of wheat fields censused for birds represented these zones.

At the time censusing started each year, the wheat plants were $1.5-2$ feet tall, green, and headed out. The plants ripened during June and July and were cut in July and August. Ripe wheat would appear to be an inhospitably warm habitat for birds.

Wheat fields were found to be a relatively poor habitat for birds in summer, figs. 22-2t, supporting populations slightly higher than those in the crops of corn and beans. Basic statistical data for years in which the largest acreages were censused are presented in table 11. For these years the number of birds per acre in wheat fields ranged from 0.6 to 0.8 , in southern Illinois. Breeding species usually comprised one-fourth to one-half of the total population in wheat fields and varied from 0.1 to 0.3 bird per acre. The data, though meager, suggest that the density of wheat field populations was about the same in the central and southern zones and in the two census periods.

At least 33 species of birds were identified in wheat fields in summer, table 12 . No species was reported in all years in both the central and southern zones, but the mourning dove was a common species in all years in the southern zone. In both zones, the eastern meadowlark and the dickcissel were recorded with very high frequency. These species, the redwinged hlackbird, and the grasshopper sparrow nested in wheat fields at least in the early part of the summer, though wheat is probably poor nesting habitat for any species.

In the central zone, the dickcissel used this habitat more in 1957-1958 than in 1907-1909, table 12 ; in the southern zone, the redwinged blackbird was the predominant species on wheat land at the time of the second survey, fig. 15 .

\section{Pastures (Summer)}

The censuses indicated a marked reduction in pasture acreage between 1909 and 1957, particularly in the central and

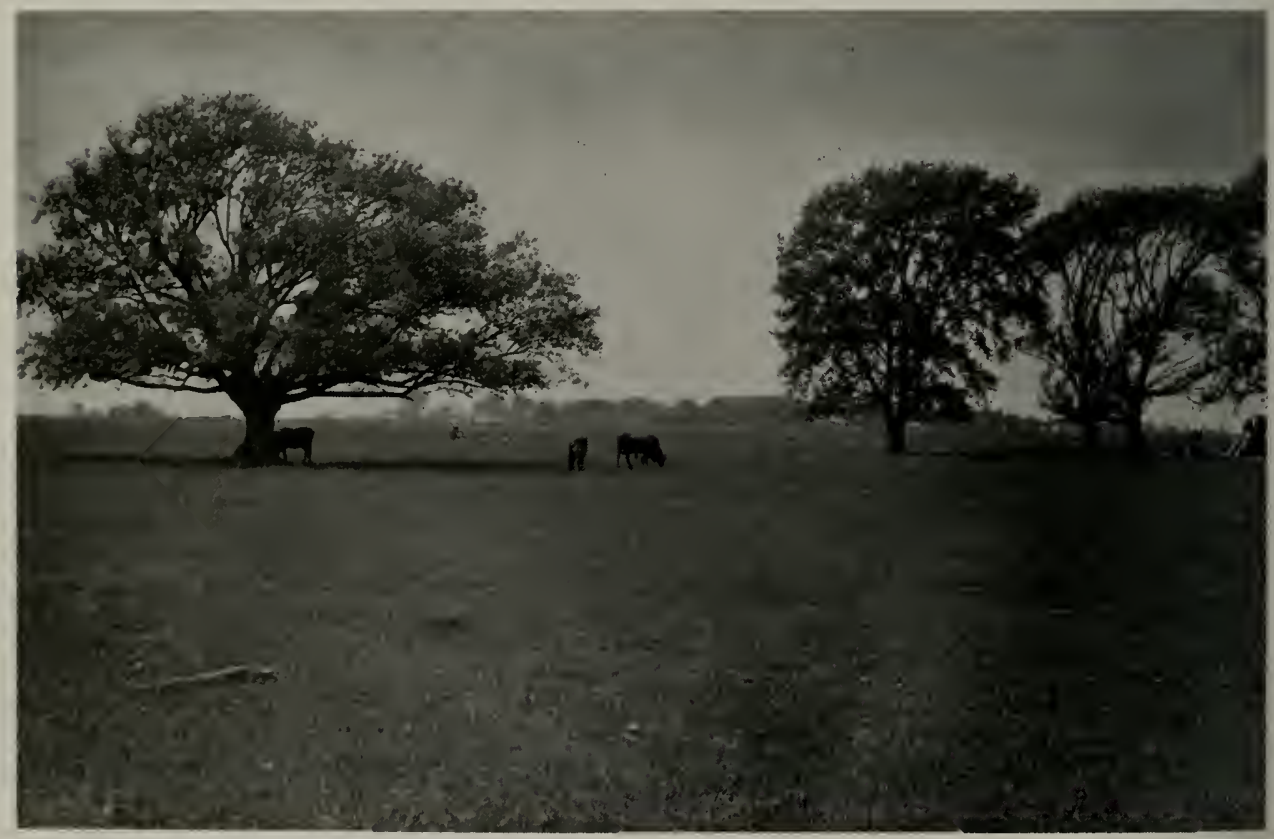

Fig. 16.-Pastureland with trees. The acreage of savanna-like habitats of this kind was greatly reduced between 1909 and 1957. The reduction contributed importantly to a loss of species variety in the avifauna of many parts of Illinois. Photograph taken near Ogden, Illinois, May 28, 1907, by Alfred O. Gross. 
southern zones. In summers of the two study periods, 2,087 acres of pasture were censused for birds, only one-fourth of this total in 1957-1958. We estimated that the area of nonwoodland pasture declined from about $6,100,000$ acres in 1907 to $2,000,000$ in 1957.

The pastures referred to in this report were virtually all stands of bluegrass (Poa pratensis), some with scattered low in the central zone. Bird population densities were highest in the central and northern zones and tended to be higher in the second census period than in the first.

A clearer picture of the pasture populations and their variations is obtained if only known breeding species are considered, tables 13 and $1+$ and fig. 17. The average number of breeding birds per acre of pasture in the various censuses ranged

Table 13.-Statistical data on summer bird populations in Illinois pastures as determined by strip censuses in the three zones. Data are (1) from all pastures censused and (2) from sample areas (each 5 acres or more) in these fields. The data from sample areas are for breeding species only.

\begin{tabular}{|c|c|c|c|c|c|c|c|c|c|}
\hline \multirow{3}{*}{$\begin{array}{c}\text { ZONE } \\
\text { AND } \\
\text { YEAR }\end{array}$} & \multicolumn{3}{|c|}{ All Pastures Censused } & \multicolumn{6}{|c|}{ SAMPLE AREAS } \\
\hline & \multirow[b]{2}{*}{ Acres } & \multicolumn{2}{|c|}{ Birds Per Acre } & \multirow[b]{2}{*}{$\begin{array}{c}\text { Num- } \\
\text { ber }\end{array}$} & \multicolumn{5}{|c|}{ Birds Per Acre (Breeding Species Only) } \\
\hline & & $\begin{array}{c}\text { All } \\
\text { Species }\end{array}$ & $\begin{array}{l}\text { Breeding } \\
\text { Species } \\
\text { Only }\end{array}$ & & Range & Mean & $\begin{array}{l}\text { Standard } \\
\text { Deviation }\end{array}$ & $\begin{array}{c}\text { Standard } \\
\text { Error }\end{array}$ & $\begin{array}{c}\text { Mean } \pm \\
\text { 2 S.E. }\end{array}$ \\
\hline \multicolumn{10}{|l|}{ Northern } \\
\hline 1909 & 193 & 2.2 & 0.8 & 7 & $0.1-1 . t$ & 0.6 & 0.5 & 0.2 & $0.2-1.0$ \\
\hline 1957 & $1+7$ & 2.1 & 1.3 & 12 & $0.7-2.3$ & 1.4 & 0.5 & 0.1 & $1.2-1.6$ \\
\hline 1958 & 132 & 2.3 & $1 . t$ & 13 & $0.1-2.9$ & 1.0 & 0.9 & 0.3 & $0.4-1.6$ \\
\hline \multicolumn{10}{|l|}{ Central } \\
\hline 1907 & 287 & 1.5 & 0.5 & 12 & $0.1-0.9$ & 0.5 & $\ldots$ & $\ldots$ & $\ldots$ \\
\hline 1909 & 155 & 2.2 & 0.9 & 7 & $0.3-1.1$ & 0.6 & $\ldots$ & 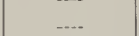 & \\
\hline $1907-1909$ & ++2 & $\ldots$ & $\ldots$ & 19 & $0.1-1.1$ & 0.6 & 0.3 & 0.1 & $0 . t-0.8$ \\
\hline 1957 & 54 & 2.9 & 1.2 & 6 & $0.7-1.7$ & 1.2 & .... & $\ldots$ & - \\
\hline 1958 & 118 & 2.2 & 0.9 & 7 & $0.2-1.3$ & 0.9 & $\ldots$ & & $\ldots$ \\
\hline \multirow{2}{*}{\multicolumn{10}{|c|}{ Southern }} \\
\hline & & & & & & & & & \\
\hline 1907 & 601 & 1.3 & 0.5 & 21 & $0.1-1.6$ & 0.5 & 0.3 & 0.2 & $0.1-0.9$ \\
\hline 1909 & 281 & 1.6 & 0.7 & 11 & $0.3-1.1$ & 0.7 & 0.2 & 0.1 & $0.5-0.9$ \\
\hline 1957. & 72 & 1.5 & 0.8 & 6 & $0.3-1.5$ & 1.1 & $\ldots$ & $\ldots$ & .... \\
\hline 1958 & 48 & 2.1 & 1.2 & 7 & $0.5-1.9$ & 1.1 & -... & & $\ldots$ \\
\hline $1957-1958$ & 120 & $\ldots$ & $\ldots$ & 13 & $0.3-1.9$ & 1.1 & 0.5 & 0.1 & $0.9-1.3$ \\
\hline
\end{tabular}

woody plants ( 6 inches -2 feet high) and a few with isolated trees, fig. 16 . The grass cover was dense, usually +10 inches high and forming a continuous mat, which was grazed by cattle or, rarely, by sheep. The characteristics of bluegrass pastures as bird habitats probably have not changed greatly in the present century.

Both quantitatively and qualitatively, pasture was shown to be a rich open-country habitat for birds, figs. 22-2t and tables 13 and 14 . Average summer densities of birds (all species) per acre in pasture for the two census periods and the three zones of the state had a range of 1.3-2.9, table 13. Maximum annual variations in consecutive census years were $1.5-2.2$ (1907-1909) and 2.9-2.2 (1957-1958), from 0.5 to 1.4 , table 13 . The highest mean population density for 1907-1909 was 0.9 bird per acre and the lowest for 1957-1958 was 0.8. The differences between mean population densities for the two study periods were consistent for all three zones of the state, fig. 17 . It seems probable that population densities of breeding birds in Illinois pastures increased, possibly even doubled, during the half century between the two study periods.

At least 76 species of birds were found in pastures, table $1+$, of which only 7 (eastern meadowlark, house sparrow, grackle, redwinged blackbird, field sparrow, cowbird, and dickcissel) were reported in all census summers of the two 
Table 14.-Summer avifauna in Illinois pastures (birds per 100 acres) as determined by strip censuses in the three zones. Figures in parentheses indicate numbers of acres censused; + indicates less than 1 bird per 100 acres; * indicates breeding species in this habitat.

\begin{tabular}{|c|c|c|c|c|c|c|c|c|c|c|c|}
\hline \multirow[b]{2}{*}{ SPECIES } & \multicolumn{3}{|c|}{ NORTHERN ZONE } & \multicolumn{4}{|c|}{ Centrai，ZONe } & \multicolumn{4}{|c|}{ SOUTHERN ZONE } \\
\hline & $\begin{array}{l}1909 \\
(193)\end{array}$ & $\begin{array}{l}1957 \\
(1+7)\end{array}$ & $\begin{array}{l}1958 \\
(132)\end{array}$ & $\begin{array}{c}1907 \\
(287)\end{array}$ & $\begin{array}{l}1909 \\
(155)\end{array}$ & $\begin{array}{l}1957 \\
(5+)\end{array}$ & $\begin{array}{l}1958 \\
(118)\end{array}$ & $\begin{array}{l}1907 \\
(601)\end{array}$ & $\begin{array}{l}1909 \\
(281)\end{array}$ & $\begin{array}{l}1957 \\
(72)\end{array}$ & $\begin{array}{l}1958 \\
(48)\end{array}$ \\
\hline $\begin{array}{c}\text { "Meadowlark } \\
\text { (species?) }\end{array}$ & 14 & 35 & 39 & 19 & 21 & 31 & $4+$ & 20 & $H$ & 58 & 56 \\
\hline House sparrow & 27 & 9 & 11 & 31 & 30 & 52 & 93 & 20 & 7 & + & 27 \\
\hline Common grackle & 28 & 8 & 16 & 15 & 21 & $+t$ & 1 & 8 & 8 & 11 & 15 \\
\hline $\begin{array}{l}\text { Redwinged black- } \\
\text { bird }\end{array}$ & 11 & 29 & 52 & 1 & 14 & 7 & 10 & 4 & 7 & + & 8 \\
\hline *Field sparrow & 6 & 3 & 2 & 5 & 3 & 20 & 19 & 10 & 5 & 11 & 33 \\
\hline $\begin{array}{l}\text { * Brown-headed } \\
\text { cowbird }\end{array}$ & 23 & 6 & + & 2 & 31 & 15 & 1 & 2 & 5 & 5 & $\begin{array}{r}8 \\
33\end{array}$ \\
\hline $\begin{array}{l}\text { Barn swallow } \\
\text { Yellow-shafted }\end{array}$ & 7 & 9 & 11 & 2 & 3 & 7 & 2 & + & $\cdots$ & 7 & 33 \\
\hline flicker & 17 & 3 & 3 & 8 & 15 & 2 & 2 & $\frac{3}{5}$ & $\begin{array}{l}+ \\
5\end{array}$ & + & $\cdots$ \\
\hline $\begin{array}{l}\text { Robin } \\
\text { *Grasshopper }\end{array}$ & 12 & 1 & 1 & 10 & 9 & 2 & 2 & 5 & 5 & + & $\cdots$ \\
\hline sparrow & 3 & 7 & 5 & 4 & 2 & 20 & + & 2 & + & 3 & $\ldots$. \\
\hline $\begin{array}{l}\text { Starling } \\
\text { * Savannah spar- }\end{array}$ & & 13 & 23 & … & $\cdots$ & 7 & 1 & $\cdots$ & $\cdots$. & 5 & $\cdots$ \\
\hline row... & 6 & $2+$ & 17 & 1 & $\cdots$ & & & & & & 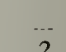 \\
\hline *Dickcissel ........ & 3 & 1 & 1 & 3 & + & 15 & 5 & + & 1 & 1 & 2 \\
\hline Brown thrasher & 3 & 1 & & 4 & 12 & $\cdots$ & 1 & 3 & 9 & 3 & 4 \\
\hline Mourning dove & 2 & + & 1 & 4 & 7 & 4 & 2 & 5 & 9 & 3 & $\cdots$ \\
\hline $\begin{array}{l}\text { American gold- } \\
\text { finch }\end{array}$ & 2 & 6 & 7 & $\cdots$ & $\cdots$ & 13 & 4 & 1 & $\cdots$ & 1 & 2 \\
\hline *Bobolink & 5 & 11 & 17 & $\cdots$ & 1 & $\cdots$ & $\cdots$ & $\cdots$ & $\cdots$ & $\cdots$ & 8 \\
\hline Bobwhite & 1 & $\cdots$ & & 1 & 5 & 2 & $\cdots-$ & + & 7 & 3 & 8 \\
\hline * Horned lark & 6 & $\cdots$ & 1 & 8 & $---\cdot$ & 13 & $\ldots$ & 2 & $\cdots$ & $\cdots$ & $-\cdots$ \\
\hline $\begin{array}{l}\text { Eastern king- } \\
\text { bird }\end{array}$ & 5 & 7 & 4 & + & 1 & $\cdots$ & 2 & 2 & + & $\cdots-$ & $\cdots$ \\
\hline Eastern bluebird & 1 & 3 & & 1 & 1 & 2 & 1 & 2 & 5 & 8 & $\ldots$. \\
\hline $\begin{array}{l}\text { Blue jay } \\
\text { Red-headed }\end{array}$ & 2 & 1 & 2 & 1 & 3 & $\cdots$ & 2 & 3 & + & 3 & $\cdots$ \\
\hline woodpecker & 3 & 1 & -.-- & 7 & 4 & -.-- & & 2 & + & $\ldots$ & $\ldots$ \\
\hline Common crow & 6 & $\cdots$ & $\cdots$ & 2 & 6 & --- & 2 & 1 & 1 &..- & $\ldots$ \\
\hline Orchard oriole & + & $-\cdots$ & $-\cdots$ & $\cdots$ & $-\cdots$ & 4 & $\cdots$ & 3 & + & 1 & 4 \\
\hline *Killdeer & 1 & 5 & .... & 1 & 3 & $\cdots$ & 2 & + & 1 & & 2 \\
\hline Chimney swift & 2 & & $\cdots$ & + & 2 & $\cdots$ & 5 & 1 & + & $\ldots$ & + \\
\hline *Vesper sparrow ... & 3 & 7 & 4 & $\cdots-$ & $\cdots$ & $\ldots$ & --- & $\cdots$ & $\cdots$ & & $\ldots$ \\
\hline Indigo bunting ....- & 1 & $\cdots$ & $\ldots$ & $\cdots$ & 1 & 2 & $-\cdots$ & + & + & + & t \\
\hline * Song sparrow ....... & & 4 & 2 & 1 & 3 & 2 & $\cdots$ & $\cdots--$ & $\ldots-$. & $\cdots$ & $\cdots$ \\
\hline $\begin{array}{l}\text { Mockingbird } \\
\text { Yellow-billed } \\
\text { cuckoo }\end{array}$ & - & $\ldots$. & $\cdots$ & $\ldots$ & --- & 4 & & 2 & 4 & 1 & $\cdots$ \\
\hline *ark sparrow & & & $\cdots$ & 1 & 1 & + & 2 & +5 & 1 & $\begin{array}{c}1 \\
\ldots\end{array}$ & $\cdots$ \\
\hline $\begin{array}{l}\text { * Upland plover } \\
\text { House wren }\end{array}$ & 3 & 2 & $\cdots$ & 3 & $\cdots$ & 6 & 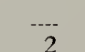 & + & 1 & $\cdots$ & $\cdots$ \\
\hline House wren & & 1 & $\cdots$ & 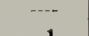 & $\cdots-$ & 6 & 2 & $\cdots \cdot$ & 1 & $\cdots \cdot$ & $\cdots$ \\
\hline $\begin{array}{l}\text { Baltumore oriole } \\
\text { Cardinal }\end{array}$ & + & 1 & $\cdots$ & 1 & $\cdots$ & $\begin{array}{l}2 \\
4\end{array}$ & + & + & $\cdots$ & 3 & -..- \\
\hline Sparrow hawk & + & 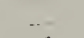 & -... & $\ldots$. & 1 & -4 & 1 & + & $\ldots$ & $\ldots$ & $\ldots$ \\
\hline Catbird & 3 & 1 & $\ldots$. & + & $\ldots$ & $\cdots .$. & 1 & + & 1 & $\cdots$. & $\ldots$. \\
\hline Bank swallow & 4 & .. & $\cdots$ & & 1 & .. . & $\cdots$ & $\cdots$ & 1 & $\cdots \cdot$ & -.- \\
\hline $\begin{array}{l}\text { Loggerhead } \\
\text { shrke }\end{array}$ & 1 & & $\ldots$. & 1 & 3 & & … & + & & $\ldots$ & .... \\
\hline Chipping sparrow & 3 & $\ldots$ & .... & & & $\ldots$. & $\ldots$. & 1 & 1 & $\ldots$ & $\ldots$ \\
\hline Yellowthroat .. & + & $\cdots .$. & $\ldots$ & & 1 & ... & $\ldots$ & 1 & 2 & ... & $\ldots$ \\
\hline Purple martin & .... & $\ldots$ & 1 & . & $\cdots$ & $\ldots .$. & $\ldots$. & 1 & 2 & $\ldots$ & $\cdots$. \\
\hline Bewick's wren & $\cdots$ & $\ldots$ & &.. & $\ldots$. & .. & $\ldots$ & + & + & 3 & $\ldots$ \\
\hline
\end{tabular}


studies and in all zones of the state. Seventeen species of birds were believed to breed in pastures, table 14 .
The meadowlarks appeared to increase their population densities between 1909 and 1957, particularly in the northern and

Table 14.-Continued

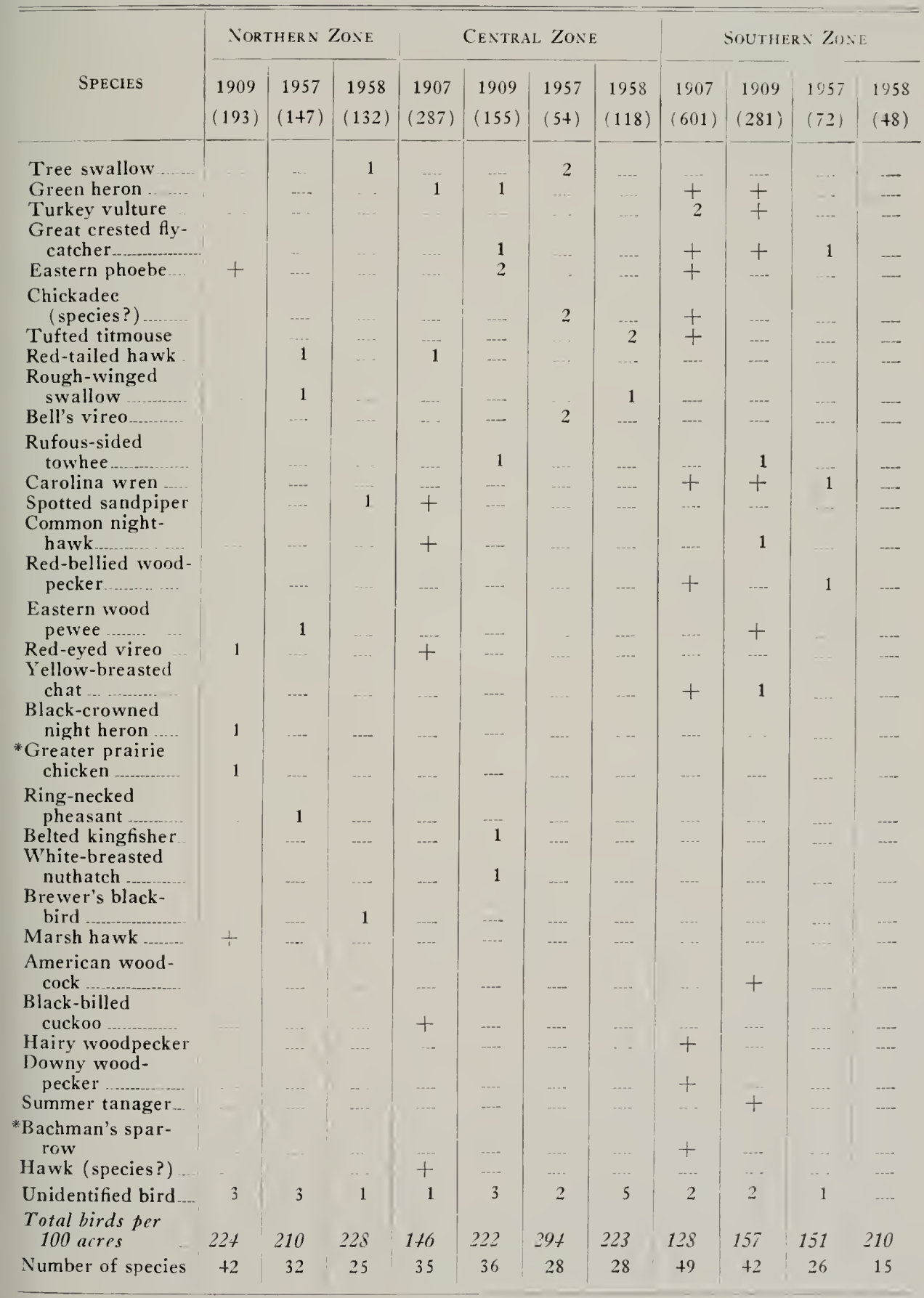




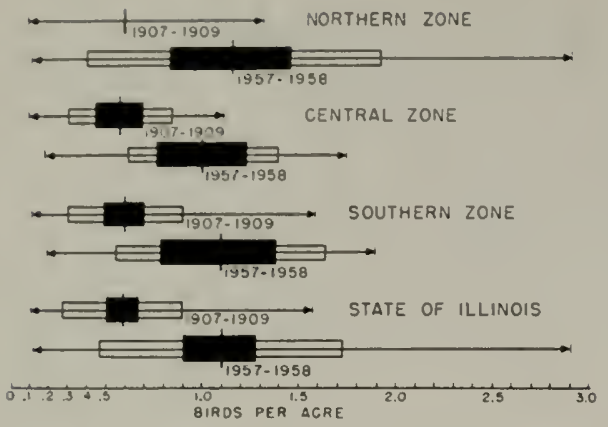

Fig. 17.-Populations of breeding species of birds censused in lllinois pastures in 1907-1909 and 1957-1958. The vertical line through each black rectangle indicates the mean, each open box one standard deviation on either side of the mean, each black rectangle two standard errors on either side of the mean, and each set of arrows the range.

central Illinois zones, as field sparrows did in the central and southern zones, table 14 and fig. 18. Other species showing increases both in relative rank and actual density were the redwinged blackbird (northern zone) and the savannah sparrow (northern zone), fig. 18 and table 14 .

\section{Ungrazed Grasslands (Summer)}

The acreage of ungrazed grasslands in Illinois is relatively small. We encoun- tered the habitat principally along railroad rights-of-way and road edges. IVe estimated that the area of this habitat declined from about 330,000 acres in 1907 to 218,000 in 1957 . Excluding roadside grass, 165 acres of this habitat were covered during summers of the two census periods in the nothern and southern zones of Illinois.

As a bird habitat, the ungrazed grasslands were closely allied to pastures and fallow fields; woody plants were almost completely lacking in the ungrazed grasslands. The cover of grasses and forbs in the ungrazed grasslands was taller (about 2-3 feet tall) than that in pastures and it was more dense.

Summer bird populations in ungrazed grasslands (excluding roadside grass) were comparable to those in other grassland habitats, with densities varying from approximately 1.2 to 3.9 birds per acre (119 to 386 birds per 100 acres, table 15) ; the densities in ungrazed grasslands were higher in the northern zone than in the southern zone.

At least 29 species of birds were identified in ungrazed grasslands in summer, table 15. Species common in this habitat were the redwinged blackbird and the eastern and western meadowlarks.

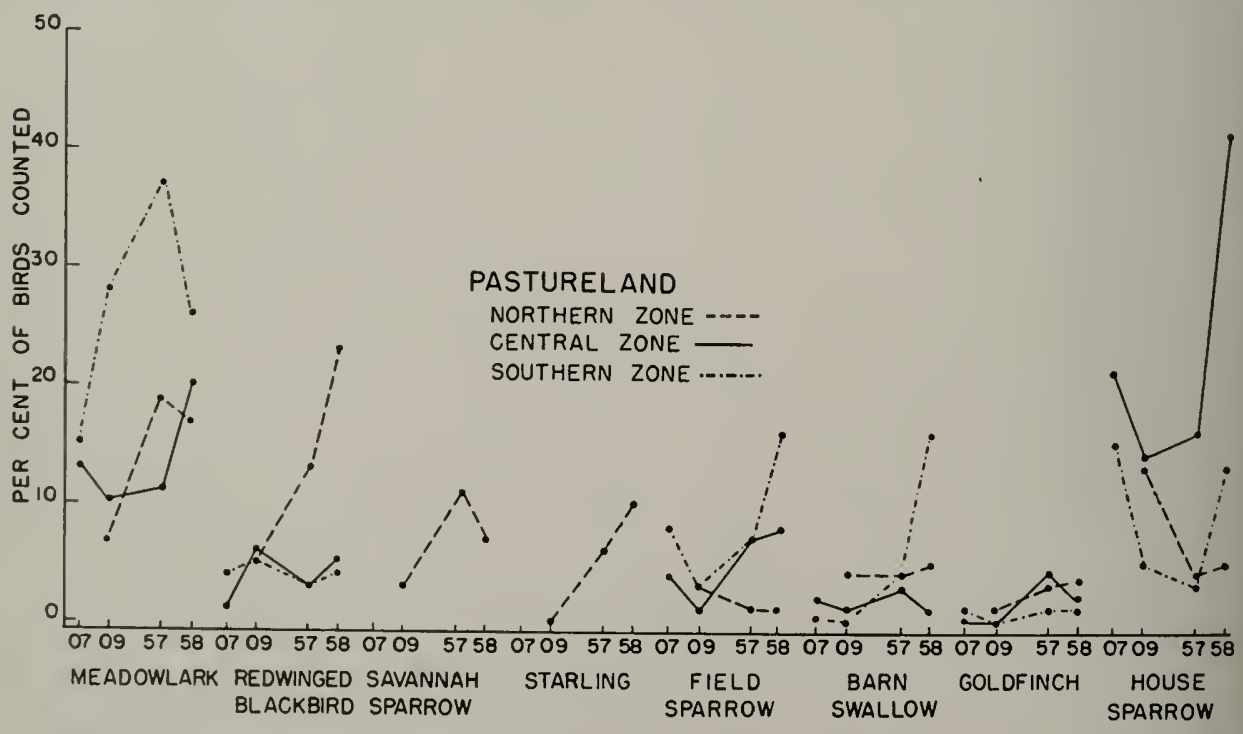

Fir. 18.- Relative abundance of common species of birds censused in pastureland of the northern, central, and southern zones of Illinois in the summers of 1907, 1909, 1957, and 1958 . Only those species are included that showed changes in relative abundance (per cent of all birds counted in pastureland) between 1909 and 1957. 
Table 15.-Summer avifauna in Illinois ungrazed grasslands (birds per 100 acres) as determined by strip censuses in two zones (open stands only; no roadside or edge grass areas included in this table). Figures in parentheses indicate numbers of acres censused; $*$ indicates breeding species in this habitat.

\begin{tabular}{|c|c|c|c|c|c|c|}
\hline \multirow[b]{2}{*}{ Species } & \multicolumn{3}{|c|}{ Northern Zone } & \multicolumn{3}{|c|}{ SOUTHERN ZONE } \\
\hline & $\begin{array}{l}1909 \\
(15)\end{array}$ & $\begin{array}{l}1957 \\
(10)\end{array}$ & $\begin{array}{l}1958 \\
(49)\end{array}$ & $\begin{array}{l}1907 \\
(33)\end{array}$ & $\begin{array}{l}1957 \\
(20)\end{array}$ & $\begin{array}{l}1958 \\
(38)\end{array}$ \\
\hline * Meadowlark (species?) & +7 & .... & 66 & 67 & 115 & 37 \\
\hline * Redwinged blackbird & 88 & 19 & +1 & 36 & 30 & \\
\hline Mourning dove & 7 & $\ldots$ & 98 & 12 & ...- & 13 \\
\hline Horned lark & $\ldots$ & $\cdots$ & 113 & $\ldots$ & & 13 \\
\hline Common grackle & 20 & 9 & -... & $\ldots$ & 15 & 21 \\
\hline *Bobolink & $5+$ & 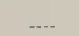 & ..... & $\ldots$. & .... & $\ldots$ \\
\hline Barn swallow & 27 & 9 & 2 & $\ldots$. & $\ldots$ & 13 \\
\hline Swamp sparrow & .... & 38 & $\ldots$ & ... & & \\
\hline Field sparrow & $\ldots$ & & & $\ldots$. & 25 & 5 \\
\hline American goldfinch & ... & 19 & 10 & $\ldots$ & $\ldots$ & $\ldots$. \\
\hline Song sparrow & 20 & 9 & & $\ldots .$. & & \\
\hline * Grasshopper sparrow & -... & & + & $\ldots$ & 15 & 5 \\
\hline Brown-headed cowbird & $\ldots$. & 19 & 2 & $\ldots$ & $\cdots$ & $\cdots$ \\
\hline House sparrow & .... & $\ldots$ & 4 & 9 & 5 & $\ldots$ \\
\hline *Dickcissel & $\ldots-$. & $\ldots$ & + & 6 & 5 & 3 \\
\hline Robin & 7 & 9 & & $\ldots$ & $\ldots$. & \\
\hline * Bobwhite & $\ldots$ & & 6 & 3 & $\ldots$ & 3 \\
\hline Blue jay & $\ldots$ & 9 & $\ldots$ & 3 & -. & $\cdots$ \\
\hline Common crow & & & 10 & $\ldots$. & $\ldots$ & $\ldots$ \\
\hline Yellow-shafted ficker & 7 & $\ldots$ & 2 & ... & $=$ & $\ldots$. \\
\hline Indigo bunting & $\ldots$ & $\ldots$ & & .... & 5 & 3 \\
\hline * Savannah sparrow & $\ldots$. & $\ldots$ & 8 & ... & & $\ldots$ \\
\hline Common egret & $\ldots$ & $\ldots$ & $\ldots$. & $\ldots$ & 5 & $\ldots$ \\
\hline American redstart & $\ldots$ & $\ldots$. & $\ldots$ & $\cdots$ & 5 & $\ldots$ \\
\hline Red-headed woodpecker & $\ldots$ & & 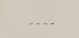 & 3 & ... & $\cdots$ \\
\hline Starling & $\ldots$ & $\ldots$ & & $\ldots$ & $\ldots$. & 3 \\
\hline Killdeer & $\ldots$ & $\ldots$ & 2 & $\ldots$ & $\ldots$ & $\ldots$ \\
\hline Bank swallow & $\ldots$ & $\ldots$. & 2 & ...- & ... & $\ldots$ \\
\hline Short-billed marsh wren. & $\ldots$ & $\ldots$ & 2 & $\cdots$ & .... & $\ldots$ \\
\hline Unidentified bird & 7 & 38 & 10 & $\ldots .$. & 5 & \\
\hline Total birds per 100 acres & 287 & 178 & 386 & 139 & 230 & 119 \\
\hline Number of species & 9 & 9 & 17 & 8 & 10 & 11 \\
\hline
\end{tabular}

\section{Fallow Fields (Summer)}

As we define the habitat, fallow fields are fields that have been cultivated and then left unused for a year or longer. Such fields support a variety of weeds and grasses that form a fairly dense cover to a height of $2-+$ feet. Small shrubs may be found scattered in the older fallow fields, but woody plants are not a dominant feature of the habitat. As a bird habitat, fallow land probably bears closest resemblance to pasture or ungrazed grassland.

Agricultural census figures and our own census data indicate that the area of fallow land in Illinois declined from about 1,500,000 acres in 1909 to $1,000,000$ in 1957. Logically, acreage of fallow lands should diminish as a swelling human population increases the demand for cultivated land. In Illinois, largest acreages of this habitat were found in the southern zone; smallest acreages were in the intensively cultivated area of east central Illinois. In the study periods, 682 acres of fallow land were censused, table 3.

Population levels of birds in fallow fields in the southern zone did not change greatly in the half century after 1909, table 16. As bird habitat, the fallow land censused was rich in numbers and species, being about comparable to pastureland. The numbers of birds per acre for all census summers in the southern zone ranged from 1.3 to 1.7. Among the breeding spe- 
Table 16.- Statistical data on summer bird populations in lllinois fallow fields as determined by strip censuses in the southern zone. Data are (1) from all fallow fields censused in this zone and (2) from sample areas (each 10 acres or more) in these fields. The data from sample areas are for breeding species only.

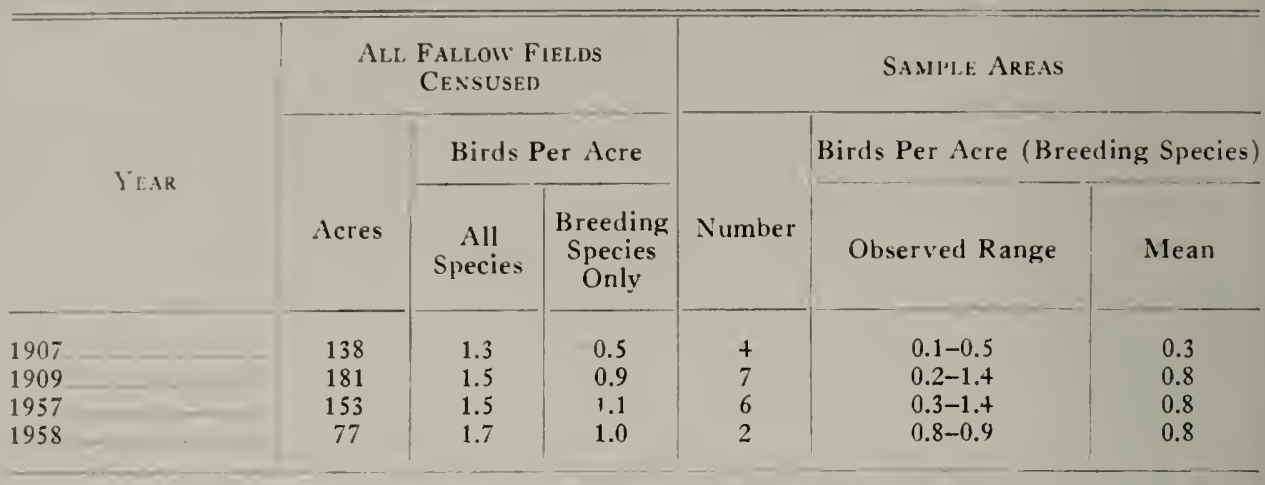

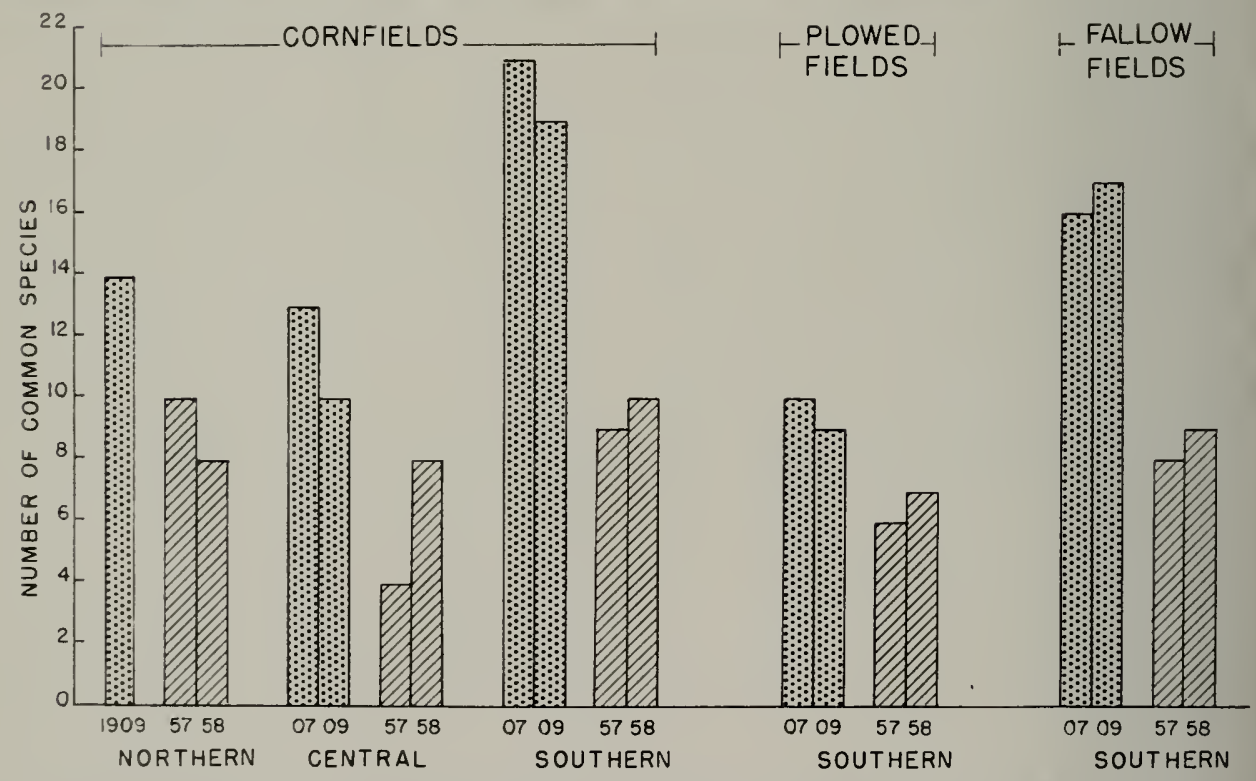

Fig. 19.-Numbers of common bird species (those comprising 85 per cent of the population) in three open-field habitats of Illinois in 1907-1909 and 1957-1958.

cies, which usually constituted at least one-half of the total population, the numbers ranged from 0.5 to 1.1 birds per acre.

At least 50 species of birds were identified in this habitat in summer in the three zones of Illinois. Only the eastern meadowlark and the mourning dove were recorded in all zones in all census years, table 17 . 'The redwinged blackbird, field sparrow, and grackle occurred with high frequency in this habitat. In the southern zone, population increases were noted in this habitat for the mourning dove, red- winged blackbird, dickcissel, and grackle. The loss of variety in avifauna (after 1909), a loss that characterized other open-field habitats, was apparent also in the fallow field avifauna, fig. 19.

\section{Mixed Hayfields (Summer)}

To point out possible differences in the bird populations of various types of hay crops, we segregated data on hayfields of mixed grasses and legumes (called mixed hay) from those of the relatively pure stands of alfalfa, red clover, and sweet 
Table 17.-Summer avifauna in Illinois fallow fields (birds per 100 acres) as determined by strip censuses in the three zones. Figures in parentheses indicate numbers of acres censused; * indicates breeding species in this habitat.

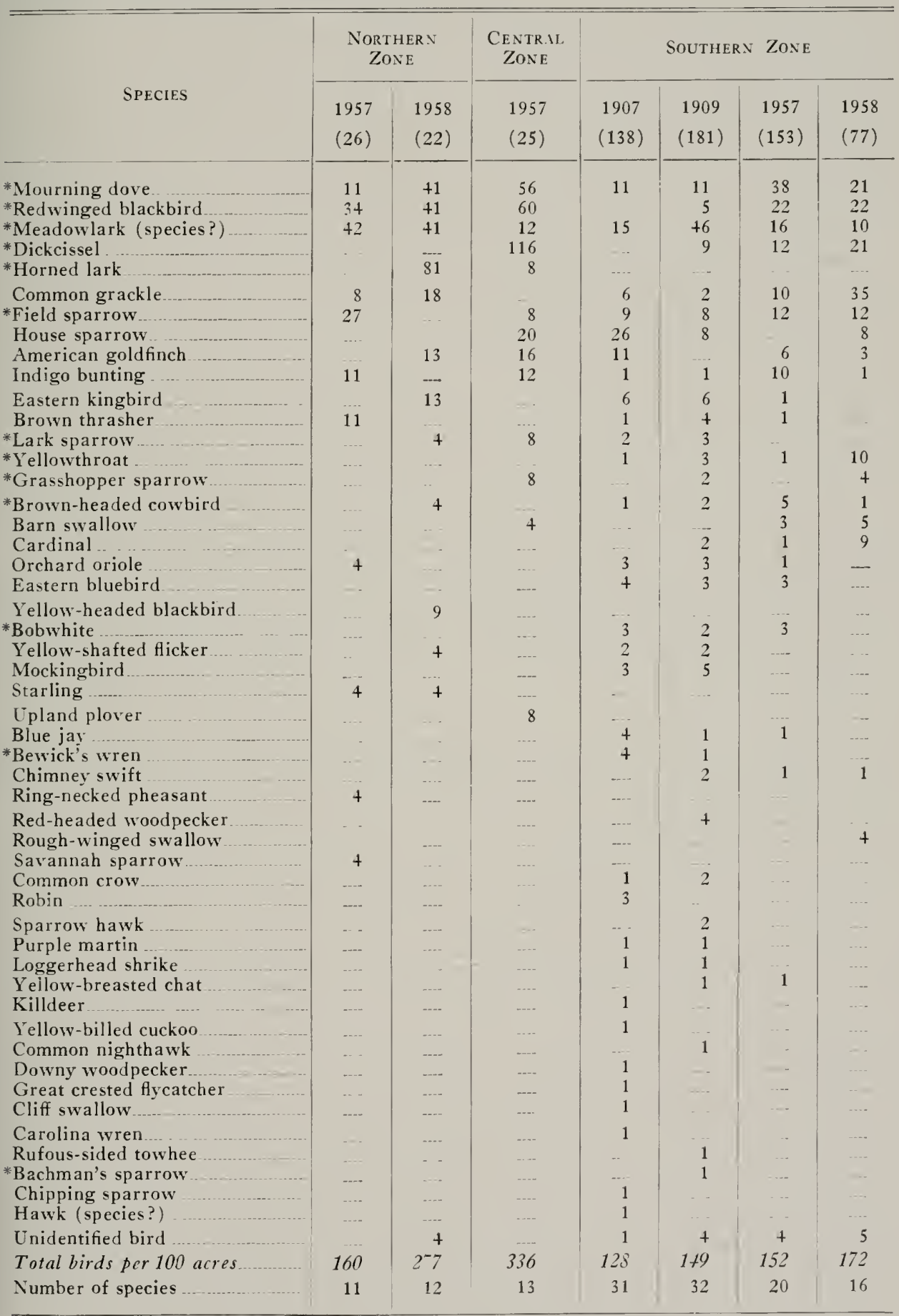


clover. The present account concerns mixed hay. During the two study periods, 1,212 acres of this habitat were censused in summer, less than 400 acres of it in 1957-1958, table 3.

The strip census data and published agricultural records indicate that the total acreage of mixed hay in lllinois (over 2,500,000 acres) was about the same in 1907-1909 as in 1957-1958; the mixed hay acreage declined in the north and increased in the south.

Mixed hay usually forms a dense cover 2 to 3 feet in height at maturity and is grenerally composed of various mixtures of grasses (timothy, brome, and wild grasses) and legumes (red clover, sweet clover, and alfalfa).

As a bird habitat, mixed hay was fairly rich in species and very rich in numbers of birds, figs. 22-2t and tables 18 and 19. At least $1+$ species of birds were found to nest in this habitat, table 19. As fig. 5 shows, field-to-field variation of bird populations in this habitat was high. Average densities of birds (all species) per acre in mixed hayfields in summer ranged from 1.1 to 8.2 birds per acre; the numbers of birds per acre in successive census years in one zone ranged from 1.8 in 1957 to 8.2 in 1958, in the central zone, table 18 .
Such high variability and the relatively small samples in the later census period make conclusions tenuous, but bird populations in northern zone hayfields appeared to be conspicuously higher in 19571958 than in 1909.

Average densities of breeding-bird populations in mixed hayfields ranged from 0.5 to 7.1 birds per acre, table 18 . These populations were usually highest in northern Illinois, and almost invariably they were higher in the later than in the early years. The numbers of breeding birds per acre in 1907-1909 ranged from 0.5 to 1.4 ; in $1957-1958$ the range was from 0.8 to 7.1 , table 18 .

This apparent increase in population density between 1909 and 1958 may be attributable to a few species. Of the 57 or more species found in summer havfields, table 19 , only the eastern meadowlark was reported in all census years and in all zones, though the redwinged blackbird, dickcissel, and grasshopper sparrow were reported with very high frequencr. Common hayfield birds are listed in tables 20 , 21 , and 22 . In the havfield fauna, the meadowlarks were found to be increasingly important from northern to southern latitudes in 1907-1909, as well as in recent census years. In northern Illinois,

Table 18.-Statistical data on summer bird populations in mixed hayfields of Illinois as determined by strip censuses in the three zones. Data are (1) from all mixed hayfields censused and (2) from sample areas (each 4 acres or more) in these fields. The data from sample areas are for breeding species only.

\begin{tabular}{|c|c|c|c|c|c|c|c|c|c|}
\hline \multirow{3}{*}{$\begin{array}{l}\text { ZONE } \\
\text { AND } \\
\text { YEAR }\end{array}$} & \multicolumn{3}{|c|}{ All Mixed Hayfields } & \multicolumn{6}{|c|}{ SAMPLE AREAS } \\
\hline & \multirow[b]{2}{*}{ Acres } & \multicolumn{2}{|c|}{ Birds Per Acre } & \multirow[b]{2}{*}{$\begin{array}{l}\text { Num- } \\
\text { ber }\end{array}$} & \multicolumn{5}{|c|}{ Birds Per Acre (Breeding Species Only) } \\
\hline & & $\begin{array}{c}\text { All } \\
\text { Species }\end{array}$ & $\begin{array}{c}\text { Breeding } \\
\text { Species } \\
\text { Only }\end{array}$ & & Range & Mean & $\begin{array}{l}\text { Standard } \\
\text { Deviation }\end{array}$ & $\begin{array}{c}\text { Standard } \\
\text { Error }\end{array}$ & $\begin{array}{c}\text { Mean } \pm \\
\text { 2 S.E. }\end{array}$ \\
\hline \multicolumn{10}{|l|}{ Northern } \\
\hline 1909 & 175 & 2.3 & 1.3 & 7 & $0.4-2.6$ & $1 .+$ & 0.7 & 0.3 & $0.8-2.0$ \\
\hline 1957 & 91 & +.0 & 3.5 & 7 & $1.7-6.4$ & 3.9 & 1.6 & 0.6 & $2.7-5.1$ \\
\hline 1958 & 30 & 6.2 & 4.2 & 2 & $\ldots$ & $\ldots$. & $\ldots$ & $\ldots$ & .... \\
\hline \multicolumn{10}{|l|}{ Central } \\
\hline 1907 & 60 & 1.1 & 0.5 & 5 & $0.2-1.3$ & 0.7 & 0.4 & 0.2 & $0.3-1.1$ \\
\hline 1909 & 65 & 2.4 & 1.4 & 5 & $0.7-2.3$ & 1.5 & 0.7 & 0.3 & $0.9-2.1$ \\
\hline 1957. & 55 & 1.8 & 1.6 & + & $0.1-3.6$ & 2.3 & $\ldots$ & $-\ldots$ & -.... \\
\hline 1958 & 24 & 8.2 & 7.1 & 3 & $0.9-9.3$ & 5.1 & -..- & $\ldots$ & $\ldots$ \\
\hline \multicolumn{10}{|l|}{ Southern } \\
\hline 1907 & 330 & 1.6 & 1.1 & 20 & $0.0-2.9$ & 0.9 & 0.7 & 0.1 & $0.7-1.1$ \\
\hline 1909 & $20 t$ & 1.5 & 1.0 & 11 & $0.5-1.7$ & 1.0 & 0.4 & 0.1 & $0.8-1.2$ \\
\hline 1957 & 33 & 1.1 & 0.8 & 3 & $0.2-1.1$ & 0.6 & $-\cdots$ & --- & -.- \\
\hline 1958 & 26 & 3.1 & 2.5 & 1 & -.. & ...- & $\ldots$ & $\ldots$. & $\ldots$ \\
\hline
\end{tabular}


Table 19.- Summer avifauna in mixed hayfields of Illinois (birds per 100 acres) as determined by strip censuses in the three zones. Figures in parentheses indicate numbers of acres censused; * indicates breeding species in this habitat.

\begin{tabular}{|c|c|c|c|c|c|c|c|c|c|c|c|}
\hline \multirow[b]{2}{*}{ SPECIES } & \multicolumn{3}{|c|}{ NORTHERN ZONE } & \multicolumn{4}{|c|}{ Central Zone } & \multicolumn{4}{|c|}{ SOUTHERN ZONE } \\
\hline & $\begin{array}{l}1909 \\
(175)\end{array}$ & $\begin{array}{l}1957 \\
(91)\end{array}$ & $\begin{array}{l}1958 \\
(30)\end{array}$ & $\begin{array}{l}1907 \\
(60)\end{array}$ & $\begin{array}{l}1909 \\
(65)\end{array}$ & $\begin{array}{l}1957 \\
(55)\end{array}$ & $\begin{array}{l}1958 \\
(24)\end{array}$ & $\begin{array}{l}1907 \\
(330)\end{array}$ & $\begin{array}{c}1909 \\
(204)\end{array}$ & $\begin{array}{l}1957 \\
(33)\end{array}$ & $\begin{array}{l}1958 \\
(26)\end{array}$ \\
\hline $\begin{array}{c}\text { *Red winged } \\
\text { blackbird }\end{array}$ & 8 & 230 & 220 & 7 & 9 & 31 & 249 & 22 & 12 & $-\cdots$ & 121 \\
\hline $\begin{array}{r}{ }^{*} \text { Meadowlark } \\
\text { (species?) }\end{array}$ & 29 & 25 & 50 & 13 & 53 & 33 & 69 & 57 & & & \\
\hline *Dickcissel & 25 & 10 & & 15 & 50 & 74 & 212 & 23 & $\begin{array}{l}59 \\
21\end{array}$ & $\begin{array}{r}61 \\
6\end{array}$ & $\begin{array}{l}7+ \\
35\end{array}$ \\
\hline * Bobolink & 53 & 75 & 60 & & $\cdots$ & 2 & 37 & $\cdots$ & & ... & \\
\hline sparrow & 9 & 1 & $\cdots$. & 15 & 18 & $1+$ & 122 & + & 1 & 6 & 4 \\
\hline House sparrow & +5 & 13 & 67 & 2 & 35 & 2 & 77 & $\begin{array}{r}12 \\
6\end{array}$ & + & & .... \\
\hline $\begin{array}{l}\text { Common grackle } \\
\text { Mourning dove }\end{array}$ & $\begin{array}{l}8 \\
5\end{array}$ & $\begin{array}{r}7 \\
\ldots-\end{array}$ & $\begin{array}{l}67 \\
17\end{array}$ & 13 & $\begin{array}{r}11 \\
6\end{array}$ & & $\cdots$ & $\begin{array}{l}6 \\
5\end{array}$ & 1 & 18 & \\
\hline $\begin{array}{l}\text { *avannah spar- } \\
\text { row. }\end{array}$ & 2 & $\cdots$ & 47 & 18 & 6 & 5 & $\cdots$ & 3 & 7 & 3 & 12 \\
\hline Barn swallow & 2 & 3 & 7 & .... & 9 & 4 & + & -... & -... & 6 & 8 \\
\hline $\begin{array}{l}\text { "Bobwhite } \\
\text { Yellow-shafted } \\
\text { flicker }\end{array}$ & 1 & --- & -..- & $\cdots$ & $\ldots$ & $\cdots$ & 8 & 2 & 6 & 9 & 16 \\
\hline $\begin{array}{c}* \text { Brown-headed } \\
\text { cowbird }\end{array}$ & 2 & 1 & 20 & -.-. & 5 & -... & .... & 1 & 1 & $\cdots$ & -- \\
\hline $\begin{array}{l}\text { American } \\
\text { gold finch } \\
\text { Robin }\end{array}$ & $\begin{array}{l}2 \\
2\end{array}$ & $\begin{array}{l}3 \\
1\end{array}$ & $\begin{array}{r}10 \\
7\end{array}$ & $\begin{array}{l}3 \\
7\end{array}$ & $\cdots$ & $\cdots$ & & $\begin{array}{l}1 \\
1\end{array}$ & & $-\cdots-$ & 8 \\
\hline $\begin{array}{l}\text { Robin } \\
\text { Brown thrasher }\end{array}$ & 2 & 1 & $\begin{array}{r}7 \\
-\cdots\end{array}$ & 7 & 3 & $\ldots$ & + & $\begin{array}{l}1 \\
1\end{array}$ & $\begin{array}{l}2 \\
6\end{array}$ & $\cdots$ & $\ldots$ \\
\hline $\begin{array}{l}\text { Brerver's black- } \\
\text { bird }\end{array}$ & --- & 1 & 17 & & 3 & 2 & --- & --. & 3 & $\cdots$ & $\cdots-$ \\
\hline Common crow & -... & 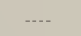 & .... & .... & 15 & $\ldots$ & .... & ..... & & .... & $\ldots$ \\
\hline Eastern kingbird & 3 & 1 & 3 & 2 & $\ldots-$ & -..- & $\ldots$. & 1 & + & $\ldots$ & -..- \\
\hline $\begin{array}{l}\text { Swamp sparrow. } \\
\text { Chimney swift }\end{array}$ & 1 & 1 & 13 & -..- & $\cdots$ & .... & .... & + & .... & -... & -..- \\
\hline $\begin{array}{l}\text { Chimney, swift } \\
\text { *Henslow's spar- } \\
\text { row }\end{array}$ & 7 & & $\cdots-$ & & $\begin{array}{l}1 \\
1\end{array}$ & $\cdots$ & 12 & 5 & $\cdots$ & --- & -... \\
\hline Song sparrow & 3 & $-\cdots-$ & 7 & 2 & 1 & -- & .... & $-\cdots$ & $\ldots .$. & .... & ... \\
\hline $\begin{array}{l}\text { Killdeer } \\
\text { Horned lark }\end{array}$ & 3 & 1 & $\begin{array}{r}7 \\
---\end{array}$ & $\begin{array}{l}2 \\
2\end{array}$ & $\cdots$ & $-\cdots$ & $\ldots$ & + & $\cdots \cdot$ & $\cdots$. & ... \\
\hline $\begin{array}{l}\text { *Short-billed } \\
\text { marsh wren }\end{array}$ & 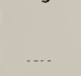 & & 10 & - & & $\cdots$ & & & & - & $\cdots$ \\
\hline Yellowthroat & -- & 2 & $\ldots .$. & $\ldots$ & 1 & $\ldots$ & -..- & 2 & 1 & .... & 4 \\
\hline *Vesper sparrow. & 3 & 3 & 3 & $\cdots$ & $\cdots$ & -..- & .... & $\cdots$ & $\cdots-$ & $-\cdots$ & $\cdots$ \\
\hline $\begin{array}{l}\text { Field sparrow } \\
\text { Common night- } \\
\text { hawk }\end{array}$ & 1 & $--\cdot$ & $\ldots$ & 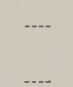 & 1 & $\ldots$ & $\ldots$ & 3 & $\begin{array}{r}+ \\
+\end{array}$ & $\ldots$ & $\cdots$ \\
\hline $\begin{array}{l}\text { Ruby-throated } \\
\text { hummingbird } \\
\text { Purple martin }\end{array}$ & -- & & & & -... & .... & 4 & & .... & -..- & + \\
\hline $\begin{array}{l}\text { Purple martin } \\
\text { Bachman's spar- } \\
\text { row }\end{array}$ & -... & $-\cdots$ & --- & -..- & -... & -..- & --. & -..- & .... & -..- & 8 \\
\hline $\begin{array}{l}\text { Black tern } \\
\text { Red-headed wood- } \\
\text { pecker. }\end{array}$ & 1 & -.- & 7 &.-- & $\ldots$. & $\cdots$ & $\ldots .-$ &.-- & --- & --- & $-\cdots$ \\
\hline Indigo bunting & 1 & + & & $\cdots$ & 2 & $\cdots$ & -..- & & 1 & $\cdots$ & $\cdots$ \\
\hline $\begin{array}{l}\text { Sparrow hawk } \\
{ }^{*} \text { Ring-necked }\end{array}$ & & & 3 & & -- & $\ldots$. & $\ldots$ & 1 & 1 & -..- & $\cdots$. \\
\hline pheasant & --.- & - & 3 & $\ldots$ & $\cdots$. & $\cdots$. & -... & 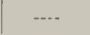 & $\cdots$ & -.- & -... \\
\hline
\end{tabular}


Table 19.-Continued

\begin{tabular}{|c|c|c|c|c|c|c|c|c|c|c|c|}
\hline \multirow[b]{2}{*}{ SPECIES } & \multicolumn{3}{|c|}{ Northern ZONE } & \multicolumn{4}{|c|}{ Central ZONe } & \multicolumn{4}{|c|}{ SOUTHERN ZONE } \\
\hline & $\begin{array}{l}1909 \\
(175)\end{array}$ & $\begin{array}{l}1957 \\
(91)\end{array}$ & $\begin{array}{l}1958 \\
(30)\end{array}$ & $\begin{array}{l}1907 \\
(60)\end{array}$ & $\begin{array}{l}1909 \\
(65)\end{array}$ & $\begin{array}{l}1957 \\
(55)\end{array}$ & $\begin{array}{l}1958 \\
(24)\end{array}$ & $\begin{array}{c}1907 \\
(330)\end{array}$ & $\begin{array}{l}1909 \\
(20+)\end{array}$ & $\begin{array}{l}1957 \\
(33)\end{array}$ & $\begin{array}{l}1958 \\
(26)\end{array}$ \\
\hline Traill's flycatcher & - & $\ldots$ & --- & -... & 3 & -..- & … & & & $\cdots$ & .... \\
\hline Orchard oriole & $\cdots$ & - & - & - & $\cdots$. & $-\cdots$ & $\cdots$. & 1 & 2 & .... & $\ldots$ \\
\hline $\begin{array}{l}\text { Lastern bluebird } \\
\text { Loggerhead }\end{array}$ & 1 & -.-- & $\cdots$ & --- & -.- & - & -..- & + & 1 & $\cdots \cdot$ & --- \\
\hline $\begin{array}{l}\text { shrike } \\
\text { Red-shouldered } \\
\text { hawk }\end{array}$ & - & --- & $\cdots$ & 1 & --- & --- & -..- & 1 & -- & -- & --- \\
\hline $\begin{array}{l}\text { *Greater prairie } \\
\text { chicken }\end{array}$ & 1 & .... & $\ldots$ & -..- & --- & $\ldots$ & $\cdots$. & -..- & .... & $\ldots$ & -..- \\
\hline $\begin{array}{l}\text { Yellow-billed } \\
\text { cuckoo }\end{array}$ & -.-- & $\ldots$ & $-\ldots$ & -.. & -- & - & $\ldots$ & 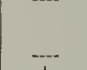 & 1 & $\cdots$ & .. - \\
\hline Blue jay . .... & -..- & 1 & - & $\ldots$ &.-- & $\ldots$ & -- & + & + & $-\cdots-$ & $\ldots .$. \\
\hline Mockingbird & $\cdots$ & 1 & --- & -.- & --- & - & --- & 1 & $\cdots-\cdot$ & $\cdots$ & --- \\
\hline Catbird & --- & 1 & --- & -- & --- & -- & $\cdots$ & -... & $\cdots$ & $\cdots$ & $\cdots \cdot$ \\
\hline $\begin{array}{l}\text { Lark sparrow } \\
\text { Green heron }\end{array}$ & $\ldots$ & $\cdots$ & $\cdots$ & 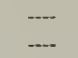 & -.- & 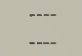 & +- & $\begin{array}{r}1 \\
-\cdots\end{array}$ & + & $\cdots$ & $\cdots$ \\
\hline $\begin{array}{l}\text { Turkey vulture } \\
\text { Downy wood- } \\
\text { pecker }\end{array}$ &.--- & - & --- & - & --- & $\cdots$ & --- & $\cdots$ & + & -.- & $\cdots$ \\
\hline $\begin{array}{l}\text { Great crested } \\
\text { Hycatcher }\end{array}$ & - & --- & $\cdots-\cdot$ & --- & ---- & - & ---- & --- & + & $\ldots$ & ... \\
\hline $\begin{array}{l}\text { Easteru phoebe } \\
\text { Cardinal }\end{array}$ & $\ldots$. & $\ldots$ & $\cdots$ & --- & --.- & -.- & -- & + & + & -- & -... \\
\hline $\begin{array}{l}\text { Melospiza } \\
\quad \text { (species?) }\end{array}$ & $\cdots$ & & $\cdots$ & --- & $\ldots$ & --- & --- & $\cdots$ & $\cdots$ & $-\cdots-$ & $\cdots$ \\
\hline Unidentified bird & 3 & 10 & 27 &.--- & 3 & 5 & 4 & 3 & 4 & 3 & 4 \\
\hline $\begin{array}{l}\text { Total birds per } \\
100 \text { acres }\end{array}$ & 229 & $40 t$ & 622 & 114 & 244 & 177 & 822 & 160 & 146 & 112 & 310 \\
\hline Number of species & 27 & 23 & 23 & 16 & 20 & 10 & 13 & 30 & 29 & 7 & 13 \\
\hline
\end{tabular}

meadowlarks appeared to be relatively less common in the hayfield fauna in 1957 than in 1909, tables 20 and 21 , despite the recent spread of the western meadowlark into the northern half of the state. The redwinged blackbird population increased dramatically, hoth in the absolute terms of birds per acre, table 19, and relative to other species, tables 20 and 21 . The bobolink population appeared to increase in the northern and central zones as the dickcissel did in the central zone.

Some impression of the year-to-year variation in the common summer avifauna of hayfields may be obtained from data presented in table 22 . The most common species showed only slight variation in rank of abundance between 1907 and 1909.

\section{Clover Fields (Summer)}

Relatively pure stands of red clover and sweet clover are important open-field habitats for birds. The random censuses of birds indicated that the acreage of Illinois land in clover and alfalfa increased in the half century after 1909 , but as bird habitats the crops themselves did not change.

Red Clover.-Red clover forms very dense cover 1-2 feet tall. In central Illinois, the crop is usually mowed by midJune. Harvest dates are 1-2 weeks earlier in southern lllinois and 1-2 weeks later in northern Illinois. If left uncut, the plants finish blooming and begin to dry and fall in July and August.

We estimated that hayfields in which red clover predominated accounted for about 5+4,000 acres in 1907 and 1,100,000 acres in 1957. In summers of the two census periods, 446 acres of red clover were covered, table 3 . This habitat boasted a high population density of birds, usually exceeding that for pasture and other grassland habitats, figs. 22-24. Population densities for all years and zones censused varied from 1.9 to 5.5 birds per 
Table 20.-Common birds (species making up approximately 85 per cent of birds counted in strip censuses) in fields of mixed hay in the three zones of Illinois, summer, 1909.

\begin{tabular}{|c|c|c|c|c|c|}
\hline \multicolumn{2}{|l|}{ Northern ZoNe } & \multicolumn{2}{|l|}{ Central Zone } & \multicolumn{2}{|l|}{ SOUTHERN ZONE } \\
\hline Species & $\begin{array}{l}\text { Per } \\
\text { Cent }\end{array}$ & Species & $\begin{array}{l}\text { Per } \\
\text { Cent }\end{array}$ & Species & $\begin{array}{l}\text { Per } \\
\text { Cent }\end{array}$ \\
\hline Bobolink & 23 & Meadowlark (species?) & 21 & Eastern meadowlark & 38 \\
\hline House sparrow & 20 & Dickcisse] & 20 & Dickcissel & 14 \\
\hline Meadowlark (species?) & 13 & House sparrow & 14 & Redwinged blackbird. & 8 \\
\hline Dickcissel & 11 & Grasshopper sparrow & 7 & Mourning dove & 5 \\
\hline Grasshopper sparrow & + & Yellow-shafted flicker & 6 & Brown thrasher. & + \\
\hline Redwinged blackbird & 3 & Common crow & 6 & Bobwhite & + \\
\hline Coinmon grackle & 3 & Common grackle & + & Field sparrow & 3 \\
\hline Chimney swift & 3 & Barn swallow & + & Eastern kingbird & 3 \\
\hline Vellow-shafted flicker & 3 & Redwinged blackbird & 4 & House sparrow & 3 \\
\hline Mourning dove & 2 & & & $\begin{array}{l}\text { Upland plover } \\
\text { Red-headed woodpecker }\end{array}$ & $\begin{array}{l}2 \\
2\end{array}$ \\
\hline Total per cent & 85 & Total per cent & 86 & Total per cent & $s 6$ \\
\hline Number of species & 10 & Number of species & 9 & Number of species & 11 \\
\hline
\end{tabular}

Table 21.-Common birds (species making up approximately 85 per cent of birds counted in strip censuses) in mixed hayfields in the three zones of Illinois, summer, 1957.

\begin{tabular}{|c|c|c|c|c|c|}
\hline \multicolumn{2}{|l|}{ Northern Zone } & \multicolumn{2}{|l|}{ Central Zone } & \multicolumn{2}{|l|}{ SOUTHERn ZONE } \\
\hline Speces & $\begin{array}{c}\text { Per } \\
\text { Cent }\end{array}$ & Species & $\begin{array}{c}\text { Per } \\
\text { Cent }\end{array}$ & Species & $\begin{array}{c}\text { Per } \\
\text { Cent }\end{array}$ \\
\hline Redwinged blackbird & 57 & Dickcissel & +3 & Fastern meadowlark & $5+$ \\
\hline Bobolink & 19 & Meadowlark (species?) & $\begin{array}{l}+2 \\
19\end{array}$ & $\begin{array}{l}\text { Common grackle. } \\
\text { Com }\end{array}$ & $\begin{array}{l}3+ \\
16\end{array}$ \\
\hline Meadowlark (species?) & 6 & Redwinged blackbird & 17 & Bobwhite & 8 \\
\hline House sparrow & 3 & Grasshopper sparrow & 8 & $\begin{array}{l}\text { Barn swallow } \\
\text { Dickcissel... } \\
\text { Grasshopper sparrosy }\end{array}$ & $\begin{array}{l}5 \\
5 \\
5\end{array}$ \\
\hline Total per cent & $\$ 5$ & Total per cent & 86 & $\begin{array}{l}\text { Grasshopper sparrow } \\
\text { Total per cent }\end{array}$ & $93 *$ \\
\hline Number of species & + & Number of species & + & Number of species & $6 *$ \\
\hline
\end{tabular}

* Four species made up 83 per cent of the birds counted; six species were included here, three with 5 per cent each.

Table 22.-Common birds (species making up approximately 85 per cent of birds counted in strip censuses) in mixed hayfields in the soutbern zone of Illinois, summers, 1907 and 1909.

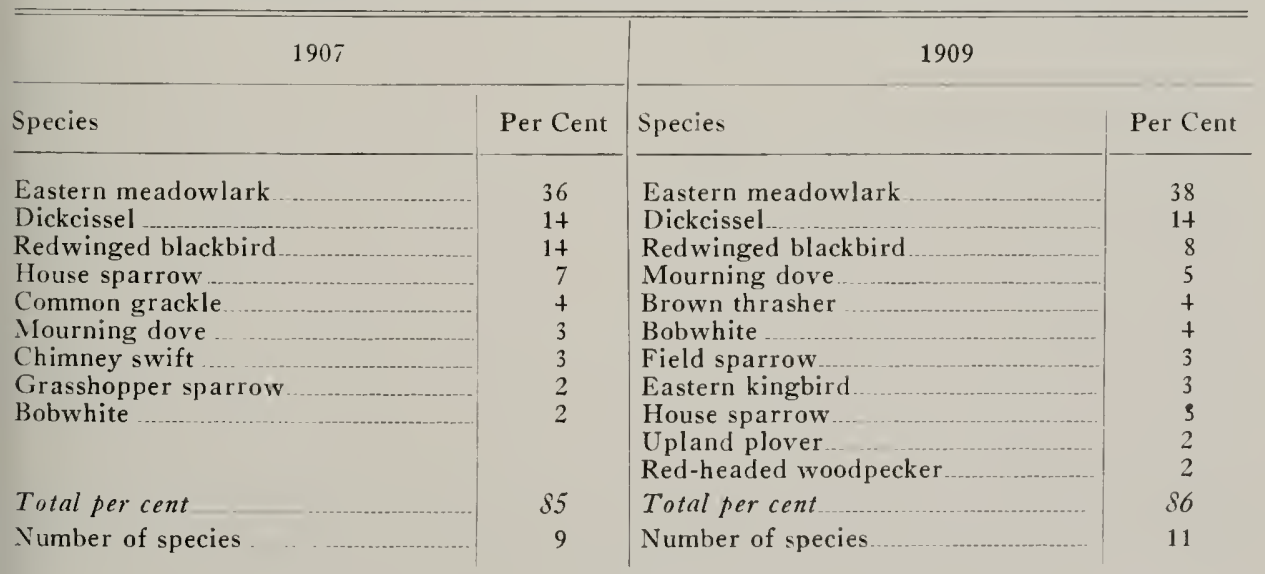


acre, table 23. Most of the large samples indicated densities of 2-3 birds per acre. Highest densities occurred in central Illinois. "The data suggest an increase in the birl population of this habitat after 1909 .

At least to species of birds were identified in red clover in summer, table 24 . As indicated, the eastern meadowlark, dick- "alfalfa, bromegrass, Ladino clover, and mixtures of these and other hay crops" (Ross \& Case 1956:72). We estimated that sweet clover fields occupied about $11+, 000$ acres of land in Illinois in 1957.

Sweet clover forms a dense cover 3-5 feet or more in height. Only 57 acres of sweet clover were censused for birds, table

Table 23.-Statistical data on summer bird populations in Illinois red clover fields as determined by strip censuses in the three zones. Data are (1) from all red clover fields censused and (2) from sample areas (each 4 acres or more) in these fields. The data from sample areas are for breeding species only.

\begin{tabular}{|c|c|c|c|c|c|c|c|c|c|}
\hline \multirow{3}{*}{$\begin{array}{c}\text { ZONE } \\
\text { AND } \\
\text { YEAR }\end{array}$} & \multicolumn{3}{|c|}{ All Red Clover Fields } & \multicolumn{6}{|c|}{ SAMPLE AREAS } \\
\hline & \multirow[b]{2}{*}{ Acres } & \multicolumn{2}{|c|}{ Birds Per Acre } & \multirow[b]{2}{*}{$\begin{array}{l}\text { Num- } \\
\text { ber }\end{array}$} & \multicolumn{5}{|c|}{ Birds Per Acre (Breeding Species Only) } \\
\hline & & $\begin{array}{c}\text { All } \\
\text { Species }\end{array}$ & $\begin{array}{c}\text { Breeding } \\
\text { Species } \\
\text { Only }\end{array}$ & & Range & Mean & $\begin{array}{l}\text { Standard } \\
\text { Deviation }\end{array}$ & $\begin{array}{c}\text { Standard } \\
\text { Error }\end{array}$ & $\begin{array}{c}\text { Mean } \pm \\
2 \text { S.E. }\end{array}$ \\
\hline \multicolumn{10}{|l|}{ Northern } \\
\hline 1957 & 58 & 2.9 & 2.0 & 6 & $0.7-4.4$ & 2.5 & $-\ldots$ & -.... & $\ldots$ \\
\hline 1958 & 53 & 2.6 & 1.9 & 5 & $1.0-3.6$ & 2.5 & $-\ldots$ & & \\
\hline Both years.. & 111 & $\ldots$ & $\ldots$ & 11 & $0.7-4.4$ & 2.5 & 1.1 & 0.3 & $1.9-3.1$ \\
\hline \multicolumn{10}{|l|}{ Central } \\
\hline $1907 \ldots$ & 32 & 3.0 & 0.8 & 3 & $0.2-1.0$ & 0.8 & $\ldots$ & ... & -..- \\
\hline $1909 \ldots$ & 14 & 3.8 & 1.3 & 2 & -.-. & 1.5 & -..- & -..- & $\ldots$ \\
\hline 1957. & 23 & 4.3 & 2.0 & 2 & ...- & 1.6 & ...- & --- & -... \\
\hline 1958 & 67 & 5.5 & 2.0 & 6 & $0.4-3.8$ & 2.0 & 1.2 & 0.4 & $1.2-2.8$ \\
\hline \multicolumn{10}{|l|}{ Southern } \\
\hline 1907 & 93 & 1.9 & 1.5 & 9 & $0.5-2.3$ & 1.3 & 0.6 & 0.2 & $0.9-1.7$ \\
\hline $1909 \ldots$ & 6 & $\ldots$ & & $\ldots$ & -..- & $\ldots$ & .... & $\ldots$ & $\ldots$ \\
\hline 1957 & 66 & 2.6 & 1.7 & 7 & $0.0-2.4$ & 1.2 & 0.8 & 0.3 & $0.6-1.8$ \\
\hline 1958 & 19 & 4.3 & 3.0 & $\cdots$ & -... & -.-- & $\ldots$ & --- & ... \\
\hline
\end{tabular}

cissel, grackle, and grasshopper sparrow were found with high frequency in this habitat. At least 11 species, the redwinged blackbird, dickcissel, eastern and western meadowlarks, bobolink, grasshopper sparrow, savannah sparrow, cowbird, prairie chicken, bobwhite, and pheasant, were breeding birds in red clover.

In this summer habitat, the redwinged blackbird populations increased dramatically in the period between the two surveys in central and southern Illinois, tables $2 t$ and 25 . There were indications of increasing populations of dickcissel, savannah sparrow, and meadowlarks in the northern zone. The grasshopper sparrow population may have declined in the northern zone.

Sweet Clover.-Sweet clover became popular as an Illinois hay crop after 1925 , but the acreage of this plant has decreased in recent years. It has been replaced by
3. Though the sample was small, it showed that the avifauna of sweet clover fields was obviously similar to that found in other hay crops with high population densities and relatively large numbers of species. Population densities for all species in sweet clover in the summers and zones for which data are available varied from 2.7 to 5.4 birds per acre $(274$ birds per 100 acres in northern Illinois and 539 in central Illinois, table 26). Principal breeding species in the habitat were the redwinged blackbird, meadowlarks, bobolink (northern zone), and dickcissel (central zone), table 26.

Vegetation of the sweet clover, taller than that of red clover, may be especially favorable to the redwinged blackbird, since this species appears to have attained considerably higher population densities in sweet clover. Population levels of the dickcissel were not so high in sweet clover 
Table 24.--Summer avifauna in Illinois red clover fields (birds per 100 acres) as determined by strip censuses in the three zones. Figures in parentheses indicate numbers of acres censused; * indicates breeding species in this habitat.

\begin{tabular}{|c|c|c|c|c|c|c|c|c|c|c|}
\hline \multirow[b]{2}{*}{ SPECIES } & \multicolumn{3}{|c|}{ Northern Zone } & \multicolumn{4}{|c|}{ Central ZONe } & \multicolumn{3}{|c|}{ SOUTHERN ZONE } \\
\hline & $\begin{array}{l}1909 \\
(11)\end{array}$ & $\begin{array}{l}1957 \\
(58)\end{array}$ & $\begin{array}{l}1958 \\
(53)\end{array}$ & $\begin{array}{l}1907 \\
(32)\end{array}$ & $\begin{array}{l}1909 \\
(14)\end{array}$ & $\begin{array}{l}1957 \\
(23)\end{array}$ & $\begin{array}{l}1958 \\
(67)\end{array}$ & $\begin{array}{l}1907 \\
(93)\end{array}$ & $\begin{array}{l}1957 \\
(66)\end{array}$ & $\begin{array}{l}1958 \\
(19)\end{array}$ \\
\hline & 108 & 88 & 83 & & & tt & 75 & 15 & 81 & 231 \\
\hline $\begin{array}{l}\text { *Dickcissel } \\
\text { Common grackle }\end{array}$ & 99 & $2+$ & $\begin{array}{r}15 \\
6\end{array}$ & +9 & 70 & 105 & 69 & 76 & 30 & +7 \\
\hline $\begin{array}{l}\text { Common grackle } \\
\text { * Meadowlark (species?) }\end{array}$ & 9 & 19 & 6 & 108 & 70 & 13 & +5 & 3 & $1+$ & 10 \\
\hline House sparrow & ...- & $\begin{array}{r}19 \\
7\end{array}$ & $\begin{array}{l}+0 \\
15\end{array}$ & $\begin{array}{r}6 \\
28\end{array}$ & +2 & $\begin{array}{r}30 \\
158\end{array}$ & 54 & +0 & 59 & 16 \\
\hline Horned lark & .... & & $\begin{array}{r}15 \\
9\end{array}$ & 28 & 14 & $\begin{array}{r}158 \\
35\end{array}$ & $\begin{array}{r}15 \\
118\end{array}$ & $\begin{array}{l}9 \\
1\end{array}$ & -..- & 10 \\
\hline Starling & & 20 & & & & 35 & 131 & 1 & $\cdots$ & $\ldots$ \\
\hline Upland plover & 108 & 7 & & & 7 & 9 & 13 & & 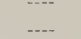 & -... \\
\hline${ }^{*}$ Grasshopper sparrow & 27 & 5 & + & 18 & 21 & 22 & + & 11 & 3 & (n... \\
\hline Mourning dove & -.. & 2 & 6 & 18 & $\ldots$ & 9 & 12 & 9 & +6 & -... \\
\hline *Bobolink & 18 & 50 & 25 & & & --- & - & & $-\cdots$ & $\cdots$ \\
\hline Yellow-shafted flicker & +5 & & 2 & 6 & 21 & $-\cdots$ & + & 1 & & \\
\hline $\begin{array}{l}\text { Barn swallow } \\
\text { Brown thrasher }\end{array}$ & 9 & 2 & $\cdots$ & 9 & $\begin{array}{l}1+ \\
+2\end{array}$ & $\cdots$ & + & 3 & 5 & 26 \\
\hline *Brown-headed cowbird & 27 & 5 & + & 3 & $\ldots$ & $\cdots$ & .... & $\ldots$ & 1 & $\ldots$ \\
\hline Vesper sparrow & 9 & $2+$ & + & & & $\ldots$. & & & 1 & $\ldots$. \\
\hline Red-headed woodpecker & 9 & 2 & & 3 & 21 & ..... & 1 & 1 & & -.. \\
\hline Robin & -..- & 2 & 2 & 15 & 14 & $\ldots$ & 1 & -.-- & 1 & \\
\hline American goldfinch & -...- & - & 2 & $\ldots$ & $-\ldots$ & $\cdots$ & 1 & $-\ldots$ & & 31 \\
\hline Chimney swift & -.- & & -.- & ...- & --- & + & 3 & -.-. & 1 & 21 \\
\hline *Savannah sparrow & & 7 & 21 & $\cdots$ & $\ldots$ & $-\cdots$ & $\ldots$ & & & $\ldots$ \\
\hline Eastern kingbird & 9 & -.-- & + & 6 & .... & -..- & $\ldots$ & 2 & 5 & \\
\hline Yellowthroat & .... & --.- & -.-- & … & $\ldots$ & $\cdots-\cdot$ & --- & & ...- & 26 \\
\hline Loggerhead shrike. & -... & $\ldots$ & -...- & .... & 21 & .... & -... & 1 & & $\ldots$ \\
\hline Field sparrow & ..... & 3 & .... & . & $1+$ & --.- & -..- & 1 & 3 & -... \\
\hline *Bobwhite & ....- & .... & ....- & & & 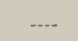 & -.-. & 9 & 1 & 10 \\
\hline *Greater prairie chicken & $\cdots$ & ? & $\cdots$ & & 14 & -.-. & $\cdots$ & $-\cdots$ & --- & -..- \\
\hline $\begin{array}{l}\text { Killdeer } \\
\text { * Ring }\end{array}$ & $\cdots$ & 2 & 6 & 3 & $\cdots$ & 4 & 3 & -- & $\cdots$ & --- \\
\hline $\begin{array}{l}{ }^{*} \text { Ring-necked pheasant } \\
\text { Common crow }\end{array}$ & 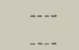 & 7 & $\cdots$ & 12 & -... & + & 1 & --- & -..- & $\cdots$ \\
\hline $\begin{array}{l}\text { Common crow } \\
\text { Eastern bluebird }\end{array}$ & 9 & $\ldots$ & $\ldots$ & & ...- & $\ldots . .$. & $\ldots$ & $\ldots$ & 1 & \\
\hline $\begin{array}{l}\text { Eastern bluebird } \\
\text { Orchard oriole }\end{array}$ & ....- & $\cdots$ & .... & 3 & $\ldots$. & .... & .... & -... & 5 & 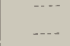 \\
\hline $\begin{array}{l}\text { Ruby-throated humming- } \\
\text { bird. }\end{array}$ & & & & & & & & & & \\
\hline & & 5 & $\cdots$ & 3 & -... & $\cdots$ & 1 & 1 & 3 & -..- \\
\hline $\begin{array}{l}\text { Song sparrow } \\
\text { Rough-winged swallow }\end{array}$ & $\ldots$. & & .... & -... & .... & -... & + & $\cdots$ & $\cdots$ & .... \\
\hline $\begin{array}{l}\text { Rough-winged swallow } \\
\text { Gray partridge }\end{array}$ & ..... & 3 & ..... & $\ldots$ & $\ldots$ & $\ldots$ & $\ldots$ & --- & $--\cdot$ & $\cdots$ \\
\hline $\begin{array}{l}\text { Gray partridge } \\
\text { Blue jay }\end{array}$ & .... & 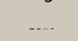 & $\ldots$ & $\ldots$ & ...- & & .... & 1 & $\cdots$. & $\cdots$ \\
\hline Baltimore oriole & .... & .... & .... & $\ldots$ & ---- & .... & -... & .... & 1 & .... \\
\hline Summer tanager. & -..- & -... & $\ldots$. & ...- &.--- & ...- & -..- & $\ldots$ & 1 & -... \\
\hline Indigo bunting & & & $\cdots$ & $\cdots-$ & -.-. & & $-\cdots-$ & -..- & 1 & \\
\hline Unidentified bird & 9 & 9 & 8 & 12 & & & 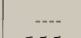 & 3 & .... & $\ldots$ \\
\hline Total birds per 100 acres & 795 & 293 & 256 & 302 & 385 & +33 & 555 & 187 & 263 & +28 \\
\hline Number of species & 13 & 20 & 17 & 16 & $1+$ & 11 & 19 & 17 & 20 & 10 \\
\hline
\end{tabular}

as in red clover; meadowlark populations were about the same in these two clovers.

\section{Alfalfa Fields (Summer)}

From about 18,000 acres in 1909 , the area of Illinois land planted to alfalfa had increased to approximately $1,400,000$ acres by 1957.
Alfalfa forms a cover 1-2 feet high, similar to that of red clover, though not quite so dense. The first cutting in Illinois is about half completed by mid-June and completed by early July. Second and third cuttings may be made in August and September. Most of the alfalfa fields we censused had mature stands. 
Table 25.-Common birds (species making up approximately 85 per cent of birds counted) in red clover fields in the southern zone of Illinois, summers, 1907 and 1957.

\section{7}

\begin{tabular}{l|c}
\hline \multicolumn{1}{c|}{ Species } & Per Cent \\
\cline { 2 - 2 } Dickcissel & +1 \\
Meadowlark (species?) & 23 \\
Redwinged blackbird & 8 \\
Grasshopper sparrow & 6 \\
Mourning dove & 5 \\
House sparrow & 5 \\
Bobwhite & 5 \\
Total per cent & $93^{*}$ \\
Number of species & $7^{*}$
\end{tabular}

1957

\begin{tabular}{l|c}
\hline \multicolumn{1}{c|}{ Species } & Per Cent \\
\hline Redwinged blackbird & 30 \\
Meadowlark (species?) & 22 \\
Mourning dove & 17 \\
Dickcissel & 11 \\
Common grackle & 5 \\
& \\
Total per cent & 85 \\
Number of species & 5
\end{tabular}

* Five species made up 83 per cent of the birds counted. Seven species are included in this table because the last three had the same percentage.

All but 9 of the 237 acres of alfalfa censused were covered in 1957-1958; the largest samples represented northern Illinois.

Bird population densities in summer alfalfa fields varied from 2.1 to +.2 birds per acre, large samples in northern Illinois indicating densities of 2.1-2.2 birds per acre, table 27 . These populations were notably lower than those for other hay crops (mixed hay and the clovers), figs. 22-24. 'The difference may be attributed largely to the redwinged blackbird population, which attained notably higher densities in clover than in alfalfa fields. At least 30 species of birds were identified in alfalfa, table 28 . In this habitat, the redwinged blackbird, eastern meadowlark, and dickcissel occurred in all zones in both 1957 and 1958. The breeding avifauna was almost the same as that recorded in red clover fields. Lists of common species
Table 26. - Summer avifauna in Illinois sweet clover fields (birds per 100 acres) as determined by strip censuses in two zones. Figures in parentheses indicate numbers of acres censused; * indicates breeding species in this habitat.

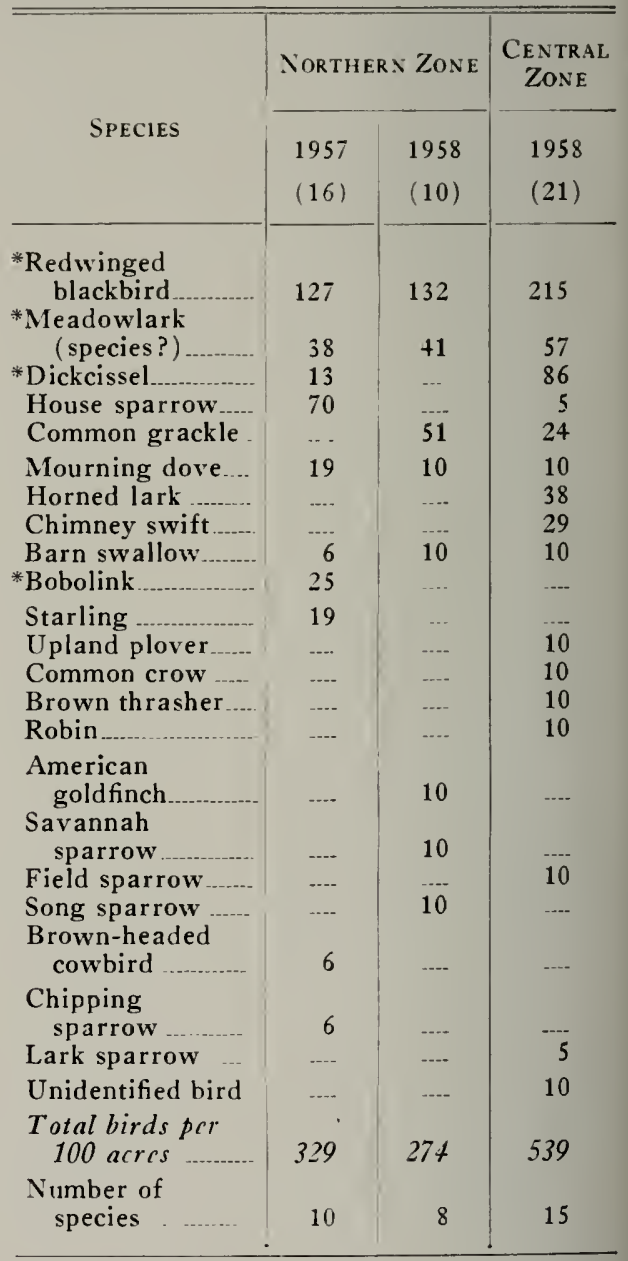

of birds in alfalfa and other types of hay in the northern zone are shown in table 29.

\section{Marshland (Summer)}

The amount of prairie marshland in the state of Illinois has been reduced since 1909 as the demand for tillable and urban land has increased. From data presented in a report of a U. S. Fish and Wildlife Service wetlands survey (Shaw \& Fredine $1956: 7,20-5)$, we calculated that there were about 558,000 acres of prairie type marsh in Illinois in 1906 and only about 60,000 in 1950. 
Table 27.-Statistical data on summer bird populations in Illinois alfalfa fields as determined by strip censuses in the three zones. Data are (1) from all alfalfa fields censused and (2) from sample areas (each 4 acres or more) in these fields.

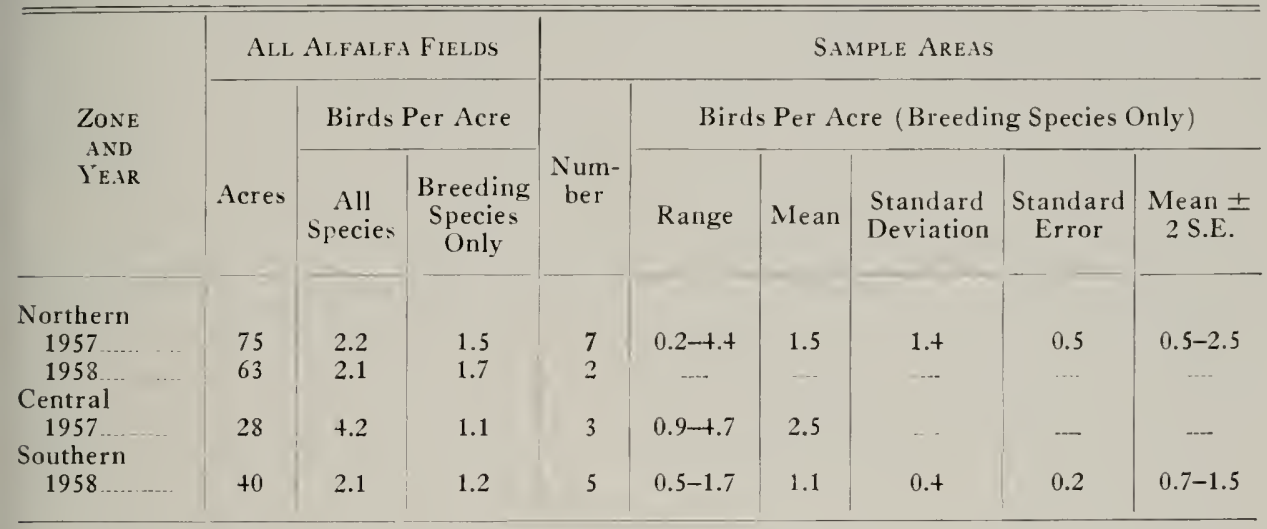

Table 28.-Summer avifauna in Illinois alfalfa fields (birds per 100 acres) as determined by strip censuses in the three zones. Figures in parentheses indicate numbers of acres censused; * indicates breeding species in this habitat.

*Redwinged blackbird

*Meadowlark (species?)

Horned lark.

*Dickcissel

Starling

House sparrow

* Grasshopper sparrow

*Bobolink

Barn swallow

Indigo bunting

Mourning dove

*Ring-necked pheasant

Upland plover

Vesper sparrow

Killdeer

Yellowthroat

* Brown-he aded cowbird

Cardinal

* Savannah sparrow

Common grackle

*Bobwhite

Eastern kingbird

Brown thrasher.

Robin.

Chimney swift

Common crow

Swamp sparrow

Yellow-shafted flicker

American goldfinch.

Field sparrow

Unidentified bird

Total birds per 100 acres

Number of species
Northern Zone Central Zone Southern Zone

SPECIES

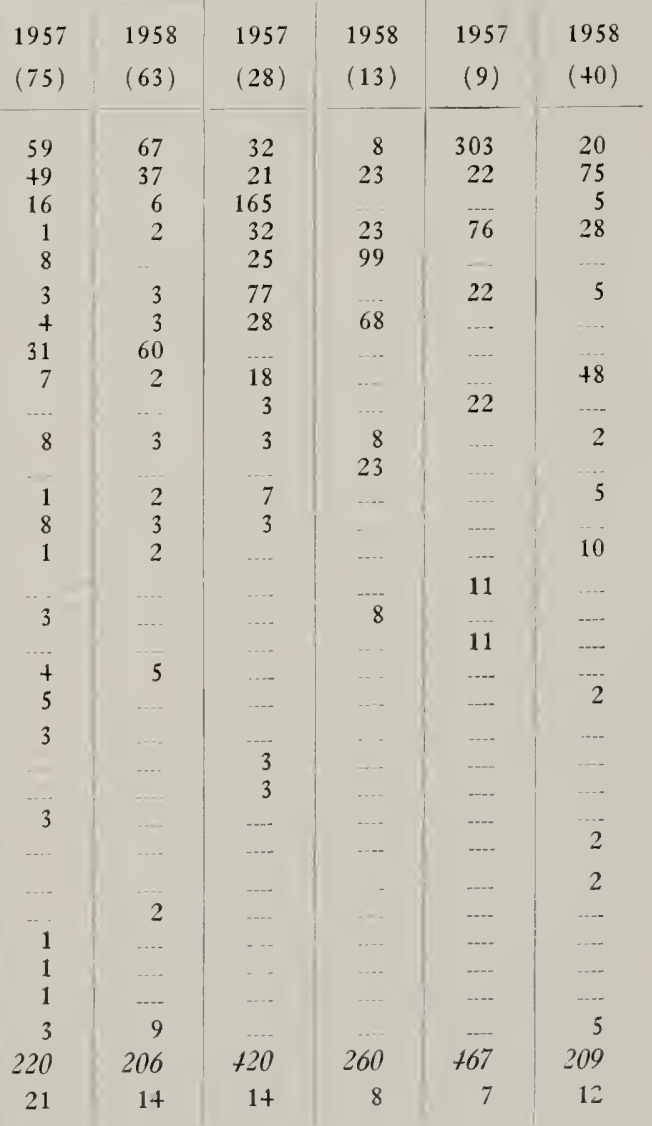


Table 29.-Common birds (species making up approximately 85 per cent of birds counted in strip censuses) in different types of hay crops in the northern zone of Illinois, summers, 1957 and 1958 (combined data).

\begin{tabular}{|c|c|c|c|c|c|}
\hline \multicolumn{2}{|l|}{ Mixed HaY } & \multicolumn{2}{|l|}{ Red Clover } & \multicolumn{2}{|l|}{ Alfalfa } \\
\hline Species & $\begin{array}{c}\text { Per } \\
\text { Cent }\end{array}$ & Species & $\begin{array}{l}\text { Per } \\
\text { Cent }\end{array}$ & Species & $\begin{array}{l}\text { Per } \\
\text { Cent }\end{array}$ \\
\hline Redwinged blackbird. & & Redwinged blackbird & & Redwinged blackbird. & 30 \\
\hline Bobolink & $1+$ & Bobolink & 15 & Bobolink & 22 \\
\hline Meadowlark (species?) & 8 & Meadowlark (species?) & 11 & Meadowlark (species?) & 21 \\
\hline Cominon grackle & 8 & Dickcissel & 8 & Horned lark & 5 \\
\hline Savannah sparrow & 5 & Vesper sparrow & 6 & Mourning dove. & 3 \\
\hline Brown-headed cowbird. & 2 & Savannah sparrow. & 5 & Vesper sparrow & 3 \\
\hline Mourning dove & 2 & $\begin{array}{l}\text { House sparrow } \\
\text { Starling }\end{array}$ & $\begin{array}{l}4 \\
4\end{array}$ & & \\
\hline Total per cent & 85 & Total per cent & 86 & Total per cent & 84 \\
\hline Number of species & 7 & Number of species ... & 8 & Number of species.... & 6 \\
\hline
\end{tabular}

The marshes censused for our report were low wetlands in pastures of northeastern Illinois. Vegetation consisted of sedges and cattails at the margins of open water. Only small areas of this habitat were censused; the total area censused was 155 acres, most of it in the summers of 1957 and 1958 , table 3.

The associated avifauna, as well as the marshland habitat, was distinctive: a very high bird population and a variety of species. In northern Illinois, the density of the bird population in marsh exceeded that in any other habitat but urban residential area. Marshland population densities varied from 4.9 to 7.4 birds per acre ( +88 birds per 100 acres in 1957 and 742 birds per 100 acres in 1909, table 30).

Despite the small acreage covered, at least +1 species of birds were identified in marshes, table 30. At least 18 of these nested in the habitat; three additional species, the bobolink and the two meadowlarks, probably nested at the dry margins of marshland.

Judged from the avifauna, the summer marsh habitat covered in 1909 was not strictly comparable to that censused in 1957-1958, though the commonest species for both periods were the redwinged blackbird and the grackle, table 30 .

\section{Shrub-Grown Areas (Summer)}

Throughout Illinois, but especially in southern Illinois, there are small scattered tracts of shrub-grown grassland or "wasteland." The dominant features of the habi- tat are deciduous shrubs under 10 feet in height and intermittent open areas of grass and weeds. In both surveys, this habitat was often found at the margins of woods. It was similar in some respects to fallow fields and pastures but differed from them in having a large amount of shrub cover. The acreage of this habitat was small compared to that of open-field areas and forest; only 267 acres of shrubgrown areas were censused, principally in 1957-1958 in southern Illinois. We estimated that there were about 500,000 acres of nonurban shrub-grown habitat in Illinois in 1907-1909 and in 1957-1958.

In terms of both numbers of birds and numbers of species, this was probably the richest summer habitat in the state, table 31.

Summer population densities for large samples (30 acres or more) of nonurban shrub-grown areas varied from 2.3 to +.4 birds per acre (average: 3.4 ). We have insufficient data to determine whether there was a change in population density for this habitat in the half century following 1909.

At least 74 species of birds were identified in shrub-grown areas in summer, table 31 ; only 2, field sparrow and goldfinch, were found in all census years in all zones. Other species that occurred with high frequency were the indigo bunting, mourning dove, cowbird, cardinal, yellowbreasted chat, redwinged blackbird, grackle, towhee, brown thrasher, and catbird, tables 31-33. 
In this habitat, the population density varied considerably from 1957 to 1958 , table 31 . That there was qualitative variation from zone to zone is shown in the lists of common birds, tables 32 and 33. In 1957-1958, the redwinged blackbird was the most numerous species in the northern zone, the field sparrow in the central zone, and the indigo bunting in the southern zone.

Edge shrub habitat, such as fencerow and roadside, had very high bird populations. The 45 acres of this habitat censused in the state (all in 1957-1958) had a mean density of 22.3 birds per acre; 21.1 in the northern zone, 19.1 in the central,

Table 30.-Summer avifauna in northern Illinois marshland (birds per 100 acres) as determined by strip censuses. Figures in parentheses indicate numbers of acres censused; * indicates breeding species in this habitat. The acreage of marshland censused in the central and southern zones was too small to be included here.

\begin{tabular}{|c|c|c|c|}
\hline SPECIES & $\begin{array}{l}1909 \\
(19)\end{array}$ & $\begin{array}{l}1957 \\
(29)\end{array}$ & $\begin{array}{l}1958 \\
(58)\end{array}$ \\
\hline *Redwinged blackbird & \multirow{10}{*}{$\begin{array}{r}494 \\
130 \\
88 \\
- \\
- \\
- \\
-5 \\
5\end{array}$} & \multirow{5}{*}{$\begin{array}{r}162 \\
93 \\
3 \\
34 \\
58\end{array}$} & \multirow{2}{*}{$\begin{array}{l}226 \\
117\end{array}$} \\
\hline *Common grackle & & & \\
\hline Bobolink & & & \\
\hline *Black tern & & & 55 \\
\hline * Swamp sparrow & & & 14 \\
\hline *Yellow-headed blackbird & & 7 & $\begin{array}{l}65 \\
55\end{array}$ \\
\hline *Long-billed marsh wren & & 14 & 24 \\
\hline Song sparrow & & 10 & 10 \\
\hline Starling & & 21 & 2 \\
\hline Robin & & $\ldots$ & 15 \\
\hline *Blue-winged teal & & .... & 19 \\
\hline Meadowlark (species?) & 10 & $-\ldots$ & 9 \\
\hline *Killdeer & $\ldots$ & & 17 \\
\hline *Spotted sandpiper & $\ldots$ & 7 & 10 \\
\hline Ring-necked pheasant & & 14 & -..- \\
\hline Savannah sparrow & 5 & 7 & $\ldots$ \\
\hline *American bittern & --- & 10 & $\ldots$. \\
\hline *Least bittern & $\ldots$ & & 10 \\
\hline American goldfinch & $\ldots$ & 10 & $\ldots$ \\
\hline Brown thrasher & -..- & 7 & 2 \\
\hline *Brown-headed cowbird & $\ldots$ & 7 & 2 \\
\hline *American coot & $\ldots$ & & 7 \\
\hline *Yellowthroat & $\ldots$ & 3 & 3 \\
\hline Green heron & 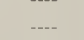 & 3 & 2 \\
\hline *Mallard & & $\ldots .$. & 5 \\
\hline Yellow-billed cuckoo & 5 & & 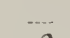 \\
\hline Short-billed marsh wren & $\ldots$. & 3 & 2 \\
\hline Horned grebe & $\ldots$ & $\ldots$ & 3 \\
\hline Great blue heron & $\ldots$ & $\cdots$ & 3 \\
\hline *Common snipe & & 3 & $\ldots$ \\
\hline Traill's fycatcher & .... & 3 & .... \\
\hline Rough-winged swallow & $\ldots$ & 3 & $\ldots$ \\
\hline Common crow & $\ldots$ & $\ldots$ & 3 \\
\hline Eastern bluebird & $\ldots$ & 3 & -... \\
\hline Catbird & $\ldots$ & 3 & $\ldots$. \\
\hline Black-crowned night heron & $\ldots$ & $\ldots$. & 2 \\
\hline *King rail & ...- & ... & 2 \\
\hline *Virginia rail & $\ldots$ & .... & 2 \\
\hline Belted kingfisher & $\ldots$ & $-\cdots$ & 2 \\
\hline Tree swallow & $\ldots$ & $\ldots$ & 2 \\
\hline Rail (species?) & $\ldots$. & $\ldots$ & 3 \\
\hline Unidentified bird & & -..- & 9 \\
\hline Total birds per 100 acres & $7+2$ & 488 & 702 \\
\hline Number of species & 8 & 24 & 30 \\
\hline
\end{tabular}


and 25.1 in the southern. This habitat was so limited in acreage (we estimated that there were about $\$ 6,000$ acres of edge shrubbery in the state, most of it in southern Illinois) that it accounted for only a small part of the state population of birds.

Table 31.-Summer avifauna in Illinois shrub-grown areas as determined by strip censuses in the three zones (no edge shrub included in this table). Figures in parentheses indicate num. bers of acres censused. Most of the species listed are known to nest in this habitat.

\begin{tabular}{|c|c|c|c|c|c|c|c|c|}
\hline \multirow{2}{*}{ SPECIES } & \multicolumn{2}{|c|}{$\begin{array}{c}\text { NORTHERN } \\
\text { ZONE }\end{array}$} & \multicolumn{2}{|c|}{$\begin{array}{c}\text { Central } \\
\text { ZONE }\end{array}$} & \multicolumn{4}{|c|}{$\begin{array}{l}\text { SOUTHERN } \\
\text { ZONE }\end{array}$} \\
\hline & $\begin{array}{l}1957 \\
(15)\end{array}$ & $\begin{array}{l}1958 \\
(17)\end{array}$ & $\begin{array}{r}1957 \\
(15)\end{array}$ & $\begin{array}{l}1958 \\
(35)\end{array}$ & $\begin{array}{l}1907 \\
(17)\end{array}$ & $\begin{array}{l}1909 \\
(39)\end{array}$ & $\begin{array}{l}1957 \\
(67)\end{array}$ & $\begin{array}{l}1958 \\
(62)\end{array}$ \\
\hline $\begin{array}{l}\text { Field sparrow } \\
\text { Indigo bunting }\end{array}$ & 88 & 35 & 107 & 111 & 74 & 26 & 49 & 24 \\
\hline $\begin{array}{l}\text { Indigo bunting } \\
\text { Redwinged blackbird }\end{array}$ & $\begin{array}{r}7 \\
167\end{array}$ & 52 & 13 & 23 & $\begin{array}{l}28 \\
17\end{array}$ & $\begin{array}{r}41 \\
2\end{array}$ & $\begin{array}{l}46 \\
15\end{array}$ & $\begin{array}{r}42 \\
6\end{array}$ \\
\hline American goldfinch & 47 & 46 & 53 & 23 & 23 & 28 & 1 & 10 \\
\hline Brown-headed cowbird & 27 & 35 & 7 & 23 & -.- & 23 & 16 & 19 \\
\hline Cardinal & 7 & & & 11 & 28 & 33 & 15 & 19 \\
\hline Brown thrasher & 41 & 17 & 7 & 17 & & 5 & 4 & \\
\hline Yellow-breasted chat & & & 13 & 11 & 6 & 33 & 27 & 8 \\
\hline Catbird & 41 & 23 & 7 & 17 & .... & 2 & 1 & ...- \\
\hline Song sparrow & 41 & 35 & ..... & 11 & -..- & $\ldots$ & & ...- \\
\hline Mourning dove & 7 & 6 & 7 & 14 & & 28 & 10 & 11 \\
\hline Yellowthroat & 20 & & .... & & 6 & 36 & 15 & 6 \\
\hline Common grackle & 47 & 12 & $\ldots$ & 6 & 6 & -..- & 1 & 3 \\
\hline Savannah sparrow & 60 & & .... & & & & & \\
\hline Rufous-sided towhee & $\ldots$ & 6 & -... & 6 & 11 & 8 & 16 & 8 \\
\hline Red-headed woodpecker & $\ldots$ & $\ldots$ & 7 & 3 & & 36 & & \\
\hline Blue jay & ...- & ...-. & $\ldots$ & 9 & 17 & 13 & 4 & 1 \\
\hline Bank swallow & & $\ldots$ & ..... & 43 & .... & $\ldots$ & & $\ldots$ \\
\hline Chickadee (species?) & 7 & 6 & .... & 11 & ..-.- & ...- & 16 & .... \\
\hline Meadowlark (species?) & 14 & 23 & -.-- & $\ldots$ & --- & 2 & $\ldots$. & .... \\
\hline Eastern kingbird & 20 & ..-.- & ...- & 11 & -... & & 1 & -..- \\
\hline Tufted titmou & & ..-. & ...- & 6 & .... & 8 & 18 & ...- \\
\hline Dickcissel & 20 & ..-- & 7 & .... & & 5 & ... & $\ldots$ \\
\hline Yellow-billed cuckoo & 7 & ....- & ... & $\ldots$ & 11 & 10 & 1 & 1 \\
\hline Orchard oriole & $-\ldots$ & $-\ldots$ & $\ldots$ & 3 & $-\cdots-$ & 13 & 6 & 8 \\
\hline Bobwhite & -... & $\ldots .-$ & 7 & $\ldots$ & 11 & 5 & 3 & 1 \\
\hline Carolina wren & & & & $\ldots$ & 6 & 10 & 7 & 3 \\
\hline Vesper sparrow & 20 & 6 & .... & ...- & ... & ....- & 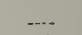 & ....- \\
\hline Robin & & 6 & .... & 3 & 11 & ....- & 3 & $\ldots$ \\
\hline House wren & 14 & .... & ...- & 6 & & .... & 1 & .... \\
\hline Traill's flycatcher & 7 & 6 & 7 & $\ldots$ & -.. & & $\ldots$ & \\
\hline Eastern phoeb & 7 & ...- & $\ldots$ & ...- & .... & 8 & .--- & 3 \\
\hline Wood thrush & .... & ...- & $\ldots$ & .... & & 8 & 3 & 6 \\
\hline Great crested flycatcher & $\ldots$ & ..... & .... & ..... & 11 & 2 & 3 & \\
\hline Eastern wood pewee.-. & $-{ }_{--}$ & .... & $\ldots$ & 6 & $\ldots$ & 2 & 1 & 5 \\
\hline Gray partridge... & 14 & ...- & .... & ....- & ...- & ...-- & ...- & ...- \\
\hline Baltimore oriole & 14 & .... & ....- & $\ldots$ & ..... & -..- & -.-- & ..... \\
\hline Starling & 7 & ...- & -..- & 6 & $-\ldots$ & $-\cdots$ & $\ldots$ & \\
\hline White-eyed vireo & .... & ....- & ...- & & 6 & 2 & 4 & 1 \\
\hline American redstart & .... & ...- & ....- & 11 & $\ldots$ & $\ldots$ & -..- & \\
\hline Bell's vireo & $\ldots$ & .... & $\ldots$. & 3 & $\ldots$ & -..- & 4 & 3 \\
\hline Prairie warbler & & & .... & & $\ldots$ & $\ldots$ & 7 & 3 \\
\hline Ruby-throated hummingbird & ...- & ...-. & ..-- & 3 & .... & 5 & & 1 \\
\hline Downy woodpecker & .... & $\ldots$ & ...-. & & ...- & 5 & 3 & 1 \\
\hline House sparrow & $\ldots$ & $\ldots$ & -.-- & 3 & ...- & -..- & .... & 6 \\
\hline Red-bellied woodpecker... & $\ldots$ & $\ldots$ & $\ldots$ & $\ldots$ & $\ldots$ & 5 & $\ldots$ & 3 \\
\hline Common crow & $\ldots$ & .... & .... & $\ldots$ & .... & 8 & ...- & \\
\hline Bewick's wren & -... & .... & --- & ...- & 6 & 2 & $\ldots . .$. & ....- \\
\hline Red-tailed hawk & $\ldots$ & ...- & 7 & $\ldots$ & & $\ldots$ & $\ldots$ & ....- \\
\hline Ring-necked pheasant & 7 & - & -.-- & ...- & ....- & .... & .... & $\ldots$ \\
\hline
\end{tabular}


Table 33.-Common birds (species making up approximately 85 per cent of birds counted in strip censuses) in slirub-grown areas in the northern and central zones of Illinois, summers. $1957-1958$.

\begin{tabular}{|c|c|c|c|}
\hline \multicolumn{2}{|l|}{ NORTHERN ZONE } & \multicolumn{2}{|l|}{ Central Zone } \\
\hline Species & Per Cent & Species & Per Cent \\
\hline Redwinged blackbird & 20 & Field sparrow & 33 \\
\hline Field sparrow & 11 & American goldfinch & 11 \\
\hline American goldfinch & 8 & Bank swallow & 6 \\
\hline Song sparrow.......... & 7 & Indigo bunting & 5 \\
\hline Catbird & 6 & Brown-headed cowbird & 4 \\
\hline Brown-headed cowbird & 6 & Catbird & + \\
\hline Savannah sparrow & 5 & Brown thrasher & + \\
\hline Common grackle & 5 & Yellow-breasted chat & + \\
\hline Brown thrasher & 5 & Mourning dove & 3 \\
\hline Meadowlark (species?) & 3 & Eastern kingbird & 2 \\
\hline Vesper sparrow & 2 & Chickadee (species?) & 2 \\
\hline Eastern kingbird & 2 & American redstart & 2 \\
\hline Yellowthroat & 2 & Cardinal & 2 \\
\hline Dickcissel & 2 & Song sparrow & 2 \\
\hline Total per cent & 84 & Total per cent & St \\
\hline Number of species & 14 & Number of species & 14 \\
\hline
\end{tabular}

A related edge habitat, the hedgerows, also had very high populations; for the 13 acres of this habitat censused in the state, the mean density was 23.2 birds per acre. We estimated that there were about 13,000 acres of hedgerows in the state in 1958. Many acres of this valuable habitat for birds have been eliminated since then.

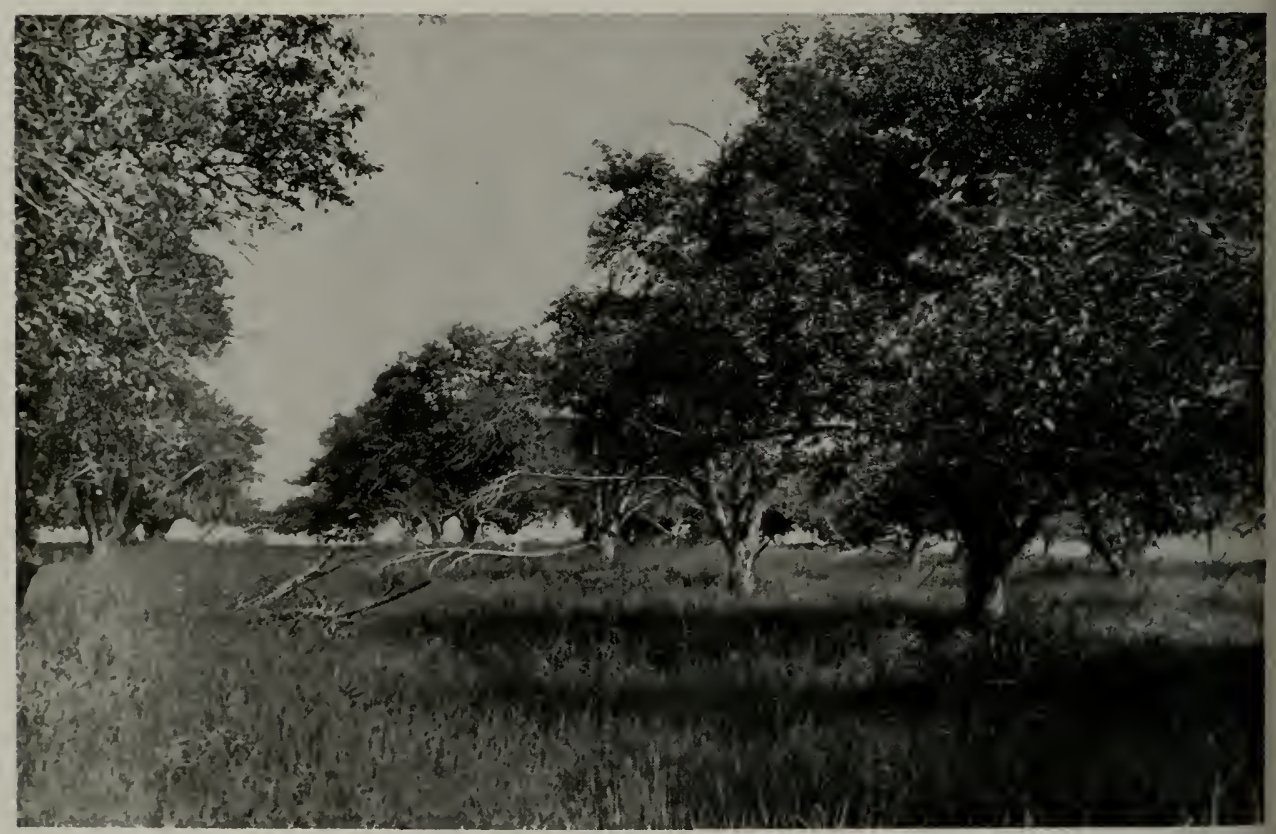

Fig. 20.-Orchard habitat in summer. The acreage of land in orchards declined greatly between 1909 and 1957. Because orchards comprise a habitat rich in both numbers and variety of birds, the acreage change represented a definite loss to the Illinois avifauna. The photograph was taken near Thompsonville, Franklin County, in southern Illinois, June 5, 1907, by Alfred O. Gross. 


\section{Orchards (Summer)}

The total acreage of orchards in Illinois was reduced from about 300,000 acres in 1909 to about 31,000 in 1957.
This very uniform habitat is closely allied to shrubby areas. The orchards censused were mature or nearly mature pure stands, most of them of either apple or

Table 34.-Summer avifauna in Illinois orchards (birds per 100 acres) as determined by strip censuses in two zones. Figures in parentheses indicate numbers of acres censused. Most of the species listed are known to nest in this habitat. The acreage of orchards censused in some zones and years was too small to be included here.

\begin{tabular}{|c|c|c|c|c|c|}
\hline \multirow[b]{2}{*}{ SPECIES } & \multirow{2}{*}{$\begin{array}{c}\text { NORTHERN ZONE } \\
1958 \\
(35)\end{array}$} & \multicolumn{4}{|c|}{ SOUTHERN ZONE } \\
\hline & & $\begin{array}{l}1907 \\
(19)\end{array}$ & $\begin{array}{l}1909 \\
(26)\end{array}$ & $\begin{array}{c}1957 \\
(8)\end{array}$ & $\begin{array}{l}1958 \\
(70)\end{array}$ \\
\hline House sparrow & $\ldots$ & 159 & 19 & 50 & 66 \\
\hline Mourning dove ..... & 3 & 74 & 30 & 87 & 39 \\
\hline Field sparrow & 17 & 53 & 64 & 62 & 19 \\
\hline Redwinged blackbird & $\ldots$ & 5 & $\ldots$ & 137 & 19 \\
\hline Common grackle & 3 & 63 & $\cdots$ & --- & 57 \\
\hline American goldfinch & 99 & $-\ldots$ & $\ldots$ & $\ldots$ & 9 \\
\hline Orchard oriole & $\ldots$ & 47 & 38 & 12 & $\ldots$ \\
\hline Robin & 6 & 32 & 26 & 25 & 3 \\
\hline Catbird & 6 & 16 & 35 & 25 & $\ldots$ \\
\hline Indigo bunting & 14 & 11 & 11 & 25 & 11 \\
\hline Cardinal & $\ldots$ & 11 & 15 & 12 & 21 \\
\hline Eastern meadowlark & $\cdots$ & 16 & 19 & 12 & 9 \\
\hline Starling & -..- & & $\ldots$ & 25 & 31 \\
\hline Dickcissel & $\ldots$ & 5 & -..- & 50 & 1 \\
\hline Blue jay & 3 & $\ldots$ & 42 & $\ldots$ & 6 \\
\hline Brown thrasher & - & 21 & 15 & $\ldots$ & 13 \\
\hline Mockingbird........ & $\ldots$ & 11 & 23 & 12 & 1 \\
\hline Bobwhite & ...- & & 15 & 25 & + \\
\hline Yellowthroat & $\ldots$ & 11 & + & 25 & 1 \\
\hline Bewick's wren & $\ldots$. & $\ldots$ & 26 & 12 & 1 \\
\hline Tufted titmouse & .... & 11 & 15 & & 1 \\
\hline Barn swallow & $\ldots$ & & $\ldots$ & 12 & 14 \\
\hline House wren & .... & 16 & 8 & --- & 1 \\
\hline Yellow-shafted flicker & 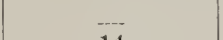 & 21 & + & $\ldots$ & $\cdots$ \\
\hline Chimney swift & 14 & 5 & -..- & $-\cdots$ & 1 \\
\hline Yellow-billed cuckoo & $\cdots$ & 5 & 8 & $\cdots$ & 6 \\
\hline Eastern kingbird & $\ldots$ & 11 & 4 &.-- & 4 \\
\hline Carolina chickadee & $\ldots$ & 11 & 4 & -..- & 1 \\
\hline Yellow warbler & $\cdots-$ & 16 & $\ldots$ & $\ldots$ & $\cdots$ \\
\hline Rufous-sided towhee. & $\cdots .$. & --- & 11 & $-\cdots-$ & 4 \\
\hline Chipping sparrow & $-\cdots$ & 11 & $\ldots$ & $\ldots$ & 3 \\
\hline Carolina wren & $\cdots$ & 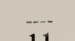 & 11 & $-\cdots$ & $\ldots$ \\
\hline Baltimore oriole & & 11 & $\ldots$ & $\ldots$ & $\cdots$ \\
\hline Song sparrow & 11 & --- & -- & --- & -..- \\
\hline Red-headed woodpecker & $\ldots$ & 5 & 4 & $\cdots$ & $\cdots$ \\
\hline Great crested flycatcher & $\cdots$ & 5 & + & -..- & $\cdots$ \\
\hline Loggerhead shrike & $\cdots$ & $\cdots$ & 8 & $\cdots$ & 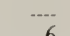 \\
\hline Common nighth awk & $\cdots$ &.-- & $\cdots \cdot$ & --- & 6 \\
\hline Eastern phoebe & $\cdots$ & $\cdots$ & $\cdots$ & .... & 6 \\
\hline Brown-headed cowbird & 3 & --- & $\ldots$ & $\cdots$ & \\
\hline Acadian flycatcher & $\cdots$ & 5 & 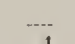 & $\cdots$ & $\cdots$ \\
\hline Common crow & $\ldots$ & $-\cdots$ & + & -..- & 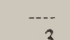 \\
\hline Yellow-breasted chat & & $---\cdot$ & .... & $\cdots$ & 3 \\
\hline Vesper sparrow & 3 & -.-. & $\ldots$ & $\cdots$ & $\overline{1}$ \\
\hline Grasshopper sparrow & $\ldots$ & $-\ldots$ & -.-- & $\ldots$ & 1 \\
\hline Unidentified bird & 17 & $\ldots$ & 8 & 50 & 26 \\
\hline Total birds per 100 acres & 199 & 668 & 475 & 658 & 391 \\
\hline Number of species & 12 & 28 & 27 & 17 & 32 \\
\hline
\end{tabular}


peach trees. Trees were 10-20 feet tall and equidistantly spaced in rows. The ground cover was bluegrass. A typical orchard censused in 1907 is shown in fig. 20. In the two study periods combined, 172 acres of orchard were censused, table 3 , most of them in southern Illinois.

Orchards were shown to be excellent bird habitat, supporting high populations and a varied avifauna. In southern Illinois, summer hird populations in orchards were higher than in any other habitat except red clover and residential areas, fig. 24. Census data for the years with the largest acreages censused, 1909 and 1958, indicated populations of 3.9 and 4.7 birds per acre in the southern zone and 2.0 birds per acre in the northern zone $(391,475$, and 199 birds per 100 acres, table 34$)$.

At least +5 species of birds were identified in orchards, table 34 , virtually all being potential nesters in this habitat. The mourning dove, field sparrow, robin, and indigo bunting were reported in both northern and southern Illinois in the summers for which census figures are available. In addition, in the southern zone, the house sparrow, cardinal, eastern meadowlark, mockingbird, and yellowthroat were listed in all census years.
Comparisons of bird populations of 1907-1909 with those of 1957-1958 are difficult to make because of the marked year-to-year variations and the small sizes of the samples, but there appears to he no real difference in total density of the orchard bird populations of the two periods. Population changes in some species occurred, however, tahle 35. An increase in population of the redwinged blackbird was apparent in this as in other habitats. and an increase in the barn swallow population in orchards was indicated. An observable decline occurred in orchard populations of a few species, particularly the orchard oriole, tufted titmouse, house wren, yellow-shafted flicker, Carolina chickadee, red-headed woodpecker, crested flycatcher, and eastern kingbird, tables $3+$ and 35.

\section{Forests (Summer)}

About +0 per cent of the land area of Illinois was originally forested, but threefourths of this area has been cleared (King \& Winters 1952:20-1). We estimated that there were about $3,500,000$ acres of forest in Illinois in 1907-1909 and nearly $4,000,000$ acres in 1957-1958. Most of the forest lies in southern Illinois.

Table 35.-Common birds (species making up approximately 85 per cent of birds counted in strip censuses) in orchards in the southern zone of Illinois, summers, 1907-1909 and 19571958; + indicates approximately 0.5 per cent.

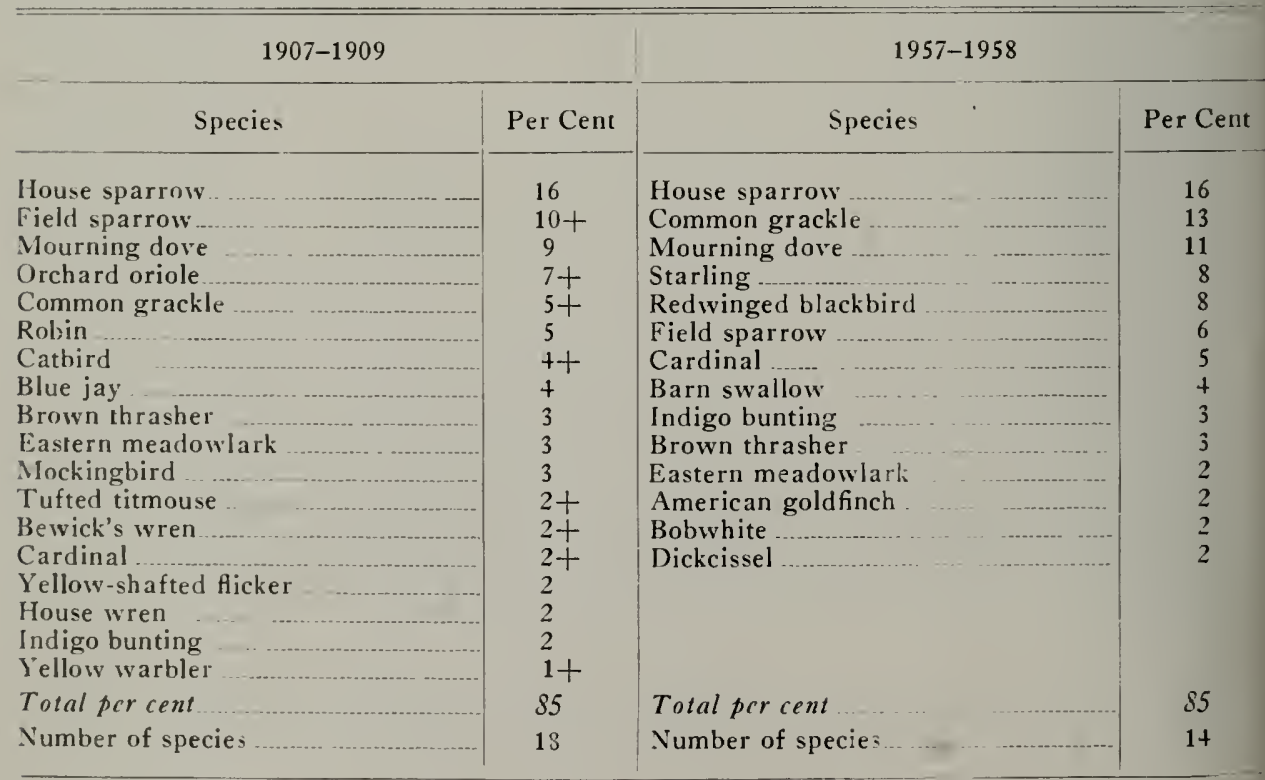


Table 38. - Summer avifauna in Illinois forests (birds per 100 acres) as determined by strip censuses in the three zones (forests with and forests without understory were included in the counts). Figures in parentheses indicate numbers of acres censused; data from the northern and central zones in 1907 and 1909 are too meager to be valid and they have not been included in this table. All stands included in this table were mature, natural deciduous forest typical of Illinois. Dense thickets of young saplings were not classified as forest. Most of the species of birds listed in this table are known to nest in forest.

\begin{tabular}{|c|c|c|c|c|c|c|c|c|}
\hline \multirow{2}{*}{ SPECIES } & \multicolumn{2}{|c|}{$\begin{array}{l}\text { NORTHERN } \\
\text { ZONE }\end{array}$} & \multicolumn{2}{|c|}{$\begin{array}{l}\text { CEnTRAL } \\
\text { ZONe }\end{array}$} & \multicolumn{4}{|c|}{ SOUTHERN ZONE } \\
\hline & $\begin{array}{l}1957 \\
(79)\end{array}$ & $\begin{array}{l}1958 \\
(98)\end{array}$ & $\begin{array}{l}1957 \\
(97)\end{array}$ & $\begin{array}{c}1958 \\
(117)\end{array}$ & $\begin{array}{l}1907 \\
(20)\end{array}$ & $\begin{array}{l}1909 \\
(40)\end{array}$ & $\begin{array}{c}1957 \\
(174)\end{array}$ & $\begin{array}{r}1958 \\
(166)\end{array}$ \\
\hline Cardinal & 14 & 6 & 33 & 29 & 10 & 20 & 16 & 28 \\
\hline Tufted titmouse & 1 & .... & 25 & 16 & 35 & 5 & 17 & 21 \\
\hline Indigo bunting & 5 & 4 & 7 & 9 & 35 & 25 & 21 & 10 \\
\hline Blue jay & 5 & 7 & 8 & 17 & 30 & 38 & 3 & 2 \\
\hline Chickadee (species?) & 16 & 15 & 13 & 8 & $-\ldots$ & $-{ }_{--}$ & 12 & 11 \\
\hline Great crested flycatcher & & 3 & 8 & 5 & 20 & 28 & 5 & 1 \\
\hline Red-eyed vireo & 14 & 11 & 7 & 3 & 5 & 8 & 8 & 7 \\
\hline Eastern wood pewee. & 9 & 6 & 9 & 10 & 5 & 10 & 8 & 3 \\
\hline Brown thrasher.............. & 3 & $\ldots$ & 2 & 10 & 30 & 15 & $\ldots$ & ... \\
\hline Downy woodpecker..... & 5 & 2 & 13 & 11 & 15 & 5 & 3 & 4 \\
\hline Common grackle & 8 & & $\ldots$ & 6 & 40 & & 2 & 1 \\
\hline Field sparrow & & 1 & 1 & 4 & $\ldots$ & 40 & 7 & 2 \\
\hline Brown-headed cowbird & 28 & $\ldots$ & 8 & 4 & --.- & & 5 & 8 \\
\hline Robin & 9 & 4 & $\ldots$ & 11 & 5 & 20 & 1 & \\
\hline Rufous-sided towhee..... & 4 & -.-- & 1 & 4 & 15 & 10 & 9 & 5 \\
\hline Common crow & 8 & 1 & 6 & 9 & & 13 & 9 & 1 \\
\hline Wood thrush & 1 & 1 & --- & 1 & 20 & 13 & 3 & 6 \\
\hline Acadian flycatcher & 1 & ---. & 5 & & & 5 & 17 & 12 \\
\hline Mourning dove & 1 & ---- & 1 & 12 & 10 & 8 & 3 & 2 \\
\hline Yellow-shafted flicker & 6 & 5 & 2 & 3 & 5 & 13 & $\ldots$ & $\cdots$ \\
\hline Red-headed woodpecker & 1 & 6 & 3 & 6 & 5 & 13 & ...- & \\
\hline American goldfinch & 8 & 7 & 3 & & 10 & $\ldots$ & 3 & 2 \\
\hline American redstart & $\ldots$ & 1 & 19 & 5 & -.-- & $\ldots$ & 3 & 2 \\
\hline Red-bellied woodpecker & $\ldots$ & -.- & 4 & 5 & 5 & 5 & 6 & + \\
\hline Carolina wren & $\ldots$ & $\ldots$ & 3 & 2 & $-\ldots$ & 5 & 8 & 11 \\
\hline Blue-gray gnatcatcher & 4 & $\ldots$ & 1 & 3 & -..- & $\ldots$ & 6 & 12 \\
\hline Yellowthroat & --- & 2 & & 1 & ...- & 18 & 4 & 1 \\
\hline Yellow-breasted chat & --- & $\ldots$ & 1 & $\ldots$ & 5 & 15 & 3 & 2 \\
\hline Eastern bluebird & 1 & 5 & --- & $\cdots$ & 10 & 5 & 2 & \\
\hline Kentucky warbler & --- & $\ldots$ & $-\ldots$ & 4 & -..- & $\ldots$ & 8 & 11 \\
\hline Ovenbird & 13 & 4 & 2 & 2 & $\ldots$ & $-\cdots$ & $\ldots$ & $\ldots$ \\
\hline Catbird & 3 & 2 & 2 & 12 & $\ldots$ & --.- & 1 & $\ldots$ \\
\hline House wren & 4 & 1 & 4 & 10 & .... & & -.. & $\ldots . .$. \\
\hline Bobwhite & -..- & $\ldots$ & -- & 2 & $\ldots$ & 10 & 1 & 2 \\
\hline Sparrow hawk & ---- & $\cdots$ & $\ldots$ & $-\ldots$ & 15 & --- & --- & $-\cdots$ \\
\hline White-eyed vireo & -.-- & ---- & $\ldots$ & $\ldots$ & $\cdots$ & ..... & 10 & + \\
\hline $\begin{array}{l}\text { Summer tanager } \\
\text { Bewick's wren }\end{array}$ & & ---- & - & ---- & 5 & & 5 & + \\
\hline $\begin{array}{l}\text { Bewick's wren } \\
\text { Ruby-throated hummingbird }\end{array}$ & $-\overline{1}$ & $--\overline{2}$ & -1 & 2 & -- & 13 & 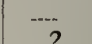 & 1 \\
\hline $\begin{array}{l}\text { Ruby-throated hummingbird } \\
\text { Hairy woodpecker }\end{array}$ & 1 & -.-- & 1 & 4 & $\ldots$ & ${ }^{3}$ & $\begin{array}{l}2 \\
2\end{array}$ & + \\
\hline Prothonotary warbler & $\ldots$ & $\ldots$ & -... & $\ldots$ & -- & 8 & 1 & 2 \\
\hline Red-tailed hawk & 5 & 1 & 1 & 2 & -.-- & -..- & & 1 \\
\hline Song sparrow & 3 & 1 & 3 & ---- & ...- & $\ldots . .$. & 3 & 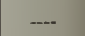 \\
\hline Starling & 10 & $\cdots$ & $\ldots-$ & $\ldots$ & .... & $\ldots$ & ... & $\ldots$ \\
\hline Redwinged blackbird & 5 & 2 & $-\ldots$ & ---- & --.- & -..- & 1 & 1 \\
\hline Belted kingfisher & & & -.-- & $-z_{0}$ & 5 & 3 & & - \\
\hline White-breasted nuthatch & 1 & 1 & $-\cdots-$ & 2 & $--\cdot-$ & $\cdots$ & 2 & 1 \\
\hline Worm-eating warbler & $\cdots$ & ... & ; & --- & -..- & -- & 6 & 1 \\
\hline $\begin{array}{l}\text { Cerulean warbler } \\
\text { Yellow-billed }\end{array}$ & $-\cdots$ & 1 & $\begin{array}{l}1 \\
2\end{array}$ & -- & $\cdots$ & $-\cdots$ & 3 & 2 \\
\hline Y ellow-billed cuckoo ...- & - & & & $\cdots$ & --- & 3 & $\cdots$ & 1 \\
\hline
\end{tabular}


Table 38.-Continued

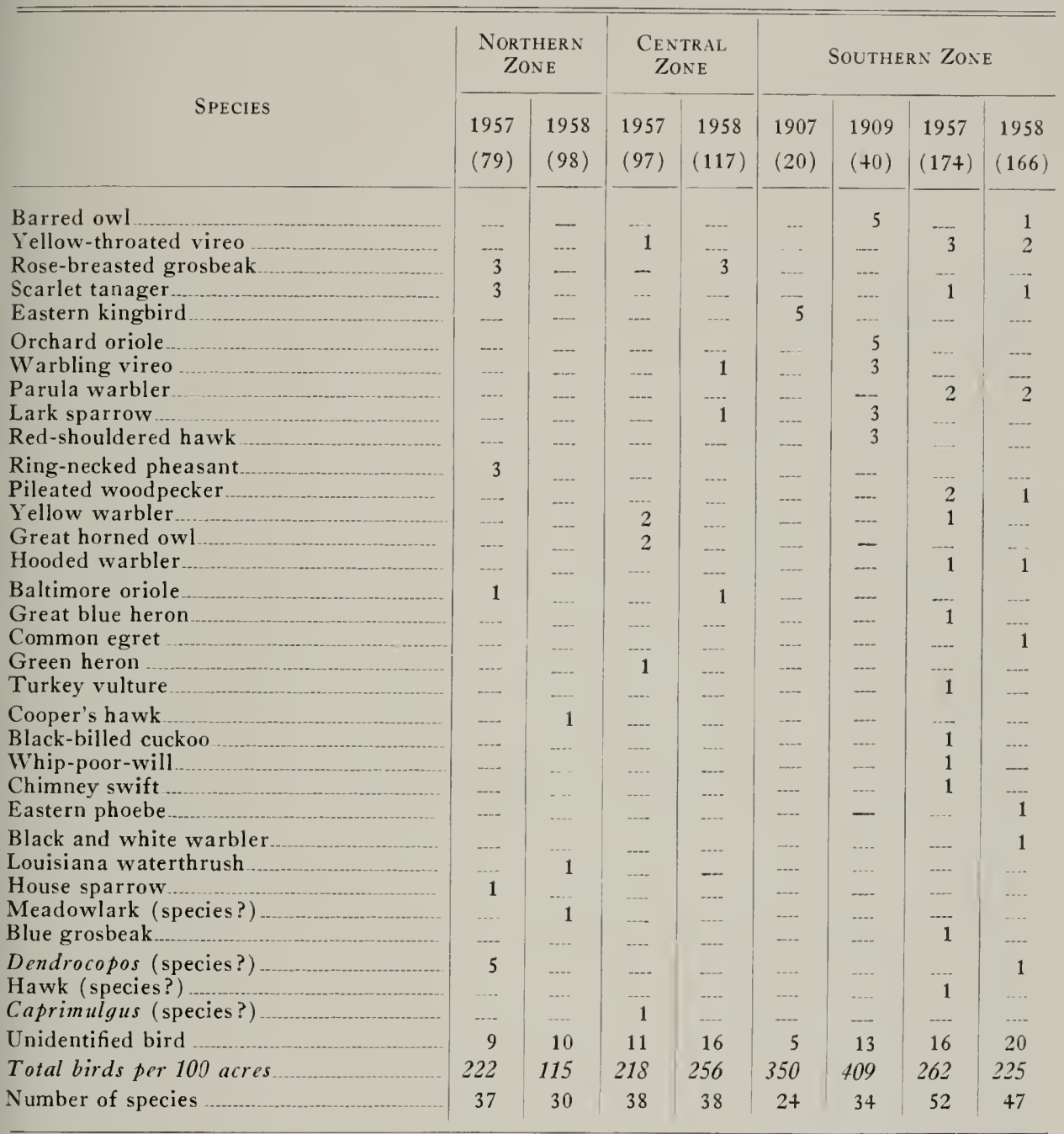

tive census years in one zone (northern Illinois) ranged from 1.1 to 2.2 , table 36 . In central Illinois, we found, population densities for woods with understory were 2.2 birds per acre in 1957 and 2.6 in 1958, table 36. Kendeigh and Kendeigh et al. (in Audubon Field Notes 1950-1960) presented data on the interior of a woodland in east-central Illinois showing that densities ranged from 151 to 275 territorial males per 100 acres in an 11-year period, 1950-1960. The population levels for all birds (both sexes) might have been twice as high. These data were from breeding-bird censuses. They sug- gest that our strip census figures are low. Our counts may have included relatively few of the females in the population.

Bird populations in forest with understory in southern Illinois in all census summers ranged from 2.2 to 4.1 birds per acre, table 36. A southern Illinois forest with understory, censused in 1907, is shown in fig. 21. The population figures for both the central and southern zones were conspicuously higher in 1907-1909 than in 1957-1958. This situation is in marked contrast to the situation in open-field habitats, where highest populations were recorded in the later censuses. The acreage 
Table 39.-Common birds (species making up approximately 85 per cent of birds counted in strip censuses) in woodlands with understory in Illinois, summers, 1957 and 1958.

\begin{tabular}{|c|c|c|c|c|c|}
\hline \multicolumn{2}{|l|}{ NoRTHERN ZONE } & \multicolumn{2}{|l|}{ Central Zone } & \multicolumn{2}{|l|}{ SOUTHERN ZONE } \\
\hline Species & $\begin{array}{l}\text { Per } \\
\text { Cent }\end{array}$ & Species & $\begin{array}{l}\text { Per } \\
\text { Cent }\end{array}$ & Species & $\begin{array}{l}\text { Per } \\
\text { Cent }\end{array}$ \\
\hline Chickadee (species?) & 15 & Cardinal & 14 & Cardinal $\ldots \ldots$ & 10 \\
\hline Brown-headed cowbird & 11 & Tufted titmouse. & 11 & Tufted titmouse & 9 \\
\hline Red-eyed vireo & 10 & Blue jay & 6 & Indigo bunting & 7 \\
\hline Cardinal & 8 & Downy woodpecker.... & 5 & Acadian flycatcher.... & 7 \\
\hline Ovenbird & 7 & Chickadee (species?) & 5 & Chickadee (species?) & 5 \\
\hline Dendrocopos (species?) & 5 & Eastern wood pewee.. & + & Carolina wren & 4 \\
\hline American goldfinch & 5 & Indigo bunting & + & Kentucky warbler........... & + \\
\hline Eastern wood pewee & + & Mourning dove.. & + & Blue-gray gnatcatcher... & + \\
\hline Indigo bunting & 3 & Robin & 3 & Red-eyed vireo & 3 \\
\hline Robin & 3 & Catbird & 3 & White-eyed vireo. & 3 \\
\hline Starling & 2 & American redstart & 3 & Rufous-sided towhee & 3 \\
\hline Red-tailed hawk & 2 & Brown-headed cowbird. & 3 & Brown-headed cowbird & 3 \\
\hline Common crow & 2 & Great crested flycatcher & 3 & Eastern wood pewee & 2 \\
\hline Blue jay & 2 & Brown thrasher & 3 & Wood thrush & 2 \\
\hline \multirow{2}{*}{$\begin{array}{l}\text { Ruby-throated humming- } \\
\text { bird }\end{array}$} & & Red-bellied woodpecker & 3 & Field sparrow & 2 \\
\hline & 1 & Red-headed woodpecker & 2 & Common crow & 2 \\
\hline Red-headed woodpecker & 1 & Common crow & 2 & Red-bellied woodpecker & 2 \\
\hline House wren & 1 & Red-eyed vireo & 2 & Summer tanager & 2 \\
\hline Catbird . & 1 & Common grackle & 2 & Worm-eating warbler & 2 \\
\hline \multirow[t]{7}{*}{ Blue-gray gnatcatcher } & 1 & Hairy woodpecker & 1 & Downy woodpecker & 2 \\
\hline & & Rufous-sided towhee & 1 & Mourning dove & 1 \\
\hline & & Field sparrow & 1 & Cerulean warbler & 1 \\
\hline & & & & $\begin{array}{l}\text { Yellow-throated vireo } \\
\text { American goldfinch. }\end{array}$ & $\begin{array}{l}1 \\
1\end{array}$ \\
\hline & & & & Blue jay & 1 \\
\hline & & & & American redstart ....... & 1 \\
\hline & & & & Yellow-breasted chat & 1 \\
\hline Total per cent & st & Total per cent & 85 & Total per cent & $\$ 5$ \\
\hline Number of species & 19 & Number of species & 22 & Number of species & 27 \\
\hline
\end{tabular}

Table 40.-Common birds (species making up approximately 85 per cent of birds counted) in woodlands in the northern zone of Illinois, summers, 1957 and 1958.

\begin{tabular}{|c|c|c|c|}
\hline \multicolumn{2}{|l|}{ WOODLANDS WITH UNDERSTORY } & \multicolumn{2}{|c|}{ WOODLANDS WITHOUT UNDERSTORY } \\
\hline Species & Per Cent & Species & Per Cent \\
\hline Chickadee (species?) & 15 & Common grackle & 48 \\
\hline Brown-headed cowbird & 11 & Yellow-shafted flicker & 6 \\
\hline Red-eyed vireo & 10 & Blue jay & 5 \\
\hline Cardinal ........... & 8 & Eastern bluebird & 4 \\
\hline Ovenbird & 7 & Eastern wood pewee & + \\
\hline Dendrocopos (species?) & 5 & Red-headed woodpecker & 3 \\
\hline American goldfinch & 5 & Redwinged blackbird & 3 \\
\hline Eastern wood pewee & + & American goldfinch .... & 3 \\
\hline Indigo bunting ... & 3 & Robin & 2 \\
\hline Rabin $\ldots$ & 3 & Common crow & 2 \\
\hline Starling & 2 & Starling & 2 \\
\hline Red-tailed hawk & 2 & & \\
\hline Common crow.............. & 2 & & \\
\hline Blue jay & 2 & & \\
\hline Ruby-throated hummingbird.. & 1 & & \\
\hline Red-headed woodpecker & 1 & & \\
\hline House wren & 1 & & \\
\hline $\begin{array}{l}\text { Catbird } \\
\text { Blue-gray gnatcatcher }\end{array}$ & 1 & & \\
\hline $\begin{array}{l}\text { Blue-gray gnatcatcher } \\
\text { Total per cent }\end{array}$ & & Total per cent & $\$ 2$ \\
\hline $\begin{array}{l}\text { Total per cent } \\
\text { Number of species }\end{array}$ & $\begin{array}{l}3 f \\
19\end{array}$ & Number of species & \\
\hline Number of species & & & \\
\hline
\end{tabular}


of forest censused in 1907-1909 was so small that the figures derived may not be representative.

At least 80 species representing 27 families of birds were identified in forest (both with and without understory), table 38 . The cardinal, indigo bunting, blue jay, red-eyed vireo, wood pewee, and downy woodpecker were recorded in all summers and zones in which censuses were made. Other species for which the frequency of occurrence was very high were tufted titmouse, crow, crested flycatcher, towhee, mourning dove, and wood thrush. Indications of increases in forest populations between 1909 and 1957 were shown by the chickadees, blue-gray gnatcatcher, Kentucky warbler, and white-eyed vireo, table

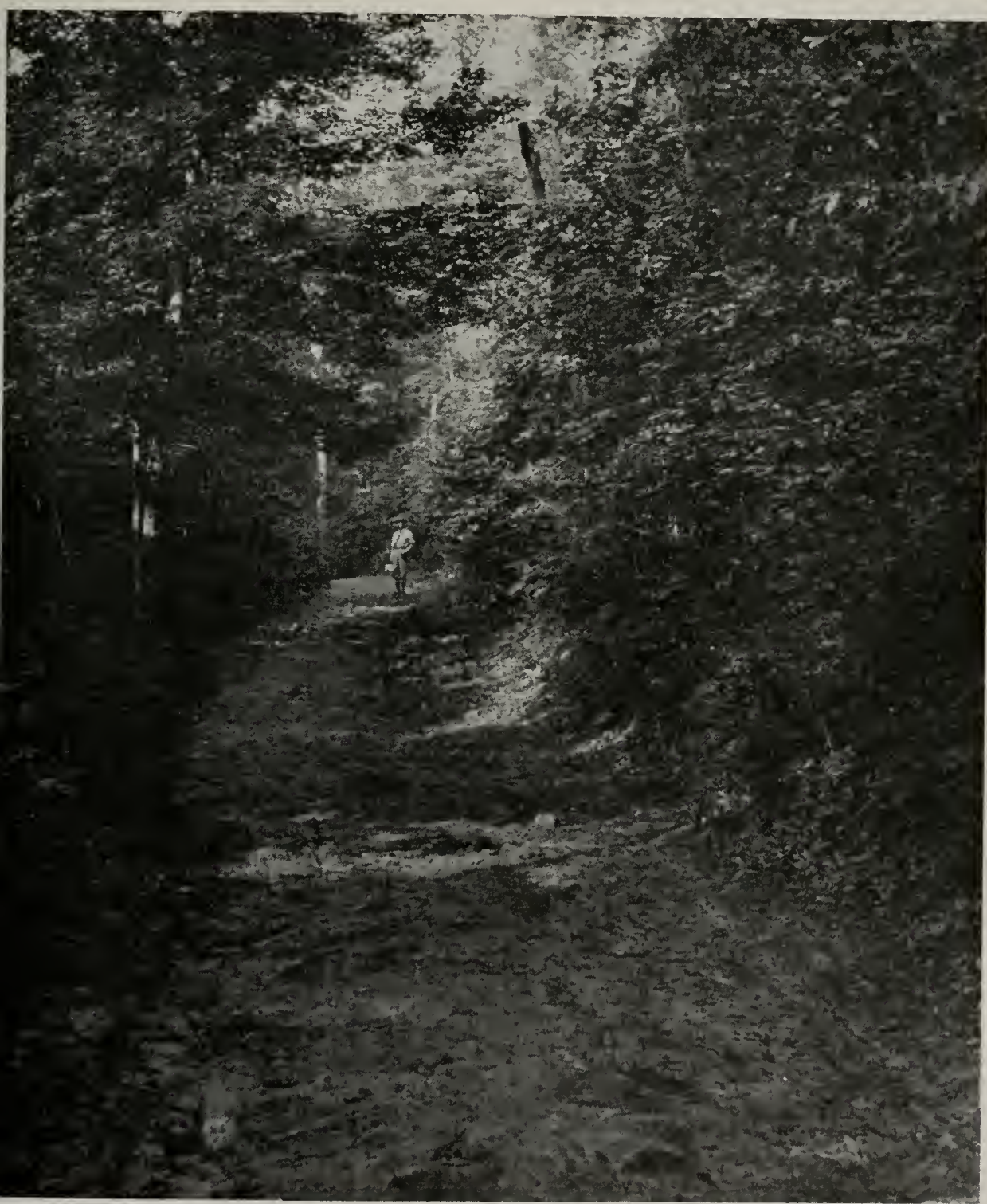

Fig. 21.-Forest with understory in southern Illinois censused in the summer of 1907. Such species as the summer tanager and wood thrush were recorded here. The photograph was taken east of Shetlerville, Hardin County, June 29, 1907, by Alfred O. Gross. 
3S. Species that showed some consistent marked population reduction between 1909 and 1957 were blue jay, crested flycalcher, wood thrush, brown thrasher, redheaded woodpecker, and yellow-shafted Hicker.

Lists of common forest species (species comprising $\$ 5$ per cent of the populations in forests with understory) in the three zones in the summers of 1957 and 1958 are presented in table 39 . The forest avifauna was progressively more varied from northern to southern latitudes. The numbers of common species in the southern zone were about the same in 1907-1909 as in 1957-1958 in spite of the much larger area covered in the later censuses.

'Though there were no consistent differences in density of bird populations between woods with understory and those lacking understory, tables 36 and 37 , there were qualitative differences, table +0 . 'The avifauna of the forest without understory was less varied, and the species composition was different in that such shrub-nesting and ground-nesting species as the cardinal and ovenbird were scarce or lacking in forest without understory.

\section{Urban Residential Areas (Summer)}

The spread of urban residential areas began long before the first strip censuses reported here, but the acreage of land occupied by human residences and lawns increased greatly after 1909 . We have estimated that acreage of this habitat climbed from about 350,000 acres in 1907 to 820 ,000 in 1957.

Only a small acreage of urban residential areas was censused in the summers of 1907-1909. In 1958, we made summer censuses in the residential areas of several

Table 41.-Summer avifauna in Illinois urban residential areas (birds per 100 acres) as determined by strip censuses in the three zones in 1958. Figures in parentheses indicate numbers of acres censused. Most of the species listed are known to nest in this habitat.

\begin{tabular}{|c|c|c|c|}
\hline SPECIES & $\begin{array}{l}\text { NORTHERN ZONE } \\
\qquad(160)\end{array}$ & $\begin{array}{c}\text { Central Zone } \\
\text { (75) }\end{array}$ & $\begin{array}{c}\text { SOUTHER Z ZONE } \\
\text { (98) }\end{array}$ \\
\hline House sparrow & 435 & 378 & 271 \\
\hline $\begin{array}{l}\text { Starling } \\
\text { Robin }\end{array}$ & 121 & 119 & 180 \\
\hline $\begin{array}{l}\text { Robin } \\
\text { Common grackle }\end{array}$ & 132 & 109 & 102 \\
\hline Common grackle & 96 & 27 & 22 \\
\hline Rock dove & 69 & 40 & 38 \\
\hline Mourning dove & 31 & 38 & 17 \\
\hline Purple martin & 25 & 11 & 42 \\
\hline Chimney swift & $1+$ & 27 & 24 \\
\hline Blue jay..._. & 16 & 16 & 21 \\
\hline House wren & 17 & 13 & 16 \\
\hline Catbird & 1 & 4 & 22 \\
\hline Cardinal & 6 & 4 & 9 \\
\hline Yellow-shafted flicker & 6 & 8 & 4 \\
\hline Brown thrasher & 1 & 4 & 3 \\
\hline Great crested flycatcher & ...- & --- & 5 \\
\hline Tufted titmouse & 3 & --- & 5 \\
\hline Chipping sparrow & 3 & $\ldots$ & 1 \\
\hline $\begin{array}{l}\text { Eastern wood pewee } \\
\text { Red-headed woodpecker }\end{array}$ & 1 & 1 & $\begin{array}{l}1 \\
2\end{array}$ \\
\hline Wood thrush & -- & $\cdots$ & 2 \\
\hline Warbling vireo & 1 & -.-- & 1 \\
\hline Downy woodpecker & 1 & - & 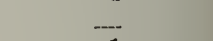 \\
\hline Mockingbird & $\cdots$ & -.-- & 1 \\
\hline Carolina wren & $\cdots$ & ---- & 1 \\
\hline Red-eyed vireo & 1 & --- & --- \\
\hline Brown-headed cowbird & $\cdots$ & 1 & $-{ }_{1}$ \\
\hline $\begin{array}{l}\text { Rufous-sided towhee } \\
\text { Song sparrow }\end{array}$ & $\cdots-$ & 1 & 1 \\
\hline $\begin{array}{l}\text { Unidentified bird } \\
\text { Unis }\end{array}$ & $\frac{1}{7}$ & $\begin{array}{l}1 \\
3\end{array}$ & 24 \\
\hline Total birds per 100 acres & 984 & 804 & 814 \\
\hline Number of species & 19 & 17 & 23 \\
\hline
\end{tabular}




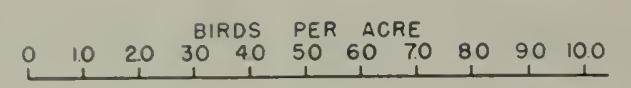

RESIDENTIAL

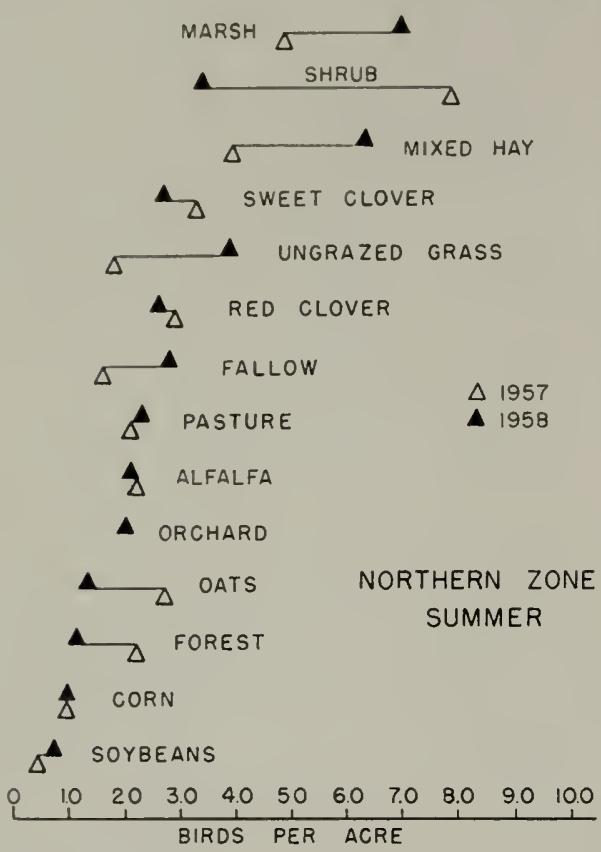

Fig. 22.-Densities of summer bird populations in a number of habitats in the northern zone of Illinois as determined by strip censuses in 1957 and 1958. The point of each triangle indicates the mean number of birds per acre for all fields of the habitat censused in the year and zone specified.

and zones) combined and include all birds seen and all acreages censused.

Number of Birds.--Of the 17 major summer habitats censused in the various years and zones, the row crops of corn and soyheans consistently supported the lowest bird populations; they had an average density of about 0.6 bird per acre. Plowed ground, oats, and wheat were also poor habitats for hirds; their average populations were $0.8,0.8$, and 0.9 bird per acre, respectively. Bird populations in oat fields showed marked increase between the 1909 and the 1957 censuses; populations were consistently low ( 0.6 bird per acre) in the early censuses, but relatively high in later years ( 1.7 birds per acre), primarily because of increases in the Icteridae. Populations in wheat fields showed no such change. Wheat, which is harvested earlier than oats, is a less attractive habitat.
Summer hird populations in grasilands and hay crops were variable, but usually conspicuously higher than in the barefield, row-crop, and small-grain habitats. For these, the average lird population levels (birds per acre) for all censuses were as follows: fallow fields, 1.6 ; pasture, 1.7 ; ungrazed grassland, 2.2 ; mixed hay, 2.2 ; alfalfa, 2.5 ; red clover, 2.8 ; and sweet clover, $t .1$.

Forests (all types) in summer supported populations of 2.t hirds per acre, about comparable to grasslands and hay habitats. 'The remaining habitats, shrubgrown areas ( 3.5 birds per acre), orchard (4.0), marsh (7.9), urban residential (8.9), and edge shrub (22.3), supported denser populations of birds.

In several habitats (plowed fields and row crops), the population of breeding species constituted only a relatively small part of the total population of these habitats in summer. Populations of breeding species were 0.2 bird per acre in corn and

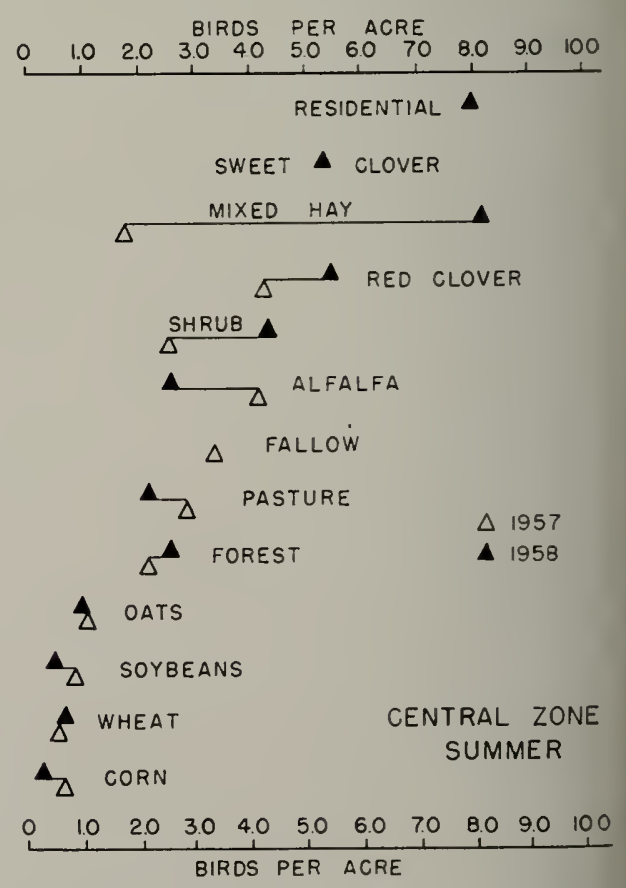

Fig. 23.-Densities of summer bird populations in a number of habitats in the central zone of Illinois as determined by strip censuses in 1957 and 1958. The point of each triangle indicates the mean number of birds per acre for all fields of the habitat censused in the year and zone specified. 
cies recorded were probably nesters; and virtually all of the 80 or more species found in forest probably nested there.

Residential areas, though a woody habitat, had a much more restricted summer avifauna, with $2 S$ species, table +1 , probably all of them nesting in this habitat.

In two habitats that were roughly similar, the population density tended to be higher in the hahitat in which the avifauna-hahitat relationship was more specialized and the avifauna was less varied. For example, residential areas, which had a more specialized avifauna-habitat relationship and a less varied avifauna than forests, had consistently higher population densities.

\section{Statewide Summer Populations}

A factor that must be considered in evaluating a particular habitat for birds is its total acreage. For instance, though ungrazed grasslands support a relatively high population of birds per unit of area, this high population density has little effect on the state population because of the very limited acreage of the habitat.

Extrapolating from the crop acreages presented by the Illinois Co-operative Crop Reporting Service (Ewing 1959), the U. S. Bureau of the Census (1913, 1961), and our census data, we can roughly estimate the total number of birds in a given habitat and also the total number of hirds in the state for the summers of 1909, 1957, and 1958 (no data for northern zone in 1907).

Illinois has a total land area of about $35,800,000$ acres. Ironically, the largest single habitat type in the state (row crops, principally corn and soybeans) is also one of the poorest of the bird habitats. If the censuses show the true distribution of hirds in the various hahitats of the state at given times, then in the summer of 1909 there were about $6,376,000$ birds in the row crops $(10,483,000$ acres $)$ : corn $(10$,173,000 acres) and garden vegetables $(310,000)$. By 1957, the land in corn (all types) had been reduced to about 8,280 ,000 acres, but another row crop, soybeans, had come into prominence and amounted to $4,979,000$ acres, while garden vegetables accounted for only 70,300 acres. The total area of row-crop habitat was thus increased by nearly $3,000,000$ acres over the
1909 acreage. In 1957, the total population of hirds in this habitat was estimated to he $8,170,000$, an increase of about 1,790,000 over the 1909 population.

The importance of the row-crop and plowed-field habitats as feeding grounds for birds is difficult to evaluate. 'The ultimate appraisal should be in terms of species survival, which is closely associated with nesting opportunity; in this frame of reference, the row crops have relatively little importance to the total avifauna. The expansion of row crops at the expense of other habitats represents a loss in both variety and numbers of birds.

Small grain crops in Illinois have decreased in acreage since 1909, when there were about $4,235,000$ acres of oats (plus rye) and the summer population in this habitat was estimated to be about 2,955,000 birds. In 1957, there were 2,990,000 acres of oats (plus rye) in Illinois; despite the decrease in acreage, the bird population in the habitat was estimated to be even higher than in $1909(5,552,000)$ because of an increase in population density in the habitat, particularly among the Icteridae in the northern half of the state. The acreage of wheat (plus barley) decreased from 2,250,000 in 1909 to 1,960 ,000 in 1957; the bird population in this habitat also decreased (1909: 1,494,000; 1957: 1,121,000).

By our estimate, the area of ungrazed grassland in Illinois decreased from ahout 331,000 acres in 1909 to 218,000 in 1957 , and the state bird populations in this habitat from 612,000 birds in 1909 to 464,000 in 1957.

We estimated that fallow fields in the state occupied 1,496,000 acres in 1909 and $1,034,000$ in 1957; our estimates of the populations in this habitat were $2,24+, 000$ birds in 1909 and 1,663,000 in 1957 .

In 1909, there were in Illinois about $6,085,000$ acres of nonwoodland sod pasture that contained a summer population estimated at 11,650,000 birds. In 1957, though over 2,000,000 acres of hay and other crops were used for pasture, sod pastureland amounted to only 1,965,000 acres; the bird population in this habitat was estimated to be $4,139,000,7,500,000$ below the 1909 population. Not all of the reduction represented breeding birds; if we consider breeding species only, the esti- 
mated number of birds in Illinois pastures decreased from $4,800,000$ in 1909 to 2,160,000 in 1957.

Coincidental with the loss in acreage of grassland, there was an increased use of cultivated hay plants for pasture in Illinois, and, in recent years, increased acreage of soil improvement (soil bank) hay. Thus, while the acreage of hay plants for harvest declined from $3,349,000$ acres in 1909 to $2,+59,000$ acres in 1957 , the total acreage of hay plants for all purposes was $5,25+, 000$ acres in 1957, an increase of 1,905,000 acres over the 1909 acreage. In the same period, there was some change in the types of hay produced. Alfalfa had a negligible acreage (18,000 acres) in 1909 , but it had become a leading hay crop $(1,+2+, 000$ acres $)$ by 1957 . Timothy, on the other hand, was planted on $1,870,000$ acres in 1909, while in 1957 there was very little acreage of pure timothy. In 1909 , timothy and mixed hay had about the same qualitative-quantitative avifaunal characteristics, and for final tabulation we lumped the census data for these crops. In all summer hay crops combined, the total summer population was estimated to be 6,834,000 birds in 1909 and 12,930,000 in 1957. For the most part, the increase represented increased acreage, for population densities in this habitat were similar over most of the state in 1909 and 1957. To some extent, the increase in hayfield acreage replaced the lost acreage in pastureland, but the gain in the hayfield bird population compensated for the loss in the pastureland population only in numbers of birds, not in variety of birds.

The amount of prairie (nonwood, nonshrub) marshland in Illinois decreased from about 558,000 acres in 1909 to about 60,000 acres in 1957 . The estimated total bird population for this rich habitat was $4,140,000$ in 1909 and 293,000 in 1957. These figures represent an estimated loss of $3,8+7,000$ birds in the population and, even more important, a loss in faunal variety. The marsh avifauna is highly varied and highly specialized, and most of the marsh species cannot survive in another habitat.

Based on our census data, the acreage of shrub-grown areas in $1909(469,000$ acres) was close to that in 1957 (507,000 acres). Despite the limited acreage, esti- mated summer bird populations were high in shrub-grown habitat: $1,993,000$ birds in 1909 and 1,892,000 in 1957.

In 1909, there were about 301,000 acres of Illinois orchards with an estimated summer population of $1,422,000$ birds. $\mathrm{By}$ 1957, when orchards had been reduced to about 31,000 acres, the estimated summer population $(108,000$ birds) in this habitat was negligible by comparison with the 1909 level. Though most species of orchard birds can survive in other habitats (shrub-grown areas and forest or woodlands), the loss is still regrettable. Probably much of this high-density habitat, which supported a varied avifauna, was replaced by poor-habitat crops, such as soybeans.

Forest or woodland acreage was probably greater in 1957 than in 1909, when there were, by our estimates, about 3,459 ,000 acres with a statewide summer population of $14,1+9,000$ birds. In 1957 , forests covered $3,996,000$ acres, but the statewide population of birds $(9,886,000)$ was estimated to be less (by $+, 261,000$ ) than in 1909 , because population densities in forests tended to be lower in the later years.

Acreages for urban residential areas in Illinois are not available for 1909 , but on the basis of the urban (human) population and acreage data for urban areas in later years, we estimate that there were about 350,000 acres of urban areas in Illinois in 1909. If the 1909 and 1957 bird population densities in this habitat were comparable to the 1958 level, when censuses were made, then the estimated summer population in 1909 was about 3,269,000 birds. By 1960, the acreage of urban areas had increased to about 820,000 acres and the bird population to about 7,657 ,000.

Commercial sections of urban areas have much smaller bird populations than residential sections. Virtually no native species are found in commercial areas; the avifauna of these areas consists almost entirely of the three introduced species (house sparrow, starling, and rock dove). Urban residential areas represent a modified forest habitat that can be an important reservoir for several species of native birds.

For all of the habitats mentioned, our estimates of the total statewide popula- 
tions of adult birds in summer were 57,138,000 in 1909 and $53,875,000$ in 1957. These data accounted for $33,368,000$ acres in 1909 and $32,290,000$ in 1957, leaving some of the acreage for the state unaccounted for: about 2,499,000 acres in 1909 and $3,505,000$ in 1957. In 1957, about 1,289,000 acres of land (excluding urban areas) were covered by the concrete, asphalt, or gravel of the state or federal highways and 14,000 additional acres were covered by railroad tracks and ties. Some road surfaces (especially gravel) may be of some value to birds, but, if we appraise in terms of species survival, road surfaces must be considered a void in the statewide acreage of bird habitats. Even after the acreage of these areas was included, there were still about 2,202,000 acres unaccounted for in 1957. Some of this acreage undoubtedly represented good bird habitats, such as cemeteries, grassy roadsides, and sod airfields, while part of it must have represented poor habitats, such as extraurban factories, other rural buildings, and paved airport runways. Included among the high-density habitats, as yet unaccounted for, were edge shrubs (estimated acreage in 1957: 86,000 ; estimated bird population in 1957: 1,918,000) and hedgerows (estimated acreage in 1957: 13,000; estimated bird population in 1957: 172,000); we lack comparative data on these habitats for 1909.

If our estimates are reasonably close to the actual numbers, there was little change in the total number of summer bird residents in the state between 1909 and 1957. If the acreage unaccounted for in 1909 and 1957 had harbored bird populations comparable to those in the acreage accounted for, then Illinois would have had state bird populations of about $61,333,000$ birds (mean density for state, 1.71 birds per acre) in 1909 and 59,778,000 birds (mean density for state, 1.67 birds per acre) in 1957. One possible explanation of the closeness of the 1909 and the 1957 populations is that the state land area has a saturation population level of about $60,000,000$ birds in summer and that this saturation level had been reached at least as early as 1909 . There is a limit to the mass of protoplasm that can be supported on a given land area. This mass of protoplasm could be expressed in terms of numbers of birds (and other animals) per unit area. It seems unlikely that the number of birds on a land area the size of Illinois would remain constant from year to year through the decades, even if a saturation level had been reached. Too many interdependent factors are involved -including the varied nature of the avifauna itself.

'To obtain data on year-to-year variations in the statewide bird population. we estimated the 1958 population, as well as the 1909 and 1957 populations; no data are available for the northern zone in 1907, and we did not estimate the state population for that vear. In the summer of 1958 , we estimated, there were $60,2+4$,000 birds on $32,806,000$ acres of 11 linois land ( $1.8+$ birds per acre), or, for the total acreage in the state, about $65,586, \mathrm{C} 00$ birds, about 5,600,000 more than in 1957 .

The 1957 and 1958 summer populations showed that the number of birds in the state may vary appreciably from one year to another even though the acreages of each habitat remain about the same. Appreciable variations in bird populations are to be expected. The population in one year depends on productivity in the previous year and on survival of birds in migration and on the wintering grounds. Because weather is variable, productivity (therefore population) may vary greatly. from year to year, as well as from habitat to habitat and from zone to zone. For 1957 and 1958, our estimates of bird populations in Illinois cornfields were, respectively, 5,705,000 and 5,397,000 birds. In the same period, the number of birds in oat fields changed drastically (1957: $5,552,000 ; 1958: 3,276,000)$. While the bird population in oat fields decreased, the population in wheat fields increased from 1957 to 1958 (from 1,121,000 to $2,+59,000)$. Both of these changes may have represented the same phenomenon, that is, a habitat shift by birds from one type of grain field to another.

Mean population densities varied somewhat from zone to zone. The northern zone consistently had the highest average density in summer. Mean densities in the summer (June) of 1909 were 2.0 birds per acre for the northern zone (2.5 in $1957,2 . t$ in 1958$) ; 1 . t$ for the central 
zone $(1 .+$ in $1957,1.7$ in 1958$)$; and 1.7 for the southern zone (1.4 in $1957,1.7$ in 1958). To some extent this variation reHects the lack of uniformity in distribution of such high-density habitats as urban residential areas, marsh, and forest. The relatively low mean density for the southern zone is surprising in view of the large acreage of forest in this zone.

The gross figures for the statewide summer population of birds include many species of birds, all of which have fluctuating populations. Population increases in one species might cancel decreases in another species. It is pointless to speculate further on the meaning of the gross changes until we have considered the individual species in more detail.

One generalization can be made here: that among the habitats considered-some primarily natural (prairie, forest, marsh) and some cultivated (corn and soybeans) - the 1909 summer bird populations tended to be higher in the natural habitats and the 1957 populations higher in the cultivated habitats.

\section{BIRD POPULATIONS IN WINTER HABITATS}

Bird populations in winter are much more variable than in summer, and comparison of results of the two sets of censuses as an index to long-term changes in the avifauna is somewhat tenuous.
During the winter season (December 1 -February 15), 10,180 acres of Illinois land were censused, 5.299 acres in 190607 and,+ 881 in 1956-57 and 1957-58. The acreages of each habitat covered in different regions and different winters are shown in table +3 . The habitats in order of descending acreage were corn, pasture, small grain stubble, wheat, harfield, forest, plowed ground, soybean stubble, fallow land, shrub-grown area, orchard, and marsh. The acreages of orchard and marsh were so small that we did not calculate the bird populations in them. The bird populations for the other types of habitat are discussed below. A comparison of bird population densities in various habitats is shown in figs. 25-27.

\section{Cornfields (Winter)}

The methods of corn harvesting have changed considerably since the first winter survey by Gross and Ray. Hand-picked fields, which comprised most of the cornfield acreage in the winter of 1906-07, were characterized by the tall cover of the standing stalks and by little grain left in the fields. Fields in which the stalks were cut offered little cover (except where there were shocks) and in this respect bore some resemblance to modern harvested fields. However, none of the early cornfield types was strictly comparable as a winter habitat to the cornfields of today. Mechanical

Table 43.-Acreages of habitats covered in winter strip censuses in the three zones of Illinois, 1906-07, 1956-57, and 1957-58.

\begin{tabular}{|c|c|c|c|c|c|c|c|}
\hline \multirow[b]{2}{*}{ TyPE OF HaBitaT } & \multicolumn{2}{|c|}{$\begin{array}{c}\text { NORTHERN } \\
\text { ZONE }\end{array}$} & \multicolumn{2}{|c|}{$\begin{array}{c}\text { Central } \\
\text { Zone }\end{array}$} & \multicolumn{2}{|c|}{$\begin{array}{c}\text { SOUTHERN } \\
\text { ZONE }\end{array}$} & \multirow{2}{*}{ Totur } \\
\hline & 1906-07 & $\begin{array}{l}1956-57 \\
1957-58\end{array} \mid$ & 1906-07 & $\left|\begin{array}{l}1956-57 \\
1957-58\end{array}\right|$ & 1906-07 & $\begin{array}{l}1956-57 \\
1957-58\end{array}$ & \\
\hline All corn & 734 & 329 & 516 & 759 & 281 & 277 & 2,899 \\
\hline Pasture & +40 & 109 & 371 & 156 & 181 & 93 & 1,350 \\
\hline Small grain stubble & 223 & 192 & 280 & 268 & 162 & 124 & 1,249 \\
\hline Wheat & 57 & 21 & $2+9$ & 237 & 289 & 293 & 1,146 \\
\hline Hayfield & 172 & 182 & 164 & 180 & 90 & 85 & 873 \\
\hline Forest & 65 & +5 & 50 & 152 & 241 & 211 & 764 \\
\hline Plowed ground & 269 & 68 & 125 & 86 & 18 & 93 & 659 \\
\hline Soybean stubble & & 28 & & 322 & 21 * & 126 & 497 \\
\hline Fallow field & 59 & 45 & 34 & 79 & 114 & 103 & +34 \\
\hline Shrub area & 18 & 13 & & 74 & 33 & 101 & 239 \\
\hline Orchard & 3 & 3 & 19 & 1 & 18 & 7 & 51 \\
\hline Marsh & $\ldots$ & 7 & .... & 4 & -... & 8 & 19 \\
\hline Total & $2,0+1$ & $1,0+2$ & 1,808 & 2318 & 1,750 & 1,521 & 10,180 \\
\hline
\end{tabular}




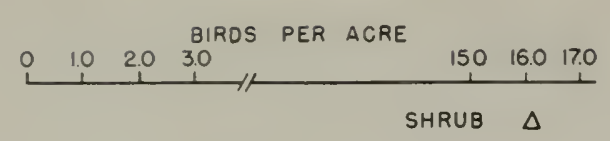

$\triangle$ FOREST

$\triangle$ FALLOW

$\triangle$ CORN STUBBLE

$\triangle$ SMALL GRAIN STUBBLE

$\triangle$ HAYFIELD

$\triangle$ PASTURE

$\triangle 1956-57$

$\triangle$ PLOWED

$\triangle$ WHEAT

NORTHERN ZONE WINTER

$\triangle$ SOYBEAN STUBBLE

$\begin{array}{llll}0 & 1.0 & 2.0 & 3.0\end{array}$ BIRDS PER ACRE

Fig. 25.-Densities of winter bird populations in a number of habitats in the northern zone of Illinois as determined by strip censuses in 1956-57. The point of each triangle indicates the mean number of birds per acre for all fields of the habitat censused in the year and zone specified.

picking of the grain leaves broken-over stalks and scattered grain throughout the fields. Modern cornfields in winter offer relatively little concealing or protective cover, but a considerable amount of food for some species of birds.

Of 2,896 acres of cornfields censused for birds in winter (all years), 1,18t acres represented fields that had been hand picked (1906-07), 25t acres were of fields from which the stalks had been cut and removed (1906-07), 93 acres had had the corn cut and shocked (1906-07), and 1,365 acres were of mechanically picked cornfields (1956-57 and 1957-58), tables $+t$ and 45 .

In the various types of cornfields, in all census years, winter bird populations tended to be most dense and most varied in the southern zone of the state, least dense and least varied in the northern zone, tables $t+$ and 45 . 'Two types of cornfield habitats, hand-picked (standing cornstalk) fields in 1906-07 and mechanically picked fields in 1956-57 and 1957-58. were especially important because each type occupied most of the corn acreage in its period.

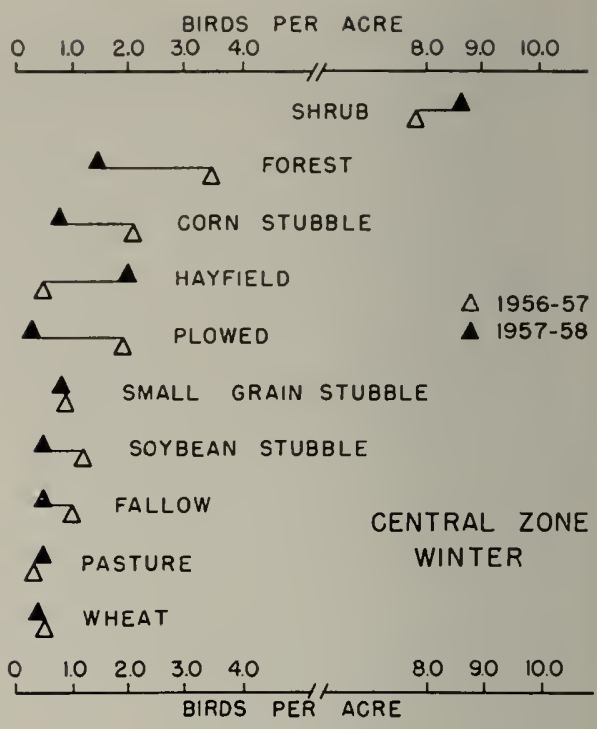

Fig. 26.-Densities of winter bird populations in a number of habitats in the central zone of Illinois as determined by strip censuses in 1956-57 and 1957-58. The point of each triangle indicates the mean number of birds per acre for all fields of the habitat censused in the year and zone specified.

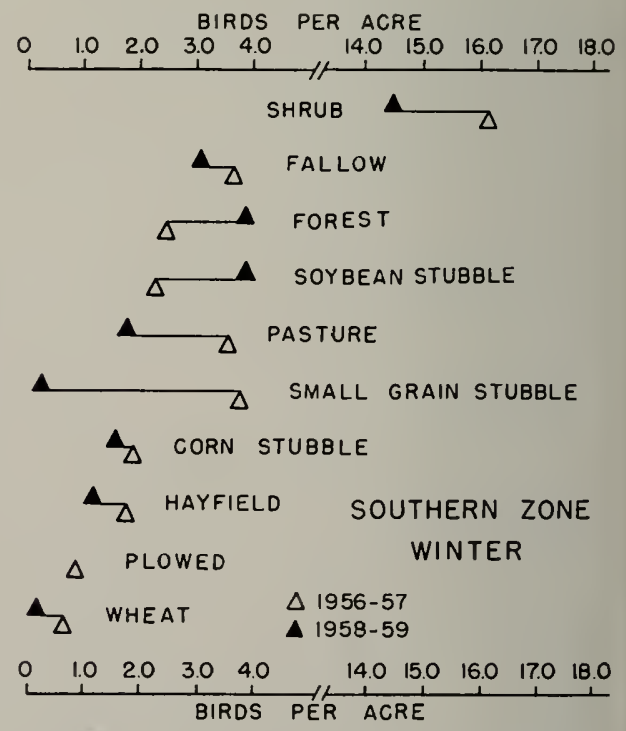

Fig. 27.-Densities of winter bird populations in a number of habitats in the southern zone of Illinois as determined by strip censuses in 1956-57 and 1957-58. The point of each triangle indicates the mean number of birds per acre for all fields of the habitat censused in the year and zone specified.

The term shrub in figs. 25-27 includes both shrub-grown areas and edge shrub. 
Quantitatively, bird populations in the two types were similar. Bird populations in hand-picked cornfields in the winter of 1906-07 (most of the censuses were in January) were 0.2 bird per acre (22 birds per 100 acres) in the northern zone, 1.t birds per acre (138 birds per 100 acres) in the central zone, and 2.0 birds per acre (203 birds per 100 acres) in the southern zone, table $4+$. Bird populations in mechanically picked cornfields in the winter of 1956-57 (most of the censuses were in January) were 0.5 bird per acre ( 50 birds per 100 acres) in the northern zone, 2.1 birds per acre (207 birds per 100 acres) in the central zone, and 1.9 birds per acre ( 188 birds per 100 acres) in the southern zone, table +5 .

Qualitatively, there were some important differences between the two periods with respect to the winter bird populations of cornfields. The winter avifauna of hand-picked fields (1906-07) was composed more of species that we usually think of as shrub or forest-edge inhabitants, while the winter avifauna of mechanically picked fields contained more prairie or open-field species, such as the horned lark and Lapland longspur. The taller cover of hand-picked fields (1906-07) was of

Table 44.-Winter avifauna in 11 linois cornfields of different types (birds per 100 acres) as deter mined by strip censuses in the three zones in 1906-07. In the first type, the ears have been picke and the stalks left standing; in the second, the stalks have been cut and shocked; in the third, th stalks have been cut and removed, leaving only short stubble. Figures in parentheses indicate num bers of acres censused; + indicates less than 1 bird per 100 acres.

\begin{tabular}{|c|c|c|c|c|c|c|c|c|c|}
\hline \multirow[b]{2}{*}{ SPECIES } & \multicolumn{3}{|c|}{ Northern ZONE } & \multicolumn{3}{|c|}{ Central Zone } & \multicolumn{3}{|c|}{ SOUTHERN ZONE } \\
\hline & $\begin{array}{c}\text { Ears } \\
\text { Picked } \\
(602)\end{array}$ & $\begin{array}{c}\text { Stalks } \\
\text { Cut and } \\
\text { Shocked } \\
(42)\end{array}$ & $\begin{array}{l}\text { Stalks } \\
\text { Cut and } \\
\text { Re- } \\
\text { moved } \\
(90)\end{array}$ & $\begin{array}{c}\text { Ears } \\
\text { Picked } \\
(360)\end{array}$ & $\begin{array}{c}\text { Stalks } \\
\text { Cut and } \\
\text { Shocked } \\
(49)\end{array}$ & $\begin{array}{c}\text { Stalks } \\
\text { Cut and } \\
\text { Re- } \\
\text { moved } \\
(107)\end{array}$ & $\begin{array}{c}\text { Ears } \\
\text { Picked } \\
(222)\end{array}$ & $\begin{array}{l}\text { Stalks } \\
\text { Cut and } \\
\text { Shocked } \\
(2)\end{array}$ & $\begin{array}{l}\text { Stalks } \\
\text { Cut anc } \\
\text { Re- } \\
\text { moved } \\
(57)\end{array}$ \\
\hline Common crow & 3 & $\ldots$. & .... & 125 & 22 & $\ldots$. & + & -.... & 10 \\
\hline Slate-colored junco & & -... & & 9 & $-\ldots$ & & 51 & & +7 \\
\hline Tree sparrow & 1 & $-\ldots$ & 5 & 1 & ---- & 11 & 2 & $\ldots$. & 40 \\
\hline Meadowlark (species?) & $\ldots$ & - & $\ldots$ & - & & & 59 & $\ldots$ & 5 \\
\hline Cardinal & $\ldots$ & .... & $\ldots$ & $\ldots$ & 38 & 1 & 3 & $\ldots$ & 7 \\
\hline Mourning dove & 1 & --- & $\ldots$ & + & & & 36 & $\ldots$ & ... \\
\hline Chickadee (species?) & + & - & .... & + & 4 & 2 & 3 & $\ldots$ & 14 \\
\hline House sparrow. & 7 & $\ldots$. & $\ldots$ & 1 & 16 & & 1 & & 2 \\
\hline Bobwhite & + & $\ldots$ & $\ldots$ & $\ldots$ & $\ldots$ & 7 & 16 & $\ldots$ & ... \\
\hline American goldfinch & 9 & $\ldots$ & 4 & $\ldots$ & $\ldots$. & $\ldots$ & 1 & & $\ldots$. \\
\hline Yellow-shafted Alicker. & $\ldots .$. & $\ldots .$. & $\ldots$ & $\ldots$ & $\ldots$ & & 8 & $=$ & 2 \\
\hline Song sparrow & $\ldots$ & $\ldots$ & $\ldots$ & + & $\ldots$ & $\ldots$ & 3 & -. & 5 \\
\hline Horned lark & -... & $\ldots$ & $\ldots$ & + & 4 & 2 & 1 & - . & \\
\hline Sparrow hawk & -... & $\ldots$ & $\ldots$. & $\ldots$ & 4 & 1 & + & - & 2 \\
\hline Downy woodpecker & + &..- & $\ldots$ & $\ldots$ & $\cdots$ & $\cdots$ & 1 & & 5 \\
\hline Eastern bluebird & $-\ldots$ & -..- & $-\cdots$ & $-\cdots$ & $\cdots$ & ... & 3 & $\ldots$ & 3 \\
\hline Carolina wren & $\ldots$ & $-\ldots$. & .... & $\ldots$ & .... & $\ldots$. & $\ldots$ & & 5 \\
\hline White-throated sparrow... & $\ldots$ & $-\ldots$. & -.-- & $-\cdots$ & $\ldots$ & $\cdots$ & + & $\cdots$ & $\cdots$ \\
\hline Blue jay & + & $\ldots$ & $\ldots$ & --- & 2 & $\ldots$ & 1 & $\ldots$ & $\cdots$ \\
\hline Red-bellied woodpecker & $\ldots$ & --- & --- & $-\cdots$ & 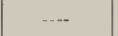 & $-\cdots$ & + & $\cdots$ & 3 \\
\hline Tufted titmouse & $\cdots$ & $-\cdots$ & $\ldots$ & $\ldots$ & $\ldots$ & $\ldots$ & & -... & 2 \\
\hline Turkey vulture & -... & $\cdots$ & $\cdots$ & $-\cdots$ & $-\ldots$ & $\ldots$. & 1 & $\ldots$ & $\cdots$. \\
\hline Robin & $\cdots$ & $\cdots$ & $\cdots$ & $-\cdots$ & $-\cdots$ & $\ldots$ & 1 & $-\ldots$ & $-\cdots$ \\
\hline Fox sparrow & + & $\cdots$ & $\cdots$ & $\cdots$ & $\cdots$ & $\ldots$ & 1 & -. & --- \\
\hline Rough-legged hawk & + & -- & $\cdots$ & $\cdots$ & -- & $\cdots$ & $\cdots$ & $\cdots$ & $\cdots$ \\
\hline $\begin{array}{l}\text { Red-headed woodpecker } \\
\text { Mockingbird }\end{array}$ & $\cdots$ & $\cdots$ & $-\cdots$ & $-\cdots$ & $-\cdots$ & $\cdots$ & + & $\cdots$ & $\ldots$. \\
\hline $\begin{array}{l}\text { Mockingbird } \\
\text { Loggerhead shrike }\end{array}$ & $\ldots$ & $-\cdots$ & --- & + & $\cdots$ & $\cdots$ & + & $\cdots$ & $\cdots$ \\
\hline $\begin{array}{l}\text { Loggerhead shrike } \\
\text { White-breasted nuthatch }\end{array}$ & $\ldots$ & $-\ldots$ & $\ldots$ & $\begin{array}{c}\top \\
\cdots\end{array}$ & $\ldots$ & $\ldots$ & + & $\cdots$ & $\ldots$ \\
\hline Hawk (species?) & ..... & $\ldots .$. & $\ldots$ & + & 2 & $\ldots$ & + & & $\ldots$ \\
\hline Total birds per 100 acres & 22 & $\ldots$ & 9 & 138 & 92 & 24 & 203 & $\ldots$ & 152 \\
\hline Number of species & 10 & $\ldots$ & 2 & 10 & 8 & 6 & 26 & $\ldots$ & 15 \\
\hline
\end{tabular}


no value to these open-field birds, and they were surely favored by the habitat changes that came with mechanical harvesting. In $1906-(17$, the cut fields, which should presumably have heen good habitat for the lark, had poor populations of these species. The winter data, like the data for summer, inclicate that the lark population increased wreatly between 1906-07 and 1956-57.

In cornfields of all types combined, at least $3 S$ species of birds were found in the winter census transects, tables $4+$ and 45 . As already indicated, the cornfield avifauna was an interesting combination of prairie and shrub or forest-edge species, the shrub species being particularly prom- inent in southern Illinois and in the handpicked fields of the first survey. For most of the winter birds, cornfields must be a marginal foraging habitat, for few species were found with great regularity in these fields. The tree sparrow was recorded in cornfields in all years and all zones except the northern zone in 1957-58 (in mechanically picked cornfields). Other inportant species of this winter habitat, from the standpoint of numbers of individuals seen or frequency of sightings, were the crow, junco (southern zone), and meadowlarks (southern zone) in most types of cornfields; the mourning dove, bobwhite, and chickadees in hand-picked cornfields; and the Lapland longspur and

Table 45.-Winter avifauna in Illinois harvested cornfields (birds per 100 acres) as determined strip censuses in the three zones. The 1906-07 figures are for fields in which cornstalks had been t by hand; figures for the other years are for fields mechanically picked. Figures in parentheses inate numbers of acres censused; + indicates less than 1 bird per 100 acres.

\begin{tabular}{|c|c|c|c|c|c|c|c|c|c|}
\hline \multirow[b]{2}{*}{ SPECIES } & \multicolumn{3}{|c|}{ Northers ZONe } & \multicolumn{3}{|c|}{ Central Zone } & \multicolumn{3}{|c|}{ SOUTHERN ZONE } \\
\hline & $\begin{array}{c}1906-07 \\
(90)\end{array}$ & $\begin{array}{c}1956-57 \\
(308)\end{array}$ & $\begin{array}{c}1957-58 \\
(21)\end{array}$ & $\begin{array}{c}1906-07 \\
(107)\end{array}$ & $\begin{array}{c}1956-57 \\
(491)\end{array}$ & $\begin{array}{c}1957-58 \\
(268)\end{array}$ & $\begin{array}{c}1906-07 \\
(60)\end{array}$ & $\mid \begin{array}{c}1956-57 \\
(154)\end{array}$ & $\begin{array}{c}1957-58 \\
(123)\end{array}$ \\
\hline $\begin{array}{l}\text { rned lark } \\
\text { te-colored junco }\end{array}$ & $\ldots$ & $1+$ & 9 & 2 & 90 & 24 & +7 & $\begin{array}{l}25 \\
26\end{array}$ & $\begin{array}{l}15 \\
94\end{array}$ \\
\hline and longspur & - & 18 & .... & & 107 & 42 & & & \\
\hline $\begin{array}{l}\text { ee sparrow } \\
\text { dwinged blackbird }\end{array}$ & 5 & 9 & $-\cdots$ & 11 & $\begin{array}{r}6 \\
\cdots-.-\end{array}$ & + & 40 & $\begin{array}{r}3 \\
57\end{array}$ & 2 \\
\hline adowlark (species?) & $\ldots$. & $\ldots$. & $\ldots-$. & $\ldots$ & + & $\ldots$ & 5 & 28 & 8 \\
\hline $\begin{array}{l}\text { Iling } \\
\text { sty blackbird }\end{array}$ & $\ldots$. & + & $\ldots$. & $\ldots$ & $\ldots$ & + & . & 26 & $\begin{array}{r}1 \\
26\end{array}$ \\
\hline 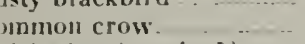 & $\cdots$. & 1 & .... & & -..- & $\ldots$. & 10 & 10 & $\ldots$ \\
\hline ickadee (species?) & .... & 1 & -... & 2 & - & $\cdots$ & 14 & & 1 \\
\hline $\begin{array}{l}\text { why woodpecker } \\
\text { ourning dove }\end{array}$ & $\ldots$. & $\stackrel{2}{2}_{+}^{-}$ & -.-- & $\ldots$ & $\begin{array}{l}1 \\
1\end{array}$ & + & 5 & 5 & $\begin{array}{l}1 \\
2\end{array}$ \\
\hline rdiual & $\ldots$ & & $\ldots$ & 1 & -.- & + & 7 & --- & $\ldots$ \\
\hline $\begin{array}{l}\text { use sparrow } \\
\text { biu }\end{array}$ & $\cdots$. & 3 & $\ldots$. & -.- & $\cdots$ & 3 & 2 & $\begin{array}{l}\cdots-\cdot \\
\cdots-\cdot\end{array}$ & 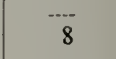 \\
\hline white $\quad \ldots$ & -. & - & $\cdots$ & 7 & $\cdots$ & & & & $\ldots$ \\
\hline $\begin{array}{l}\text { stern bluebird } \\
\text { rolina wrent. }\end{array}$ & $\cdots$ & - & $\cdots$ & $-\cdots$ & 1 & -... & $\begin{array}{l}3 \\
5\end{array}$ & $\begin{array}{l}2 \\
1\end{array}$ & $\cdots$ \\
\hline $\begin{array}{l}\text { nerican goldfinch } \\
\text { llow-shafted flicker }\end{array}$ & 4 & + & .... & -..- & + & --.- & 2 & 1 & $\begin{array}{l}1 \\
2\end{array}$ \\
\hline $\begin{array}{l}\text { d-bellied woodpecker } \\
\text { ng sparrow }\end{array}$ & $=$ & -.. & - & - & .... & + & $\begin{array}{l}3 \\
5\end{array}$ & 1 & 1 \\
\hline arrow hawk & - & & $\ldots$ & 1 & -..- & + & 2 & $\ldots$. & 1 \\
\hline $\begin{array}{l}\text { ng-necked pheasant } \\
\text { ifted titmouse. }\end{array}$ & . & 1 & $\cdots .$. & $\cdots$ & + & $\begin{array}{r}3 \\
-\cdots\end{array}$ & $\cdots$ & $\begin{array}{l}-\ldots . \\
\cdots--\end{array}$ & $\cdots$ \\
\hline $\begin{array}{l}\text { ort-eared owl } \\
\text { arsh hawk. }\end{array}$ & - & & $\ldots$ & $\ldots$ & + & 1 & $\ldots$ & 1 & $\ldots$ \\
\hline tailed hawk & $\cdots$. & & $\cdots$ & $\cdots$ & + & $\cdots$. & $\cdots \cdot$ & -- & - \\
\hline $\begin{array}{l}\text { innah sparrow } \\
\text { lentified bird }\end{array}$ & $\cdots$. & + & - & $\ldots$. & .... & $\cdots \cdot$ & $\cdots$ & $\overline{2}$ & $\cdots$ \\
\hline tal birds per 100 acres & 9 & 50 & 9 & 27 & 207 & 76 & 152 & 188 & 163 \\
\hline nber of species. & 2 & 12 & 1 & 6 & 12 & 11 & 15 & 13 & $1+$ \\
\hline
\end{tabular}


horned lark in mechanically picked cornfields.

\section{Soybean Stubble (Winter)}

The tremendous increase in acreage of soybeans after 1920 has already been discussed. All but 21 of the +97 acres of bean stubble censused in winter were covered in the second census period, table 43 ; some or all of these 21 acres may have been stubble of field beans. Most of the soy- bean acres censused were in central Illinois.

As a winter bird habitat, soybean stubble fields were more like cornfields than plowed ground and supported a similar avifauna. The average bird populations in the various zones and census years varied from almost zero to 3.9 birds per acre ( 4 to 387 birds per 100 acres, table 46 ); the populations were highest in the southern zone of the state.

Table 46.-Winter avifauna in Illinois soybean stubble fields (birds per 100 acres) as de termined by strip censuses in the three zones. Figures in parentheses indicate numbers of acres censused.

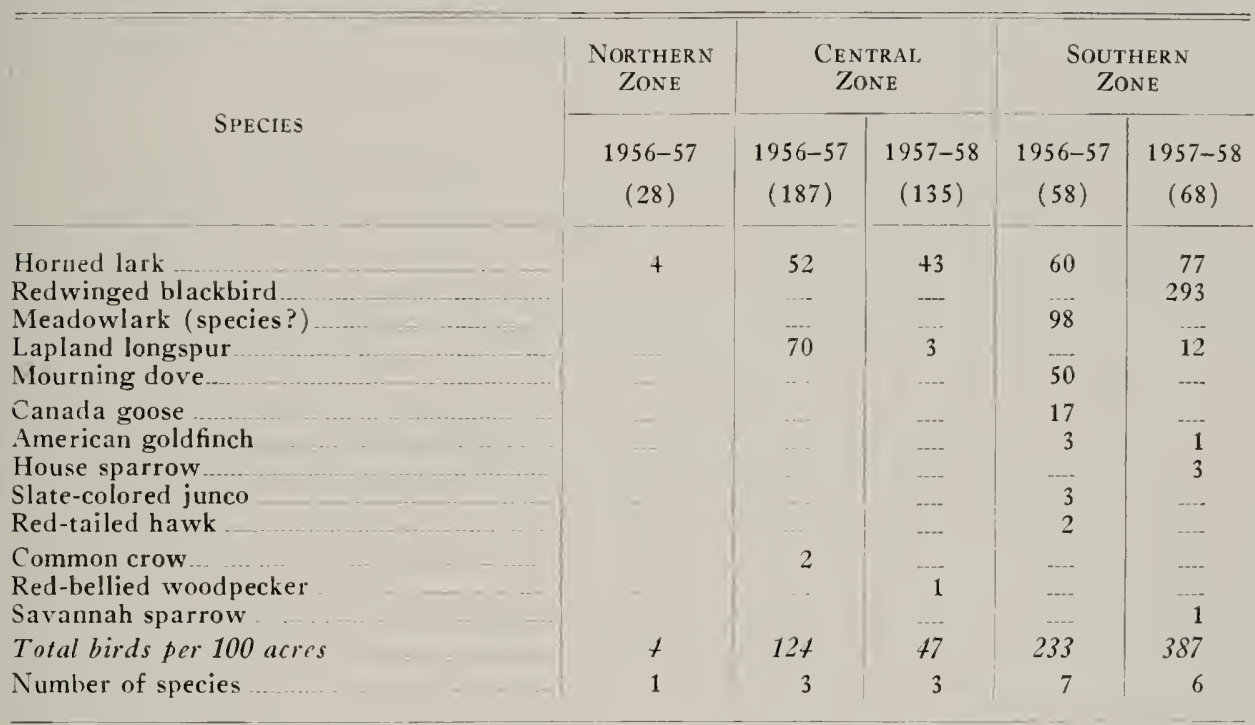

Table 47 .-Winter avifauna in Illinois plowed fields (birds per 100 acres) as determined by strip censuses in the three census zones. Figures in parentheses indicate numbers of acres censused; + indicates less than 1 bird per 100 acres.

\begin{tabular}{|c|c|c|c|c|c|c|c|c|}
\hline \multirow[b]{2}{*}{ SPECIES } & \multicolumn{2}{|c|}{ NORTHERN ZONE } & \multicolumn{3}{|c|}{ Central Zone } & \multicolumn{3}{|c|}{ SoUthern Zone } \\
\hline & $\begin{array}{c}1906-07 \\
(269)\end{array}$ & $\begin{array}{c}1956-57 \\
(68)\end{array}$ & $\begin{array}{c}1906-07 \\
(125)\end{array}$ & $\begin{array}{c}1956-57 \\
(46)\end{array}$ & $\begin{array}{c}1957-58 \\
(+0)\end{array}$ & $\begin{array}{c}1906-07 \\
(18)\end{array}$ & $\begin{array}{c}1956-57 \\
(43)\end{array}$ & $\begin{array}{c}1957-58 \\
(50)\end{array}$ \\
\hline $\begin{array}{l}\text { Horned lark } \\
\text { Slate-colored junco }\end{array}$ & 38 & 6 & 8 & 183 & 30 & $\cdots$ & $8+$ & 2 \\
\hline $\begin{array}{l}\text { Slate-colored junco } \\
\text { Lapland longspur. }\end{array}$ & 1 & 6 & 22 & 9 & .... & $\cdots$ & $\ldots$. & $\ldots$. \\
\hline House sparrow...... & 6 & ... & $\ldots$ & $\ldots$ & 5 & .... & & $\ldots$ \\
\hline Starling & & 1 & ... & $\ldots$ & & $\ldots$ & 2 & --- \\
\hline Chickadee (species?) & & & 2 & -..- & $\ldots$ & ---- & $\cdots-$ & ---- \\
\hline Tree sparrow & 1 & . & $\ldots$ & .... & .... & .... & .... & ...- \\
\hline $\begin{array}{l}\text { Yellow-shafted flicker } \\
\text { Hawk (species?) }\end{array}$ & + & & & $\ldots$. & & 16 & $\cdots$ & $\cdots$ \\
\hline Total birds per 100 acres & 46 & 13 & 32 & 192 & 35 & 16 & s6 & 2 \\
\hline Number of species & 5 & 3 & 3 & 2 & 2 & 1 & 2 & 1 \\
\hline
\end{tabular}


Of 13 species recorded in soybean fields, only the horned lark was found in all census winters and regions.

\section{Plowed Fields (Winter)}

In the two census periods, 659 acres of plowed fields were censused in winter, table 43 . For the various census years and zones, the bird populations varied from almost zero to 1.9 birds per acre (2 to 192 birds per 100 acres, table 47 ); the average was about 0.5 bird per acre. Populations averaged highest in central Illinois. In the southern zone, there was a striking difference between the bird populations of this habitat and those of cornfields. Birds occurred in much greater numbers and variety in corn stubble than in bare plowed fields, tables 45 and 47 .
At least nine species of birds were recorded within the plowed field transects in winter. The dominant species was the horned lark. The absence of cover appears to favor the horned lark; this one species comprised about 83 per cent of the statewide winter bird population seen on plowed ground. The Lapland longspur was recorded frequently in this habitat.

\section{Small Grain Stubble Fields (Winter)}

In terms of acreage, small grain stubble fields (wheat, oats, barley, rye) constituted the third largest winter habitat censused, table 43. About one-half of the $1,2+9$ acres censused were covered in 1906-07.

In the fields censused in winter, the stems of harvested wheat, oats, or other

Table 48.-Winter avifauna in 11 inois small grain stubble fields (birds per 100 acres) as deterned by strip censuses in the three zones. Figures in parentheses indicate numbers of acres cened; + indicates less than 1 bird per 100 acres.

\begin{tabular}{|c|c|c|c|c|c|c|c|c|c|}
\hline \multirow[b]{2}{*}{ SPECIES } & \multicolumn{3}{|c|}{ NORTHERn ZONE } & \multicolumn{3}{|c|}{ Central Zone } & \multicolumn{3}{|c|}{ SOUTHERn ZONe } \\
\hline & $\begin{array}{c}1906-07 \\
(223)\end{array}$ & $\begin{array}{c}1956-57 \\
(171)\end{array}$ & $\begin{array}{c}1957-58 \\
(21)\end{array}$ & $\begin{array}{c}1906-07 \\
(235)\end{array}$ & $\begin{array}{c}1956-57 \\
(137)\end{array}$ & $\begin{array}{c}1957-5 . \\
(131)\end{array}$ & $\begin{array}{c}1906-07 \\
(205)\end{array}$ & $\begin{array}{c}1956-57 \\
(54)\end{array}$ & $\begin{array}{c}1957-58 \\
(70)\end{array}$ \\
\hline $\mathrm{ng} \ldots \ldots \ldots$ & & 21 & $\ldots$ & - - & & 38 & $\ldots$ & 251 & 9 \\
\hline and longspur. & 72 & 19 & $\ldots$ & 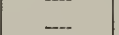 & 54 & & & .... & \\
\hline ed lark & 12 & 3 & 34 & 20 & 20 & 16 & 12 & -... & 3 \\
\hline adowlark (species?) & + & 2 & ---- & $\ldots$ & 9 & 3 & 25 & 80 & $\ldots$ \\
\hline non crow & 24 & 1 & $\ldots$ & 9 & 1 & 18 & 1 & -.-- & ..- \\
\hline white . . & 2 & ..- & ...- & 4 & ...- & $\ldots$ & 22 & $\ldots$ & $\ldots$ \\
\hline sparrow. & + & $\ldots$ & 14 & 1 & .... & 1 & 6 & 2 & \\
\hline sparrow & $\ldots$ & $\ldots$ & $\ldots$ & $\ldots$ & ---- & ..- & 4 & 9 & 7 \\
\hline mp sparrow & $\ldots$ & $\ldots$ & -.- & + & .... & $\ldots$ & 1 & 6 & 11 \\
\hline wn-headed cowbird. & $\ldots$ & $\ldots$ & --- & --- & -.-- & $\ldots$ & $\therefore$ & 19 & .... \\
\hline ise sparrow & 2 & $\ldots$ & $\ldots$ & 5 & 3 & $\ldots$ & ...- & $\ldots$ & $\ldots$ \\
\hline urning dove & $\ldots$ & .-- & 5 & $\ldots$ & .--- & ... & 1 & 2 & $\ldots$ \\
\hline Contc's sparrow....... & $\ldots$ & $\ldots$ & $\ldots$ & - & $\ldots$ & $\ldots$ & ---- & 7 & $\ldots$ \\
\hline Q-necked pheasant & ...- & 1 & $\ldots$ & --. & -.-- & 5 & --- & $\ldots$ & $\ldots$ \\
\hline tern bluebird & $\ldots$ & - & $\ldots$ & -. & --- & ---- & 4 & ...- & $\ldots$ \\
\hline annah sparrow & - & $\ldots$ & --- & $\ldots$ & $\ldots$ & .--- & .... & 4 & $\ldots$ \\
\hline rrow hawk & - & $\ldots$ & .... & $\ldots$ & .... & ..-- & 1 & .--- & 1 \\
\hline low-shafted flicker & - & 1 & $\ldots$ & - & $\ldots$ & $\ldots$. & 1 & ..-- & - \\
\hline rt-eared owl & $\ldots$ & .... & $\ldots$ & + & ..- & + & ... & ..-. & .... \\
\hline key vulfure & -.-- & -.- & -..- & --- & --- & $\ldots$ & 1 & -.- & $\ldots$ \\
\hline ailed hawk & $\ldots$ & ..... & .... & $\ldots$ & .... & $\ldots$ & 1 & $\ldots$ & $\ldots$ \\
\hline ellied woodpecker.... & $\ldots$ & -- & - & $\ldots$ & .... & .... & 1 & .... & - \\
\hline hy woodpecker & .... & $\ldots$ & $\ldots$ & .... & $\ldots$ & $\ldots$ & 1 & -.-- & $\ldots$ \\
\hline gerhead shrike.... & -.-- & -- & -- & - & --. & 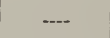 & 1 & --- & -- \\
\hline e-colored junco & -- & ---- & - & -- & --- & --- & 1 & $\cdots$ & $\ldots$ \\
\hline bunting & + & - & - & $\bar{t}$ & -- & -- & $\ldots$ & $\cdots$ & -+- \\
\hline ntified bird & 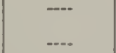 & $\bar{t}$ & $\ldots$ & $\begin{array}{l}+ \\
+\end{array}$ & $\ldots$ & $\ldots$ & 1 & 2 & $\cdots$ \\
\hline al birds per 100 acres & 113 & 48 & 53 & 40 & 87 & 81 & 85 & 382 & 31 \\
\hline nber of species & 8 & 7 & 3 & 8 & 5 & 7 & 17 & 9 & 5 \\
\hline
\end{tabular}


small grain, along with grass and weed growth of varying amounts, usually formed a fairly dense ground cover 6-12 inches in height, though often with some bare ground between rows.

Winter bird populations in this habitat were at least as variable in density as those in row crops and plowed fields. Populations in small grain stubble (all years and zones) ranged from 0.3 to 3.8 birds per acre (31 to 382 per 100 acres, table 48 ). In the second study period, populations averaged about 0.5 bird per acre in the northern zone, 0.8 in the central, and 1.8 in the southern. No consistent differences were apparent between population densities of 1906-07 and those of 1956-1958.

In the two study periods, at least 26 species of birds were identified within census strips in this winter habitat; the most varied avifauna was found in the southern zone, table $+S$. Species recorded in this habitat in the largest number of census winters and zones were the horned lark, crow, meadowlarks, and tree sparrow. Species recorded less frequently but in relatively large numbers in some years were the Lapland longspur and starling. Small grain stubble is not a particularly important habitat for any species of bird, but it probably serves regularly as a marginal foraging habitat for most of the species listed in table 48. Meadowlarks, which in Illinois wintered regularly in the row crops and plowed fields only in the southern zone, were found in small grain stubble fields even in the northern zone.

\section{Wheat Fields (Winter)}

Winter wheat is grown principally in the southern and central zones and in rela-

Table 49.-Winter avifauna in lllinois wheat fields (birds per 100 acres) as determined by strip cenuses in the three zones. Figures in parentheses indicate numbers of acres censused; + indicates less than 1 bird per 100 acres. No wheat fields in the northern zone were censused in the winter of $1957-58$.

\begin{tabular}{|c|c|c|c|c|c|c|c|c|}
\hline \multirow[b]{2}{*}{ SPECIES } & \multicolumn{2}{|c|}{ NORTHERN ZONE } & \multicolumn{3}{|c|}{ Central Zone } & \multicolumn{3}{|c|}{ SOUTHERn ZONE } \\
\hline & $\begin{array}{c}1906-07 \\
(57)\end{array}$ & $\begin{array}{c}1956-57 \\
(21)\end{array}$ & $\begin{array}{c}1906-07 \\
(203)\end{array}$ & $\begin{array}{c}1956-57 \\
(125)\end{array}$ & $\begin{array}{c}1957-58 \\
(112)\end{array}$ & $\begin{array}{c}1906-07 \\
(335)\end{array}$ & $\begin{array}{c}1956-57 \\
(163)\end{array}$ & $\begin{array}{c}1957-58 \\
(130)\end{array}$ \\
\hline Horned lark & 66 & & 1 & 21 & 37 & 4 & 24 & 2 \\
\hline Tree sparrow & $\ldots$ & & 2 & 24 & 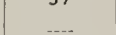 & $\ldots$ & - & \\
\hline Lapland longspur & -..- & 5 & $\ldots$ & 2 & $\cdots$ & -; & & 15 \\
\hline Meadowlark (species?) & .... & & $\ldots$ & & .... & 3 & 15 & 1 \\
\hline Starling & & & & & & & 12 & 1 \\
\hline Common crow & 7 & ... & 1 & 1 & 1 & & $\ldots$ & $\ldots$ \\
\hline Slate-colored junco. & $\ldots$ & & 5 & $\ldots$ & & 5 & & $\ldots$ \\
\hline House sparrow & $\therefore$ & & $\ldots$ & . & 3 & 1 & 4 & -... \\
\hline American goldfinch & $\ldots$ & 5 & .... & .. & $\ldots$ & $\ldots$ & 1 & ..... \\
\hline Canada goose & .... & $\ldots$ & $\cdots$ & 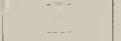 & $\cdots$ & $\cdots$ & + & ..... \\
\hline Eastern bluebird & $\ldots$ & $\ldots$ & $\ldots$ & & $\ldots .$. & 3 & $\ldots$ & $\ldots$ \\
\hline Sparrow hawk .... & $\ldots .$. & $\ldots$ & + & 1 & ..... & 1 & & ...- \\
\hline Mourning dove & … & $\ldots . .$. & $\ldots$ & $\ldots$ & ...- & + & 2 & ...- \\
\hline Brown-headed cowbird & ..... & $\cdots$. & $\cdots$ & $\cdots$ & -... & & 2 & .... \\
\hline Song sparrow & ..... & $\cdots$ & + & .... & ... & + & $\ldots$ & .... \\
\hline Marsh hawk & ......... & $\ldots$. & .... & $\ldots$. & $\ldots$. & $\ldots$ & $\ldots$ & 1 \\
\hline Killdeer ....... & $\ldots$ & ..... & $\cdots$ & … & ...- & -..- & -... & 1 \\
\hline Mockingbird & ..... & $\ldots$ & .... & ..... & $\ldots$ & 1 & & $\ldots$ \\
\hline Robin & -... & ... & $\ldots$ & $\cdots$ & $\ldots$ & 2 & 1 & ... \\
\hline Cardinal & ..... & .... & 1 & $\ldots .$. & $\ldots$ & & $\ldots$ & .... \\
\hline Turkey vulture & $\ldots$ & $\ldots$ & & $\ldots$. & $\ldots$. & + & & $\cdots$ \\
\hline Rough-legged hawk & -..- & ...- & + & $\cdots$ & ... & & $\ldots$ & -... \\
\hline Tufted titmouse & .... & ...- & .... & ... & $\ldots .$. & + & .... & ...- \\
\hline Unidentified bird & & $\ldots$. & & .... & ...- & + & $\ldots .$. & $\ldots$. \\
\hline Total birds per 100 acres & 73 & 10 & 11 & 49 & 41 & 20 & 66 & 20 \\
\hline Number of species & 2 & 2 & 8 & 5 & 3 & 11 & 10 & 5 \\
\hline
\end{tabular}


tively small acreage in the northern zone. In the two study periods, $1,1+6$ acres were censused in winter, table +3 ; the acreage was distributed about equally between the two census periods.

In winter, the cover in this habitat is a short (3-5 inches), dense stand of green plants. In the thickest stands, the mat is uniform and has no bare soil between rows, but in most fields some bare soil is apparent between rows.

Bird populations in winter wheat fields were generally low; the densities in different census winters and zones ranged from 0.1 to 0.7 bird per acre ( 10 to 73 birds per 100 acres, table 49 ). The numbers of birds in the central and southern zones were roughly comparable.

At least 23 species of birds were counted in the census strips of this winter habitat, table 49. The horned lark was the most abundant and most frequently sighted species. The Lapland longspur and tree sparrow were less numerous in this habitat than in the harvested cornfields, table 45.

The distribution of the meadowlarks in this winter habitat was similar to that in soybean stubble; that is, the birds were

Table 50.-Winter avifauna in Illinois pastures (birds per 100 acres) as determined by strip cenes in the three zones. Figures in parentheses in dicate numbers of acres censused; + indicates less n 1 hird per 100 acres.

\begin{tabular}{|c|c|c|c|c|c|c|c|c|c|}
\hline \multirow[b]{2}{*}{ Species } & \multicolumn{3}{|c|}{ Northern Zone } & \multicolumn{3}{|c|}{ Central Zone } & \multicolumn{3}{|c|}{ SOUTHERn ZONE } \\
\hline & $\begin{array}{c}1906-07 \\
(+40)\end{array}$ & $\begin{array}{c}1956-57 \\
(83)\end{array}$ & $\begin{array}{c}1957-58 \\
(26)\end{array}$ & $\begin{array}{c}1906-07 \\
(3+3)\end{array}$ & $\begin{array}{c}1956-57 \\
(38)\end{array}$ & $\begin{array}{c}1957-58 \\
(118)\end{array}$ & $\begin{array}{c}1906-07 \\
(208)\end{array}$ & $\begin{array}{c}1956-57 \\
(27)\end{array}$ & $\begin{array}{c}1957-58 \\
(66)\end{array}$ \\
\hline ed lark & 11 & 6 & 12 & 29 & 13 & 22 & 13 & 62 & 6 \\
\hline winged blackbird. & $\ldots$. & 1 & $\ldots .$. & & & & & 109 & \\
\hline e-colored junco ... & $\cdots$ & --- & $\cdots \cdot$ & 6 & & 6 & 14 & & $\begin{array}{r}76 \\
1\end{array}$ \\
\hline erican goldfinch & 22 & -... & -..- & 35 & & $\cdots$ & $\cdots$ & 11 & 1 \\
\hline tern bluebird & + & . & $\ldots$. & $\ldots$ & $\ldots$. & $\ldots$ & 7 & & 61 \\
\hline rling $\quad+\ldots$ & & 1 & .... & .... & .... & & & 51 & \\
\hline adowlark (species?) .... & .. & 1 & & & ..... & 2 & 9 & 4 & 30 \\
\hline e sparrow & 7 & & 15 & 1 & ...- & 5 & 1 & 4 & 1 \\
\hline ninon crow. & 6 & 6 & .... & 3 & ..... & .... & 2 & 15 & .... \\
\hline use sparrow & $1+$ & $\ldots$ & $\ldots$ & 1 & 8 & $\ldots$ & & 7 & $\ldots$ \\
\hline ple finch .... & . & $\ldots$. & & & & & 17 & $\ldots$ & - \\
\hline dinal & & ..... & + & 2 & 5 & 2 & 2 & $\ldots$ & $\ldots$ \\
\hline $\begin{array}{l}\text { low-shafted Hicker } \\
\text { white. }\end{array}$ & + & $\cdots$ & $\cdots$ & 1 & $\cdots$ & $\cdots$ & $\begin{array}{l}3 \\
9\end{array}$ & 4 & 1 \\
\hline lar waxıving & & ..... & $\cdots$ & $\cdots$ & -... & 8 & & $\cdots$ & $\ldots$ \\
\hline e jay ........... - - & 1 & & .... & + & 5 & & 2 & $\ldots$ & $\cdots$ \\
\hline -bellied woodpecker & & 1 & -..- & 2 & $\ldots$ & 2 & 1 & -..- & -.-- \\
\hline ckadee (species?) & + & .... & .... & 1 & .... & ... & $\cdots$ & .... & .... \\
\hline$g$ sparrow & & .... & .... & -... & .... & 1 & $\cdots$ & -..- & 3 \\
\hline rrow hawk & $\cdots$ & $\ldots$. & .... & $\ldots$. & 3 & $\ldots$ & 1 & $\ldots$ & $-\ldots-$ \\
\hline nmon grackle & . & $\ldots$ & .... & -... & $\ldots$. & & -... & 4 & \\
\hline land longspur & . & 1 & $\cdots$ & -... & $\cdots$ & 1 & $\cdots$ & -..- & 1 \\
\hline key vulture - & ....- & $\ldots .$. & $\ldots$ & ---- & … & ...- & 3 & -..- & -.. \\
\hline ck vulture & $\cdots$ & -..- & $\cdots$ & --- & ... & -- & .... & -... & 1 \\
\hline -railed hawk & $\cdots$ & $\ldots$. & $\cdots$ & $-\cdots$ & $\cdots-$ & $\cdots$ & 1 & -... & $-\ldots$ \\
\hline $\begin{array}{l}\text { parrow } \\
\text { vilwoodpecker }\end{array}$ & & -.- & $\cdots$ & + & $\cdots$ & 1 & --- & $\cdots \cdot$ & $-\cdots$ \\
\hline $\begin{array}{l}\text { why woodpecker } \\
\text {-shouldered hawk }\end{array}$ & + & $\cdots-$ & $\cdots$ & T & $\cdots$ & $\cdots$. & + & $\cdots$ & $\cdots$ \\
\hline ite-breasted nuthatch & .... & .... & -..- & + & & $\ldots$ & .... & $\ldots$ & $\ldots$ \\
\hline rsh hawk _ _ & $\ldots .$. & .... & -..- & + & & $\ldots$ & $\ldots$ & $\ldots$ & $-\cdots$ \\
\hline ry woodpecker & + & .... & .... & $\ldots$. & ... & .... & $\cdots$ & $\ldots$. & 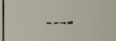 \\
\hline $\begin{array}{l}\text { wk (species?) } \\
\text { dentified bird }\end{array}$ & & $\cdots-\cdot$ & $\cdots$ & & -.-- & $\cdots$ & + & $\cdots$ & $\cdots$ \\
\hline $\begin{array}{l}\text { identified bird } \\
\text { al birds per } 100 \text { acres. }\end{array}$ & & & & & & 2 & + & 4 & 101 \\
\hline al birds per 100 acres.. & $6 \bar{\imath}$ & 17 & 31 & 82 & 34 & 52 & 85 & 359 & 181 \\
\hline nher of species & 11 & 7 & 3 & 14 & 5 & 10 & 16 & 10 & 11 \\
\hline
\end{tabular}


restricted to the southern zone in these habitats, although they had a more northern distribution in small grain stubble and some other habitats with taller cover.

\section{Pastures (Winter)}

In the two study periods, 1,350 acres of pastureland were censused in winter, most of them in 1906-07, table +3. Most of the pastures censused were stands of bluegrass with a few scattered, low woody plants. The grass cover was dense, even in winter, and 3-8 inches in height.
Bird populations of pastureland in different census winters and zones varied from 0.2 to 3.6 birds per acre ( 17 to 359 birds per 100 acres, table 50$)$; densities were lowest in the northern zone, highest in the southern. Population densities in pastureland varied less from zone to zone in 1906-07 than in 1956-1958; populations in the southern zone were conspicuously higher in 1956-1958 than in 190607. These data reflect a general trend: an increase in winter bird populations of southern Illinois since 1906-07.

Table 51.-Winter avifauna in Illinois fallow fields (birds per 100 acres) as determined by stri censuses in the three zones. Figures in parentheses indicate numbers of acres censused.

\begin{tabular}{|c|c|c|c|c|c|c|c|c|c|}
\hline \multirow[b]{2}{*}{ SPECIES } & \multicolumn{3}{|c|}{ Northers Zone } & \multicolumn{3}{|c|}{ Central Zone } & \multicolumn{3}{|c|}{ SOUTHERn Zone } \\
\hline & $\begin{array}{c}1906-07 \\
(59)\end{array}$ & $\begin{array}{c}1956-57 \\
(28)\end{array}$ & $\begin{array}{c}1957-58 \\
(17)\end{array}$ & $\begin{array}{c}1906-07 \\
(3+)\end{array}$ & $\begin{array}{c}1956-57 \\
(+5)\end{array}$ & $\begin{array}{c}1957-58 \\
(3+)\end{array}$ & $\begin{array}{c}1906-07 \\
(11+)\end{array}$ & $\begin{array}{c}1956-57 \\
(52)\end{array}$ & $\begin{array}{c}1957-5 \\
(51)\end{array}$ \\
\hline Slate-colored junco. & 26 & & & 78 & & & $1+$ & 193 & 39 \\
\hline $\begin{array}{l}\text { Tree sparrow } \\
\text { Bobwhite }\end{array}$ & 91 & 21 & 18 & 95 & 70 & 12 & 2 & 8 & 18 \\
\hline $\begin{array}{l}\text { Bobwhite } \\
\text { Starling }\end{array}$ & $\cdots$ & $1+$ & . & 33 & 16 & 33 & $\cdots \cdot$ & 52 & $\begin{array}{r}129 \\
+\end{array}$ \\
\hline American goldfinch & & & & $\cdots$ & 5 & -... & -... & 8 & +3 \\
\hline Horned lark & .... & 7 & 24 & $\ldots$ & 5 & 9 & 3 & 2 & \\
\hline Song sparrow & & + & & 9 & ....- & .... & 15 & & 18 \\
\hline Meadowlark (species?) & & & & & .... & .... & 3 & 31 & 6 \\
\hline Cardinal & & $\cdots$. & & 12 & $\cdots$. & ... & 6 & 6 & 10 \\
\hline Chickadee (species?) & 21 & ... & 6 & & ... & $\ldots$ & . & + & 2 \\
\hline Ring-necked pheasant & & $1+$ & 12 & -..- & $\cdots-$ & ...- & & & \\
\hline $\begin{array}{l}\text { Swamp sparrow } \\
\text { Field sparrow }\end{array}$ & & $\cdots$ & & $\ldots$ & -..- & --- & 1 & $\stackrel{2}{19}$ & 18 \\
\hline Eastern bluebird & & $\ldots$ & $\ldots$. & $\ldots$ & $\cdots$. & $\ldots$ & 3 & 12 & \\
\hline Downy woodpecker. & 3 & - & .... & 6 & $\ldots$ & .... & 3 & & $\ldots$ \\
\hline Le Conte's sparrow & & & $\ldots$. & $\ldots$. & $\ldots-$. & ...- & ...- & + & 8 \\
\hline $\begin{array}{l}\text { White-throated sparrow } \\
\text { Red-tailed hawk }\end{array}$ & $\cdots$ & & $\ldots$ & -..- & ...- & -..- & $\ldots$. & 10 & \\
\hline $\begin{array}{l}\text { Red-tailed hawk } \\
\text { House sparrow }\end{array}$ & $\ldots$ & + & $\cdots$ & --- & $\cdots$ & $\cdots-$ & 1 & 2 & \\
\hline Red-bellied woodpecker & .. & $\ldots$ & -..- & $-\ldots$ & 5 & $-\cdots$ & $\begin{array}{l}2 \\
1\end{array}$ & 2 & 2 \\
\hline Common crow & & & -... & $\ldots$ & -.-- & --- & 2 & 2 & . \\
\hline Sparrow hawk & $\ldots$ & t & $\ldots$ & -.-- & $\ldots$ & 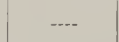 & $\ldots$. & .... & \\
\hline Mourning dove & & $\ldots$ & -..- & -..- & -..- & ...- & -..- & -..- & + \\
\hline Mockingbird & & ....- & -.... & -..- & $\cdots$ & $\ldots$ & -... & --- & + \\
\hline Short-eared owl & $\cdots$ & $\ldots-$ & $-\cdots-$ & $--\cdot$ & 2 &.-- & $\cdots$ & $\cdots-$ & \\
\hline Yellow-shafted flicker & $\cdots$. & ...- & $\cdots$ & -..- & $\cdots$ & $\ldots$. & 2 & $\ldots$ & $\ldots$ \\
\hline $\begin{array}{l}\text { Carolina wren } \\
\text { Long-billed marsh wren }\end{array}$ & -..- & $\ldots--$. & $\ldots .$. & .... & .... & ... & .... & 2 & $\cdots$ \\
\hline $\begin{array}{l}\text { Long-billed marsh wren } \\
\text { Robin }\end{array}$ & $\ldots$. & $\cdots-$ & $\cdots$ & $\cdots$ & $\cdots$ & ...- & -..- & 2 & 2 \\
\hline Loggerhead shrike & $\ldots$. & $\ldots-$. & .... & -..- & ...- & -.-- & -.-- & 2 & $\therefore$ \\
\hline White-crowned sparrow & $\ldots$. & ...-. & ....- & -..- & ... & $\ldots$ & .... & & 2 \\
\hline Fox sparrow & $\ldots$. & -...- & 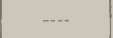 & -.- & ...- & -..- & $\ldots$ & 2 & \\
\hline Hairy woodpecker & $\ldots .$. & .... & $\cdots$. & -.. & .... & ...- & 1 & .... & ... \\
\hline $\begin{array}{l}\text { Blue jay } \\
\text { Melospiza (species?) }\end{array}$ & $\cdots$. & $\cdots$ & -... & $\cdots$ & $-\cdots-$ & $-\cdots-$ & 1 & $\cdots$ & $\cdots$ \\
\hline $\begin{array}{l}\text { Melospiza (species?) } \\
\text { Unidentified bird }\end{array}$ & $\ldots$. & $\ldots$ & $\cdots$ & -... & $\cdots$ & $\cdots$ & 1 & 2 & 2 \\
\hline Total birds per 100 acres & $1+1$ & 68 & 60 & 233 & 103 & $5 t$ & 61 & 373 & 311 \\
\hline Number of species & + & 7 & + & 6 & 6 & 3 & 16 & 21 & 16 \\
\hline
\end{tabular}


In the two census periods, at least 32 species of hirds were recorded in census strips of winter pastures, table 50 . The horned lark was the dominant species, occurring in all census years and zones. In our data, there is a suggestion of winter habitit change for this species. In 190607, population densities of the horned lark were consistently higher in grassland habitat than in row crops, while, in the second study period, the lark population was higher in row crops and plowed fields than in grassland. Other species prominent in winter pasture were the junco, goldfinch, meadowlarks, tree sparrow, crow, and cardinal.

\section{Fallow Fields (Winter)}

Fallow fields, cultivated fields that have been deserted, make good winter bird habitat, supporting a variety of species and large numbers of birds.

Only $+3 t$ acres of fallow fields were censused in winter, about half of the acreage in each census period and half of it in the southern zone, table +3 .

Winter bird populations in fallow fields in the different census zones and years varied from 0.5 to 3.7 birds per acre ( 54 to 373 birds per 100 acres, table 51). Highest populations were in the southern zone and lowest in the northern. In the northern and central zones, populations were conspicuously higher in the early study period, but, in the southern zone, they were higher in the later period. The same trends were apparent in winter bird populations of pastureland. These population differences between 1906-07 and 1956-1958 may he attributed largely to fluctuations in numbers of the junco and the tree sparrow and to a general increase in the winter bird population of southern Illinois since 1909.

In the two study periods, at least 34 species of birds were counted in winter census strips through fallow fields, table 51. Only the tree sparrow occurred in all years and all zones. The horned lark occurred in this habitat frequently, but in limited numbers. Other common species were the junco, bobwhite, and song sparrow. In southern Illinois, the meadowlarks, cardinal, swamp sparrow, and redbellied woodpecker were among the species found in every census year.

\section{Hayfields (Winter)}

Hayfields present a varied picture in winter, as the fields have been cut at various times in the previous summer or fall. Fields with short growth have an abundance of bare ground and are attractive to such species as the horned lark and Lapland longspur. Well-grown fields with taller (at least $S$ inches), more dense cover probably favor other species, such as the meadowlarks and bobwhite. In the two study periods, 873 acres of this hahitat were censused in winter-about half of the total in each period, table 43 .

Quantitatively, winter bird populations in hayfields compared roughly with those in mechanically picked cornfields, tables 45 and 52 . In the different zones and census years, populations varied from about 0.1 to 2.0 birds per acre ( 7 to 202 birds per 100 acres, table 52). As in most other habitats, populations in hayfields averaged highest in the southern zone, lowest in the northern. They averaged higher in late than in early censuses, at least partly because of greater numbers of horned larks.

At least 23 species were recorded in this winter habitat, table 52. The horned lark was the principal species; the meadowlarks and Lapland longspur occurred in large numbers in some zones and years.

\section{Shrub Areas (Winter)}

Shrubs comprise a rich habitat for birds in winter. The shrub areas (including edge shrubs) censused in the two study periods harbored dense populations and a variety of species. Only 239 acres of this habitat were censused, all but 51 acres in 1956-1958 and more than half of it in the southern zone, table +3 .

Bird populations in shrub areas in the different zones and census winters varied from 2.0 to 16.2 birds per acre (203 to 1,616 birds per 100 acres, table 53). Highest densities were in the southern and northern zones and in recent years. Sample sizes, which were small, may have tended to exaggerate the population density data. However, the 1906-07 census in this habitat consistently indicated markedly lower populations than those of the more recent census. 'To some extent, the apparent population differences between 1906-07 and 1956-1958 reflect actual population increases in a few species (for 
example, the cardinal) and also a general trend, observable in a number of species (for example, the mourning dove), for birds to winter farther north in larger numbers in the second than in the first survey period.

At least +2 species of birds were found in shrub census strips in winter, table 53. Among those recorded in several censuses and in large numbers were the tree sparrow, junco, house sparrow, cardinal, bobwhite, and starling.

\section{Forests (Winter)}

The Illinois woodlands censused in winter were very rich in species and also in numbers of birds, table 5t. In the two study periods, $76+$ acres of forest or woodlands were censused in winter, about 400 of these in 1956-1958; the largest acreage was in the southern zone, table +3 .

Total bird populations in different census winters and zones varied from $0 . t$ to 3.9 birds per acre ( 45 to 394 birds per
100 acres, table 5t). The populations averaged higher in the southern than in other zones. In the northern zone, the 1906-07 population was much lower than the populations recorded for recent years.

In the two study periods, at least +8 species of birds occurred in the forest strips censused in winter, table 5t. Among species found in several census years and zones were the junco, tree sparrow, chickadees, blue jay, cardinal, tufted titmouse, crow, goldfinch, red-bellied woodpecker, downy woodpecker, white-breasted nuthatch, song sparrow, and hairy woodpecker. The bobwhite, Carolina wren, robin, red-headed woodpecker, and yellow-shafted flicker were among the species found in every census year in the southern zone of Illinois.

\section{Comparison of Data for Winter Habitats}

Partly because of a breakdown in territorial behavior that occurs in winter,

Table 52.-Winter avifauna in Illinois hayfields (birds per 100 acres) as determined by strip censuses in the three zones. Figures in parentheses indicate numbers of acres censused.

\begin{tabular}{|c|c|c|c|c|c|c|c|c|c|}
\hline \multirow[b]{2}{*}{ SPECIES } & \multicolumn{3}{|c|}{ NORTHERN ZONE } & \multicolumn{3}{|c|}{ Central Zone } & \multicolumn{3}{|c|}{ SOUthern ZoNe } \\
\hline & $\begin{array}{c}1906-07 \\
(172)\end{array}$ & $\begin{array}{c}1956-57 \\
(1+5)\end{array}$ & $\begin{array}{c}1957-58 \\
(37)\end{array}$ & $\begin{array}{c}1906-07 \\
(164)\end{array}$ & $\begin{array}{c}1956-57 \\
(134)\end{array}$ & $\begin{array}{c}1957-58 \\
(+6)\end{array}$ & $\begin{array}{c}1906-07 \\
(90)\end{array}$ & $\begin{array}{c}1956-57 \\
(54)\end{array}$ & $\begin{array}{c}1957-58 \\
(31)\end{array}$ \\
\hline Horned lark & - & 21 & 38 & + & $3+$ & 71 & 2 & 6 & 26 \\
\hline Meadowlark (species?) &.- & 8 & $\ldots$ & . & 1 & & 55 & 22 & 68 \\
\hline Lapland longspur & $\ldots$ & 11 & $\cdots$ & $\ldots$ & 11 & 110 & & $\ldots$. & 6 \\
\hline Bobwhite & $\ldots$... & ... & $\cdots$ & . & $\ldots$ & .... & 20 & & 29 \\
\hline Slate-colored junco & $\ldots$ & $\ldots$ & $\ldots$ & 2 & 6 & $\cdots$ & $\cdots$ & 37 & $\ldots$ \\
\hline Eastern bluebird..... & $\ldots$. & $\ldots$ & $\ldots$ & --- & $\ldots$ & $\ldots$ & $\ldots$. & 9 & 20 \\
\hline Sprague's pipit & ... & $\ldots$ & $\cdots$ & $\ldots$ & & & $\cdots$ & 13 & 13 \\
\hline Starling & $\ldots$. & 1 & -... & $\ldots .$. & 1 & 21 & $\cdots$ & $\ldots$ & \\
\hline Mourning dove & $\cdots$ & $\ldots$ & $\cdots$ & $\cdots$ & 1 & --- & & & 23 \\
\hline Killdeer & $\ldots$ & $\ldots$ & $\ldots .$. & $\ldots$ & $\ldots$ & $\cdots$ & 5 & 18 & $\cdots$ \\
\hline American goldfinch & 1 & 1 & $-\cdots$ & & & $\ldots .$. & $\cdots$ & 13 & $\cdots$ \\
\hline Tree sparrow & 2 & t & .... & & 1 & $\cdots-$ & $\ldots$ & -- & $\cdots$ \\
\hline Common crow & 3 & 1 & -.- & 1 & $\cdots$ & $\ldots$ & $\cdots$ & $\cdots$ & $\cdots-$ \\
\hline Song sparrow & $\ldots$. & 1 & $\cdots$ & & $\cdots$ & $\cdots$ & 2 & $\cdots$ & $\cdots-$. \\
\hline Yellow-shafted Hicker & $-\cdot$. & & $\ldots$ & 1 & .. & $\cdots$ & 1 & -.- & -- \\
\hline Blue jay & $\cdots$ & $\ldots$ & $\ldots$. & 2 & $\cdots$ & $\ldots$ & 2 & $\ldots$ & $\ldots .$. \\
\hline Chickadee (species?) & $\cdots$ & $\cdots$ & $\ldots$. & $\cdots$ & $\cdots$ & 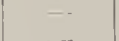 & $\begin{array}{l}2 \\
1\end{array}$ & $\cdots$ & $-\cdot$ \\
\hline Turkey vulture & $\ldots$. & $\cdots$ & $\cdots$ & 1 & $\cdots$ & $\cdots$ & 1 & $\cdots$ & $\cdots$ \\
\hline $\begin{array}{l}\text { Rough-legged hawk } \\
\text { Sparrow hawk }\end{array}$ & $\cdots$ & $\cdots+$ & $\cdots$ & $\begin{array}{l}1 \\
1\end{array}$ & $\cdots-$ & $\cdots$ & $\cdots$ & $\cdots$ & $\ldots$ \\
\hline $\begin{array}{l}\text { Sparrow hawk } \\
\text { Ring-necked pheasant }\end{array}$ & & 1 & $\cdots$ & $\ldots$ & $\ldots .$. & 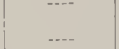 & $=$ & ...... & \\
\hline $\begin{array}{l}\text { Ring-necked pheasant } \\
\text { Downy woodpecker }\end{array}$ & $\cdots$ & 1 & $\cdots$ & . & $\cdots$ & $\cdots+$ & . & $\cdots$ & -... \\
\hline $\begin{array}{l}\text { Downy woodpecker } \\
\text { House sparrow }\end{array}$ & 1 & $\ldots$ & $\ldots$ & & $\ldots$ & .... & & $\cdots$ & -..- - \\
\hline $\begin{array}{l}\text { House sparrow } \\
\text { Hawk (species?) }\end{array}$ & 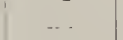 & . & & 1 & & .... & 1 & $\cdots$ & -..- \\
\hline Total birds per 100 acres & 7 & 50 & 38 & 13 & 55 & 202 & 89 & 118 & 185 \\
\hline Number of species .. & + & 10 & 1 & 7 & 7 & 3 & 8 & 7 & 7 \\
\hline
\end{tabular}


bird populations at this time of year tend to have "i definitely "clumped" distribution. At this season. large areas of a particular habitat may be void of birds, while the birl population of the habitat may be
Hocked in relatively small areas. At this season, also, birds tend to range farther and to be less restricted to a particular habitat than in summer. The avifaunal characteristics of a given habitat are thus

Table 53.-Winter avifauna in Illinois shruh areas (birds per 100 acres) as determined hy strip censuses in the tliree zones; the figures include edge shruhs. Figures in parentheses indicate numbers of acres censused.

\begin{tabular}{|c|c|c|c|c|c|c|c|}
\hline \multirow[b]{2}{*}{ SPECIES } & \multicolumn{2}{|c|}{ VORTHERN ZONE } & \multicolumn{2}{|c|}{ Central ZoNe } & \multicolumn{3}{|c|}{ SUUTHERN ZONE } \\
\hline & $\begin{array}{c}1906-07 \\
(18)\end{array}$ & $\begin{array}{c}1956-57 \\
(13)\end{array}$ & $\begin{array}{c}1956-57 \\
(39)\end{array}$ & $\begin{array}{c}1957-58 \\
(35)\end{array}$ & $\begin{array}{c}1906-07 \\
(33)\end{array}$ & $\begin{array}{c}1956-57 \\
(60)\end{array}$ & $\begin{array}{c}1957-58 \\
(+1)\end{array}$ \\
\hline $\begin{array}{l}\text { Tree sparrow } \\
\text { Slate-colored junco } \\
\text { House sparrow } \\
\text { Bobwhite } \\
\text { Cardinal }\end{array}$ & $\therefore$ & $\begin{array}{r}1,002 \\
32 \\
388 \\
158 \\
\ldots\end{array}$ & $\begin{array}{r}+60 \\
8+ \\
1+3 \\
\overline{18}\end{array}$ & $\begin{array}{r}301 \\
136 \\
69 \\
1+ \\
52\end{array}$ & $\begin{array}{r}9 \\
73 \\
+2 \\
112 \\
3\end{array}$ & $\begin{array}{r}191 \\
2+5 \\
91 \\
73 \\
98\end{array}$ & $\begin{array}{r}113 \\
681 \\
7 \\
83\end{array}$ \\
\hline $\begin{array}{l}\text { Starling } \\
\text { Mourning dove } \\
\text { Redwinged blackbird } \\
\text { Robin } \\
\text { Chickadee (species?) }\end{array}$ & +5 & $\cdots$ & 25 & $\begin{array}{r}116 \\
9 \\
9\end{array}$ & $\cdots$ & $\begin{array}{r}100 \\
20 \\
290 \\
87 \\
12\end{array}$ & $\begin{array}{r}12 \\
2+0 \\
39 \\
25\end{array}$ \\
\hline $\begin{array}{l}\text { Cedar waxwing } \\
\text { Blue jay } \\
\text { Song sparrow } \\
\text { White-crowned sparrow } \\
\text { American goldfinch }\end{array}$ & 68 & $\begin{array}{c}8 \\
- \\
\cdots\end{array}$ & $\begin{array}{r}5 \\
5 \\
2\end{array}$ & $\begin{array}{r}12+ \\
3 \\
\cdots \\
\cdots\end{array}$ & 6 & $\begin{array}{r}8 \\
+5 \\
101 \\
30\end{array}$ & $\begin{array}{r}12 \\
+7 \\
2 \\
66\end{array}$ \\
\hline $\begin{array}{l}\text { Downy woodpecker } \\
\text { Red-bellied woodpecker } \\
\text { Brown-headed cowbird } \\
\text { Eastern bluebird } \\
\text { White-throated sparrow }\end{array}$ & $\begin{array}{c}\cdots \\
\cdots\end{array}$ & $\begin{array}{c}\cdots \\
\cdots \\
\cdots-\end{array}$ & $\begin{array}{r}15 \\
2 \\
\cdots\end{array}$ & $\begin{array}{r}6 \\
9 \\
\cdots \\
\cdots-\end{array}$ & $\begin{array}{c}3 \\
3 \\
9\end{array}$ & $\begin{array}{l}13 \\
18 \\
50 \\
21 \\
28\end{array}$ & $\begin{array}{r}5 \\
15 \\
-5 \\
7\end{array}$ \\
\hline $\begin{array}{l}\text { Mockingbird } \\
\text { Purple finch } \\
\text { Common crow } \\
\text { Fox sparrow } \\
\text { Carolina wren }\end{array}$ & $\begin{array}{c}\cdots \\
\cdots \\
\cdots \\
\cdots\end{array}$ & 16 & $\begin{array}{l}\cdots . \\
\cdots \\
\cdots \\
\cdots\end{array}$ & 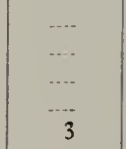 & $\begin{array}{r}27 \\
9\end{array}$ & $\begin{array}{r}3 \\
2 \\
7 \\
7\end{array}$ & $\begin{array}{c}29 \\
\cdots \\
\cdots\end{array}$ \\
\hline $\begin{array}{l}\text { Rufous-sided towhee } \\
\text { Sivamp sparrow... } \\
\text { Tufted titmouse } \\
\text { Hairy woodpecker } \\
\text { Field sparrow }\end{array}$ & 11 & $\begin{array}{l}\cdots . . \\
\cdots \\
\cdots \\
\cdots\end{array}$ & 2 & 3 & 6 & $\begin{array}{l}7 \\
7 \\
2 \\
5\end{array}$ & $\begin{array}{l}5 \\
7 \\
5\end{array}$ \\
\hline $\begin{array}{l}\text { White-breasted nuthatch } \\
\text { Long-eared owl } \\
\text { Yellow-shafted flicker } \\
\text { Loggerhead shrike } \\
\text { Meadowlark (species?) }\end{array}$ & $\begin{array}{c}6 \\
\cdots \\
\cdots\end{array}$ & $\begin{array}{l}\cdots \\
\cdots \\
\cdots \\
\cdots \\
\cdots\end{array}$ & 2 & $\frac{-}{6}$ & $\begin{array}{c}3 \\
\cdots \\
\cdots\end{array}$ & $\begin{array}{l}2 \\
2 \\
7\end{array}$ & 5 \\
\hline $\begin{array}{l}\text { Ruby-crowned kinglet } \\
\text { Myrtle warbler } \\
\text { Harris' sparrow } \\
\text { Marsh hawk } \\
\text { Sparrow hawk }\end{array}$ & 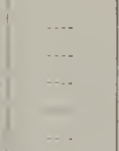 & $\begin{array}{l}\cdots \\
\cdots \\
\cdots \\
\cdots\end{array}$ & a.. & 3 & $\begin{array}{l}\cdots \\
\cdots \\
\cdots \\
\cdots\end{array}$ & $\begin{array}{r}2 \\
2 \\
\cdots \\
2\end{array}$ & $\begin{array}{r}2 \\
2 \\
2 \\
2 \\
\cdots\end{array}$ \\
\hline $\begin{array}{l}\text { Saw-whet owl } \\
\text { Hermit thrush } \\
\text { Melospiza (species?) } \\
\text { Zonoirichia (species?) } \\
\text { Unidentified bird }\end{array}$ & $\cdots$ & $\begin{array}{c}\cdots \\
\cdots \\
\cdots \\
8\end{array}$ & 2 & 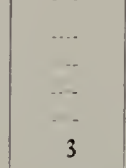 & $\begin{array}{l}\cdots \\
\cdots \\
\cdots-. \\
\cdots-\end{array}$ & $\begin{array}{r}2 \\
8 \\
28\end{array}$ & $\begin{array}{r}\cdots \\
5 \\
20\end{array}$ \\
\hline Tolal birds per 100 acres & 203 & 1,612 & 780 & 860 & 317 & 1,616 & $1,+51$ \\
\hline Number of species & 6 & 6 & $1+$ & 16 & $1+$ & 34 & 26 \\
\hline
\end{tabular}


Table 54.-Winter avifauna in Illinois forests (birds per 100 acres) as determined by strip censuses in the three zones. Figures in parentheses indicate numbers of acres censused; + indicates less than 1 bird per 100 acres.

\begin{tabular}{|c|c|c|c|c|c|c|c|c|c|}
\hline \multirow[b]{2}{*}{ SPECIES } & \multicolumn{3}{|c|}{ Northern ZONE } & \multicolumn{3}{|c|}{ Central Zone } & \multicolumn{3}{|c|}{ SOUTHERN ZONE } \\
\hline & $\begin{array}{c}1906-07 \\
(65)\end{array}$ & $\begin{array}{c}1956-57 \\
(24)\end{array}$ & $\begin{array}{c}1957-58 \\
(21)\end{array}$ & $\begin{array}{c}1906-07 \\
(50)\end{array}$ & $\begin{array}{c}1956-57 \\
(66)\end{array}$ & $\begin{array}{c}1957-58 \\
(86)\end{array}$ & $\begin{array}{c}1906-07 \\
(2+1)\end{array}$ & $\begin{array}{c}1956-57 \\
(120)\end{array}$ & $\begin{array}{c}1957-58 \\
(91)\end{array}$ \\
\hline Slate-colored junco... & & 96 & 24 & & $1+$ & 52 & 68 & 35 & 129 \\
\hline Tree sparrow & 6 & 92 & & 59 & 157 & 3 & 9 & 2 & \\
\hline American goldfinch & & 21 & 97 & t+ & 1 & 3 & + & 7 & \\
\hline Common crow & 12 & 17 & & 8 & 81 & 7 & 5 & 3 & 8 \\
\hline Chickadee (species?) & 9 & 8 & 44 & 6 & 9 & 12 & 15 & 18 & 18 \\
\hline Cardinal & & 8 & & 6 & $1+$ & 13 & 10 & 27 & 37 \\
\hline Blue jay & 1 & & 19 & 2 & 23 & 8 & 29 & 7 & 18 \\
\hline Tufted titmouse & $\ldots$ & + & 5 & 2 & 11 & 16 & $2+$ & 20 & 11 \\
\hline Bobwhite & & & & & 18 & & 10 & 12 & 25 \\
\hline Red-bellied woodpecker & 1 & 4 & 15 & 2 & + & 10 & 5 & 12 & 7 \\
\hline Downy woodpecker & 9 & + & 10 & 2 & 1 & t & 3 & 7 & 11 \\
\hline White-breasted nuthatch & 3 & + & 10 & 16 & & 5 & 2 & 2 & 2 \\
\hline Song sparrow & . & $\ldots$ & 15 & & 6 & 1 & 2 & 1 & 12 \\
\hline Carolina wren & 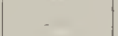 & .... & 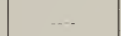 & $\ldots$ & & 5 & + & 13 & 7 \\
\hline White-throated sparrow & & .... & & .... & & & 7 & ... & 20 \\
\hline House sparrow & & 21 & & $\ldots$ & 1 & 2 & & 2 & \\
\hline Canada goose & $\cdots$ & ... & & .... & & & & & 26 \\
\hline Starling & & $\ldots$. & $\ldots .$. & .... & 1 & $\cdots$ & & $2+$ & \\
\hline Robin & $\ldots$ & ... & .... & .... & 1 & ... & 1 & 12 & 10 \\
\hline Eastern bluebird. & .... & .... & ... & .... & & .. & 15 & 9 & -.-- \\
\hline Turkey vulture & & & & & & & $2+$ & & \\
\hline Red-headed woodpecker & & & & & 3 & 1 & 1 & 2 & 15 \\
\hline Hairy woodpecker & 3 & ...- & .... & 2 & 6 & 3 & 3 & 2 & -..- \\
\hline Mourning dove & & 4 & $\ldots$. & $\ldots$ & 1 & & & $1+$ & \\
\hline Yellow-shafted flicker & $\ldots$ & .... & .... & ... & & 1 & 2 & 2 & 7 \\
\hline $\begin{array}{l}\text { Red-tailed hawk } \\
\text { Mallard }\end{array}$ & $\cdots$ & + & $\cdots$ & $\cdots$. & . & ... & $\ldots$. & 1 & $\begin{array}{l}4 \\
9\end{array}$ \\
\hline Purple finch & & 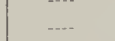 & & & & 3 & 5 & $\cdots$ & \\
\hline Rufous-sided towhee & ... & .... & ... & $\ldots$ & -... & .... & 3 & 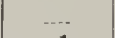 & 3 \\
\hline Yellow-bellied sapsucker & $\ldots$ & .... & ..... & -..- & -. & .... & $\ldots$ & 1 & + \\
\hline Swamp sparrow & 1 & $\ldots$ & … & & & & & 1 & 1 \\
\hline $\begin{array}{l}\text { Long-eared owl } \\
\text { Myrtle warbler }\end{array}$ & $\cdots$ & $-\cdots-$ & $\cdots$ & 2 & $\cdots$ & $\cdots$ & + & & 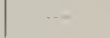 \\
\hline $\begin{array}{l}\text { Myrtle warbler } \\
\text { Red-shouldered hawk }\end{array}$ & $\cdots$ & $\cdots$. & $\cdots$ & $\cdots$ & $\cdots \cdot$ & … & + & $\begin{array}{l}2 \\
1\end{array}$ & \\
\hline $\begin{array}{l}\text { Bewn creeper } \\
\text { Browawk }\end{array}$ & & $\cdots$ & & & $\ldots$ & $\ldots$ & 1 & & 1 \\
\hline Field sparrow & $\cdots$ & $\ldots$ & -.. & $\cdots$ & -..- & $\cdots$ & 1 & 1 & \\
\hline $\begin{array}{l}\text { Winter wren } \\
\text { Mockingbird }\end{array}$ & .... & .... & .... & .... & .... & $\cdots$ & - & 2 & \\
\hline Mockingbird & $\ldots$ & ...- & .... & ...- & $\cdots$ & $\cdots-\cdot$ & & . & 2 \\
\hline $\begin{array}{l}\text { Sparrow hawk } \\
\text { Great horned owl }\end{array}$ & --.- & --- & .... & $\cdots-\cdot$ & $\cdots$ & $\cdots$. & 1 & & \\
\hline Great horned owl & -... & --- & & -... & $\cdots$ & & & 1 & \\
\hline Belted kingfisher & .... & $\ldots-$. & $\ldots$. & .... & -..- & .. & & $\cdots$ & 1 \\
\hline Pileated woodpecker & -..- & -... & $\cdots$ & --- & $\cdots$ & $\ldots$ & 1 & ...- & \\
\hline $\begin{array}{l}\text { Hermit thrush } \\
\text { Golden-crowned kinglet }\end{array}$ & .... & .... & $\cdots$ & -..- & ...- & & & ...- & 1 \\
\hline $\begin{array}{l}\text { Golden-crowned kinglet } \\
\text { Meadowlark (species?) }\end{array}$ & $\cdots \cdot$ & $\cdots-$ & - & $\ldots .-$ & $\cdots-$ & 1 & $\cdots$ & 1 & . \\
\hline $\begin{array}{l}\text { Meadowlark (species?) } \\
\text { Redwinged blackbird }\end{array}$ & $\cdots$ & $\cdots$ & $\cdots$ & $\ldots$ & $\ldots$ & $\ldots$ & - & 1 & \\
\hline Fox sparrow & & .... & .... & .... & $\ldots$. & $\ldots .$. & & 1 & \\
\hline Golden eagle & & -..- & .... & -..- & .... & $\ldots$ & + & $\ldots$ & . \\
\hline Hawk (species?) & & $\ldots$ & .... & .... & -.... & ... & 3 & - & \\
\hline Dendrocopos (species?) & $\cdots$ & $\ldots$ & .... & -...- & -... & & & 1 & \\
\hline Unidentified bird & & & & & & 2 & & 8 & 5 \\
\hline Total birds per 100 acres & 75 & 287 & 239 & 151 & 352 & 155 & 257 & 255 & 397 \\
\hline Number of species & 9 & 13 & 9 & 12 & 18 & 19 & 32 & 33 & 26 \\
\hline
\end{tabular}


less clearly defined in winter than in summer.

Number of Birds.-Because winter bird populations in nonwoody habitats are generally very sparse in northern latitudes and high in southern latitudes, it is somewhat misleading to discuss average winter bird populations for Illinois as a whole, but for comparative purposes it is convenient to use a single figure to represent each habitat in the state. Mean density figures for winter bird populations in various habitats in the northern, central, and southern zones of Illinois are presented in figs. 25-27.

Average populations for the state, as shown by surveys in January, 1957 and 1958, were 54 birds per 100 acres in winter wheat, 63 in hayfields, 82 in pastures, 85 in plowed ground, 113 in small grain stubble, 135 in soybean stubble, 153 in mechanically picked corn, 206 in fallow fields, 289 in forest, and 1,325 in shrubbery. To a very great degree, the Illinois avifauna depends on woody habitats. Still, the open habitats are probably being increasingly occupied by birds. For example, cornfields had an average January population of 48 birds per 100 acres in 1907 (stubble fields) and 153 in 1957 (mechanically picked fields).

Number of Species.-The variety of Illinois bird life in winter habitats tended to parallel the population densities in these habitats, but, more directly, it probably reflected the complexity of the habitats. Plowed ground had the fewest species of birds (9), and soybean stubble, with only slightly more cover, had 13 species in the acreage censused, followed by winter wheat and hayfields (each 23) and small grain stubble (26). Handpicked cornfields had 26 species and corn stubble or mechanically picked fields had 29 (this large number of species reflects, in part, the large acreage covered). Notably more varied were the avifaunas in pastures (32 species recorded), fallow fields (3t), shrub areas, including edge $(42)$, and forest $(48)$, tables $4+-5+$.

\section{Statewide Winter Populations}

In summer, row crops and plowed ground (habitats that are characterized by large areas of bare ground) occupy more Illinois land than any other types of habitat. In winter, because of fall plowing, these habitats are even more extensive than in summer.

In the winter of 1906-07, there were $12,398,000$ acres of row-crop stalks and stubble (corn, 10,500,000; garden vegetables, 287,000 acres) and 1,611,000 acres of plowed ground, with a population of about 9,018,000 birds. About 504,000 ( 5 per cent) of these were horned larks, most of which were concentrated on plowed ground. By the winter of 195657 , there were $15,053,000$ acres of rowcrop stubble (corn, 8,939,000 acres; garden vegetables, 75,000 acres; soybeans, 4,785,000 acres) and $1,253,000$ acres of plowed ground, with a state bird population estimated at about $21,448,000$, of which about $7,502,000$ ( 35 per cent) were horned larks.

In all census winters, birds in these row-crop or plowed-ground habitats tended to be concentrated in the central and southern zones. This concentration was particularly noticeable in the winter of 1906-07, when only about 217,000 birds were in cornfields of the northern zone, while $6,145,000$ birds ( 76 per cent of the statewide cornfield population) were in cornfields of the southern zone. By contrast, in 1956-57, about $1,339,000$ birds $(1957-58,1,877,000)$ were in cornfields of the northern zone and 5,118,000 ( 43 per cent of the statewide cornfield population) were in cornfields of the southern zone. The data suggest that birds of the Middle West were wintering farther north in 1956-1958 than in 1906-07, but to a large extent the data reflect a marked increase in the number of horned larks. Both the horned lark and Lapland longspur favor the row-crop or plowed-ground habitats, and both are hardy species that survive well in northern latitudes. Paradoxically, while plowed ground and row crops were the poorest of the summer habitats (in terms of population density), they comprised some of the best of the nonwoody habitats in winter. Bird populations in these habitats increased, partly from an expansion of the habitat and partly from an increase in population density of certain species. This situation is a prime example of man inadvertently cultivating a habitat for a particular species (in this case, the horned lark). 
In the winter of $1906-07$, there were estimated to be $2,789,000$ acres of small grain stubble in the state, with a bird population numbering about $2,078,000$. In the winter of $1956-57$, there were about $2,4+0,000$ acres of small grain stubble, with a bird population estimated at 2,129 ,000 . While small grain stubble is a good habitat for winter, most of this habitat is in the northern half of the state, and the bird species (meadowlarks and various native sparrows) that make use of such cover have a more southern distribution, while the northern-ranging species (horned lark and Lapland longspur) tend to avoid tall, dense cover.

In winter wheat, a consistently poor winter habitat, the 1906-07 avian population was estimated to be only about +55 ,000 birds on the $2,325,000$ acres of this habitat in Illinois. In 1956-57, there were about $1,004,000$ birds on the $1,639,000$ acres of winter wheat in the state and, in $1957-58$, only 486,000 birds on $1,787,000$ acres.

Pasture, which is a rich summer habitat, had surprisingly low bird populations in winter. In the winter of 1906-07, on about $6,085,000$ acres of pastureland, there were about $+, 936,000$ birds. Reduction in pasture acreage (to 2,004,000 acres) brought the winter bird population in this habitat down to about 2,000,000 (1,761,000 in $1956-57$ and $2,199,000$ in $1957-$ $58)$.

The acreage of fallow fields in winter was reduced from about 1,+96,000 acres in $1906-07$ to about $1,03+, 000$ acres in 1956-57, but, because of an increase in population density, the statewide winter bird population in this habitat was estimated to be higher in 1956-57 (2,618,$000)$ and $1957-58(2,114,000)$ than in 1906-07 (1,266,000).

Hayfields in the winter of 1906-07 had a population estimated at only $1,+60,000$ birds on 3,2+5,000 acres. With increased acreage (to $5,25+, 000$ acres), the population was estimated to be $3,601,000$ birds in the winter of 1956-57.

The woody habitats (shrub and forest) had very high bird populations in winter as in summer. In the winter of 1906-07, $+69,000$ acres of shrub-grown land had an estimated population of $1,+22,000$ birds. Though there was little change in acre- age by $1956-57$ ( 507,000 acres), the population in this habitat was about $7,210,000$ birds; the 1957-58 population was nearly as high $(6,433,000$ birds). Several species of birds were represented in this apparent increase between the winters of 1906-07 and 1956-57. The change may be further evidence that birds in the Middle West tended to winter farther north in 19561958 than in 1906-07.

Forest acreage increased from about 3,$+59,000$ acres in $1906-07$ to $3,996,000$ acres in 1956-1958. The winter bird population in forest increased far out of proportion to the acreage change, from about $6,654,000$ birds in $1906-07$ to about 11 ,079,000 in 1956-57, and the 1957-58 population was even higher (approximately 12,985,000 birds).

In all of these types of winter habitats censused in Illinois, there was a population estimated at $27,289,000$ birds on 32 ,267,000 acres in $1906-07$ and $50,851,000$ birds on $31,927,000$ acres in 1956-57. Even the lower population in 1957-58 (approximately $47,492,000$ birds on 31 ,$+83,000$ acres) was well above the 190607 level.

The difference in winter bird populations between 1906-07 and 1956-1958 cannot be explained solely as annual variation. There are probably at least two major causes of the increase: (1) actual population increases in a few species, such as the horned lark, and (2) changes in winter distribution of several species, with many birds of the Middle West wintering farther north in 1956-1958 than in 190607.

Much of the Illinois winter bird population was in the southern zone of the state. This zone, as we have defined it, includes about $15,9+7,000$ acres of land ( +4.5 per cent of the state), which contained about $18,000,000$ birds (65 per cent of the state population) in 1906-07, about $30,000,000$ birds ( 60 per cent) in 1956-57, and about $32,000,000$ birds (67 per cent) in 1957-58. 'The northern zone $(8,778,000$ acres of land or 24.5 per cent of the state acreage) had winter populations estimated to total $3,500,000$ birds (13 per cent of the state population) in 1906-07, 5,38+,000 birds (11 per cent) in 1956-57, and 5,157,000 birds (11 per cent) in 1957-58. 
The quantitative distribution of birds in the state in winter can best be observed in the mean density figures for each zone. Mean population densities (calculated number of birds in an area divided by the number of acres in the area) for all nonurban habitats in the three zones of the state in January, 1907, were 0.5 in the northern zone ( 0.7 in 1957$), 0.7$ in the central (1.6 in 1957), and 1.3 in the southern (2.1 in 1957). (Bird populations in urban areas and urban acreage were not included in the calculation of the mean densities because we lacked winter data for this habitat.) The density of the winter population of birds in nonurban Illinois habitats increased between 1907 and 1957; the increase in the northern zone (about 41 per cent increase above the 1907 level) lagged behind that in the southern zone (about 64 per cent increase above the 1907 level).

It should be noted here that there is a limit to the number of birds that can survive on a given land area in a particular climate. 'The January, 1907, population was presumably closer to saturation level in the northern zone of Illinois than in the southern zone. This saturation level may vary somewhat from year to year, but it is set within definite limits by climate, soil, land use, and other factors. How much more the winter population of Illinois birds may increase with the existing climate and agricultural situation cannot be predicted; additional points of reference on this problem would be extremely interesting. Some additional impression of the influence of winter climate on bird distribution may be obtained by comparing summer densities with winter densities in the three zones, fig. 28 .

In view of the mass migration of species from the state following the nesting season, the winter population of birds, when compared with the summer population, was surprisingly high. We estimated that in the winter of 1906-07 the population was about $30,936,000$ birds on approximately $34,917,000$ acres (total land area of Illinois less urban and road-surface areas). This acreage included some types of habitats not censused (such as home gardens, airports, and cemeteries) and is therefore greater than the acreage for the census figures on page 457 . The estimated

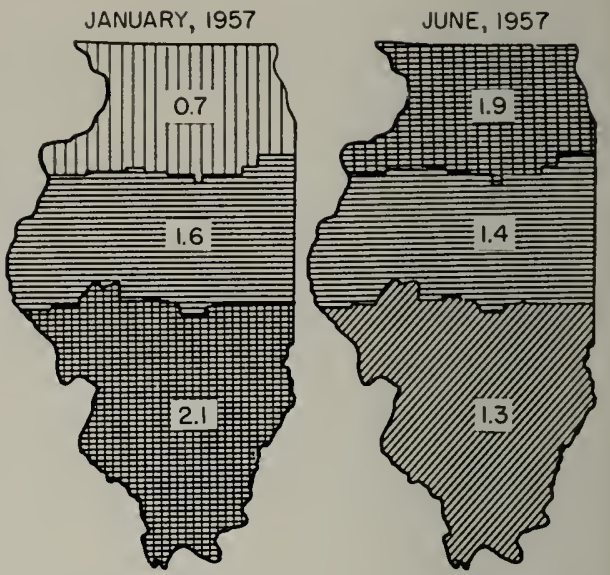

Fig. 28.-Distribution of bird populations in Illinois in winter and summer. Hatching represents density of the bird population in each of the three zones of the state. The numerals in each zone represent the mean number of birds per acre for all nonurban habitats censused in the zone in January or June, 1957.

population on the same acreage in the summer of 1909 was 56,949,000 birds. We estimated that in the winter of 1956-57 the population was about $5 t, 111,000$ birds on approximately $33,672,000$ acres (total land area of Illinois less urban and road-surface acreage). The estimated population on the same acreage in the following summer (1957) was $49,464,000$. Thus, the winter population in some years may exceed the summer level. The size of the winter populations was particularly impressive in view of the fact that most Illinois birds in winter were in the southern half of the state, fig. 28.

\section{ACCOUNT OF SPECIES}

In four summer seasons (1907, 1909, 1957, and 1958) and three winters (1906-07, 1956-57, and 1957-58) in Illinois, 168 species of birds were identified in census strips. Nine additional species were identified outside the census strips. The census method was not intended to provide complete qualitative data on the avifauna of Illinois, but the list of species recorded, table 55, includes most of the species that winter or breed in terrestrial habitats of the state.

Smith \& Parmalee (1955) included 38+ species in their check list of Illinois birds. Ninety-one of these are extinct or of only 
Table 55.-Species of birds encountered in strip censuses in the three zones of Illinois; $x$ indicates a species recorded within one or more of the census strips; $*$ indicates a species recorded in the zone indicated but outside one of the census strips.

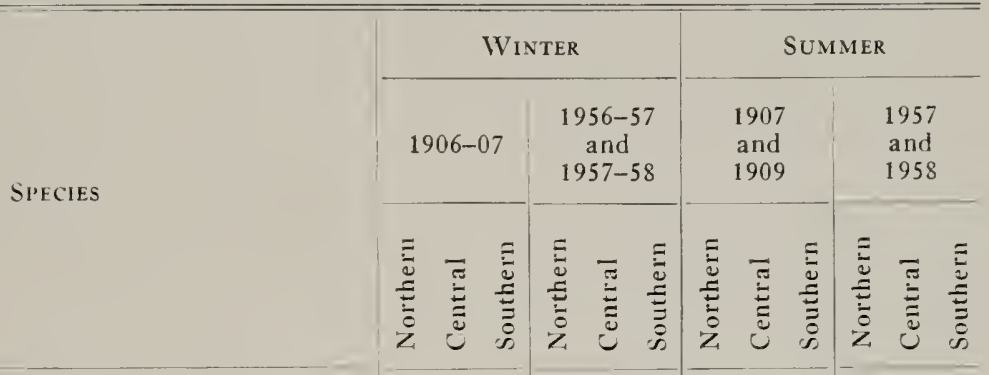

Horned grebe, Podiccps auritus.

Great blue heron, Ardea herodias

Green heron, Butorides virescens

Little blue heron, Florida caerulea

Common egret, Casmerodius albus.

Black-crowned night heron, Nycticorax nycticorax Least bittern, Ixobrychus exilis.

American bittern, Botaurus lentiginosus

Canada goose, Branta canadensis.

Blue goose, Chen caerulescens.

Mallard, Anas platyrhynchos.

Black duck, Anas rubripes.

Blue-winged teal, Anas discors

Wood duck, Aix sponsa

Lesser scaup, Aythya affinis

Turkey vulture, Cathartes anra.

Black vulture, Coragyps atratus

Cooper's hawk, Accipiter cooperii

Red-tailed hawk, Butco jamaicensis.

Red-shouldered hawk, Butco lineatus.

Broad-winged hawk, Buteo platypterus

Rough-legged hawk, Buteo lagopus.

Golden eagle, Aquila chrysaetos

Bald eagle, Haliaectus leucocephalus

Marsh hawk, Circus cyancus.

Sparrow hawk, Falco sparverius

Greater prairie chicken, Tympanuchus cupido

Bobwhite, Colinus virginianus

Ring-necked pheasant, Phasianus colchicus

Gray partridge, Perdix perdix.

King rail, Rallus elcgans

Virginia rail, Rallns limicola

Sora, Porzana carolina

Common gallinule, Gallinula chloropus

American coot, Fulica americana

Killdeer, Charadrius vociferus

American woodcock, Philohela minor

Common snipe, Capella gallinago

Upland plover, Bartramia longicauda

Spotted sandpiper, Actitis macularia

Herring gull, Larus argentatus

Ring-billed gull, Larus delawarensis

Black tern, Chlidonias niger

Rock dove, Columba livia

Mourning dove, Zcnaidura macroura

Yellow-billed cuckoo, Coccyzus americanus

Black-billed cuckoo, Coccyzus erythropthalmus

Great horned owl, Bubo virginianus

Barred owl, Strix varia

Long-eared owl, Asio otus 
Table 55.-Continued

\begin{tabular}{|c|c|c|c|c|c|c|c|c|c|c|c|c|}
\hline \multirow{3}{*}{ SPECIES } & \multicolumn{6}{|c|}{ WINTER } & \multicolumn{6}{|c|}{ SUMMER } \\
\hline & \multicolumn{3}{|c|}{$1906-07$} & \multicolumn{3}{|c|}{$\begin{array}{c}1956-57 \\
\text { and } \\
1957-58\end{array}$} & \multicolumn{3}{|c|}{$\begin{array}{l}1907 \\
\text { and } \\
1909\end{array}$} & \multicolumn{3}{|c|}{$\begin{array}{l}1957 \\
\text { and } \\
1958\end{array}$} \\
\hline & 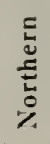 & 苞 & 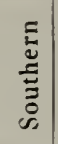 & 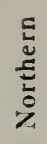 & 苟 & & 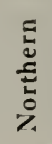 & שٓ & 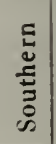 & 吉 & U్ & 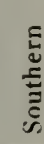 \\
\hline $\begin{array}{l}\text { lort-eared owl, Asio flammeus. } \\
\text { ww-whet owl, Acgolius acadicus. }\end{array}$ & - & -- & -- & & $\mathrm{x}$ & $\mathrm{x}$ & .- & -. & -- & - & - & \\
\hline $\begin{array}{l}\text { Saw-whet owl, Acgolius acadicus. } \\
\text { Whip-poor-will, Caprimulgus vociferus }\end{array}$ & $\ddot{-}$ & $\ddot{-}$ & - & & x & &.- & - & - & - & - & $\bar{x}$ \\
\hline Common nighthawk, Chordeiles minor & -- & - & - & $\ddot{-}$ & - & $\ddot{-}$ & & $\bar{x}$ & $\bar{x}$ & * & * & \\
\hline Chimney swift, Chactura pclagica & & - & - & .. & .- & - & $x$ & $\mathrm{x}$ & $\mathrm{x}$ & $\mathrm{x}$ & $\mathrm{x}$ & \\
\hline $\begin{array}{l}\text { Ruby-throated hummingbird, Archilochus colubris } \\
\text { Belted kingfisher, Megaceryle alcyon }\end{array}$ & -. & - & * & -. & - & $\bar{x}$ & & $\begin{array}{l}\mathbf{x} \\
\mathbf{x}\end{array}$ & $\begin{array}{l}x \\
x\end{array}$ & $\begin{array}{l}\mathrm{x} \\
\mathrm{x}\end{array}$ & $\begin{array}{l}x \\
x\end{array}$ & * \\
\hline Vellow-shafted flicker, Colaptes auratus & $x$ & $\mathrm{x}$ & $\mathbf{x}$ & $\mathrm{x}$ & $\mathrm{x}$ & $\mathrm{x}$ & $\mathrm{x}$ & $\mathrm{x}$ & $\mathbf{x}$ & $x$ & $\mathbf{x}$ & \\
\hline Pileated woodpecker, Dryocopus pileat & .- & -. & - & & & * & -- & & & & & \\
\hline Red-bellied woodpecker, Crnturus caro & $\mathrm{x}$ & $\mathrm{x}$ & $\mathrm{x}$ & $\mathrm{x}$ & $\mathbf{x}$ & $\mathbf{x}$ & & & $\mathbf{x}$ & * & $x$ & $\mathrm{x}$ \\
\hline $\begin{array}{l}\text { Red-headed woodpecker, Melanerpes } \\
\text { erythrocephalus }\end{array}$ & & & $\mathbf{x}$ & & $\mathrm{x}$ & $\mathbf{x}$ & $\mathrm{x}$ & $\mathrm{x}$ & $\mathbf{x}$ & $\mathrm{x}$ & $\mathbf{x}$ & $\mathbf{x}$ \\
\hline $\begin{array}{l}\text { Vellow-bellied sapsucker, sphyrapicus varius } \\
\text { Hairy woodpecker, Dendrocopos villosus }\end{array}$ & - & $\bar{x}$ & -. & & & $\mathrm{x}$ & .. & $\ddot{\mathrm{x}}$ & $\ddot{x}$ & * & $\bar{x}$ & \\
\hline $\begin{array}{l}\text { Hairy woodpecker, Dendrocopos villos } \\
\text { Downy woodpecker, Dendrocopos pult, }\end{array}$ & $\begin{array}{l}x \\
x\end{array}$ & $\mathrm{x}$ & $\begin{array}{c}x \\
x\end{array}$ & $\mathrm{x}$ & $\begin{array}{l}x \\
x\end{array}$ & $\mathbf{x}$ & * & * & $\mathbf{x}$ & $\mathbf{x}$ & $\mathrm{x}$ & \\
\hline Eastern kingbird, Tyrannus tyrannus & & - & _- & _- & .- & .- & $\mathrm{x}$ & $\mathrm{x}$ & $\mathbf{x}$ & $\mathbf{x}$ & $\mathbf{x}$ & $\mathbf{x}$ \\
\hline Great crested fycatcher, Myiarchus crinitus & - & - & - & - & - & - & * & $x$ & $x$ & $x$ & $\begin{array}{l}\mathbf{x} \\
*\end{array}$ & $x$ \\
\hline Yellow-bellied flycatcher, Empidonax flaviventris & - & - & - & $\overline{-}-$ & $\overline{-}$ & $\begin{array}{l}-- \\
-\end{array}$ & & $\begin{array}{l}\mathrm{x} \\
\mathrm{x}\end{array}$ & & $\begin{array}{l}\mathbf{x} \\
--\end{array}$ & & \\
\hline Acadian fycatcher, Em pidonax rirescens & - & - & - & -- & .- & -. & & & $\mathbf{x}$ & $\bar{x}$ & $\ddot{x}$ & \\
\hline Traill's flycatcher, Empidonax traillii & & -. & - & .- & .- & _. & & $\mathbf{x}$ & $\mathbf{x}$ & $\mathbf{x}$ & $\mathbf{x}$ & $x$ \\
\hline Least flyc & .- & .. & - & -. & -- & -. & & $\mathbf{x}$ & & .- & .. & \\
\hline Eastern wood pewee, Contopus virens & - & - & - & -. & - & -- & $\mathbf{x}$ & * & $\mathbf{x}$ & $\mathrm{x}$ & $x$ & \\
\hline Horned lark, Eremophila alpestris & $\mathrm{x}$ & $x$ & $x$ & $\mathrm{x}$ & $x$ & $\mathbf{x}$ & $x$ & $\mathrm{x}$ & $\mathbf{x}$ & $\mathrm{x}$ & $x$ & $\mathrm{x}$ \\
\hline llow, Iridoprocue bicolor & .. & .. & - & .- & .. & -- & .. & -. & - & $\mathbf{x}$ & $\mathrm{x}$ & \\
\hline llow, Riparia riparia & & - & - & & .. & - & $\mathrm{x}$ & $\mathrm{x}$ & & $x$ & $x$ & \\
\hline tclgidopteryx ruficollis. & -. & -. & - & -. & -- & -. & & & .. & $x$ & $\mathbf{x}$ & $\mathrm{x}$ \\
\hline Barn s & .. & .. & .- & .- & -- & -- & $\mathrm{x}$ & $x$ & $x$ & $\mathrm{x}$ & $x$ & $\mathbf{x}$ \\
\hline Cliff swallow, Petrochelidon pyrrhonota & -. & - & - & - & -. & -- & & $\mathbf{x}$ & $\mathbf{x}$ & $\mathrm{x}$ & & \\
\hline Purple martin, Progne subis & -- & -- & -- & .- & .- & .. & & $\mathrm{x}$ & $\mathbf{x}$ & $\mathrm{x}$ & $\mathrm{x}$ & $\mathrm{x}$ \\
\hline Blue jay, Cyanocitta crista & $x$ & $\mathrm{x}$ & $\bar{x}$ & $\mathrm{x}$ & $\bar{x}$ & $\bar{x}$ & $\mathrm{x}$ & $\mathrm{x}$ & $\mathbf{x}$ & $\mathrm{x}$ & $x$ & $\mathbf{x}$ \\
\hline Common crow, Corvus brachyrliynchos & $x$ & $x$ & $\mathrm{x}$ & $\mathrm{x}$ & $\mathrm{x}$ & $\mathrm{x}$ & $x$ & $\mathrm{x}$ & $\mathrm{x}$ & $x$ & $x$ & $x$ \\
\hline & $\mathrm{x}$ & $\mathrm{x}$ & $\mathrm{x}$ & $x$ & $\mathrm{x}$ & $\mathrm{x}$ & $*$ & * & $x$ & $\mathbf{x}$ & $x$ & $\mathrm{x}$ \\
\hline $\begin{array}{l}\text { Black-capped chickadee, Parus atricapillus } \\
\text { Carolina chichadee Parus }\end{array}$ & $\mathbf{x}$ & $\mathrm{x}$ & $\mathrm{x}$ & & & & .. & * & -. & $\mathbf{x}$ & & \\
\hline $\begin{array}{l}\text { Carolina chichadee, Parus carolinensis } \\
\text { Tufted titmouse, Parus licolor }\end{array}$ & & $\begin{array}{l}x \\
x\end{array}$ & $\begin{array}{l}x \\
x\end{array}$ & $\mathrm{x}$ & $\mathrm{x}$ & $\begin{array}{l}x \\
x\end{array}$ & & * & $\begin{array}{l}x \\
x\end{array}$ & & $\begin{array}{l}x \\
x\end{array}$ & $\begin{array}{l}\mathbf{x} \\
\mathbf{x}\end{array}$ \\
\hline White-breasted nuthatch, Sitta carolinensis & $\mathrm{x}$ & $\mathbf{x}$ & $x$ & $\mathrm{x}$ & $\mathrm{x}$ & $\mathbf{x}$ & & $\mathrm{x}$ & & $x$ & $x$ & $x$ \\
\hline $\begin{array}{l}\text { Brown creeper, Corlhia familiaris } \\
\text { House wren, Troolodytes acdon }\end{array}$ & $\mathrm{x}$ & & $\mathrm{x}$ & & & $x$ & & & & & & \\
\hline Winter wren, Troglodytes troglodytes & $\because$ & & 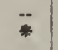 & - & & $\bar{x}$ & .. & $\mathbf{x}$ & $\begin{array}{c}\mathrm{x} \\
--\end{array}$ & $\mathrm{x}$ & $\begin{array}{c}\mathbf{x} \\
-.\end{array}$ & \\
\hline Bewick's wren, Thryomanes licwickii & & & & -- & -- & & & $*$ & $\mathbf{x}$ & & & \\
\hline Carolina wren, Thryothorus ludovicianus & * & & $x$ & & $\mathbf{x}$ & $\mathbf{x}$ & & & $\mathbf{x}$ & & $x$ & $x$ \\
\hline 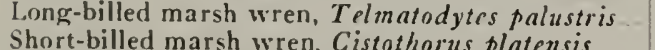 & .- & -. & -- & & $\mathbf{x}$ & $\mathbf{x}$ & .. & .. & .. & $\mathrm{x}$ & & \\
\hline $\begin{array}{l}\text { Short-billed marsh wren, Cistothorus platensis. } \\
\text { Mockingbird, Mimus polyglottos }\end{array}$ & & & $\ddot{x}$ & .- & -- & & & & $\ddot{x}$ & $x$ & * & \\
\hline umetclla carolinensis. & & & & - & - & $x$ & $\mathrm{x}$ & $\mathrm{x}$ & $\mathrm{x}$ & $\mathrm{x}$ & $\mathrm{x}$ & $\mathbf{x}$ \\
\hline Brown thrasher, Toxostoma rufum & & & -- & - & & - & $\mathrm{x}$ & $\mathbf{x}$ & $\mathbf{x}$ & $\mathbf{x}$ & $\mathbf{x}$ & $x$ \\
\hline & * & & $\mathbf{x}$ & & $x$ & $\mathbf{x}$ & $\mathrm{x}$ & $\mathbf{x}$ & $\mathbf{x}$ & $\mathrm{x}$ & $\mathbf{x}$ & $\mathbf{x}$ \\
\hline Wood thrush, Hylocichla mustelina & - & -- & -- & -- & - & - & & * & $x$ & $\mathrm{x}$ & $x$ & $\mathbf{x}$ \\
\hline Hermit thrush, Hylocichla guttata & - & .- & - & & & $\mathbf{x}$ & -- & -- & -. & -. & -- & -- \\
\hline Swainson's thrush, Hylocichlo ustulata & - & - & - & - & -. & .- & & $\mathbf{x}$ & & .- & -- & - \\
\hline
\end{tabular}


Table 55.-Continued

\begin{tabular}{|c|c|c|c|c|c|c|c|c|c|c|c|c|}
\hline \multirow{3}{*}{ SPECIES } & \multicolumn{6}{|c|}{ Winter } & \multicolumn{6}{|c|}{ SUMMER } \\
\hline & \multicolumn{3}{|c|}{$1906-07$} & \multicolumn{3}{|c|}{$\begin{array}{l}1956-57 \\
\text { and } \\
1957-58\end{array}$} & \multicolumn{3}{|c|}{$\begin{array}{c}1907 \\
\text { and } \\
1909\end{array}$} & \multicolumn{3}{|c|}{$\begin{array}{l}1957 \\
\text { and } \\
1958\end{array}$} \\
\hline & 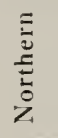 & 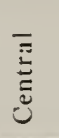 & 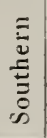 & 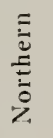 & 矛 & 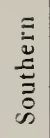 & 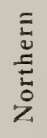 & 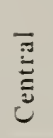 & 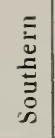 & 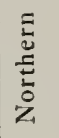 & $\underset{\tilde{\Xi}}{\bar{\Xi}}$ & 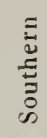 \\
\hline Eastern bluebird, Sialia sialis & $\mathrm{x}$ & & $\mathrm{x}$ & & $\mathrm{x}$ & $\mathrm{x}$ & $\mathrm{x}$ & $\mathrm{x}$ & $\mathrm{x}$ & $\mathrm{x}$ & $\mathrm{x}$ & $\mathrm{x}$ \\
\hline Blue-gray gnatcatcher, Polioptila & .- & & & -- & -- & - & -- & .- & - & $\mathrm{x}$ & $\mathrm{x}$ & $\mathrm{x}$ \\
\hline Golden-crowned kinglet, Regulus satraf & & & * & & $\mathrm{x}$ & & -- & -. & .. & - & - & - \\
\hline by-crowned kinglet, Regulus calendu & -. & -- & & & & $\mathrm{x}$ & - & -. & .- & - & - & - \\
\hline Vater pipit, Anthus spinoletta & & -- & - & & & $x$ & -- & -. & -- & - & - & - \\
\hline Sprague's pipit, Anthus spragucii & -- & -. & -- & & & $\mathrm{x}$ & -- & -. & - & & - & - \\
\hline edar waxwing, Bombycilla cedror & -- & -- & -- & & $\mathrm{x}$ & $\mathrm{x}$ & -- & -- & .- & * & & \\
\hline Northern shrike, Lanins excubitor & & - & -- & & * & & $-\bar{\gamma}$ & $\therefore$ & $\ddot{x}$ & $-\bar{x}$ & - & $\bar{x}$ \\
\hline Loggerhead shrike, Lanius ludovicianus & & & $\mathrm{x}$ & & * & $\mathrm{x}$ & $x$ & $\mathrm{x}$ & $\mathrm{x}$ & $\mathrm{x}$ & $\mathrm{x}$ & $x$ \\
\hline Starling, Sturnus v'ulgaris & -. & -- & -- & $\mathrm{x}$ & $\mathrm{x}$ & $\mathrm{x}$ & -. & -. & & $\mathrm{x}$ & $x$ & \\
\hline $\begin{array}{l}\text { White-eyed vireo, rireo griseus } \\
\text { Bell's vireo, Viren bellii }\end{array}$ & -. & - & -. & -- & - & -- & & & $\mathrm{x}$ & & & $\mathrm{x}$ \\
\hline $\begin{array}{l}\text { ell's vireo, l'iren bellii } \\
\text { ellow-throated vireo, liven favifrons }\end{array}$ & - & - & -- & -- & -- & -- & & -- & -- & & $\mathrm{x}$ & $\begin{array}{l}x \\
x\end{array}$ \\
\hline $\begin{array}{l}\text { ellow-throated vireo, } l \\
\text { ed-eyed vireo, Vireo oli }\end{array}$ & .. & .. & -- & -- & -- & -- & & $\approx$ & $\ddot{x}$ & $\mathrm{x}$ & $x$ & $\begin{array}{c}x \\
x\end{array}$ \\
\hline $\begin{array}{l}\text { Red-eyed vireo, Vireo olizaccus } \\
\text { Warbling vireo, Vireo gilvus }\end{array}$ & - & -- & .- & -. & $\ddot{-.}$ & - & $\begin{array}{c}x \\
x\end{array}$ & $\mathrm{x}$ & $\begin{array}{l}x \\
x\end{array}$ & $x$ & $\mathrm{x}$ & $\begin{array}{l}x \\
x\end{array}$ \\
\hline $\begin{array}{l}\text { Warbling vireo, Vireo gilvus } \\
\text { Black-and-white warbler, Muiotilta war }\end{array}$ & - & - & & & & & & & $\mathrm{x}$ & $\mathrm{x}$ & $\mathrm{x}$ & $\mathrm{x}$ \\
\hline $\begin{array}{l}\text { Black-and-white wa } \\
\text { Prothonotary warbl }\end{array}$ & - & - &.- & - & -. & - & & & ${ }^{*}$ & & & $\begin{array}{l}x \\
x\end{array}$ \\
\hline $\begin{array}{l}\text { rothonotary warbber, Protonothina citrea } \\
\text { Vorm-eating warbler, Ifelmitheros vermiz }\end{array}$ & -- & & -- & -- & $\therefore$ & - & - & _- & x & & & $\begin{array}{l}\mathrm{x} \\
\mathrm{x}\end{array}$ \\
\hline $\begin{array}{l}\text { Vorm-eating warbler, Helmitheros vermiz'orus } \\
\text { wainson's warbler, Limnothlypis sciainsonii }\end{array}$ & .- & -. & - & -- & - & -. & - & - & $\bar{x}$ & _- & - & $\mathrm{x}$ \\
\hline $\begin{array}{l}\text { Swainson's warbler, Limnothlypis sicainsouli } \\
\text { Parula warbler, Parula americana }\end{array}$ & & & .- & & .. & .- & & $\mathrm{x}$ & & & & $\overline{\mathrm{x}}$ \\
\hline Yellow warbler, Dendro & -. & .. & - & .- & - & -. & $\mathrm{x}$ & & $\mathrm{x}$ & & $\mathrm{x}$ & $\mathrm{x}$ \\
\hline Magnolia wart & -. & -. & -. & .. & -- & -. & & $\mathrm{x}$ & & -. & -. & - \\
\hline Myrtle warbler, Dendro & & & $\mathrm{x}$ & & & $\mathrm{x}$ & -- & .. & .- & -- & -. & - \\
\hline Cerulean warbler, Dendroica cerulea & -. & .. & -- & -- & -. & -- & .- & -. & -- & $\mathrm{x}$ & $\mathrm{x}$ & $\mathbf{x}$ \\
\hline Yellow-throated warbler, Dendroica dominica & -. & - & - & -. & -- & - & .. & -. & - & & & * \\
\hline Chestnut-sided warbler, Dendroica pe & -- & .- & -- & -. & ... & -- & & $\mathrm{x}$ & & - & -. & - \\
\hline arbler, Dendroica disco & -- & - & - & - & - & - & -- & $\cdot-$ & $\cdot-$ & & & $\mathrm{x}$ \\
\hline $\begin{array}{l}\text { Prairie warbler, Dendroica disco } \\
\text { Palm warbler, Dendroica palmar }\end{array}$ & - & .. & $\ddot{-}$ & $\begin{array}{l}. . \\
.\end{array}$ & $\ddot{-.}$ & - & -. & $\mathrm{x}$ & & _- & 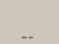 & $\mathrm{x}$ \\
\hline Ovenbird, Sciurus anrocapillus & - & -. & - & -. & .. & - & & -- & -. & $\mathrm{x}$ & $\mathrm{x}$ & \\
\hline Louisiar & & -. & - & .. & -- & -- & & & $\mathrm{x}$ & $\mathrm{x}$ & & $\mathbf{x}$ \\
\hline & .- & .- & .. & .- & .. & .- & & & & & $\mathrm{x}$ & $\mathrm{x}$ \\
\hline Yellowthroat, Geothlypis trichas & .- & .- & .. & .. & .- & .- & $\mathrm{x}$ & $\mathrm{x}$ & $\mathrm{x}$ & $\mathrm{x}$ & $\mathrm{x}$ & $\mathrm{x}$ \\
\hline & 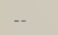 & .- & -. & .. & .. & _- & & & $\mathrm{x}$ & & $\mathrm{x}$ & $\mathrm{x}$ \\
\hline Hooded warbler, Wilsonia citrina & & -- & & -- & .- & - & -. & -- & - & & & $\mathrm{x}$ \\
\hline in redstart, Setophaga ruticilla & & & & -. & .. & .- & & $\mathrm{x}$ & $\mathrm{x}$ & $\mathrm{x}$ & $\mathrm{x}$ & $\mathrm{x}$ \\
\hline & $\mathrm{x}$ & $\mathrm{x}$ & $\mathrm{x}$ & $\mathrm{x}$ & $\mathbf{x}$ & $\mathrm{x}$ & $\mathrm{x}$ & $\mathrm{x}$ & $\mathrm{x}$ & $\mathrm{x}$ & $\mathrm{x}$ & $\mathrm{x}$ \\
\hline Bobolink, Dolichonyx oryzivorus. & & - & & .. & -. & & $\mathrm{x}$ & $\mathrm{x}$ & & $\mathrm{x}$ & $\mathrm{x}$ & \\
\hline Meadowlark, Sturnella spp. & $\mathrm{x}$ & & $\mathrm{x}$ & $\mathrm{x}$ & $\mathrm{x}$ & $\mathrm{x}$ & $\mathrm{x}$ & $\mathrm{x}$ & $\mathrm{x}$ & $\mathrm{x}$ & $\mathrm{x}$ & $\mathrm{x}$ \\
\hline Eastern meadowlark, Sturuella magna & & - & -- & & $\mathrm{x}$ & $\mathrm{x}$ & -- & - &.$\cdot$ & $\mathrm{x}$ & $\mathrm{x}$ & $\mathrm{x}$ \\
\hline $\begin{array}{l}\text { Western meadowlark, Sturnella neglecta } \\
\text { Yellow-headed blackbird, Xanthocephalus } \\
\text { xanthocephalus }\end{array}$ & -- & -. & -- & $x$ & $\mathrm{x}$ & - & .- & -- & -- & $\mathrm{x}$ & $\mathrm{x}$ & \\
\hline Redwinged blackbird, Agelaius phocniceus. & * & & & & & $\bar{x}$ & $\mathrm{x}$ & $\mathrm{x}$ & $\mathrm{x}$ & $\mathrm{x}$ & $\mathrm{x}$ & $\mathrm{x}$ \\
\hline & & .. & -- & -. & -- & - & $\mathrm{x}$ & $\mathrm{x}$ & $\mathrm{x}$ & $\mathrm{x}$ & $\mathrm{x}$ & $\mathrm{x}$ \\
\hline Baltir & & -- & & .. & .- & - & $\mathrm{x}$ & $\mathrm{x}$ & $\mathrm{x}$ & $\mathrm{x}$ & $\mathrm{x}$ & $x$ \\
\hline Rusty & & - & - & & & $\mathrm{x}$ & - & - & -. & $\ddot{x}$ & - & - \\
\hline & & -. & - & -- & -- & $\bar{x}$ & - & 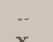 & $\ddot{z}$ & $x$ & & \\
\hline Common grackle, Quiscalus quiscula & .. & .- & - & & & $\mathrm{x}$ & $\mathrm{x}$ & $\mathrm{x}$ & $\mathrm{x}$ & $\mathrm{x}$ & $\mathrm{x}$ & $\mathrm{x}$ \\
\hline Brown-headed cowbird, Molothrus ater & -. & -- & - & & & $\mathrm{x}$ & $\mathrm{x}$ & $x$ & $\mathrm{x}$ & $\mathrm{x}$ & $\mathrm{x}$ & $x$ \\
\hline Scarlet tanager, Piranga olizacea & 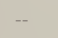 & .. & -- & -- & -- & -- & & $\mathrm{x}$ & $\mathrm{x}$ & $\mathrm{x}$ & * & $\mathrm{x}$ \\
\hline
\end{tabular}


Table 55.-Continued

Summer tanager, Piranga rubra

Cardinal, Richmondena cardinalis

Rose-breasted grosbeak, Pheucticus ludovicianus

Blue grosbeak, Guiraca caerulea

Indigo bunting, Passerina cyanea

Dickcissel, Spiza americana

Purple finch, Carpodacus purpureus

American goldfuch, Spinus tristis

Rufous-sided towhee, Pipilo erythrophthalmus...

Savannah sparrow, Passerculus sandwichensis.

Grasshopper sparrow, Ammodramus sarannarum

Le Conte's sparrow, Passerherbulus caudacutus

Henslow's sparrow, Passcrherbulus henslorvii.

Vesper sparrow, Pooecetes gramineus

Lark sparrow, Chondestes grammacus

Bachman's sparrow, Aimophila aestivalis

Slate-colored junco, Junco hyemalis.

Tree sparrow, Spizella arborea

Chipping sparrow, Spizella passerina

Field sparrow, Spizella pusilla

Harris' sparrow, Zonotrichia querula

White-crowned sparrow, Zonotrichia leucophrys

White-throated sparrow, Zonotrichia albicollis.

Fox sparrow, Passer lla iliaca

Swamp sparrow, Melospiza georgiana

Song sparrow, Melospiza melodia

Lapland longspur, Calcarius lapponicus

Smith's longspur, Calcarius pictus

Snow bunting, Plectrophenax nivalis

\begin{tabular}{|c|c|c|c|c|c|c|c|c|c|c|c|}
\hline \multicolumn{6}{|c|}{ W'INTER } & \multicolumn{6}{|c|}{ SUMMER } \\
\hline \multicolumn{3}{|c|}{$1906-07$} & \multicolumn{3}{|c|}{$\begin{array}{c}1956-57 \\
\text { and } \\
1957-58\end{array}$} & \multicolumn{3}{|c|}{$\begin{array}{l}1907 \\
\text { and } \\
1909\end{array}$} & \multicolumn{3}{|c|}{$\begin{array}{c}1957 \\
\text { and } \\
1958\end{array}$} \\
\hline 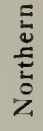 & Ј & 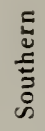 & 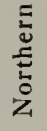 & 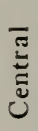 & 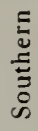 & 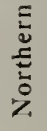 & 苞 & 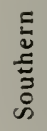 & 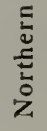 & 苞 & \\
\hline -- & - & - & - & - & - & & $*$ & $\mathbf{x}$ & & & $x$ \\
\hline & $\mathbf{x}$ & $\mathbf{x}$ & $\mathbf{x}$ & $\mathbf{x}$ & $x$ & & $x$ & $x$ & $x$ & $\mathbf{x}$ & $x$ \\
\hline -- & - & -- & - & - & - & $\mathrm{x}$ & $\mathbf{x}$ & & $\mathbf{x}$ & $\mathbf{x}$ & \\
\hline- & - & - & -- & - & - & -- & - & -- & & * & $\mathbf{x}$ \\
\hline -- &.- & - & - & -- & -- & $x$ & $x$ & $x$ & $x$ & $\mathbf{x}$ & $x$ \\
\hline -. & .- & $\ddot{x}$ & - & $\ddot{x}$ & - & $\mathrm{x}$ & $\mathbf{x}$ & $\mathrm{x}$ & $\mathrm{x}$ & $x$ & $\mathbf{x}$ \\
\hline & & $x$ & & $x$ & & $\overline{-}$ & $\overline{-}$ & $\bar{x}$ & $\vec{x}$ & $\ddot{r}$ & $\bar{r}$ \\
\hline $\mathbf{x}$ & x & $\mathbf{x}$ & $\mathbf{x}$ & $\mathbf{x}$ & $\mathbf{x}$ & $x$ & $\mathbf{x}$ & $x$ & $\mathbf{x}$ & $\mathbf{x}$ & $\mathbf{x}$ \\
\hline & & $\mathbf{x}$ & & $\mathbf{x}$ & $\mathrm{x}$ & $x$ & $\mathbf{x}$ & $\mathbf{x}$ & $x$ & $\mathbf{x}$ & $x$ \\
\hline -. & -- & - & $\mathbf{x}$ & & $\mathbf{x}$ & $x$ & $x$ & & $x$ & & \\
\hline -- & - & - & -- & - & - & $x$ & $\mathbf{x}$ & $x$ & $x$ & $x$ & $x$ \\
\hline -- & - & - & & 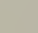 & $\mathbf{x}$ & -- & -- & - & 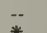 & - & - \\
\hline -- & -- & - & -- & -- & -- & & $\mathrm{x}$ & & * & $\mathbf{x}$ & \\
\hline -- & - & - & -- & -- & -. & $\mathrm{x}$ & $x$ & & $x$ & $\mathbf{x}$ & $x$ \\
\hline -- & -- & - & -- & - & - & $x$ & $\mathrm{x}$ & $x$ & $x$ & $\mathbf{x}$ & \\
\hline - & -- & -. & -- & -- & - & & & $x$ & & & $x$ \\
\hline $\mathbf{x}$ & $\mathbf{x}$ & $\mathbf{x}$ & $\mathbf{x}$ & $\mathbf{x}$ & $\mathbf{x}$ & -. & -- & - & -. & -- & .. \\
\hline $\mathrm{x}$ & $\mathrm{x}$ & $x$ & $\mathbf{x}$ & $\mathbf{x}$ & $\mathrm{x}$ & -- & -- &.- & -- &.. & .. \\
\hline .. & -. & - & -- & - & - & $x$ & $\mathbf{x}$ & $\mathbf{x}$ & $x$ & & $\mathbf{x}$ \\
\hline & & $\mathbf{x}$ & $x$ & & $x$ & $x$ & $\mathrm{x}$ & $\mathbf{x}$ & $x$ & $x$ & $x$ \\
\hline -- & -- & -- & & $\mathbf{x}$ & & -. & -- & -- & -- & -- & - \\
\hline -- & -- & -- & & & $\mathbf{x}$ & - & - & -- & -- & -. & - \\
\hline & & $\mathbf{x}$ & & & $\mathbf{x}$ & -. & - & -. & .- & -. & -- \\
\hline & & $\mathbf{x}$ & & $x$ & $x$ & $\omega$ & -- & - & -- & -- & - \\
\hline $\mathbf{x}$ & & $\mathbf{x}$ & & & $\mathbf{x}$ & $\mathbf{x}$ & & * & $x$ & & $\mathbf{x}$ \\
\hline $\mathbf{x}$ & $x$ & $\mathbf{x}$ & $\mathrm{x}$ & $x$ & $\mathbf{x}$ & $\mathbf{x}$ & $\mathbf{x}$ & & $\mathbf{x}$ & $\mathbf{x}$ & $\mathbf{x}$ \\
\hline $\mathbf{x}$ & & & $\mathbf{x}$ & $x$ & $\mathbf{x}$ & -- & -- & -. & -. & .. & -- \\
\hline- & $\overrightarrow{-}$ & - & $\mathbf{x}$ & & & .- & -- & -- & -- & - & - \\
\hline $\mathbf{x}$ & & & & -- & -- & -- & - & - & -. & - & - \\
\hline
\end{tabular}

accidental occurrence within the state; about 110 species are of rare or irregular occurrence or present in the state only during spring and fall migration. Eliminating the migrants and the species of rare or accidental occurrence, we find that about 185 species of birds in the Smith \& Parmalee list occur fairly regularly in the state during either winter or summer or during both seasons. This number is close to the number in our list.

During the 1906-1909 and the 19561958 censuses, only nine species of birds, bobwhite, mourning dove, yellow-shafted flicker, downy woodpecker, horned lark, blue jay, crow, house sparrow, and American goldfinch, were recorded in all years and zones in both winter and summer. In addition, chickadees, which were not identified to species, were recorded in all zones in all census years.

Species recorded in all years and zones in summer and in one or two, but not all three, zones in winter were the sparrow hawk, killdeer, red-headed woodpecker, robin, bluebird, loggerhead shrike, redwinged blackbird, grackle, cowbird, towhee, and field sparrow. In addition, meadowlarks, which were not identified to species, were seen in all zones in summer and in a number of zones in winter.

Species recorded in all years and zones in winter and in one or two, but not all three, zones in summer were the red-bellied woodpecker, tufted titmouse, white-breasted nuthatch, cardinal, and 
song sparrow. In addition, the red-tailed hawk and hairy woodpecker were recorded in a high percentage of years and zones in both summer and winter.

Species recorded in all years and zones in summer only were the green heron, upland plover, yellow-billed cuckoo, chimney swift, eastern kingbird, crested flycatcher, phoebe, wood pewee, barn swallow, house wren, catbird, brown thrasher, red-eyed vireo, yellowthroat, orchard oriole, Baltimore oriole, indigo bunting, dickcissel, and grasshopper sparrow.

Species recorded in all years and zones in winter only were the junco and tree sparrow.

\section{Avifaunal Differences Between Censuses}

Of the 177 species of birds recorded in the two census periods, 104 appear on the lists for both periods, table 55. Fourteen species identified in 1906-1909 were not identified in 1956-1958.

Species recorded in 1906-1909 but not in the later series of censuses were the lesser scaup, prairie chicken, sora, woodcock, least flycatcher, yellow-bellied flycatcher, Swainson's thrush, Swainson's warbler, magnolia warbler, chestnut-sided warbler, and palm warbler, all in summer; and the golden eagle, bald eagle, and snow bunting, all in winter. Seven of these species were late spring migrants. The golden eagle, bald eagle, sora, woodcock, Swainson's warbler, and snow bunting are either uncommon or have such specialized habitat requirements that their appearance on the 1906-1909 list but not on the 1956-1958 list does not necessarily imply a population change.

The prairie chicken was recorded for both summers in the early census and not at all in the later series. The population changes in this species have been studied by Yeatter (1943).

Fifty-nine species of birds were identified in 1956-1958 but not in 1906-1909. Included in this group were three introduced species, the ring-necked pheasant, gray partridge, and starling, which have become well established in Illinois since the time of the first surveys. Another introduced species, the rock dove, was not recorded in 1906-1909. This dove was so closely associated with human habitations at the time of the early study that it was considered to be a domestic species and therefore was not censused.

Native species not listed in 1906-1909 but listed in 1956-1958 (probably because between the two census periods they had increased in number or distribution in the state) were the common egret, little blue heron, black vulture, tree swallow, roughwinged swallow, Bell's vireo, prairie warbler, western meadowlark, yellow-headed blackbird, and Brewer's blackbird.

The majority of species listed in 19561958 but not in 1906-1909 were marsh or forest species. Their absence from the early list probably reflects only the fact that little acreage of marsh and forest was censused in 1906-1909. Species in this category were the horned grebe, least bittern, American bittern, mallard, black duck, blue-winged teal, wood duck, Cooper's hawk, Virginia rail, common gallinule, American coot, common snipe, black tern, horned owl, saw-whet owl, whippoor-will, pileated woodpecker, yellowbellied sapsucker, long-billed marsh wren, hermit thrush, blue-gray gnatcatcher, ruby-crowned kinglet, yellow-throated vireo, worm-eating warbler, cerulean warbler, yellow-throated warbler, pine warbler, ovenbird, Kentucky warbler, and hooded warbler.

Other species that were not listed in 1906-1909 and that represent specialized habitat situations not widely covered in the early surveys were the blue goose, Canada goose, herring gull, and ringbilled gull.

Certain species recorded in 1956-1958 but not in 1906-1909 occur either rarely or erratically in the state in summer or winter; hence, we would not necessarily expect to encounter them in both surveys, or in either. In this category were the short-eared owl, water pipit, Sprague's pipit, cedar waxwing, northern shrike, rusty blackbird, blue grosbeak, Le Conte's sparrow, Harris' sparrow, white-crowned sparrow, and Smith's longspur.

\section{Annotated List of Common Species}

Most of the species that make up the bulk of the bird population of Illinois are discussed in detail in the following pages. Some of the important forest species are not included because only limited 
population data for the forest habitat were avisilible from the 1907-1909 censuses.

The population figures presented in this section were derived from density data for all habitats censused in 1906-1909 and 1956-1958. Not all of these population figures agree with data in habitat tables +-54 . The data in the tables refer only to fields or blocks of habitat, whereas the figures in the species accounts include edge acreage as well as fields or blocks. For example, the sparrow hawk was not included in table 15 because it was not seen in fields of ungrazed grassland; however, ungrazed grassland is listed as a favored habitat in the species account of the sparrow hawk because this species was found in an edge situation, that is, grassland along roadsides.

Turkey Vulture.-In summer, the turkey vulture was recorded in both the central and southern zones of Illinois, but, in winter, it was found only in the southern zone. The summer data on this species present a paradox, suggesting that after 1909 there was a slight increase in the central zone population and a marked decrease in the southern zone population. We estimate that in 1907-1909 there were less than 7,000 turkey vultures (breeding population) in the central zone, while in the southern zone the populations numbered about 76,000 birds in 1907 and 43,000 in 1909. By 1957-1958, there were about 10,000 vultures in the central zone and only $15,000-16,000$ in the southern zone.

Range extension in a given species is often associated with population increase, but, in the turkey vulture, range extension appeared to be associated with thinning of the population. Figures for the early censuses should be considered minimal because of the small acreage of forest (primary nesting habitat) censused. According to the census data, vultures are likely to be encountered in almost any Illinois habitat. In 1907-1909, most vultures seen were in pastureland; this finding reflected, in part, the large acreage of pastureland covered.

Winter data, as well as summer data, indicate a population decline in this species. In 1906-07, turkey vultures wintering in Illinois were concentrated in the southern zone, particularly in forest and pastureland, where the estimated population was about 690,000 vultures-a population far exceeding the entire state population in summer. Though we saw turkey vultures in the winters of 1956-57 and 1957-58, none came within the census transects, and we judge that the winter population in those years was slightly less than the summer levels.

Weather may have had a profound effect on the winter populations of vultures, both in 1906-07 and in the later years. The winter of 1906-07 was unseasonably warm and wet, conditions that may have favored a high winter population. In hoth 1956-57 and 1957-58, the early part of the winter was unseasonably warm, but, in January, temperatures fell sharply, and the middle and late parts of winter were unusually cold. The cold may have pushed vultures to wintering grounds farther south. Despite the weather differences between the winter of 1906-07 and the winters of 1956-57 and 1957-58, the difference in vulture populations between the two census periods was so great that we feel the winter data corroborated the conclusion, from summer data, that the turkey vulture population in Illinois was reduced greatly between 1909 and 1956 .

We can only speculate as to the cause of the reduction. The primary nesting habitat (forest) actually increased slightly in acreage after 1909, but a favored foraging habitat, pasture, was greatly reduced. The concurrent spreading and thinning of the population may be related to availability of food, and this, in turn, may be related to man's changing practices in livestock management.

Red-Tailed Hawk. - The ForbesGross strip census method is not well suited for censusing hawks. While census takers are likely to see hawks, wary species such as the birds of prey are very unlikely to come within the census transect lines. Our population figures for such species should be considered minimal; they are useful primarily for comparisons within this study.

The red-tailed hawk was seen in a broad variety of habitats throughout the state. It was seen within the census transects chiefly in woods and shrubby forest edge, probably because reduced visibility in these habitats permitted the census 
takers to come within sight of the birds, and also because red-tails were more prone to approach census takers in or near the nesting habitat than in other areas. Specific population figures based on the censuses are questionable, but a few generalizations may be derived from them.

Despite the large acreage of forest nesting habitat in southern Illinois, the summer population of the red-tail in the southern zone was decidedly low by comparison with populations in the central and northern zones. We estimate that the red-tail population in 1957 and 1958 numbered about 25,000 birds in each of the two zones farther north, but less than 15,000 in the southern zone. The 1958 statewide population was well below the 1957 level. Because relatively little forest was censused in the summers of 1907 and 1909 , comparisons of breeding populations of the red-tail in the two study periods are not warranted. Acreages of winter habitats censused in the two periods were nearly equal.

Winter populations of the red-tailed hawk tended to be lower than summer populations in the northern and central zones of the state but higher than summer populations in the southern zone. This pattern followed the generalized picture of seasonal shift in the Illinois bird population, in which southern zone populations increased from summer to winter while populations to the north decreased. The census data indicated that the winter population of the red-tail in 1906-07 was much higher than that in either 1956-57 or 1957-58. We estimated that about 90,000 red-tails wintered in southern Illinois in 1906-07; the 1956-57 and 1957-58 winter populations in this zone were about 35,000 and 19,000, respectively. Christmas count data presented by Graber \& Golden (1960:13) indicated that the 1906-07 population in central Illinois, at least, was above average.

Sparrow Hawk.- The sparrow hawk was encountered throughout the state both summer and winter in all zones, but the census data indicated that there were some marked changes in the distribution pattern of this falcon between 1909 and 1956. In 1907-1909, the bulk of the state breeding population was in the southern zone, while, in 1957-58, most of the population was in the central (particularly) and northern zones of the state.

This species had a broad ecological distribution, but ungrazed grasslands (mean density : 1.2 sparrow hawks per 100 acres in 1957-1958) and fallow fields (1.1 per 100 acres in 1907-1909) were by far the most favored foraging habitats in summer. Other important habitats (pastures, fields of mixed hay, and cornfields) had densities of not more than 0.5 sparrow hawk per 100 acres.

There was an apparent marked reduction in the statewide population of the sparrow hawk between 1909 and 1957 . The change in the southern zone was particularly marked.

The summer populations of the sparrow hawk in Illinois numbered about 90,000 birds in 1907 and 197,000 in 1909; in each of these years, about 70 per cent of the state population was in the southern zone. The difference in population between the two years was consistent from zone to zone; that is, in each zone the 1909 population was higher than the 1907 population. In 1957 and 1958, summer populations (maximum estimates) of the sparrow hawk in Illinois were 33,000 and 78,000 , respectively. In each of these years, about 65 per cent of the Illinois population was in the central zone, and the southern zone population was negligible.

The drastic reduction in acreage of pasture in southern Illinois may have contributed to the decline of the population. At the time of the early censuses, pastureland characteristically contained widely scattered, large trees that may have offered nesting cavities for the sparrow hawk. In recent years, farmers have become less tolerant of trees at the margins of their cultivated lands. Such trees are ideal nesting sites for the sparrow hawk, and their removal was detrimental to the bird. The increase in forest acreage in Illinois since 1907 would seem to have been more of a hindrance than a help to the sparrow hawk, which requires open foraging areas. Presumably, the sparrow hawk could compete with most other species of cavity-nesting birds, but, by sheer force of numbers, the introduced starling may have had a depressive effect on the sparrow hawk population.

Winter data, as well as summer data, 
indicated a decline in sparrow hawk numbers between the two census periods. In winter of both census periods, the population was largely concentrated in the southern and central zones. Favorite foraging habitats of the sparrow hawk in winter were cornfields (stubble or mechanically harvested), hayfields, small grain stubble, and pastures, all of which had densities of about 1 sparrow hawk per 100 acres in southern Illinois.

In 1906-07, approximately 135,000 sparrow hawks were wintering in Illinois. About 81 per cent of the winter population was in the southern zone. In the winters of 1956-57 and 1957-58, populations of the sparrow hawk were estimated to have numbered respectively 60 ,000 and 54,000 individuals; between 60 and 70 per cent of the state population was in the southern zone. Between 1907 and 1957, the summer (June) and winter (January) populations of the sparrow hawk showed about the same percentage of decline (60 per cent). The difference between the minimum 1907-1909 population $(90,000)$ and the maximum 19571958 population $(78,000)$ represented a decrease of about 13 per cent.

Bobwhite.-Of the four galliform birds (prairie chicken, bobwhite, gray partridge, and ring-necked pheasant) recorded in the census strips, the native bobwhite was the most widely distributed and abundant. The strip census method, intended primarily for censusing songbirds, is a poor method for censusing game birds.

Quantitative data on bobwhite populations were highly variable in both census periods, but populations were consistently highest in the southern zone, diminishing progressively to the north. For example, in 1909, summer population densities for the quail in pastureland were about 6.8 birds per 100 acres in the southern zone, 5.2 in the central, and 1.0 in the northern.

Accompanying the progressive north to south increase in bobwhite numbers was a parallel increase in ecological distribution; in the southern zone, bobwhites were counted in virtually every type of habitat but urban areas. Habitat preference of the bobwhite appeared to have been similar in 1907-1909 and 1957-1958. The most consistently favored summer habitats were shrubbery of all types, orchards, hayfields. ungrazed grasslands, and pasture. Densities of bobwhite populations in various summer habitats in southern Illinois in 1957-1958 were 137.0 birds per 100 acres in hedgerows, 45.0 in edge shrubs, 12.0 in mixed hay (3.3 in 1907-1909), 6.4 in orchards ( $S .8$ in 1907-1909), 5.6 in ungrazed grassland ( 4.8 in 1907-1909), 5.0 in pastures (5.1 in 1907-1909), t.6 in shrub-grown areas (8.0 in 1907-1909), 3.5 in red clover ( 7.7 in 1907-1909), 2.2 in fallow fields $(2.5$ in 1907-1909), 1.5 in wheat (in 1907-1909, 4.2 in wheat and 5.5 in oats), 1.2 in forest, and 0.8 in corn (0.t in 1907-1909). There were no consistent differences in density between 1907-1909 and 1957-1958; densities in grassland habitats in the two study periods were roughly comparable.

From census data and crop acreage statistics, we estimated that the June population of the bobwhite in the southern zone was about 446,000 birds in 1907 and $6+3,000$ in 1909 . A difference in population density in these two years was expressed in almost every habitat in both the southern and central zones, and the difference was even more striking in the central than in the southern zone (central zone estimates: 53,000 birds in 1907; 169,000 in 1909). For the northern zone, the 1909 estimate was about 30,000 birds (no northern zone data are available for 1907).

In terms of numbers and geographic distribution, the summer quail population appears to have changed little since the first study period. The statewide population was at least 500,000 birds in 1907 (1907 data lacking for northern zone) and 842,000 in 1909 ; in these years, about 80 per cent of the state population was concentrated in the southern zone and only about 4 per cent was in the northern. In 1957, the estimated population was about 599,000 bobwhites, 80 per cent of which were in the southern zone and only 6 per cent in the northern zone. Annual fluctuations were notable at the time of the second study period, and the 1958 state population was up to at least 662,000 birds. The population increase in the state between 1957 and 1958, like that in the central and southern zones between 1907 and 1909, was consistent from zone to zone and from habitat to habitat. 
While the numbers and geographic distribution of the bobwhite were about the same in the two study periods, the species has recently faced some noteworthy ecological changes. Grassland pasture, probably the most important single summer habitat in 1907-1909, had decreased by 1957 to less than one-third of its former area. With this change, havfields, which increased in acreage, probably became the primary summer habitat for the bobwhite. Our population estimates, for both the early and recent census years, probably slighted the marginal or edge habitats such as roadsides and hedgerows. Some of the unaccounted acreage for the state (about $2,000,000$ acres not accounted for in 1907 1909 and $3,000,000$ in 1957-1958) may represent such high-density quail habitats.

The quail populations were much larger in winter than in early summer (all census years) and shifted more to woody habitats, fallow fields, and hayfields. Small grain fields (stubble) were important winter habitats; pastureland, even in 1906-1907, was less important in winter than in summer. In 1906-07, when corn was hand picked, bobwhites frequented this cornstalk habitat, particularly in southern Illinois; changes in harvesting methods virtually eliminated this special habitat.

The January, 1907, population of quail in the southern zone was estimated to be about $1,892,000$ birds. The central zone had about 124,000 bobwhites and the northern zone 66,000 , making a total of about $2,082,000$ in the state. In the winter of 1956-57, the state quail population numbered about $1,773,000$ birds; the number was down to 599,000 by June, 1957, up to $2,235,000$ in January, 1958, and down to 662,000 in June, 1958. The amount of fluctuation was about the same in the two study periods. As quail numbers are probably at a peak in late summer and minimal in spring, our figures do not represent maximum annual fluctuations. The reader should bear in mind that, for the quail, the strip census method may be more effective in winter than in summer; this difference would tend, of course, to accentuate the difference between our winter and summer estimates of population. The figures imply that the mortality rate of quail between January and June is high (60 and 68 per cent, respectively, in 1957 and 1958) and that good production of young in one nesting season does not necessarily increase the nesting population in the following year. There are, apparently, differences in rates of production and mortality between areas with high and areas with low population density. In the early census period, the ratio between winter (1906-07) and summer (1907) populations was about $4: 1$ in southern Illinois and $3: 1$ in central Illinois; in the later census period, the ratio between winter (1957-58) and summer (1958) populations was $3: 1$ in southern Illinois and $2: 1$ in central Illinois. In all years, both production and mortality were relatively higher in the southern zone (high-density area) than in the central zone (low-density area). These characteristics tend to make the total Illinois quail population unchanging from year to year and, coupled with the subtle nature of the habitat changes, help to account for similarities between the 1906-1907 and the 1956-1958 figures.

Killdeer.-Only five species of shorebirds, killdeer, American woodcock, common snipe, upland plover, and spotted sandpiper, were encountered in the censuses. Of these, the killdeer and upland plover were common enough to warrant special discussion.

In summer, the killdeer was counted in all zones as well as all years but, in winter, it was detected only in the southern zone and only in very small numbers. Though the killdeer occurred throughout the state in summer, the density of killdeer populations varied from zone to zone in an interesting and unexplained ecological pattern. Cornfields provided a relatively high-density habitat in the southern zone ( 4.3 birds per 100 acres in 1957-1958; t.6 in 1907-1909), but a low-density habitat in the central zone $(0.2$ in $1957-$ $1958 ; 0.3$ in 1907-1909). Conversely, pastureland had higher killdeer populations in the central zone ( 1.2 birds per 100 acres in 1957-1958; 1.8 in 19071909) than in the southern zone (0.8 in $1957-1958 ; 0.7$ in 1907-1909). In this ecological variation, northern zone populations tended to follow central zone populations.

The killdeer is one of the species of 
birds that would seem to be favored by row-crop agriculture. It favors habitats with large amounts of bare ground, and population densities for this species tend to fall as vegetative cover increases in a habitat. Densities of killdeer populations in various habitats in southern Illinois in 1957-1958 were 10.6 birds per 100 acres in marshland (dry margins), 10.0 in plowed ground (2.2 in 1907-1909), 8.2 in alfalfa, 4.3 in corn ( 4.6 in 1907-1909), 4.1 in soybeans ( 7.7 in beans in 1907$1909), 0.8$ in pasture (0.7 in 1907-1909), $0 . t$ in fallow fields (0.3 in 1907-1909). In 1957-1958, mixed hay and red clover had negligible populations of killdeers in the southern zone; in the central zone, red clover had 2.2 birds per 100 acres (2.1 in 1907-1909), and, in the northern zone, mixed hay had 2.2 birds per 100 acres. Generally in hayfields, the killdeer favors spots where the vegetation is thin and low; thus, the population in some hayfields mav be high. The best of the habitats, as shown by high population, were the marshes (principally the dry margins) in northern Illinois, where the density was 11.5 birds per 100 acres. Sand prairie in the northern zone had 2.4 killdeers per 100 acres. All of the above-mentioned habitats were probably both nesting and foraging sites for killdeers.

There is no indication that habitat preferences of the killdeer changed between 1909 and 1957. Population densities for given hahitats were similar in the two periods. The census data indicated a northward trend in the state killdeer population between 1909 and 1957. In many habitats, population densities in the northern zone increased during this period. In pastures of this zone, for example, there were 1.0 killdeer per 100 acres in 1909 and 2.9 killdeers per 100 acres in 1957-1958; in cornfields, 0.0 in 1909 and 2.6 in 19571958: in mixed hay, 0.0 in 1909 and 2.2 in 1957-1958. In June, 1909, the southern zone of Illinois had an estimated population of about 339,000 killdeers ( 83 per cent of the state population); the population diminished rapidly and progressively to the north, and the northern zone had only about 14,000 killdeers (less than 4 per cent of the state total). In 1957 and 1958, populations in the northern zone were, respectively, 119,000 (36 per cent of stalte total) and 125,000 (2t per cent of state total).

By our estimates, June populations of the killdeer in the state numbered about 406,000 birds in $1909,326,000$ in 1957 , and 524,000 in 1958. Year-to-year variation in the breeding population, obviously, was high. Because the killdeer nests on the ground in a minimum of cover, it may be particularly influenced by weather during the nesting season (April-June).

By winter of each year, migration has carried most of the killdeer population south of lllinois. A few killdeers may be found even in the northern zone in winter, but populations north of the southern zone are usually negligible. With the change in season, there is also a habitat change, and, in both the early and recent winter censuses, the killdeer was found to favor clover and alfalfa fields, almost to the exclusion of other habitats. The 1906-07 and 1956-57 winter populations of the killdeer were comparable (about 157,000 birds each winter). By comparison, the 1957-58 population was very low (about 11,000 birds). The winter census of 1957-58 was conducted about 3 weeks later in the year than the censuses of 1906-07 and 1956-57. Southern Illinois experienced unusual cold in 1957-58. which probably pushed the killdeer population farther south than usual.

Upland Plover.-The upland plover was recorded throughout the state in summer; highest frequencies were in the central and northern zones.

This plover was found in a variety of open-field habitats-pasture, havfields, fallow fields, small grain, corn, and soybeans; the greatest densities were in pastureland and hayfields (especially red clover).

Densities of upland plover populations were, in certain habitats, roughly comparable in the northern and central zones and conspicuously lower in the southern. Densities in Illinois pastureland in 19071909 were 3.1 birds per 100 acres in the northern zone, 2.0 in the central, and 0.3 in the southern. Population densities of the upland plover in various habitats of the northern and central zones (combined) in 1957-1958 and 1907-1909 were 7.5 birds per 100 acres in red clover fields (22.5 in 1907-1909), 2.2 in mixed hay and alfalfa (1.3 in 1907-1909), 0.7 in 
pastures (2.4 in 1907-1909), 0.8 in small grain fields (0.1 in 1907-1909), and 0.5 in corn (0.5 in 1907-1909).

Both pasture and hayfields were recorded as nesting habitats of the upland plover; the other habitats listed probably represented only foraging areas. The ecology of the species seems to be changing. The density data suggest that pasture (a declining habitat) is becoming less important to the plover, while mixed hay and alfalfa are hecoming more important. In the southern zone, alfalfa was the most important plover habitat in the second census period.

While the range of the upland plover in the state did not change between 1909 and 1957, the distribution of the population changed considerably. In 1907-1909. about half $(140,000$ birds $)$ of the state population (283,000 birds) was found in the northern zone, and the remainder was fairly evenly divided between the central and southern zones. By 1957-1958, the state population $(208,000$ in 1957 ; 177,000 in 1958) had declined; in both years, most (60-80 per cent) of the population was in the central zone, and less than 15.000 birds of this species were in the southern zone.

The decline of the state population and the shift of the population toward central Illinois may be related to habitat changes. The great loss in pastureland acreage was probably a primary factor in the decline. The density data suggest that the quality of pastures (as plover habitat), as well as the acreage, declined. The relative increase of the plover in the central zone reflects, to some extent, the increase of red clover acreage in this zone after 1909.

Mourning Dove.-In all census years, the mourning dove occurred throughout the state in both summer and winter; the winter populations tended to be concentrated in the southern zone.

No species of bird in the state had a broader ecological distribution than the mourning dove, which was found nesting and foraging in virtually all terrestrial, shrub, and arboreal habitats. Dove populations were highly variable in density from habitat to habitat and from zone to zone. The 1957-1958 densities of summer dove populations in shrub-grown areas were 11.1 birds per 100 acres in southern Illinois, 12.2 in the central zone, and 15.5 in the northern. By contrast, densities in soybean fields were 6.6 per 100 acres in the southern zone, 4.3 in the central zone, and 3.6 in the northern.

Rated on the basis of population density (all census years considered), habitats most favored by the mourning dove in summer were marginal or edge shrubbery, hedgerows, sweet clover fields, prairie or ungrazed grasslands, orchards, marshes, urban residential areas, and fallow fields.

Average densities of mourning dove populations in various summer habitats in the state in 1957-1958 were $1+2.5$ birds per 100 acres in edge shrubs, 97.6 in hedgerows, 39.5 in sweet clover, 38.0 in ungrazed grassland (10.7 in 1907-1909), 32.9 in orchards (+6.5 in 1907-1909), 31.6 in fallow fields (10.6 in 1907-1909). 29.7 in marshes, 28.6 in urban and rural residential areas (1.8 in 1907-1909), 15.5 in red clover (9.3 in 1907-1909), 12.0 in shrub-grown areas (17.3 in 1907-1909), 7.5 in plowed fields (14.1 in 1907-1909), 6.0 in wheat fields (13.8 in 1907-1909), $4.8 \mathrm{in}$ alfalfa, 4.6 in mixed hay (6.2 in 1907-1909), +.5 in soybean fields, 3.6 in forest (10.2 in 1907-1909), 2.6 in pastures (5.t in 1907-1909), 2.6 in cornfields ( $4 .+$ in 1907-1909), and 1.3 in oat fields (2.9 in 1907-1909). A small acreage of savanna-type habitat had about 11 doves per 100 acres.

Harvesting of crops greatly alters the ecological distribution of the dove, for this species tends to concentrate in fields where the crops have been cut. For example, in 1907-1909 in southern Illinois, there were $7+$ doves per 100 acres in cut wheat fields and only 17 per 100 acres in uncut wheat. Similarly, in 1957-1958 in the northern zone, there were 11 doves per 100 acres in mowed havfields and 3.6 in uncut hayfields.

Certain apparent habitat preferences of the mourning dove in summer are noteworthy. The high density of birds at marshes may well represent concentrations of doves seeking water. The fallow-field habitat was genuinely favored by the dove, and our experience showed this was the open-field type that was most used for nesting. Clover fields seem to have been much favored over mixed hay and alfalfa fields. Most of the doves found in the 
hayfields, particularly those in harvested hayfields, were probably foraging. Wheat, generally a very poor bird habitat, had relatively high populations of doves. Hanson \& Kossack (1957:17S; 1963:92) have pointed out the importance of wheat in the mourning dove diet. In 1907-1909, rye was a much-favored habitat in southern Illinois-probably even more than wheat-but the sample was too small to give a valid density figure. Oat fields were the poorest of the dove habitats in all zones of the state. Open space appears to be an important characteristic of all of the dove habitats with high population density; the difference between dove populations in urban areas (high density) and those in forests (low density) may in part reflect this characteristic.

The density figures presented above represent mostly, but not solely, adult populations. While we did not include identifiable juveniles in the calculations, some well-grown birds of the year were surely counted as adults. The figures include both nesting and foraging doves in each habitat. In the censuses of 1907-1909 and 1957-1958, several ground nests of the mourning dove were found in openfield habitats, but we have no way of knowing what per cent of the population found in open fields represented nesting birds. We judge that only a few habitats (shrub, orchard, urban area, and fallow field) have high nesting densities of the mourning dove, and these habitats represent a small per cent of the land acreage of the state.

In all but four of the summer habitats (fallow field, ungrazed grassland, red clover, and urban and rural residential areas), densities averaged higher in 19071909 than in 1957-1958. There is evidence of a northward shift in the dove population between 1909 and 1957. In 1907-1909, population densities of the mourning dove in several habitats (pasture, prairie, orchard, corn, and plowed fields) tended to be highest in the southern zone and lowest in the northern; in 1957-1958, dove populations in some of these habitats showed highest densities in the northern zone, lowest in the southern. For example, in pastureland in 19071909 there were about 2.1 doves per 100 acres in the northern zone, 5.0 in the cen- tral, and 6.3 in the southern, but in 195i1958 densities were 2.9 in the northern zone, 2.9 in the central, and $1.7 \mathrm{~m}$ the southern. Of all the habitats, only orchard was consistent in having highest densities in the southern zone in all years.

Some of the patterns of summer distribution seemed contradictory. Why should orchards have had highest concentrations of dove populations in the southern zone, while shruh and urhan residential areas had highest concentrations in the northern zone? Some distribution patterns may have been related to habitat availability. For instance, shrub acreage was low in the northern zone, and doves may have tended to pack the available area of this excellent nesting habitat. 'The limited acreage of shrub areas in northern Illinois may also have accounted for the high densities of dove populations in the northern urban areas.

Within a given habitat or a particular geographic area, mourning dove populations may fluctuate greatly from year to year. Hanson \& Kossack (1963:115-7) reported great year-to-year fluctuations in the habitats and area they studied. In the statewide and zonewide populations of the periods reported here, we found that population fluctuations in the mourning dove were remarkably small in comparison with population fluctuations in many other species.

Our estimates of the statewide mourning dove populations were as follows: $2,+38,000$ in 1909 (about 2,500,000 in 1907 , as estimated from central and southern zone data), 2,000,000 in 1957, and $2,000,000$ in 1958. Such small fluctuations were, perhaps, to be expected in a broadly distributed species, which may suffer losses in one zone or habitat and balance them by gains in another zone or another habitat. Because dove populations raried little from one census year to the next, we believe that there was an actual decline in the state population between the two census periods amounting to about 19 per cent of the 1907-1909 level. Most of the loss appears to have been in the southern zone population, which dropped from about $1,500,000$ birds in $1907-1909$ to about $1,100,000$ in 19571958. The 1957-1958 dove populations in the northern zone (about 400,000 
birds) and the central zone (about 500,000 birds) were almost the same as the 1907-1909 populations in these zones.

Winter populations of the mourning dove in the northern and central zones were sparse in all census years; the southern zone had more than 90 per cent of the state population in winter.

Some noteworthy changes took place between $1906-07$ and $1956-57$ in the winter dove population and its ecology. In 1906-07, most of the wintering doves of the state were found in one habitat, cornstalk (picked corn) fields, where population densities were 0.7 bird per 100 acres in the northern and central zones and 35.6 per 100 acres in the southern zone. Changing agricultural methods virtually eliminated this preferred habitat. The agricultural replacement for cornstalk habitat was the mechanically picked cornfield, which had average densities, in 1956-57 and 1957-58, of $0.3,0.5$, and 3.7 doves per 100 acres in the northern. central, and southern zones, respectively. Population densities in other winter habitats in the southern zone (1956-57 and 1957-58 average) were 103.8 doves per 100 acres in shrubs, 23.1 in bean stubble, 9.0 in ungrazed grass, 8.0 in forest. 1.9 in fallow fields, 1.3 in hay, 1.0 in wheat, and 0.8 in small grain stubble. The most consistently used habitats were forest and cornfields in the northern and central zones and shrub-grown areas and cornfields in the southern zone.

The mourning dove apparently wintered farther north in much higher numbers in 1956-1958 than in 1906-07. In 1906-07, a notably mild winter, the state dove population (all habitats) numbered about 350,000 birds; the lower population of the two later censuses (1957-58) was about $1,200,000$ birds, despite the fact that weather conditions were more adverse to wintering doves in 1957-58 than in 1906-07. In both 1906-07 and 1957-58, dove populations in the northern and central zones (combined) numbered less than than 50,000 birds, a negligible part of the state total. The increase noted above was primarily in the southern zone of the state. Year-to-year variation in the winter dove population was high, and the difference between the 1956-57 and 1957-58 populations warrants discussion. State populations in 1956-57 and 1957-58 numbered about 2,000,000 and 1,200,000 birds, respectively. A factor that may have had some bearing on the reduced number in 1957-58 was the unusual and prolonged cold during the fall dove migration season (1957), which may have effected a more extensive evacuation of doves from the state. In addition, our census schedule was late in 1957-58 (running into February), and extreme cold in January and February may have pushed doves farther south. Censuses conducted in late December, 1956, and early January, 1957, when mild winter conditions prevailed, showed a dove population for the northern and central zones of about 130,000 birds. By contrast, the populations in these zones, following prolonged cold in January and early February, 1958, were negligible. These data, coupled with the great increase in the population of the southern zone between the winters of 1906-07 and 1956-57, indicate that the northern edge of dependable winter range for the mourning dove in Illinois is south of latitude +0 degrees.

The increase that occurred in the winter dove population of the southern zone between $1906-07$ and $1956-57$ is puzzling, particularly in view of the apparent decline in the breeding population. The change follows a pattern of northward range extension which we can observe in many species of birds. Regardless of the underlying cause of the range extension, it is conceivable that the populations involved may tend to concentrate, that is, increase where some climatic or other harrier delimits the range extension. Such a mechanism may be involved in the increase in the winter dove population of Illinois.

Because nesting populations of the mourning dove have low densities in openfield habitats, intensive cultivation, especially when accompanied by removal of such high-density dove habitats as edge shrubs, hedgerows, and orchards, is detrimental to the dove. Activities of the expanding human population in urban areas may compensate to some extent for the loss of nesting sites in rural areas, because plantings in residential urban areas have large dove populations. The mourning dove may, in fact, be adapting to this expanding habitat, as the early censuses 
showed few doves in urban residential areas.

Cuckoos.-In all census years combined, the two cuckoos were counted in a ratio of about 14 yellow-bills to 1 blackbill.

The rellow-billed cuckoo occurred throughout the state in summer of all census years; it was most abundant in the southern zone, least abundant in the northern. In most habitats, population densities were highest in the southern zone. In edge shrubbery in 1957-1958, there were 10.0 birds per 100 acres in the southern zone and 8.4 in the northern zone.

Densities of yellow-billed cuckoo populations in various summer hahitats in the southern zone in 1957-1958 were 45.7 birds per 100 acres in hedgerows, 10.0 in edge shrubbery, 3.9 in orchards (6.6 in $1907-1909), 1.6$ in shrub-grown areas (12.0 in 1907-1909), 0.8 in pastures $(0.2$ in 1907-1909), 0.6 in forest (3.3 in 19071909). In 1907-1909 only, the yellowbilled cuckoo was found in residential habitat ( 6.0 birds per 100 acres), wheat fields $(0.7)$, and mixed hay $(0.5)$.

The density data suggest that the cuckoo population declined between 1909 and $195 \%$. Our estimates of the state populations in different years were 167,000 hirds in $1907,383,000$ in $1909,92,000$ in 1957 , and 59,000 in 1958. The estimates indicate a notahle population decrease.

Habitat changes that eliminated some of the best cuckoo nesting areas in the state undoubtedly had some effect on the cuckoo population; among these changes were the decrease in the acreage of orchards by 1958 to about one-tenth of the 1909 acreage and the destruction of many hedgerows and roadside shrubs along field boundaries. An increase in forest-edge habitat in southern Illinois compensated but little, for this had become a low-density habitat for cuckoos. Cuckoos were found in residential areas in 1907-1909 but not in 1957-1958. The difference may reflect some change in the nature of plantings near human habitations.

Chimney Swift.- In all census years, the chimney swift was found in summer throughout the state.

Before white settlement, chimney swifts probably placed their nests in hollow trees. They may still use such nesting sites, but most of the population nests in man-made chimneys. This very specialized nesting habitat and the special feeding method of the chimney swift complicate discussion of populations of this species. In urban residential areas in 1958, we counted 24.4 swifts per 100 acres in the southern zone, 26.8 in the central zone, but only 14.4 in the northern zone. On the other hand, population densities of the swift foraging in nonurban areas tended to he highest in the northern and central zones. The urban densities were lowest where the availability of nesting sites was highest. Most of the state's urban acreage is in the northern zone ( 71 per cent in northern zone, 13 per cent in central zone, and 16 per cent in southern zone).

Because of its great mobility, the swift was encountered in every habitat censused. Populations were not distributed over the various habitats in proportion to the acreage distribution of the habitats. For example, cornfields comprised the largest (in terms of acreage) single habitat in the state, and the largest habitat sampled, but only about 11 per cent of the swifts counted were over cornfields; about 35 per cent were over hayfields, which had about half the acreage of cornfields.

In all census years, hayfields (various types), pasture, and fallow fields were the favored foraging habitats of the swift. Population densities of foraging swifts over hayfields of all types (an expanding habitat) were about the same (average density 3.4 birds per 100 acres) in $1957-1958$ as in 1907-1909, but in pastureland (a diminishing habitat) swift numbers showed an increase between 1907-1909 (1.2 per 100 acres) and 19571958 ( 4.6 per 100 acres). 'These observations suggest that the swift has been consistent in habitat preferences through the years. Populations over alfalfa were comparable to those over mixed hay. Red clover and sweet clover fields were particularly favored (average density: 7.2 swifts per 100 acres); total clover acreage increased between 1909 and 1957. In other habitats, densities (all census years combined) were 1.4 swifts per 100 acres in fallow fields, 1.1 in small grain, and 0.6 in corn. We do not imply by these ohservations that the swift consciously chooses particular foraging habitats. The 
distribution of foraging swifts probably reflects distribution of insect concentrations, which vary from habitat to habitat.

It is difficult to estimate population change, if any, in the chimney swift between 1909 and 1957. Population densities of this species in urban areas, perhaps the best guide, were 6.0 birds per 100 acres in the southern zone in 1909 and 24.4 in the same zone in 1958. Ecological changes since 1909 appear to be highly favorable to the chimney swift. With increased nesting habitat arising through urbanization, and an increase in favored foraging habitats, the swift population may increase along with the human population.

Yellow-Shafted Flicker. - Of the seven species of woodpeckers (yellowshafted flicker; pileated, red-bellied, redheaded, hairy, and downy woodpeckers; and yellow-bellied sapsucker) found within the census strips (all years included), the flicker was the most abundant. It was counted in all zones and years, both summer and winter.

The yellow-shafted flicker was found in a yreat variety of summer habitats, and in all of them population densities were consistently (all census years) highest in the northern zone. Densities were slightly lower in the central zone than in the northern and fell off sharply in the southern. For example, in 1909, pastureland had 16.6 flickers per 100 acres in the northern zone, 14.9 in the central zone, but only +.3 in the southern.

Favored summer habitats of the flicker were hedgerows, savanna-type areas, edge shrubbery, residential areas, and forest. Densities of flicker populations in various summer habitats in northern Illinois in 1957-1958 were $31 .+$ birds per 100 acres in hedgerows, 21.6 in savanna-type areas, 8.4 in edge shrubbery, 5.6 in residential areas (27.8 in 1909), 5.6 in forest, 3.0 in shrub-grown areas, 2.9 in pastures (16.6 in 1909), 2.2 in mixed hay (6.8 in 1909), 2.1 in fallow fields (20.6 in 1909), 1.2 in oat fields (1.2 in 1909), 1.0 in ungrazed grassland (6.8 in 1909), and 0.8 in cornfields (2.8 in 1909). (No surveys were made in northern Illinois in 1907.) Harvested hayfields and clover fields, which often have high bird populations, were apparently not attractive to fickers. In all habitats for which we have comparative data over the entire state, population densities of the flicker were much lower in 1957-1958 than in 1907-1909.

As the density data imply, the state flicker population declined greatly between the two study periods, from about $2,279,000$ birds in 1909 to 300,000 in 1957 and 225,000 in 1958. Perhaps 1909 was a bumper year for flickers. The population was lower in 1907 than in 1909; yet the central and southern zones in 1907 (no census in the northern zone that year) had about 727,000 flickers, more than twice the 1957 or the 1958 population for the entire state.

Causes for the decline in flicker numbers can only be surmised. Habitat changes probably had some effect. The flicker is not strictly a forest bird. Open fields, particularly grassland, and scattered trees for nesting sites are probably the essential habitat requirements. While Illinois contained more forest in 1957-1958 than in 1907-1909, savanna-type situations in the state probably were greatly reduced; tree removal from field edges and tillable land has recently been common practice in Illinois. Reduction of pasture acreage eliminated some nesting sites (scattered trees), as well as good foraging habitat.

The introduction of the starling may have played a very important role in reducing the flicker population. Competition amone certain species for nest cavities is keen, and starlings have proved their ability to compete. Of all the Illinois picids, the flicker has been most closely associated with man and is therefore probably most in competition with the introduced bird. In the summers of 1957 and 1958, flicker populations varied from place to place in urban areas inversely with the starling populations. The change in the flicker population between 1909 and 1957 accentuated its north-south cline. The northern zone of Illinois had about 841 ,000 birds in 1909 and 186,000 in 1957 ; the southern zone had $+45,000$ in 1909 and less than 15,000 in 1957.

In winter, most of the Illinois flicker population was found in the southern zone. In contrast to the summer population densities, winter densities were not consistently lower in 1956-1958 than in 1906-07. 
In 1906-07, the picked cornfields with stalks still standing comprised the favorite winter habitat of the flicker, as well as many other species, in southern lllinois; no other habitat boasted such a high density (7.7 flickers per 100 acres in contrast to 1.7 for corn stubble only). Other favored habitats were shrub areas, ungrazed grassland, forest, and pasture. Flicker population densities for these and other winter habitats in the southern zone for 1956-1958 were 6.0 flickers per 100 acres in hayfields ( 1.0 for 1906-07), 4.6 in shrub-grown areas, 3.8 in forest (2.5 for 1906-07), 2.2 in ungrazed grassland (6.6 for 1906-07), 2.0 in pasture (2.9 for 1906-07), and 2.0 in mechanically picked cornfields (for 1906-07, 1.7 in stubble and 7.7 in hand-picked fields). The cornstalk habitat, by its attractiveness and almost unlimited availability, may have been partly responsible for low densities of the flicker in other habitats in 1906-07. Winter wheat, an ample habitat in southern Illinois, apparently was not used by the flicker, nor were fields of small grain stubble to any considerable degree.

In January, 1907, there were about $5+4,000$ flickers wintering in the state ( 75 per cent in the southern zone). In January, 1957, the state flicker population numbered about 202,000 birds ( 85 per cent in the southern zone). As in populations of some other species, flicker populations apparently shifted southward in late winter, for in February, 1958, about 394,000 birds (96 per cent of the state population) were in the southern zone and less than 20,000 in the rest of the state.

Red-Bellied Woodpecker.-In 1907-1909, the breeding population of the red-bellied woodpecker in Illinois was virtually restricted to the southern zone, but, in 1956-1958, this species was found in all zones of the state.

The primary habitat for the red-bellied woodpecker was forest, in which summer populations were remarkably constant at about 5 birds per 100 acres in the southern zone in both the early and later census years. By 1957-1958, the central zone forests also had attained densities of about 5 birds per 100 acres, but the nesting population in the northern zone was still very sparse. Because population densities of the red-belly appeared to level off at 5 birds per 100 acres in both the southern and central zones, we belicve that this figure represents a saturation level for the breeding population in this species.

Other habitats frequented by the redbelly in summer were shrub areas and grassland, especially pasture, which were probably foraging areas (usual densities: about 2 birds per 100 acres in each of these habitats).

In the winters of 1956-57 and 195758 , the red-bellied woodpecker populations in forest increased over the summer levels in all zones of the state. From the summer density of 5 birds per 100 acres, the forest population increased by winter to 9 birds per 100 acres in the southern zone and 7 per 100 acres in the central zone. Because the red-bellied woodpecker is not a strongly migratory species, much of the winter increment probably represented local production. Both the geographical distribution (extension of the range northward) and the ecological distribution of the red-bellied woodpecker were greater in winter than in summer. Evidence of a northward extension of the population in winter was the fact that the forest population in the northern zone increased from a very sparse population in summer to about 3 birds per 100 acres in winter. Ecological extension was evident in winter when the red-belly was seen in shrub areas, fallow fields, pastures, and even row crops. Winter densities in nonforest habitats were usually 1 to 2 birds per 100 acres. The ecological extension may have represented both a wandering juvenile population and a seasonal change in foraging habits by the total population.

We estimate that the breeding population numbered about 103,000 in 1907 and 119,000 in 1909 , all in the southern zone. By 1957-1958, the number of redbellies in the state had greatly increased (to at least 198,000 in 1957 and 153,000 in 1958), with most of the population in the southern and central zones. The population will probably continue to increase in the northern zone. Because the redbellied woodpecker is a forest species (not associated with man), it is less in competition with the starling than is the flicker.

Red-Headed Woodpecker.-In all census years, the red-headed wondpecker 
was encountered throughout the state in summer, but only in the southern and central zones in winter. In 1907-1909, summer populations of the red-head were fairly uniformly distributed in the state, but, in 1957-1958, the southern zone had a negligible part of the state population. Populations of this species are notoriously variable from vear to vear, but, even after considering this annual variation, we believe that the red-headed woodpecker population was much higher in 1907-1909 than in the later census years.

Like the flicker, the red-headed woodpecker appeared to prefer a savanna-like situation in summer; it was found often in open fields. Favored summer habitats, in addition to savanna-type, were shrubgrown areas and forest. 'The red-headed woodpecker was found in virtually every habitat censused in 1907-1909. but in only a few habitats in 1957-1958. Densities of red-headed woodpecker populations in various habitats in the state in 1907-1909 were 22.1 birds per 100 acres in shrubgrown areas (1.t in 1957-1958), 12.8 in forest (2.3 in 1957-1958), 5.8 in orchards, 3.8 in fallow fields, 3.7 in red clover $(0.7$ in $1957-1958), 3.6$ in pastures (0.2 in 1957-1958), 3.5 in ungrazed grassland $(2.1$ in 1957-1958), 2.7 in plowed fields, 1.8 in residential habitat (0.6 in $1957-1958), 1.5$ in wheat, 1.2 in mixed hay, 1.1 in corn (0.1 in 1957$1958)$, and 0.4 in oats. Savanna-like areas censused in 1957-1958 had 16.0 redheaded woodpeckers per 100 acres.

The summer populations of the redheaded woodpecker in 1957-1958 were but a small fraction of those in 19071909. We estimated that there were about $1,270,000$ red-headed woodpeckers (breeding adults) in the state in June, 1909. but onlv 115,000 in 1957 and $13+, 000$ in 1958. The 1907 population may have been under 1 million (no northern zone census in 1907), but it was still at least seven times as great as the 1957-1958 populations. The red-head and the flicker had a similar pattern of gross population reduction in the state, a reduction that was especially noticeable in the southern zone. These two species have certain habitat preferences in common: in summer, thev, more than other species of woodpeckers, seek nonforest habitats. The in- troduction of the starling and some subtle, though important, habitat changes discussed in the section on the ficker have probably had harmful effects.

The red-headed woodpecker is migratory and in winter it usually vacates the northern parts of its breeding range. In winter, forest becomes the primary habitat almost to the exclusion of other habitat types. The red-headed woodpecker in Illinois wintered farther north in 19561958 than in 1906-07. This northward extension may represent a trend, though the winter distribution of red-heads varies greatly from time to time and depends on availability of acorns and on other foraging conditions. In 1906-07, despite the mildness of the winter, redheads were found in Illinois only in the southern zone, where the population numbered only 38,000 birds, mostly in forest. By contrast with the flicker, the red-head made little use of cornstalk habitat. In 1956-1958, red-headed woodpeckers were found in forest in both the central and southern zones, and state populations numberd 92,000 (72 per cent in the southern zone) in January, 1957, and $42+, 000$ (98 per cent in the southern zone) in February, 1958. The very high winter population in the southern zone in 1958 probably represented a special concentration, the result of unusually good foraging conditions there. The central zone was virtually devoid of red-heads, and part of the concentration in the southern zone may have come from states adjacent to Illinois.

What the future holds for this species is difficult to predict. There is some evidence that red-head populations reached their lowest level before 1957 (but after 1909) and that the populations have come back slightly in recent years. With competition for nesting cavities particularly great since the introduction of the starling, a notable future increase in the redhead population seems unlikely.

Downy Woodpecker.-The downy woodpecker was encountered throughout the state during the surveys about four times as frequently, both in summer and winter, as its congener, the hairy woodpecker.

The downy woodpecker is primarily a forest species, and we can say little about 
population changes, if any; between 1909 and 1957, because of the small acreage of forest sampled in summer in the earlv surveys. Our southern census samples indicate that the state population of the downy increased at least slightly between the two survey periods, perhaps because of the spread of forest.

The geographic and ecological distribution of the downy woodpecker in the recent surveys is of interest. In the summers 1957 and 1958, downies were found in the northern and central zones only in forest, but in the southern zone in both forest and shrub areas. Population densities indicated that central zone forests were particularly good for downies. Forest populations were 3.4 hirds per 100 acres in the northern zone, 12.2 in the central, and 2.8 in the southern.

We estimated that the state breeding population of the downy was about 287 ,000 in 1957 and 219.000 in 1958. (Estimates of forest populations are apt to be low if based on the strip census method.) In both years, 53 per cent of the nesting population of the state was in the southern zone and about 40 per cent in the central.

The downy woodpecker is supposedly. not a migratory species in Illinois. In winter, the downv population, swelled bv summer production, extended into many nonforest habitats, our data showed. This ecological extension may be explained by one or more of the following: the natural overflow of a swelled population, the wandering of juveniles, or a change (from summer) in foraging habits by the total populace. IVoody habitats (forest, shrubs, and orchards) had the highest population densities in winter: such open-field habitats as corn stubble, fallow fields, and pasture also harbored downy populations.

Winter population estimates of the downy woodpecker for the state were 322,000 birds in $1906-07,506,000$ in 1956-57, and 507,000 in 1957-58. These figures represented increases over the respective summer populations of about 2 to 1 ; the ratio was not the same in all zones. About 60 per cent of the state population was in the southern zone, only 10-15 per cent in the central zone, and 25-30 per cent in the northern zone. These figures mean that winter populations in the northern and southern zones increased greatly over their respective summer populations, as expected, while the winter population in the central zone actually fell below the summer population there. 'The distribution pattern is exceedingly perplexing, but, because the pattern was consistent in all census years, we feel that it represents a genuine biological phenomenon. The data suggest that there is at least one migratory population of downies in the state; distribution, both winter and summer, in this species needs careful and detailed study.

With increased acreage of forest, and almost unlimited areas of winter forage habitats (corn, fallow fields, pasture, shrub, and forest), the future for this species looks bright.

Eastern Kingbird. - Six species of summer resident flycatchers (eastern kingbird, crested flycatcher, phoebe, Acadian flycatcher, Traill's flycatcher, and wood pewee) were encountered during the summer surveys. The eastern kingbird was fairly uniformly distributed in the three zones of the state in 1907-1909, but populations tended (all census years) to be most dense in the northern zone, least dense in the southern. For example, pastureland in 1907-1909 had 4.7 kingbirds per 100 acres in the northern zone (5.7 in 1957-1958), 3.t in the central (1.7 in 1957-1958), and 2.5 in the southern $(0.0$ in 1957-1958). Populations in the southern zone were particularly low in the recent census years. In 1957-1958, shruhgrown areas had densities of 9.3 kingbirds per 100 acres in the northern zone, 8.2 in the central, and $0 . S$ in the southern.

The eastern kingbird occurred in all census years in virtually every summer habitat censused; particularly favored were edge shrubhery, farmyards, shrubgrown areas, savanna-type areas, and orchards. Densities of kingbird populations in various habitats in the northern zone in 1957-1958 were 33.5 birds per 100 acres in edge shrubs, 9.3 in shrub-grown areas, 7.2 in savanna-type areas, 6.2 in fallow fields, 5.7 in pasture ( 4.7 in 1909 ), 1.8 in red clover, 1.4 in both mixed hav and mowed hayfields (2.8 in 1909), and 0.3 in cornfields (1.7 in 1909). In 19071909 , farmyards of the state had 7.3 kingbirds per 100 acres: orchards in the southern zone had 6.6 per 100 acres (3.8 in 
1957-1958). Frequently used (all census years) foraging habitats in the central and southern zones were plowed fields (2.5 birds per 100 acres), oat fields (1.6), and ungrazed grassland (1.4). Population densities in favorite habitats were roughly similar in 1907-1909 and 1957-1958, but densities in marginal habitats, such as cornfields, indicated that there had been a decline in the kingbird population between 1909 and 1957.

Our estimates of the state breeding populations of this species were 662,000 in 1909 (about 650,000 in 1907, estimated from central and southern populations), 307,000 in 1957, and 226,000 in 1958. The decline was particularly striking in the southern zone, where the kingbird population fell from about 350,000 birds in 1907-1909 to less than 100,000 in 1957-1958.

Because the tyrant flycatchers are notably aggressive in competing with other species, competition would seem an unlikely factor in the decline of the kingbird. Habitat changes between 1909 and 1957 probably had a marked effect on the kingbird population. Areas of two important kingbird habitats, orchards and pastureland, were reduced tremendously. An increase in forest areas probably eliminated some kingbird habitat, and reduction in the numbers of farmsteads and hedgerows in recent years removed some prime nesting habitat. It is possible that changes in the insect fauna had an effect on the kingbird population. The fact that the 19571958 densities in orchards were notably below the 1907-1909 level suggests that modern methods of orchard management do not favor the kingbird. Because roadside vegetation (hedges and shrubs) provides an important habitat for kingbirds, roadside spraying with herbicides and insecticides may have played an important role in the decline.

Horned Lark.-In all census years. the horned lark was recorded throughout the state, both summer and winter, in all open-field habitats. Summer population densities for the lark were notably lower (all census years) in the southern zone than in the central and northern zones. For example, cornfields in 1957-1958 had 32.9 larks per 100 acres in the northern zone and 32.2 in the central zone, but only 4.7 per 100 acres in the southern zone. In certain habitats, particularly hav types, there was marked difference between northern and central zone populations. In 1957-1958, population densities in alfalfa fields were 112.9 larks per 100 acres in the central zone and 11.6 in the northern; densities in red clover fields were 96.8 in the central zone and 0.4 in the northern.

Densities of horned lark populations in various summer habitats in the central zone in 1957-1958 were 149.8 birds per 100 acres in plowed fields, 112.9 in alfalfa, 96.8 in red clover, +6.6 in soybeans, 32.2 in cornfields (6.6 in 1907-1909), 31.9 in sweet clover, 24.2 in small grain stubble, 11.t in oat fields (5.0 in 19071909), 6.0 in ungrazed grassland, 5.5 in fallow fields, 4.1 in pastures (5.4 in 1907 1909 ), and 3.4 in mixed hay (0.8 in 1907-1909). In the northern zone in 1957-1958, sand prairie had 130.5 larks per 100 acres.

No Illinois species increased more dramatically between 1909 and 1957 than the horned lark. Besides the population increase, there was an apparent change in the habitat of the lark between the two census periods; this habitat change had great bearing on the population increase. The change was probably in progress even in 1907-1909, when the lark was much more of a grassland species than in the later census years. While the statewide population increased enormously, densities in pastureland actually decreased after 1909. From the natural grassland situation, the lark has moved in increasing numbers to cultivated habitats (corn, soybeans, and hay legumes), most of them associated with row-crop agriculture. This move was from a diminishing to an expanding habitat. Modern land management seems almost specifically designed to favor the lark. The row-crop acreage is excellent lark habitat in spring and early summer, but in midsummer, as the crops grow, this acreage loses its attractiveness to the lark. Harvesting of hay and small grain in midsummer opens up a vast new acreage, and the lark population shifts to the cut fields. In the northern zone in 1957-1958, mowed hayfields had 37.t larks per 100 acres, a density about comparable to that in row crops in early June. 
The modern practice of mowing roadsides also favors the lark.

In June, 1909, the statewide population of the horned lark was estimated to be about $8+2.000$ birds, most of them in the northern ( 46 per cent) and central (38 per cent) zones. The 1907 statewide summer population was higher, but probably numbered less than 1.500,000 larks (no census in northern zone). In June, 1957, the state population of larks numbered about 5,621,000 birds and, in June, 1958, $+,+77,000$.

As in 1907-1909, most of the horned lark population in 1957-1958 ( $85-90$ per cent) was in the northern and central zones, but the center of abundance had shifted southward to the central zone. The June counts did not represent strictly the breeding populace. We did not include identifiable juveniles in our population calculations, but, as horned larks nest early in spring, some well-grown juveniles were probably counted as adults. Inclusion of some juveniles in the counts was probably a source of some of the year-to-year variation noted above. Early spring (February-March) temperatures were above normal in 1957, but abnormally low in 1958. Nesting was probably delayed in 1958, and the count for that year may have included few juveniles. The entire winter and early spring of 1908-09 had above-normal temperatures, and the count for June, 1909, may have had a higher proportion of juveniles than either the 1957 or the 1958 counts.

Winter habitats for the lark were the winter counterparts of the summer habitats (corn stubble or stalks, bean stubble, small grain stubble, winter wheat) and included virtually all open-field areas. In 1906-07, corn stubble, pasture, small grain stubble, and wheat, listed in order of preference, were the most favored winter habitats; in 1956-1958, bean stubble, alfalfa, and mechanically picked corn were the preferred habitats. Modern agriculture favored the lark even in winter. The cornstalk habitat (corn picked by hand and the stalks left standing), which covered much of the winter landscape in 1907-1909, was virtually unused by the lark, while the less abundant corn stubble was a favorite winter habitat of the species. Mechanized corn picking all but eliminated the standing cornstalk habitat, which farored many other species of birds in winter, and vastly increased a habitat that favors the lark.

Winter populations of the horned lark in the state numbered about $2,416,000$ birds in 1906-07, 9,175,000 in 1956-57, and $7,63+, 000$ in 1957-58. In all census years, the ratio between winter and summer populations for the state was 1.6 or 1.7 larks in January to 1.0 the following June. The constancy of this ratio is surprising; it may provide a clue to the reproductive increment in this species, but further study on the natural history of the horned lark is needed before we can understand the significance of the ratio. Although this ratio was constant from year to year, it was not constant from zone to zone. The winter-summer ratios for the different zones imply that horned lark populations in the northern part of the state shifted southward in winter. In 1956-57, for example, the northern zone had only 0.6 lark in January to 1.0 in June and the central zone had 1.3 larks in winter to 1.0 in summer; the southern zone had 6.5 larks in winter to 1.0 in summer.

At the time of the recent survey, the future outlook for the horned lark in Illinois appeared to be entirely favorable.

Barn Swallow.-Of the six species of swallows (tree, bank, rough-winged, barn, and cliff, and the purple martin) encountered in the summer surveys, the barn swallow was undoubtedly the commonest member of its family. At the time of the early series of censuses, this bird was most abundant in the northern zone and least abundant in the southern. In the 50 years that followed, this species increased in numbers, particularly in the southern zone. In 1957-1958, the barn swallow was most abundant in the southern zone, least abundant in the northern. Population densities of the barn swallow over alfalfa fields in 1957-1958 were 4.4 birds per 100 acres in the northern zone, 24.0 in the central zone, and 38.8 in the southern zone.

The barn swallow was seen foraging in summer in a great variety of open-field habitats; it favored edge shrubs, alfalfa, sweet clover, pastures, and ungrazed grasslands. Population densities for various foraging habitats of the state in 1957- 
1958 were 26.3 swallows per 100 acres over edge shrubs, 13.1 in alfalfa, 11.8 in sweet clover, 9.6 in pastures ( 1.7 in $1907-$ $1909), 7.5$ in ungrazed grasslands $(27.0$ in 1907-1909), +.2 in red clover (5.2 in $1907-1909), 4.2$ in mixed hay (3.3 in $1907-1909), 3.5$ in oats and wheat $(0.5$ in 1907-1909), 3.t in fallow fields (6.2 in 1907-1909), and 1.7 in corn and soybeans (0.2 in 1907-1909). Ungrazed grassland, fallow fields, and red clover, the favored habitats in 1907-1909, apparently lost some birds to alfalfa, a crop that increased greatly after 1909. Edge habitats, such as roadsides and drainage ditches, appeared to have high numbers of foraging barn swallows. Cutting enhanced fields of wheat and hay as foraging areas for swallows.

State population estimates for this species were 300,000 birds in June, 1909, and 910,000 in June, 1957. The 1907 population was probably even lower than 300 ,000 (no northern zone census in 1907), and the 1958 population was probably over $1,000,000$. The harn swallow is another of the species that increased greatly between the early and later surveys.

Not only did population densities of the barn swallow in some favored foraging habitats (notably pastureland) increase between the two census periods; certain habitat changes favored the barn swallow. Alfalfa, one of the hest habitats, became a dominant hay crop in Illinois, and other hay crops proved to he good foraging habitats for the barn swallow.

Barns, important nesting sites for the barn swallow, were probably less plentiful in 1957-1958 than in 1907-1909, but cement culverts and bridges were more numerous. The barn swallow may recently have made increased use of culverts and bridges for nesting sites.

The increasing use of potent insecticides may ultimately create problems in food acquisition for the barn swallow and other insectivorous birds, but land management practices in Illinois in 1958 appeared to favor the barn swallow and some other species of swallows.

Blue Jay. - The blue jay was recorded throughout the state, both summer and winter, in all census years.

In summer, the jay occurred in a variety of woody and open-field habitats and showed some interesting regional variations in habitat preference. For example, in cornfields, a marginal foraging habitat, the jay was notably more numerous in all census years in northern Illinois than in the central or southern zones. In forests, population densities of the jay were highest in the central zone, lowest in the southern; in urban residential areas, jay populations were most dense in the southern zone. In some other habitats, pastureland, for example, there was little variation in the jay population from one zone to another.

In most summer habitats for which comparative figures are available, blue jay population densities were higher in 19071909 than in 1957-1958. In 1907-1909, the most favored blue jay habitats were forests, orchards, and residential areas. In 1957-1958, the species was numerous in residential areas and in hedgerows and edge-shrub habitat (neither of the last two habitats was censused in 1907-1909). Summer population levels of the blue jay in various habitats of the state in 19571958 were 67.6 birds per 100 acres in hedgerows, 30.0 in edge shrubs, 17.7 in residential areas (11.9 in 1907-1909), 8.0 in savanna-type areas, 6.6 in forest (33.3 in 1907-1909), t.1 in orchards (20.7 in 1907-1909), 3.2 in shrub areas (16.1 in 1907-1909), 1.t in pastureland (2.5 in 1907-1909), $0 . t$ in fallow fields (2.5 in 1907-1909), and 0.3 in cornfields (1.1 in 1907-1909).

The state blue jay population declined greatly between 1909 and 1957. Our estimates of the state population were 1,300,000 in 1907 (estimate based on central and southern zone populations), 1,557,000 in $1909,+60,000$ in 1957 , and 470 ,000 in 1958. The loss was apparent in all zones, but it was particularly great in the southern zone ( $S 1$ per cent decline in southern zone, 47 per cent decline in northern and central zones).

The population decline in this species is surprising. The blue jay is a versatile species, nesting as it does in a variety of woody habitats. Forest, a favored habitat in 1907-1909, increased in acreage, but jay populations in forest had become relatively sparse by 1957. In orchards, a diminished habitat, recent jay populations were thinner than those of 1907-1909. 
The ecology of the blue jay appears to be changing. Of all its summer habitats, only residential areas appeared to have higher populations in the recent census years than in 1907-1909. In northern Illinois in 1907-1909, the bulk of the jay population was in forest, but, in 19571958, most of the population was in residential areas. The causes for this change are not apparent. Gross habitat changes since 1909 appear to have been beneficial, not harmful. The fact that the jay population thinned in favorite habitats suggests such possible causative factors as competition, reduced availability of food, or disease (in essence, reduced productivity or increased mortality). We can only suggest that further study of this species is needed.

Some blue jay populations are migratory. The jars that winter in lllinois could represent breeding populations from states to the north, resident Illinois populations, or a combination of the two population groups. In 1906-07, the winter population of jays was estimated to number 833,000 birds (compared to $1,300,000$ the following June) ; about 81 per cent of the state winter population was in the southern zone. In 1956-57 and 1957-58, the state winter populations ( 461,000 in 1956-57, 570,000 in $1957-58$ ) were slightly higher than breeding populations in the following summers, but, like the summer populations, still far below the levels of the early census vears. To determine precisely what happens in these population shifts and changes, there is need for an intensive blue jay banding program.

The principal winter habitats of the blue jay in all census years were shrub, forest, and orchard. Jays made relatively little use of open-field winter habitats in the recent census years, although in 190607 they had frequented (in sparse numbers) cornstalk habitat and pastureland. Gross changes in winter habitats do not appear to have been responsible for reducing the jay population.

Common Crow. - In summer and winter (all census years), the common crow was counted within the census strips in all zones of the state and in virtually every habitat. Crow distribution in the three zones was quite uniform, reflecting total acreage distribution; largest numbers of crows were in the southern zone, smallest in the northern, both summer and winter.

Hedgerows, orchards, and forests were the habitats with the highest population densities of crows. Populations in most habitats were higher in 1907-1909 than in 1957-1958. Densities of crow populations in various summer habitats of the state in 1957-1958 were 15.0 birds per 100 acres in hedgerows, 5.4 in forest (6.4 in 1907-1909), 3.6 in sweet clover, 2.7 in plowed fields, 2.1 in ungrazed grassland and marshland, 2.0 in edge shrubs, 1.9 in shrub-grown areas (4.7 in 1907-1909), 0.5 in pastures (2.2 in 1907-1909), and 0.5 in cornfields (1.7 in 1907-1909). In addition, in 1907-1909, crows were found in orchards ( 13.5 per 100 acres), cut and shocked wheat fields ( 8.9 per 100 acres. in contrast to 0.2 in standing wheat), red clover (2.5). fallow fields (1.8), oat fields (1.7), and mixed hay (1.2).

Like the blue jar, the crow should presumably have benefited from gross habitat changes in the half century between census periods but, like the jay, the crow apparently declined in numbers. In June, 1909, the state crow population, according to our estimate, numbered about 1 ,227,000 birds. In June of 1957 and 1958, state crow populations were, respectively, $3+2,000$ and 290,000 birds. There was no northern zone census in 1907, but crow populations in both 1907 and 1909 were well above the 1957-1958 levels.

Gross habitat changes, except possibly those that reduced food resources, probably were not the primary causes of the decline. In terms of percentage, the decline was about the same in the two corvids, the blue jay and the crow. Both species showed declines in population density in favorite habitats.

In winter, crows were distributed throughout the state in all census years, but the central zone had by far the largest part of the state population. In all census years, also, the state crow population in winter was at least two to four times as large as that in the following summer. Estimates of the state January populations were $4,805,000$ in 1907 and $1,387,000$ in 1957. In February, 1958, the crow population numbered about 443,000 , a figure implying that dispersal of the 
winter population was well along at that time of year.

Much of the difference between the winter populations and the summer populations must represent immigration of crows from breeding grounds north of lllinois.

Cornstalks, corn stubble, small grain stubble, pasture, and forest were found to be important winter habitats for the crow.

Like the summer data, the winter population figures show that crow numbers decreased between the two census periods. Furthermore, in terms of percentage change, the winter population decline matched the summer population decline almost exactly: summer, 72 per cent decline; winter, 71 per cent. Because some of the winter crow population in Illinois comes from other breeding grounds, these data imply that the decline in crow numhers occurred over a broad geographic area.

Gross changes in winter habitats between 1909 and 1956, which should have favored the crow, offer no explanation for this decline. There was more woody cover in 1956-1958 than in 1906-1909. and food was probably more abundant in recent years as use of mechanical harvesting techniques increased. The causes of the decline, whatever they were, may have been the same as those that caused a decline in the blue jay.

Chickadees.- Both species of chickadee, the black-capped and the Carolina, were recorded in summer and winter within the census strips, but nonsinging chickadees are so difficult to identify to species that we have had to combine data for the two species. Chickadees in the northern zone were undoubtedly blackcaps. The Carolina was probably the common breeding species in the southern zone. Both species occurred in the central zone, and, in winter, both may have occurred in the southern zone.

In summer, chickadees were virtually restricted to habitats with some woody cover (forest, orchard, shrubs, and, to a much lesser extent, pasture). Because forest census samples were small in 19071909 (though probably adequate in the southern zone), we shall place emphasis on the recent population data. Population densities, especially those for the black-cap in the northern zone, were remarkably similar in 1957 and 1958. In forest, the principal habitat, chickadee summer populations in 1957-1958 were 15.8 birds per 100 acres in the northern zone (blackcap), 10.3 in the central zone (both species), and 11.3 in the southern zone (Carolina). In shrub areas, summer densities were 6.2 chickadees per 100 acres in the northern zone, 8.2 in the central, and 8.7 in the southern. In edge shrub, summer densities were 16.7 per 100 acres in the northern zone and 30.0 in the southern. The data suggest that the Carolina chickadee may make greater use of shrub habitats than does the black-cap. Neither species of chickadee was reported in residential areas to a significant extent in either census period.

The available data suggest that the Carolina chickadee was more numerous in 1957-1958 than in 1907-1909. In the southern zone, the summer population of the Carolina chickadee did not number more than about 78,000 birds in 1907 1909 , according to our estimate ; chickadee populations of the southern zone numhered about 400,000 birds in 1957 and 300,000 in 1958. Even if the forest segment of the chickadee population for 1957-1958 were disregarded, the recent populations would exceed those of the early census years. Because the forest census sample for northern and central Illinois was small in 1907-1909, and because the black-cap is definitely a forest species, we cannot speculate on population trends in this species.

It is worthwhile to consider the 195\%1958 data on chickadee populations in more detail. Chickadee distribution tended to follow the distribution of woody habitats (greatest number of chickadees in the southern zone, smallest number in the northern). Far more summer habitat was available to the Carolina (in the southern zone) than to the black-cap (in the northern). The "unbalanced" habitat distribution may in part account for the higher black-cap population densities in the northern zone. We estimated that in summer the state population of chickadees (both species) numbered about 600,000 in 1957 and 460,000 in 1958 . The northern zone had only about 82,000 chickadees (black-cap) in each year, while the south- 
ern zone had about 400,000 (Carolina) in 1957 and 300,000 in 1958. The central zone had about 120,000 birds (both species) in 1957 and $S 0,000$ in 1958.

In winter (all census years) chickadees invaded a large number of habitats, including fallow fields, corn stubble, hayfields, and even bean stubble and plowed fields, but, as in summer, woody types comprised the principal habitats.

Chickadees (at least the black-cap) appeared to be somewhat migratory. From the summer population levels in 1957, the 1957-58 winter chickadee populations declined in the northern zone, remained about the same in the central zone, and doubled in the southern. Migration is implied in these data; in a nonmigratory species, we should expect that in each zone the winter population would be greater than the previous summer population.

The census data indicate that there was some change in numbers of the blackcap, or in distribution of the black-cap, between 1907 and 1956. In both 1906-07 and 1956-57, the state winter population of the chickadees (both species) numbered about 1,000,000 birds, but chickadee distribution was very different in the two years. January populations for the northern zone were 230,000 in $1906-07$ and 63.000 in 1956-57; for the central zone, 226,000 in $1906-07$ and 105,000 in 195657: and, for the southern zone, 660,000 in 1906-07 and 830,000 in 1956-57. In January, most of the chickadees in the northern and central zones must have been black-caps, and their numbers were about three times as great in 1906-07 as in the recent census winters. WVithout better summer data, we cannot say that this apparent decline represents a real change in total numbers of the black-cap; the difference between the 1906-07 and 195657 populations may represent a change in winter distribution of the hlack-cap, or merely "natural" annual variation. Additional information is needed on the distribution of both species of chickadees, particularly on their migrations.

Tufted Titmouse. - The tufted titmouse, like the chickadees, is primarily a forest species. It is virtually restricted to habitats with some woody cover. IVe have meager summer data on this species for 1907-1909, except for the population of the southern zone. In recent censuses, the tufted titmouse was found in all three zones of the state, but populations were very low in the northern zone. For example, summer population densities (1957-1958) in forests were about 20 titmice per 100 acres in the southern and central zones and only 0.6 per 100 acres in the northern zone. Southern zone populations of the titmouse in various summer habitats in 1957-1958 were 19.3 birds per 100 acres in forest (14.2 in 1907-1909), 9.t in shrub-grown areas (5.3 in 19071909), 5.1 in edge shrub and residential areas, and 1.3 in orchards (13.3 in 19071909). A density of about 20 titmice per 100 acres may represent a kind of saturation level for central and southern Illinois forests. The recent thinning of populations in orchards (despite increases in other habitats) is a pattern observable in other species, as well as the titmouse.

The tufted titmouse increased in numbers between 1909 and 1957, at least in the southern zone, where the June population was about 324,000 birds in 19071909 and 550,000 in 1957-1958. There is no reason to doubt that the population increased northward, also. In 1957-1958, there were about 200,000 titmice in the central zone and about 20,000 in the northern. Our estimates for the entire state were 752,000 titmice in 1957 and 756,000 in 1958 . If these figures are representative, they indicate that the titmouse population is one of the least variable for which we have data.

The increase in forest acreage has surely been beneficial to the titmouse, but the fact that forest populations of this species increased in density shows that other factors than habitat change entered into the population increase. Both the titmouse and the Carolina chickadee are cavity nesters. Because of their small size, they probably have little competition from the larger forest species, but they may compete with one another. The northward advance of the titmouse may have had some effect on the black-capped chickadee. The occurrence of the titmouse (but not the chickadees) in the urban residential areas censused is of ecological interest; at present this habitat accounts for only a very small fraction of the titmouse population of the state. 
Winter distribution of the tufted titmouse through the state, the surveys showed, was similar to the summer distribution. In winter, the titmouse held to the woody habitats more than did the chickadees. The tufted titmouse is not known to be migratory; yet, in both of the recent census years, the state winter population was below the following summer population. We estimated that the state population of the titmouse numbered about 670,000 birds in January, 1957 ( 750,000 the following June), and 470 ,000 in February, 1958 ( 760,000 the following June). Such a pattern of seasonal fluctuation suggests the possibility of migration. There are few other data to corroborate such a view, and we should consider other possibilities. The titmouse probably begins nesting in April, and the February census figure may represent the adult breeding population hetter than the June figure. $B_{y}$ June, many juveniles may be flying; the juvenile plumage in this species is similar to the adult plumage, and the June count may include many immatures.

Mockingbird.-In summer of all census years, the mockinghird was encountered in central and southern Illinois, but, in winter, this species was seen within the census strips only in the southern zone. The central Illinois population was almost negligible in the early census years; in 1957-1958, population densities of the mocker in central Illinois were only about one-third of the southern Illinois densities.

Principal summer habitats for the mockingbird were residential areas and orchards in 1907-1909 and edge shrubs (not censused in 1907-1909) in 1957-1958. Densities of mockingbird populations in various habitats of southern Illinois in 1957-1958 were 40.5 birds per 100 acres in edge shrubs, 2.6 in orchards (17.7 in 1907-1909), 1.0 in residential habitat (24.2 in 1907-1909), 0.8 in pastures (2.7 in 1907-1909), 0.8 in shrub-grown areas (2.7 in 1907-1909), and $0 .+$ in cornfields (2.5 in 1907-1909). In addition, in 19071909. fallow fields had $t .1$ mockers per 100 acres, and plowed fields had 2.2 per 100 acres.

The density data indicate a decline in the state mockingbird populations between 1909 and 1957. Our estimates of summer populations in the southern zone were 184,000 in $1907,386,000$ in $1909,89,000$ in 1957, and 54,000 in 1958 (the 19071909 figures do not include edge shrub, but the 1957-1958 figures do). While mockingbird numbers for the state and for the southern zone diminished hetween 1909 and 1957, the numbers for the central zone increased notably. In the summers of 1907-1909, there were probably fewer than 5,000 mockers in the central zone, but northward extension brought the number in this zone to about 31,000 hirds in 1957. The number was down in 1958 (perhaps as low as 15,000 ), hut it still far exceeded the 1907-1909 level. Even with the geographically extended population, the total number of mockingbirds in the state in $1957(120,000)$ was helow the 1907 figure (more than 184,000 ). The combination of geographic extension and thinning population can be observed in a few other species, for example the turkey vulture. Why the mockingbird population thinned in the southern zone we cannot say. Except for orchards and pastureland, mockingbird habitats should have been nearly as extensive in 1957-1958 as in 1907-1909. The species now seems overly dependent on one type of habitat, edge shrubs, a habitat that is being eliminated by modern farming practices. A hopeful development is the increase in recent years of multiflora rose hedges, which are much favored by the mockingbird.

By winter each year, the mockingbird population has shifted southward in Illinois, and, though a few birds may winter in the central zone of the state, the species was recorded within winter census strips in 1906-07, 1956-57, and 195758 only in the southern zone, in habitats that were the winter counterparts of the summer habitats. The mockingbird populations in Illinois numbered about 63,000 birds in January, 1907, and 39.000 in January, 1957. The population level in February, 1958, was much higher (187,$000)$, probably because spring migration was under way and migrants were concentrated in the latitudes of southern Illinois.

Catbird.-In all census years, the catbird was found throughout the state in summer. It occurred in a variety of habitats (urban areas, forest, orchards, shrubs, 
pastures, oats, wheat, corn, hayfields, and marsh), but in greatest densities in woody types. Population densities varied greatly from zone to zone and in no consistent pattern.

In the summers of 1957-1958, densities in forest were 2.2 catbirds per 100 acres in the northern, 7.5 in the central, and 0.3 in the southern zone; densities in residential areas were 0.6 in the northern, +.0 in the central, and 22.t in the southern zone. Catbird populations in various woody habitats in southern lllinois (the zone for which we have the hest data for both census periods) were, for 1957-1958, 22.4 birds per 100 acres in residential areas (12.1 for 1907-1909), 5.1 in edge shrubs (1+.3 for 1907-1909), 2.6 in orchards (26.5 for 1907-1909), and 0.8 in shrub-grown areas (2.0 for 1907-1909). In northern and central Illinois, the cathird (like the brown thrasher, but unlike the mockingbird) greatly favored hedgerows (1957-1958 population density: 152.7 catbirds per 100 acres). In northern Illinois, wheat fields were a favorite foraging habitat.

IVe estimated that the statewide summer population of catbirds numbered about 196,000 in 1957 and 220,000 in 1958. We lack data on the prime woody habitats in northern and central Illinois for 19071909 , but, even without the catbirds in these hahitats, the state population in 1909 numbered at least 278,000 catbirds. The 1907 population was lower (no northern zone census in 1907), but probably it was zlose to 200,000 . If we make allowance for the uncensused woody habitats, we conclude that the catbird population in the state declined considerably between 1909 and 1957.

Brown Thrasher. - Of the three mimids (mockingbird, catbird, brown thrasher) in Illinois, the brown thrasher was by far the most abundant in all census years. The thrasher occurred in summer in all zones of the state, but, in 1907 1909 , most of the state population was in the southern (especially) and central zones.

The brown thrasher was counted in all summer habitats except soybean fields, but this species particularly favored hedgerows and edge shrubs. Population densities varied from zone to zone and in fa- vorite habitats tended to be highest (all census years) in the central and southern zones. In 1957-1958, thrasher populations in hedgerows were 62.9 birds per 100 acres in the northern, 188.7 in the central, and 137.0 in the southern zone; in edge shrubs, 60.9 in the northern, 68.5 in the central, and 75.9 in the southern zone; in shruh areas, 27.8 in the northern, 12.2 in the central, and 2.t in the southern zone. In other habitats, densities tended to be more nearly uniform from one zone to another.

Densities of brown thrasher populations in various summer habitats of the state for 1957-1958 were 11.6 hirds per 100 acres in orchards (23.2 for 1907-1909), 3.6 in sweet clover, 3.5 in residential areas (23.8 for 1907-1909), 2.1 in forests (15.4 for 1907-1909), 1.6 in fallow fields (2.7 for 1907-1909), 1.0 in pastures ( 4.9 for 1907-1909), $0 . t$ in alfalfa, 0.3 in corn (1.6 for 1907-1909), 0.0 in red clover (8.0 for 1907-1909), 0.0 in mixed har (2.9 for 1907-1909). Ecologically, the thrasher was the most broadly distributed of the mimids.

As the density data imply, the brown thrasher population declined greatly between 1909 and 1957; the decline in this species was more marked than in either of the other mimids. State summer populations, according to our estimates, were about 1,558,000 thrashers in 1909 (1.172,000 in 1907 in the central and southern zones), $+31,000$ in 1957 , and 402,000 in 1958. The 1907-1909 estimates do not include birds in the high-density edgeshrub and hedge habitats; so the difference between populations in the two periods was even more marked than our figures show.

Habitat changes, such as the reduction in orchard acreage and the elimination of many hedges, undoubtedly affected brown thrasher numbers, but such changes could account for only a small part of the total population loss. As in the other Mimidae and some of the other species studied, the thrasher's population decline, though general, was particularly marked in the southern zone of the state. To explain these changes, we need to know more about the basic biology of each species. Perhaps we are seeing the mimid population and the population of some other species in a pe- 
riodic low; in the future, the numbers may increase or they may continue to decline. Whatever the trend, the need for future measurements of the populations is certainly indicated.

Robin.-Of the three thrushes (wood thrush, robin, and bluebird) recorded as nesting in Illinois in all years of the surveys, the robin was by far the most abundant.

In summer, the robin was found throughout the state in most of the habitats censused. Residential areas were clearly the favorite robin habitat in summer, at least in recent years. Orchards, edge shrubs, and hedgerows also were high density habitats. Robin populations varied from zone to zone. In 1907-1909, population densities tended to be highest in the southern zone of the state, lowest in the northern zone. In 1957-1958, densities tended to increase with north latitude. Residential areas in 1907-1909 had 27.8 robins per 100 acres in the northern, 33.5 in the central, and 36.3 in the southern zone, while, in 1957-1958, these areas had 132.2 in the northern, 108.6 in the central, and 101.9 in the southern zone.

In forest, the 1907-1909 summer densities were 6.4 robins per 100 acres in the central and 15.0 in the southern zone; the 1957-1958 summer densities were 6.1 in the central and 0.3 in the southern zone. Robin numbers apparently increased greatly in residential areas between 1909 and 1957 , but, in many other habitats, the numbers were greater in the early than in the later census years. Summer densities in various habitats of the state for 1957-1958 were 60.0 robins per 100 acres in hedgerows, 24.6 in edge shrubs, 6.6 in orchards (3+.9 for 1907-1909), 5.1 in ungrazed grassland in the northern and central zones (6.8 for 1907-1909), 1.9 in pastureland (7.3 for 1907-1909), 1.9 in shrub-grown areas (3.1 for 1907$1909), 1.8$ in mixed hay ( 1.8 for $1907-$ $1909), 1 . t$ in red clover ( +.3 for $1907-$ $1909), 0.9$ in corn ( 1.6 for 1907-1909), and 0.7 in oats (0.5 for 1907-1909).

Population densities of the robin in most summer habitats decreased between 1909 and 1957. We estimated that the state population in June numbered about $1,900,000$ robins in 1909 (in 1907 probably about $1,400,000), 1,500,000$ in 1957 , and $1,360,000$ in 1958. The geographic and ecological distribution of the robin seems to have changed. In the summers of 1907 and 1909, the robin population was fairly uniformly distributed throughout the state. Forest and pastureland accounted for the bulk of the 1907-1909 summer population, but the rohin was well represented in a variety of other habitats. It was an ecologically broad species. In 1957-1958, most (65 per cent) of the Illinois robins were in the northern zone. The robin was primarily ( 75 per cent of the state population) an inhabitant of man's communities (urban residential areas and farmyards). Reduction of pastureland probably hurt the robin, but residential areas provided the essential requirements (tree nesting sites and clipped grass foraging areas) of the pasture habitat and perhaps improved on this habitat. One possible disadvantage of this specialization in habitat is that the use of chem. icals (insecticides and herbicides) toxic to robins is especially prevalent in urban areas. Except for the possible danger from these chemicals, the future for the robin seems bright. In the coming decades, urban areas are sure to increase.

In winter, a few robins may be found even in the northern zone of the state, but, within the census transects, this species was found in only the southern zone in the winter of 1906-07 and in only the southern and central zones in the winters of 1956-1958. The primary winter habitats of the robin were picked (cornstalk) cornfields, forest, and orchards in 190607 and shrub areas, forest, and pastures in 1956-1958.

The robin may have wintered farther north in greater numbers in recent years than at the time of the early survey. In 1906-07, a notably mild winter, the Illinois robin population in January (none recorded in any zone but the southern) was probably less than 100,000 birds. The number of robins in the state in January. 1957, was estimated to be $1,366,000$ (all but 15,000 in the southern zone). This population was about the same as the June, 1958, population for the state. In February, 1958, the number of robins was down to $66+, 000$ (none recorded in the central or northern zones). Because the February population showed no north- 
ward shift, we presume that many wintering robins drifted southward in late winter before the onset of spring migration. This pattern of movement was similar to that in a number of other species.

Eastern Bluebird.-In both survey periods, the eastern bluebird was found throughout the state in summer and winter; population densities in summer tended to he highest in the southern zone and lowest in the central. In most years the southern zone had the bulk of the state population, but in 1958 the bluebird suddenly all but disappeared from southern Illinois.

Favorite summer habitats of the bluebird were edge shrubs, forest, pastures, and fallow fields, but the bluebird was found also in cornfields, plowed fields, oats, mixed hay, red clover, and marsh. Densities of bluebird populations in varjous habitats in the southern zone for 1957 were 8.3 birds per 100 acres in pastures (2.8 for 1907-1909), 2.6 in fallow fields (3.7 for 1907-1909), 1.7 in forest (6.7 for 1907-1909), 1.5 in shrub-grown areas (1.8 for 1907-1909), and 0.0 in corn (1.7 for 1907-1909). Roadside habitats are well-known favorites of the bluebird, and in 1957, along roads in southern Illinois, shruh areas had 33.6 bluebirds per 100 acres and ungrazed grass areas had 10.3 per 100 acres. Most density figures were higher in the early than in the recent surveys. A notable exception to the trend was the recent high-density figure for pastureland. The great loss in pastureland acreage between 1909 and 1957 could have had some concentrating effect on the bluehird population.

In June, 1909, the number of bluebirds in Illinois was estimated to be 460,000 ( 70 per cent in the southern zone); the population was higher in 1907 (no northern zone census), possibly as high as 600 ,000 . In June, 1957. the state had about 220,000 bluebirds ( 80 per cent in the southern zone); by the following summer the population had fallen to an almost unhelievable low of about 50,000 birds. Strangely, the northern zone population was still intact, but the central zone population was badly decimated and the southern zone population was virtually gone. We would have been inclined to doubt our census data, except that at about the same time sharp declines were noted widely by field observers in the eastern United States (James 1962:308). As of October, 1962, the Illinois bluebird population had shown only slight recovery.

In winter (all census years), the southern zone had virtually all of the bluebirds in Illinois. The birds were encountered usually in small flocks and in a variety of winter habitats. In all census years, they frequented forests, shrub areas, ungrazed grasslands, and pasture; in recent census years, alfalfa fields. The winter populations of the bluebird in Illinois were remarkably similar in the census years, numbering about 680,000 in January, 1907 and 1957, and about 720.000 in February, 1958. The number of bluebirds wintering in the northern and central zones (combined) did not exceed 25,000 birds in any census year; in February, 1958, we found no bluebirds outside the southern zone. In comparison with populations of other years, the winter population of $1957-58$ in the southern zone appeared to be about normal as late as mid-February; yet the breeding populations of the southern zone and most of the central zone never appeared. What happened to these populations remains a mystery. Diminished food resources in some areas, coupled with the enduring severe cold of January-March, 1958, would certainly have taken a toll; a number of authors have discussed weather that was harmful to the bluebird (Musselman 1941:409-10; Hancock 1888:433; and others). James (1962:310), in discussing the decline of the bluebird population in relation to weather, suggested that something other than severe weather alone was responsible for the decline.

There is evidence other than the Illinois census data that the decline in bluebird numbers has been in progress for a long time. Writing about 50 years ago, Barnes (1912:328) felt that the bluebird as a nesting bird was not one-tenth as common as 20 years before and, a few years later, Ridgway (1915:196) noted that the bluebird had been "mainly displaced" by another cavity nester, the house sparrow.

Starling.-Shortly after being introduced successfully into the United States (New York) in 1890, the starling began 
to extend its range westward. The species had not reached Illinois at the time of the first survey (1906-1909); it was evidently rare in this state in 1926 (Eifrig $1927:+32)$. Today, it is one of the most abundant species in Illinois. Both in summer and winter of 1956-1958, starlings were seen throughout the state in virtually every habitat.

In summer, we found, no other Illinois habitat was as important to the starling as urban areas, and, to a large extent, the distribution of this habitat influenced the distribution of the breeding populations of the starling in the state. Our data on population densities of the starling in different habitats suggest that there was some notable regional variation in the ecology of this bird. In the southern zone, for instance, the starling was even more decidedly an urban resident than in the northern and central zones. Urban area densities were about 120 starlings per 100 acres in the northern and central zones and 180 per 100 acres in the southern. In rural habitats, starlings in the southern zone had notable populations in orchards (30.9 per 100 acres, in contrast to 13.6 in the central zone), edge shrubs (high populations in all zones), and corn ( 8.5 per 100 acres, in contrast to 0.2 in the central zone). For central zone starlings, havfields were consistently the favored rural habitats. Starling densities in various types of hay were as follows for the central zone: 117.1 birds per 100 acres in mowed hay ( 44.0 for the northern, 0.0 for the southern), 97.9 in red clover (10.9 for the northern, 0.0 for the southern). 48.0 in alfalfa ( 4.4 for the northern, 0.0 for the southern), and 3.6 in mixed hav (0.7 for the northern, 1.7 for the southern). For starlings in the northern zone, the principal rural habitat was pastureland; densities were 17.5 starlings per 100 acres in the northern zone, 2.9 in the central, and 3.3 in the southern. Regional variations in starling ecology may be based on the timing of the breeding season (at different stages in the breeding crcle, starlings may forage in different areas). The subject deserves detailed study.

Starling populations, even in summer, were extremely variable from place to place and from year to year. This variability reflected the extreme gregariousness (especially great in winter) of the species. Our population estimates for the starling are therefore particularly rough. In 111 inois, starlings begin nesting in March and April, and by June they have some young on the wing. As the juvenile plumage is distinctive and fairly long-retained, we could segregate juveniles from adults. Our estimate of the state breeding population, 3,100,000 birds, did not include farmyard habitat, a habitat that may total nearly 200,000 acres and probably harbors a large number of starlings.

In winter, the starling was found throughout the state, but, like many other species, it was most abundant in the southern zone. In all zones, the most consistently favored winter habitat of those censused was small grain stubble. Fallow fields and shrubbery (all types) were also high density habitats in winter. We estimated that the state population of starlings in January, 1957, may have exceeded $11,000,000$ birds, over 90 per cent of them in the southern zone. We have inadequate winter data on urban areas, and, considering the extreme gregariousness of the starling in winter, we believe this estimate may be very unreliable; however, there can be no doubt that the starling is near the top of the state list of birds in terms of abundance.

Yellowthroat.-Of the 22 species of warblers encountered in the course of the surveys (all years), the yellowthroat was the most widespread, ecologically as well as geographically. The yellowthroat was found throughout Illinois in summer, but most of the state population was in the southern zone; densities tended to thin northward. Many of the warblers are primarily forest species, but the yellowthroat frequents a variety of open-field habitats.

Edge shrubs, probably the most consistently favored yellowthroat habitat, had summer population densities of 24.7 birds per 100 acres in the northern, 106.6 in the central, and 120.0 in the southern zone in 1957-1958. Southern zone population densities of the yellowthroat in various other habitats in 1957-1958 were 139.0 birds per 100 acres along drainage ditches, 91.3 in hedgerows, 84.9 in marshes (9.3 in 1907-1909), 10.9 in shrub-grown areas (26.t in 1907-1909), 5.9 in red clover, 
3.9 in orchards (6.6 in 1907-1909), 3.9 in fallow fields (2.5 in 1907-1909), 2.5 in forest (11.7 in 1907-1909), 1.7 in mixed hay (2.1 in 1907-1909), and 0.7 in wheat fields (1.0 in 1907-1909). In 1907-1909, pastures and oat fields had about 1 yellowthroat per 100 acres.

The state population of the yellowthroat appeared to change little between 1909 and 1957, either in number or distribution. IVe estimated that state (summer) populations were about 414,000 birds in 1909 (90 per cent in the southern zone), 362,000 in 1957, and 427,000 in 1958 ( 80 per cent in the southern zone, both recent census years).

House Sparrow.-First successfully introduced into the United States in New York in 1852, the house sparrow was later introduced into other states. At least four introductions were made in lllinois in the period 1868-1876 (Barrows 1889:19). By 1886, virtually the entire state of Illinois, as well as a large part of the rest of the United States, was occupied by this species. The urban areas of the country were ideal for the introduced species, and the house sparrow spread through this habitat very rapidly.

In all census summers, the densities of house sparrow populations in urban and rural Illinois were highest in the central and northern zones, lowest in the southern. In rural cropland habitats, densities were conspicuously high (all census years) in the central zone, but in urban residential areas in recent census years the northern zone had the highest populations in the state. For example, 1957-1958 populations in red clover fields were 10.9 sparrows per 100 acres in the northern zone, 51.2 in the central, and 1.2 in the southern, but, in urban residential areas, the densities were 434.8 in the northern zone, 378.3 in the central, and 271.0 in the southern.

Residential areas are probably the most important habitat for the house sparrow, but few Illinois species have a more cosmopolitan distribution. Only from forests is this sparrow largely absent. Population densities of the house sparrow in important summer habitats in the state in 1957-1958 were 373.7 hirds per 100 acres in residential areas (265.2 in 1907$1909), 195.2$ in edge shrubs, 56.4 in un- grazed (largely roadside) grassland, +6.1 in orchards (125.5 in 1907-1909), 31.8 in pastures (21.5 in 1907-1909), 22.0 in oats (9.7 in 1907-1909), 20.7 in red clover (11.7 in 1907-1909), 13.1 in alfalfa, 12.3 in mixed hay (16.7 in 1907-1909), 4.8 in corn (4.6 in 1907-1909), 4.2 in soybeans, 3.4 in fallow fields (32.2 in $1907-1909), 3.2$ in wheat (29.5 in 19071909 ), and 0.1 in forest (2.2 in 19071909).

In most summer habitats, population densities of the house sparrow in recent census years were higher than those in 1907-1909. Notable exceptions were orchard, fallow fields, and wheat. House sparrow populations in most habitats declined in the southern and increased in the northern zones, and both the density increase of house sparrow populations in oats (a northern zone crop) and the decrease in wheat (a southern zone crop) were probably related to a general northward shift in the population. Despite population increases of the house sparrow in certain habitats, the statewide populations of 1957-1958 were not much greater than that of 1909 . We estimated that the state June populations of house sparrows numbered about $5,300,000$ birds in 1909 (probably about the same in 1907), 6,150,000 in 1957 , and $5,500,000$ in 1958 . The number of immatures in these populations is unknown. Urban populations of house sparrows were much greater in 1957-1958 than in 1907-1909, but rural populations, particularly in the southern zone, probably were lower; so the net change for the whole state was not great.

Rand (1956:69-70) and others pointed out the probable importance of domestic livestock in the ecology of the house sparrow and suggested that house sparrow populations in cities declined in recent decades because of the disappearance of horses from the streets. Rand also noted that sparrow populations were more dense in suburban areas than in the business districts of a large city. Obviously, some prime sparrow habitat is being lost as residential areas near the center of the city give way to the business district, but the net change is toward great expansion of good sparrow habitat. The Illinois population of house sparrows will almost certainly increase in the coming decades. 
House sparrow populations in openfield habitats (all census years) declined from an average of about 18 per 100 acres in summer to about 3 in winter. Winter brought no conspicuous increase in sparrow numbers in shrub or forest habitat; most of the sparrow population wintered in farmyards and urban areas. 'There is a parallel situation in the introduced mammal, the house mouse, which in spring expands its habitat to open fields and withdraws in fall and winter to human habitations. Because we had inadequate data for residential habitats in winter, we could not estimate the state populations of the house sparrow for this season.

Bobolink.-In the summer surveys (all years), the bobolink was encountered in both northern and central Illinois, but most of the state population was in the northern zone. Though the principal summer habitats, hayfields (all types), oats, pastures, and ungrazed grassland, were well represented in the central zone, population densities of the bobolink in this zone were consistently below those in the northern. In mixed hay, for example, there were about 60 bobolinks per 100 acres in northern Illinois, but only 11 in the central zone. Population densities of the bobolink in various summer habitats of the northern zone in 1957-1958 were 62.1 birds per 100 acres in mixed hay (53.1 in 1909), 52.9 in oats (3.7 in 1909), H.3 in alfalfa, 38.1 in red clover (18.0 in 1909), 13.6 in pastures (5.2 in 1909), and 5.2 in ungrazed grassland (5t.1 in 1909). The relatively dry margins of marshes were probably a favored habitat in 1909 (88 bobolinks per 100 acres). The apparent increased use of oat fields by the bobolink (a change that can be seen in other prairie species) helped to balance the loss in acreage of ungrazed grassland (a favored boholink habitat in 1907-1909) and pastureland.

We estimated that the June populations of bobolinks in lllinois were 1,175,000 birds in $1909,1,860,000 \mathrm{in} \mathrm{1957, \text {and }}$ $1,360,000$ in 1958. In the central zone, the population increased from less than 15,000 birds in 1909 to more than 100,000 in 1957-1958. 'The statewide increase fits a pattern of population increase and range extension that is observable in several species of open-field Icteridae.
Meadowlarks. - In all census years, meadowlarks were encountered throughout the state in both summer and winter, but, because of difficulty in determining the species of nonsinging meadowlarks, we do not know the relative proportions of the eastern and western species. Our datit represent both species, at least in the northern and central zones. All meadowlarks in the southern zone in summer, ats far as we could determine, were of the eastern species. Though specimens were taken in Illinois at least as early as 1876 (Allen $1880: 5+$ ), the western meadowlark was not sufficiently common to be recorded in the 1907-1909 surveys. In the past 50 years the western meadowlark has greatly. extended its range and is now common in both the northern and central zones of Illinois.

In most summer habitats, meadowlark populations were more dense in the southern than in the northern zone (all census years); after 1909 , populations in the northern zone increased in most habitats. For example, in red clover fields, population densities were, for the northern zone, 29.0 meadowlarks per 100 acres in 1957 1958 (9.0 in 1909); for the central zone, +7.8 in 1957-1958 (17.1 in 1907-1909); and, for the southern zone, +9.7 in 19571958 (39.5 in 1907-1909). 'The fact that meadowlark populations in the northern zone increased suggests that the western meadowlark may have been the species that particularly increased in numbers. In a few habitats, meadowlark populations in the southern zone decreased between 1909 and 1957. In ungrazed grasslands or prairie, for instance, meadowlark populations in the southern zone declined from about 63 birds per 100 acres in 1907-1909 to 50 per 100 acres in 1957-1958, even though in the northern zone populations increased from about +7 birds per 100 acres in 1909 to 80 per 100 acres in 1957-1958.

Though the meadowlarks were found (all census years) in all habitats except urban, the most important meadowlark habitats were grasslands and hayfields of all kinds. Summer population densities of the meadowlarks in various habitats of the state in 1957-1958 were 58.0 birds per 100 acres in ungrazed grasslands (63.t in 1907-1909), +8.2 in sweet clover, +4.2 in 
alfalfa, +3.2 in mixed hay $(+4.8$ in $1907-$ 1909), +2.1 in pasture (23.5 in 1907$1909)$, +1.1 in red clover (30.9 in 19071909), 20.0 in edge shrubs, 17.9 in fallow fields $(45.7$ in $1907-1909), 8.0$ in oats (6.3 in 1907-1909), 7.1 in marsh (10.t in $1907-1909), 5.8$ in orchards (15.t in $1907-1909)$, t. 2 in wheat $(9.8$ in $1907-$ 1909), 2.7 in corn (1.9 in 1907-1909), and 2.3 in soybeans.

Meadowlark population densities in the several hay crops varied considerably from summer to summer (from as low as 20 birds per 100 acres in one year to as high as 50 the next year in a given crop, such as red clover), but the total number of meadowlarks in all hay crops combined tended to remain fairly constant from summer to summer. These data suggest that in the meadowlarks there may be considerable switching of habitat from one year to the next. In some places, in hay crops of the northern zone, particularly, the density of the meadowlark population in a given crop appeared to vary inversely with density of the redwinged hlackbird population. We suspect that the meadowlarks and the redwing were reacting to something in the environment other than each other, but the relationship hetween them needs to be studied along with their specific habitat preferences.

The state population of the meadowlarks in June, hy our estimates, numbered $+, 760,000$ in 1909 ; in 1907 , the population may have been as low as $3,200,000$. The estimates for both 1957 and 1958 were $3,800,000$. The size of the state population may not have changed greatly between census periods, but the distribution of the population changed considerahly. In June, 1909, there were only about 680,000 meadowlarks in the northern zone of the state, in contrast to 1,100 ,000 in both 1957 and 1958. The southern zone had about $2,000,000$ in $1907,3,100$,()00 in $1909,1,900,000$ in 1957 , and 1 ,600,000 in 1958 . The data suggest that the northern population of meadowlarks increased and that the southern population may have declined somewhat.

By winter in all census years, the meadowlark population had shifted southward, and the bulk of the state population was in the southern zone. Favorite winter hahitats of the meadowlarks were hand- picked (cornstalk) cornfields (1906-0T only), hayfields of various types, small grain stubble, and mechanically picked cornfields (1956-1958 only).

In 1906-07 particularly, the northern and the central zones of 1 llinois had almost negligible wintering populations of meadowlarks (probably fewer than 10,$000)$. In the recent census years, meadowlarks wintered farther north in larger numbers; in January, 1957, there were probably about 300,000 in the northern and central zones combined. By our estimates, the southern zone had January populations of ahout $3,100,000$ meadowlarks in 1907 and 3,400,000 in 1957. Like a number of other species, in late winter the meadowlarks probably move farther to the south before they move north to their breeding grounds. In February, 1958, the central and northern zones probably had fewer than 10,000 meadowlarks, and the population in the southern zone was down to $1,+00,000$ birds, concentrated primarily in hayfields that provided good cover.

Redwinged Blackbird.-Few species have undergone a more spectacular population increase since the turn of the century than the redwinged blackbird. 'The redwing was common even in 1907-1909, and the species was recorded throughout the state in all census years. In summer, densities of redwing populations varied from zone to zone and in most habitats were highest in the northern zone (all census years). In 1957-1958, densities in mixed hay decreased from north to south (northern zone: 198.7 redwings per 100 acres; central : 87.4 ; southern: 53.1 ).

The redwinged blackbird was observed in a variety of summer habitats (all census years) including marshes, drainage ditches, all types of hay crops, all types of grassland, fallow fields, oats, wheat, corn, soybeans, plowed ground, shrubbery of all types, orchards, and forest; marsh, edge shrub, sweet clover, and mixed hay were notable favorites. 'The redwing was primarily a marsh species originally; even in 1957-1958, population densities were higher in marshland than in any other major habitat. Long before the first surveys, marshland was a disappearing habitat in Illinois, and the redwing in this state has made greater and greater use of 
cultivated lands. Between 1907-1909 and 1957-1958, while marshland acreage in lllinois dwindled from about 600,000 acres to 60,000 , population densities of the redwing in mixed hay increased from about 14 per 100 acres to over 130 .

Summer population densities of the redwing in important habitats of the state in 1957-1958 were 300.8 in marshes (309.8 in 1907-1909), 341.7 in edge shrubs, 203.6 in sweet clover, 158.0 along drainage ditches, $13+.3$ in mixed hay (1+.1 in 1907-1909), 88.5 in red clover (16.1 in 1907-1909), $6+.5$ in oat fields (3.9 in 1907-1909), 63.7 in ungrazed grasslands $(+7.6$ in 1907-1909), 57.8 in alfalfa, 30.1 in wheat (6.5 in 1907-1909), 26.5 in fallow fields (3.3 in 1907-1909), 23.5 in pastureland (6.0 in 1907-1909), 23.0 in shrub-grown areas, 4.6 in cornfields (1.6 in 1907-1909), and 3.3 in soybeans.

In June, 1909, there were, by our estimate, about 5,100,000 redwinged blackhirds in the state; the 1907 population may have been as low as $4,000,000$. In June, 1957, the state population numbered about $8,+00,000$ and, in June of the following year, over $11,000,000$. In 19071909 , the distribution of the state redwing population followed the distribution of marshland (high in the northern zone, low in the southern zone); marsh habitat accounted for about 60 per cent of the state population. In 1909 , in the southern zone, where marshes were least abundant, the redwing population (about 700,000 birds, in contrast to $2,+00,000$ in the northern zone) was already largely in cultivated habitats. In 1957-1958, marshes accounted for less than 3 per cent of the state redwing population, and the species had become more uniformly distributed in the state.

The redwing is an example of a species that has adapted to a changing environment. While hayfield populations of the redwing have not attained such high densities as marsh populations, the hayfields in recent years accounted for most of the state population. Although havfields are the most important nesting habitats, the great increase of redwings in oat and wheat fields should be noted. Small grain tields have been only marginal nestin: habitats, but they are probably important foraging habitats. Redwing populations in the state are probably still expanding, and efforts to control "blackbirds" because of their depredations on grain are expected to increalse.

The redwinged blackbird was not recorded anywhere in the state in the winter survey of 1906-07. In the recent census years, the winter redwing populations in the northern and central zones of Illinoi: were all hut negligible (fewer than 10,000 birds) ; in the southern zone, the species was common but it was spottily distrihuted. Favored winter habitats were cornfields, shrubhery of all types, and pasture. In January, 1957, we estimated, there were about 5,200,000 redwings in the southern zone. This great increase in the wintering population reflected the general increase, already noted, and prohably. also a tendency in the species (as noted in other species) to extend its winter range northward. The great disparity in redwing numbers between the southern zone and the central and northern zones implies that the winter range of the redwinged blackbird cannot expand much north of 39 degrees latitude without a change in climate.

Orchard Oriole.-The orchard oriole was found throughout the state in summer (all census years), but it was sighted four times as frequently in the southern as in the central zone and was least common in the northern zone. During the course of the censuses, this species was found in pastureland, fallow fields, mixed hay, red clover, wheat fields, cornfields, and forest, besides the favorite habitats: orchards, shrubbery of all types, and (in 19071909) residential areas. Because the 1907-1909 samples of woody habitats for the northern and central zones were particularly small, we placed emphasis on data from the southern zone in considering population changes in this species.

Densities of orchard oriole populations in various habitats in the southern zone in 1907-1909 were t2.0 birds per 100 acres in orchards $(1.3$ in 1957-1958), 18.1 in residential areas, 10.0 in shrubgrown areas (7.1 in 1957-1958), 3.6 in pastures (2.5 in 1957-1958), 2.8 in fallow fields (0.t in 1957-1958), and 1.5 in mixed hay. Hedgerows and edge shrubs, for which we have no 1907-1909 data, were probably the best orchard oriole hab- 
itats in 1957-1958, with densities of about 20 orioles per 100 acres in the southern zone. In 1957-1958, red clover (3.5 orioles per 100 acres) was a favored foraging habitat in the southern zone.

()rchard oriole populations were probably never very wreat in the northern or ceintral zones. In those zones, by our estimate, there were at least 50,000 orchard orioles in marginal (nomwoody) habitats in Junc, 1909, but less than 25,000 in all habitats in 1957 and 1958. June populations of orchard orioles in the southern zone numbered about 375,000 birds in 1907, +15,000 in 1909, 97,000 in 1957, and 65,000 in 1958 . Habitat changes, the wreat losses in orchard acreage particularly, had much to do with the decline in the oriole population, but other factors than acreage changes must have been involved in the population decline. 'The orchard oriole was apparently much more common in residential areas in 1907-1909 than in recent years. Also, oriole population densities in orchards declined greatly hetween 1909 and 1957. Some qualitative characteristics of these prime oriole habitats must have changed, and these changes, in turn, had a serious effect on the oriole population. The changing orchard oriole population is another of the ornithological problems that need further study.

Common Grackle.-During the course of the censuses (all years), the grackle was encountered commonly in summer throughout the state but only once in the winter season (southern zone). Population densities (all census years) in most habitats were highest in the northern zone, lowest in the southern. In marshes, for example, densities in both 1907-1909 and 1957-1958 were about 130 grackles per 100 acres in the northern zone but only 11 per 100 acres in the southern.

liavorite summer habitats were edge shrubs and hedgerows, marshes, and residential areas, but grackles were found in all of the habitats censused. Densities of grackle populations in various summer habitats of the state in 1957-1958 were 268.5 birds per 100 acres in edge shrubs, 225.2 in hedgerow's, 158.0 in drainage ditches, 97.7 in marshes (56.8 in 19071909), 58.7 in residential areas (18.4 in
1907-1909), 33.7 in orchards (27.0 in 1907-1909), 25.6 in ungrazed grasslands (5.3 in 1907-1909), 19.3 in mowed hay, 17.9 in sweet clover, 16.5 in red clover (37.1 in 1907-1909), 15.2 in fallow fields (5.t in 1907-1909), 12.8 in pastureland (13.2 in 1907-1909), 12.3 in mixed hay (6.0 in 1907-1909), 10.6 in forest $(10.2$ in 1907-1909), 7.t in wheat (5.3 in 1907-1909), 6.6 in corn (7.7 in 19()71909), 6.2 in shrub-grown areas ( 1.8 in 1907-1909), 5.7 in oats (7.1 in 19071909), +.8 in soybeans, and 2.6 in alfalfat. In most habitats, the recent trend wals toward increased population densitics. The orchard populations are of interest, because the grackle is one of the very few species that had orchard populations ats dense in 1957-1958 as in 1907-1909.

Despite the high population densities of the grackle in certain habitats in recent vears, the state population of grackles declined slightly between 1909 and 1957, possibly because of habitat changes, particularly loss of marsh and orchard acreage. We estimated that June populations of grackles in the state were about,+ 100 ,000 in 1909 (probably about the same in 1907 ) , 3,600,000 in 1957, and 3,500,000 in 1958. The grackle population of Illinois changed in distribution between the two periods. In 1907-1909, grackles were concentrated especially in the northern zone $(t 1$ per cent of the state population) and the central zone ( 37 per cent) but, in recent census years, the central zone had only about 15 per cent of the state population. The cause of this regional change is not apparent. The increase in urban acreage should tend to swell the grackle population, particularly in northern Illinois, where the population density is highest.

Brown-Headed Cowbird.-In all census years, the brown-headed cowbird was found throughout the state in summer, but only in recent years and in the southern zone was it found in the winter season. Summer cowbird populations tended (all census years) to be most dense in the northern zone. In 1907-1909, the southern zone had the lowest population densities, but, in the recent census years, the central zone had the lowest densities.

'1he cowbird was encountered in virtually all of the summer habitats. Densities were highest in edge shrubs, hedgerows, 
and shrub-grown areas, which are probably the principal habitats of the cowbird hosts, but the cowbird appeared to have less marked habitat preferences than most species of lllinois birds. Densities of cowbird populations in various Illinois habitats in 1957-1958 were 55.5 birds per 100 acres in edge shrubs, 30.0 in hedgerows, 17.8 in shrub-grown areas (14.2 in 19071909), 7.8 in forest (6.t in 1907-1909), 7.5 in marsh, 5.4 in pastureland ( 8.3 in 1907-1909), 5.1 in ungrazed grassland, 2.9 in fallow fields (2.7 in 1907-1909), 2.7 in mixed hay (1.6 in 1907-1909), 2.5 in orchards, 2.1 in red clover (2.5 in 1907-1909), 1.8 in corn (1.7 in 1907$1909)$ and sweet clover, 1.3 in alfalfa, 0.9 in wheat ( 1.3 in 1907-1909), and 0.3 in oats (1.6 in 1907-1909).

Year-to-year variation in the cowbird population was particularly high, but we judge that the state population declined between 1909 and 1957. In nonwoody habitats in June, 1909 , the state population numbered about 1,800,000 cowbirds. The 1907 population in nonwoody habitats was probably about half as great (estimated from populations in the central and southern zones). In the recent census years, woody habitats accounted for most of the state cowbird populations, estimated to number about $1,130,000$ in 1957 and 920,000 in 1958. To some extent, the decline of pastureland acreage may have hurt the cowbird, particularly in the northern and central zones. Pastures were probably important to the cowbird, both as foraging and "nesting" habitats; northern zone densities in this habitat were about 23 cowbirds per 100 acres in 1907-1909 and only 5 in 1957-1958).

Despite the large summer populations in the early census years and the mildness of the 1906-07 winter, no wintering cowbirds were reported in the carly survey. About 350,000 cowbirds (most of them in shrub areas and small grain stubble) were found in the southern zone in January, 1957, but none in February, 1958. Like a number of other species, the cowbird maly be wintering farther north now than in earlier years.

Cardinal.- In the recent eensus vears, the cardinal was recorded throughout the state, both in summer and winter. Perhaps because of the small samples of woody habitats censused, it was not recorded in northern Illinois in 1906-1909. The cardinal has greatly extended its range northward since the turn of the century. In the later census years, the summer population thinned progressively north of the southern zone. For example, recent cardinal populations in Illinois forests in summer were about 23 birds per 100 acres in the southern zone but only 10 in the northern.

The cardinal was found during the summer surveys in marsh, fallow fields, ungrazed grassland, pastures, mixed hay and alfalfa fields, wheat, and corn, as well as in the favored woody habitats. Population densities in various habitats of the southern zone in 1957-1958 were 160.0 cardinals per 100 acres in colge shrubs, 22.8 in forest (23.t in 19071909), 20.6 in orchards (13.3 in 19071909 ), 15.8 in shrub-grown areas (36.1 in 1907-1909), and 9.2 in residential areas. Small samples of hedgerow acreage in 111 inois had populations averaging about 240 cardinals per 100 acres in 1957-1958.

The cardinal population in the state increased between 1909 and 1957 largely because of range extension, but also because of increased acreage of the favored woody habitats. In June, 1909, in all habitats (including woody habitats), there were about 650,000 cardinals in the southern zone; in June, 1907, there were about 400,000. In 1957 and 1958, southern zone populations were, respectively, about 780,000 and 980,000 . The southern zone then had about 70 per cent of the statewide cardinal population, which numbered about 1,200,000 birds in 1957 and 1,300,000 in 1958. Only about 8 per cent $(100,000$ birds $)$ of this total was in northern Illinois. IVe could not estimate the northern and central zone populations of cardinals for 1907-1909, because of the small simples of woody habitats censused. A forest sample in central lllinois in 1907-1909 indicated a population of about 19 cardinals per 100 acres, in contrast to 31 per 100 acres in 1957-1958. Cardinals were found in central zone pastureland in 1957-1958, but not in 1907-1909. It is clear that the northem and central zone populations of cardinals increased zreatly between 1909 and 1957.

The acreage of woody habitat in the 
cardinal's range increased between 1909 and 1957, but the summer population density in southern Illinois forests remained about the same. This situation suggests that the cardinal population in southern Illinois was about at the saturation point in 1907-1909 and remained so, keeping pace with the expanding habitat. ()ur data for central Illinois, though linited, suggest that the central zone habitats of cardinals were not saturated in 19071909, but that they were in 1957-1958; in the second census period, densities recorded for the central zone were even higher than those for the southern zone. The northern zone, apparently, had virtually no cardinal population in 19071909, and, even in 1957-1958, the habitats in the northern zone were far from saturated. In the coming decades, the cardinal population should continue to increase. Residential habitat is not so good for the cardinal as the natural types, but urbanization, as long as it encroaches on cultivated lands and not on forest, will benefit the cardinal.

Winter distribution of the cardinal followed the summer pattern (highest population in the southern zone, lowest in the northern); the surveys showed there was some tendency for the cardinal to visit open-field habitats more in winter than in summer.

'The cardinal is supposedly not migratory, but our data suggest that there may be a southward shift of the population in midwinter. In January, 1957, the entire state had an estimated population of about $2,000,000$ cardinals (1.6 times the June population), of which $1,700,000$ were in the southern zone. 'The number of cardinals in northern and central Illinois in January seemed to fall below the June level; the southern zone population in January was about 2.1 times its June level, in both 1907 and 1957. This hypothesized "migration" of the cardinal presents a problem that needs investigation through banding.

Indigo Bunting.-In all census years, the indigo bunting was found throughout the state in summer. The bunting population was most dense in the southern zone and decreased progressively northward. In Illinois forests, for example, population densities were about 17 buntings per 100 acres in the southern zone, 8 in the central zone, and $t$ in the northern.

In the course of the surveys, the indigo bunting was counted in virtually every habitat; woody types were the inost inportant habitats. Densities of bunting populations in various summer habitats of the southern zone in 1957-1958 were 295.0 birds per 100 acres in edge shruhs. $23+.5$ along drainage ditches, 228.3 in hedgerows, 39.9 in shrub-grown areats (42.2 in 1907-1909), 17.5 in forests (28.t in 1907-1909), 12.9 in orchards (11.0 in 1907-1909), 8.7 in wheat fields (1.7 in 1907-1909), $7 . t$ in fallow fields (0.9 in 1907-1909), 6.8 in ungrazed grasslands, and 4.1 in pastures. (0.3 in 1907-1909). The apparent increased importance of wheat fields as foraging habitat for this species in recent years is worthy of note.

The number of indigo buntings in Illinois probably increased at least slightly between 1909 and 1957. Population densities apparently did not change greatly in any zone, but the acreage of prime woody habitats for buntings increased in the southern zone and (slightly) in the central zone, the zones with the highest bunting populations. We estimated that June populations of indigo buntings in the southern zone numbered (in all habitats but edge shrub) about 850,000 birds in both 1907 and 1909 and (in all habitats) $1,+00,000$ in 1957 and $1,100,000$ in 1958 . We could not estimate summer populations in the northern and central zones for 1907 and 1909, because of the paucity of data on woody habitats, but our information on other habitats indicates that the bunting population of the state was higher in 1957-1958 than in 1907-1909. IVe estimated that the entire state had about $1,700,000$ indigo buntings in 1957 and $1,400,000$ in 1958. About 80 per cent of the state population of indigo buntings was in the southern zone, 15 per cent in the central, and 5 per cent in the northern.

Because densities of indigo bunting populations were about the same in all census summers, we do not expect great population expansion in this species, but some increase should occur if the acreage of woody habitats continues to increase. The bunting was probably not abundant 
in the primeval Illinois habitats of forest and prairie, and the original cutting of timber, because this cutting increased forest-edge and shrub habitat, probably favored the species.

Dickcissel.-One of the most abundant fringillids in Illinois, the dickcissel. was found (all census years) throughout the state in summer. Densities of dickcissel summer populations were consistently (all years and most habitats) highest in the central zone, lowest in the northern. Representative of this regional variation were recent densities of dickcissels in red clover fields: about 20 birds per 100 acres in the northern zone, 78 in the central, and $3+$ in the southern.

Favorite dickcissel habitats in summer were hayfields of all types, small grain and yrassland habitats, edge shrubs, and hedgrerows; dickcissels were found also in cornfields, soybean fields, plowed fields, orchards, and shrub-grown areas.

Population densities of the dickcissel in various summer habitats in central Illinois in 1957-1958 were 220.9 birds per 100 acres in edge shrubs, 163.5 in hedgerows, 115.8 in sweet clover, 93.t in mixed hay (33.t in 1907-1909), 77.9 in red clover (55.6 in 1907-1909), 80.6 in ungrazed grassland, 79.2 in fallow fields, $6+.5$ along drainage ditches, 28.8 in alfalfa, 22.3 in wheat fields ( 7.1 in 1907-1909), 17.8 in oats $(6.8$ in 1907-1909), and 8.2 in pastures (3.t in 1907-1909). Why populations of the dickcissel were consistently much lower in alfalfa than in other types of hay is unknown; alfalfa was also the least preferred hay type for the redwinged blackbird. The dickcissel and the redwing show some similarity in the placement of their nests.

Despite high variability in dickcissel numbers from year to year, it is clear that the population increased greatly between 1909 and 1957. In June, 1909, there were estimated to be $1,700,000$ dickcissels in the state; the 1907 population was lower (probahly about 1,500,000). In 1957 and 1958, the central zone had, by our estimate, about 2,250,000 dickcissels; the state population numbered about 3,350 ,000 birds in 1957 and 3,850,000 in 1958 . Populations in the northern zone (only 2 to 6 per cent of the state total) and in the southern zone ( 30 to to per cent) were much more variable than these in the central zone.

The dickcissel is another species that has adapted well to cultivated habitats that replaced the original prairie. In 1957-1958, dickcissel densities were highe' in fields of tame hay (as a group) than in the ungrazed prairie-like situations; total hay acreage increased between the two census periods. Even at the time of the early surveys, the dickcissel population was probably on the increase.

American Goldfinch.- In both summer and winter, the American groldfinch was recorded throughout the state. In all census years, populations tended to be most dense in the northern zone. In shrubyrown areas, for example, in the summers of 1957-1958, there were about t6 goldfinches per 100 acres in the northern zone of 1 llinois, $3.3 \mathrm{in}$ the central zone, and 5 in the southern.

'The goldfinch was found in nearly every summer habitat censused; shrubbery of all kinds, orchards, and ungrazed grasslands were particularly favored. Summer densities of goldfinch populations in various habitats in the northern zone in 1957 1958 were 167.5 hirds per 100 acres in edge shrubs, 96.2 in orchards, 69.9 in ungrazed grassland, t6.t in shrub-grown areas $(29.1$ in 1909), 7.3 in forest, $6 . t$ in pastures (2.1 in 1907-1909), 6.1 in oit fields (2.1 in 1909), and t.3 in marshland.

Because of the paucity of data on woody habitats in central and northern lllinois for 1907-1909, there is little basis on which to speculate about population changes in this species. Southern Illinois summer populations, at least, were roughly comparable in 1907 and 1958 (about 500,000 birds in each year). For the entire state, we estimated, the June populations of goldfinches numbered about 880 , 000 birds in 1957 and 1,000,000 in 1958. While population densities were consistently highest in the north, the southern zone had most of the good goldfinch habitat of the state, and therefore a high percentage (as much as +7 per cent in 1958) of the state population.

In winter, highest populations of the goldfinch occurred in forests, shrubs of all types, in pastureland, fallow fields, and ungrazed grassland, and (in 1906-07) cornstalk habitat. No species in Illinois 
showed more erratic Huctuations in population than the groldfinch; the winter distribution was particularly erratic. In the mild winter of 1906-07, there were, by our estimate, at least $1,600,000$ goldfinches (January, 1907, population) in Illinois, most (about 90 per cent) of them in the northern and central zones. In January, 195\%, the state population was the same as in June of that year, or about 900,000 birds, most (about 80 per cent) of them in the southern zone.

Savannah Sparrow.-In summer of both census periods, the savannah sparrow was encountered in the northern and central zones of lllinois. However, the population in the central zone in recent census years was sparse.

The savannah sparrow in summer was found in grassland habitats of all types, marsh, all hay crops, oat fields, and soyhean fields; populations were highest (all census years) in pastures and ungrazed grassland. Population densities of the savannah sparrow in various habitats in northern lllinois 1957-1958 were 38.5 birds per 100 acres in mowed hay, 27.8 in shrub-grown areas, 23.5 in ungrazed grassland, 20.8 in pastures (5.7 in 1909), 13.6 in red clover, 13.0 in mixed hay ( 1.7 in 1909), 4.3 in alfalfa, 3.9 in sweet clover, 2.8 in marsh (5.2 in 1909), and 2.1 in fallow fields (16.5 in 1909). Alfalfa and sweet clover proved to be relatively poor habitats for this ground-nesting species. The meadow-like marshes that were more numerous in the early survey years than later may have been a fairly important habitat for the savannah sparrow.

The savannah sparrow population in the state probably increased somewhat between 1909 and 1957 despite a loss in pasture acreage. In June, 1909, there were, we estimated, 160,000 savannah sparrows in the state (about 20,000 in the central zone). In both 1957 and 1958, the June population numbered about 390,000 birds, most in the northern zone. The savannah sparrow greatly increased its population in hay habitats; there was a general increase in population density that may have had no relationship to habitat acreage changes.

In winter, the savannah sparrow was recorded only in the recent census years and in southern Illinois, where the population was all but negligible.
Grasshopper Sparrow.-In all census years, the grasshopper sparrow was encountered in summer throughout the state; population densities were consistently highest in the central zone and lowest in the southern. In red clover fields, there were about + grasshopper sparrows per 100 acres in the northern zone, 9 in the central, and only 2 in the southern.

In summer, the grasshopper sparrow occurred in all grassland and hay habitats, oat and wheat fields, soybean fields, cornfields, orchards, and shrub areas. Densities of grasshopper sparrow populations in the most favored summer habitats in central Illinois in 1957-1958 were 53.2 birds per 100 acres in sand prairie, 42.5 in mixed hay (16.7 in 1907-1909), 40.9 in alfalfa, 9.3 in pastures (3.t in 1907-1909), and 8.9 in red clover (19.2 in 1907-1909). Populations of the grasshopper sparrow in fields of small grain changed hetween 1909 and 1957. In oat fields of the central zone, there were virtually no grasshopper sparrows in 1957-1958 (2.8 per 100 acres in 1907-1909); in wheat fields of this zone there were 1.6 grasshopper sparrows per 100 acres in 1957-1958 (1.1 in 1907-1909). Alfalfa, a relatively poor habitat for the savannah sparrow and a number of other grassland species, proved to be a high-density habitat for the grasshopper sparrow.

The grasshopper sparrow is a small species, and, except for the singing male, inconspicuous; in all likelihood, our density figures and population estimates are well below the true figures, but suitable for comparison within the study. Our data indicate that the grasshopper sparrow population did not change greatly between the two census periods. In June, 1909, we estimated, there were about 500,000 grasshopper sparrows in Illinois. The 1907 population was higher, probably exceeding 700,000 birds. June populations in 1957 and 1958 numbered, respectively, about 700,000 and 850,000 birds. In all years, the central zone had over 50 per cent of the state population; this latitudinal distribution was particularly marked in 1957-1958, when about 70-80 per cent of the lllinois grasshopper sparrows were in the central zone. The future for this species appears to be reasonably bright. Pasture acreage in Illinois continues to 
decline, but hayfields offer a good reservoir habitat.

Vesper Sparrow.-In all of the summer censuses, the vesper sparrow was found in the northern and central zones and, in 1957, also in the southern zone. About 90 per cent of the state population was in the northern zone.

The vesper sparrow was recorded in summer in all grassland and hay habitats, fallow fields, small grain, soybeans, corn, plowed fields, shrubbery of all types, and orchards; edge shrubs, red clover fields, and shrub-grown areas were particularly favored by this species. Population densities of vesper sparrow populations in various habitats of the northern zone in 1957 1958 were 58.6 birds per 100 acres in edge shrub, $1+.5$ in red clover (8.9 in 1909), 12.t in shrub-grown areas, 9.t in ungrazed grassland, 8.8 in mowed hayfields, 5.8 in alfalfa, 5.7 in pastures (2.6 in 1909), 3.t in corn ( 4.7 in 1909), and 2.9 in mixed hay (2.8 in 1909). The preference of the vesper sparrow for red clover was further indicated by the fact that, in the southern zone (the southern edge of the nesting range for this species), this sparrow was found only in red clover. The vesper sparrow, unlike most of the fringillids, occurred with fairly high frequencr in bare-field habitats, the row crops and plowed fields.

Neither the state population of the vesper sparrow nor its distribution changed greatly between 1909 and 1957. In June, 1909 , there were about 250,000 vesper sparrows in Illinois; the state population numbered about 390,000 in 1957 but only about 150,000 in 1958. The population of the southern zone probably did not exceed 10,000 birds in any year. Habitat changes between the two census periods should not have affected the vesper sparrow to any great extent; although the pasture acreage decreased, there was more red clover in 1957-1958 than in 19071909. Because the vesper sparrow nests in a greater variety of habitats than most of the open-field fringillids, and because it seems to favor even the bare-field habitats, it is surprising that this species did not show some gain in population. Other factors than habitat availability may have been responsible for holding the population at a low level.
Lark Sparrow.-In 1907-1909, the lark sparrow was found in all zones, but between 75 and 95 per cent of the state population was in the southern zone. By contrast, in 1957-1958, we recorded lark sparrows only in the central (about 90 per cent of the state population) and in the northern zone. To a large extent, the distribution of the lark sparrow is probably governed by the local distribution of sandy and other poor soils. In the recent surveys, we covered enough ground to be reasonably certain that the lark sparrow population in 1957-1958 in the southern zone was almost negligible by comparison with the 1907-1909 population in that zone.

Unlike virtually all of the other species censused, the lark sparrow showed no very decided habitat preference, perhaps partly because the soil requirement noted above overrides the vegetation requirement and partly because this sparrow nests in a broad variety of habitats, both on the ground and in trees. Population densities of the lark sparrow in various summer hahitats in the southern zone for 1907-1909 were 4.1 birds per 100 acres in pastures, 2.5 in fallow fields, 2.2 in cornfields, 2.0 in wheat, and 1.6 in oats. Densities in various habitats (sandy and poor soil areas only) in central Illinois in 1957-1958 were 25.2 lark sparrows per 100 acres in hedgerows, 14.3 in plowed fields, 5.5 in fallow fields, 2.0 in shrubgrown areas, and 1.2 in pastures.

In June, 1909, by our estimate, there were about 500,000 lark sparrows in Illinois, of which 370,000 were in the southern zone. The 1907 population was lower, but it exceeded 300,000 birds. Summer populations numbered about 80,000 birds in 1957 and 70,000 in 1958, most of which were in the central zone. The lark sparrow is a versatile species in its nesting habits, and it is difficult to understand why the population declined so much; the great loss in southern Illinois is particularly puzzling. Here we can only point out the need for a detailed study of the biology of the lark sparrow in Illinois.

Slate-Colored Junco.-In both survey periods, the slate-colored junco was recorded in winter throughout Illinois, but about 90 per cent of the state population (all census years) was in the south- 
ern zone; the numbers fell off sharply to the north. The junco was found in all of the winter habitats; edge shrubs, hedgerows, shrub-grown areas, and (in 190607 ) orchards had particularly high densities. Of the open-field habitats, fallow fields, ungrazed grasslands, cornfields of all types, and pastures were conspicuous favorites of the junco.

January populations of the junco in 111 inois numbered, by our estimates, about $5,300,000$ birds $(4,400,000$ in the southern zone) in 1907 (very mild weather) and $6,400,000(5,900,000$ in the southern zone) in 1957. 'The January population of 1957 was higher in most habitats than that of 1907 ; the 1957 population in the northern zone especially was high, about six times the 1907 level. These data fit a pattern observable in a number of other species-a trend toward higher winter populations at latitudes farther north in recent years. Published Christmas count records for central Illinois (Anon. 19001960 ) indicate that winter junco populations were neither unusually high nor low in 1906-07, 1956-57, and 1957-58. In February, 1958, the state population exceeded 10,000,000 juncos, and, because in the central zone the population was then almost four times the population in January, it was evident that northward migration was in progress, despite the severe weather conditions that prevailed. The high population of juncos in Illinois in February must have included a large number of migrants from wintering grounds south of Illinois.

Tree Sparrow.-In all census winters, the tree sparrow was found throughout Illinois. Unlike the junco, the tree sparrow was uniformly distributed in the state.

The tree sparrow occurred in virtually all of the winter habitats censused; like the junco, this sparrow especially favored edge shrubs and hedgerows, shrub areas, and, among open-field habitats, fallow fields and corn stubble. In 1906-07, the tree sparrow was much more abundant in corn stubble than in picked corn (cornstalk) fields; the latter habitat was preferred by most species of winter residents.

Examination of Illinois Christmas count data (Anon. 1900-1960) showed that the tree sparrow population was more highly variable than the junco population and that the number of tree sparrow's wintering in 1llinois was not unusual in 190607 or in 1957-58, but was abnormally high in 1956-57. The strip census data fit well with this picture. We estimated that January populations of the tree sparrow in Illinois numbered ahout $1,600,000$ in 1907 and 6,900,000 in 1957. The February population in 1958 was about 2,000,000 birds, and there was no indication of northward migration within the state, though many migrants could already have moved north of Illinois.

Chipping Sparrow.-In 1907-1909, the chipping sparrow was found throughout Illinois in summer; in the later survey period, this species was not recorded in central Illinois, and the population in the other zones was vestigial. Even during the early surveys, the chipping sparrow population was highly variable from zone to zone and from year to year; the southern zone had the highest population. In 1957-1958, most of the Illinois chipping sparrows were in the northern zone.

Favorite summer habitats of the chipping sparrow were residential areas, orchards, and pastures; in 1907-1909, the chipping sparrow was found in a variety of woody and open-field habitats. In the half century between survey periods, chipping sparrows were probably not very abundant in Illinois, but the June population numbered, by our estimates, about 250,000 birds in 1909 (probably almost as many in 1907) and less than 50,000 in 1957 and 1958. Habitat acreage changes may have had little to do with the decline. Loss of orchards would seem to have been detrimental to the chipping sparrow. Another favorite habitat, residential areas, increased in acreage with no apparent benefit to the species.

Field Sparrow.-In all census years, the field sparrow was found throughout the state in summer and in the southern zone in winter. Summer populations tended to be most dense in the southern and central zones, the zones that had the hulk of the optimum habitat; in all years, most of the state population was in the southern zone.

Favorite summer habitats for the field sparrow were shrubs of all types, hedgerows, orchards, and pastures. Densities of 
field sparrow populations in various habitats in the southern zone in 1957-1958 were 200.0 per 100 acres in edge shrubs, 91.3 in hedgerows, 53.t along drainage ditches, 37.4 in shrub-grown areas (46.9 in 1907-1909), 23.1 in orchards (59.7 in 1907-1909), 19.9 in pastures (8.6 in 1907-1909), 11.7 in fallow fields ( 8.8 in $1907-1909), 10.2$ in ungrazed grasslands, +.7 in forest $(28.4$ in $1907-1909)$, t.t in wheat ( 3.5 in 1907-1909), and 1.5 in hayfields of all types (3.0 in 1907-1909). Although many of the density figures indicated higher populations for the early than for the later census years, the density in pastureland, a declining habitat, was notably higher for 1957-1958 than for 19071909.

In June, 1909, the state population of field sparrows numbered, by our estimate, at least $2,100,000$ birds ( 75 per cent in the southern zone); the 1907 population was lower but probably exceeded 1,700,000 (these estimates do not include edge shrub or hedge populations). June populations in 1957 and 1958 were, respectively, about $1,+00,000$ and $1,000,000$ birds (62 per cent in the southern zone, both years).

Habitat acreage changes probably had some effect on the field sparrow population. In the summers of 1907 and 1909 , southern Illinois orchards alone accounted for over 100,000 birds, in contrast to 15 ,000 or less in 1957-1958. This change represents both an acreage loss and a loss in population density of the field sparrow in orchards. Though several insectivorous and frugivorous species showed density reductions in orchards between 1909 and 1957, the field sparrow is one of the few fringillids that declined in orchard habitat.

The increase in forest and shrub acreage between 1909 and 1957 would have helped the field sparrow population if population density had kept pace with the acreage increase in these favorable habitats.

Winter habitats for the field sparrow were the winter counterparts of the summer habitats in southern Illinois. The winter population of the field sparrow in Illinois has probably never been very large. We estimated January populations of this sparrow to be about $\$ 5,000$ birds in 1907 and 190,000 in 1957. The population in February, 1958, was almost negligible (about 10,000 birds), and there was no indication of northward migration. Field sparrows, like birds of a number of other species, probably drifted farther southward in late winter.

Song Sparrow. - In the recent surveys, the song sparrow was found throughout Illinois in both summer and winter. In 1907-1909, the species was widely distributed in winter, but it did not occur in the southern zone in summer. In all census summers, the song sparrow population was most dense in the northern zone. In shrub areas, the northern zone had about 37 song sparrows per 100 acres, while the central zone had only 8 per 100 acres; the southern zone had only a negligible population. Densities of song sparrow populations in various habitats in the northern zone in the summers of 1957 1958 were 95.9 birds per 100 acres in edge shrubs, 62.9 in hedgerows, 37.1 in shrubgrown areas, 32.0 along drainage ditches, $11 . t$ in marshes (5.2 in 1909), 11.0 in orchards, 5.2 in ungrazed grasslands (20.3 in 1909), 3.9 in sweet clover, 3.2 in pastures, 2.7 in red clover, 1.7 in forest, and 1.4 in mixed hay (2.8 in 1909). Along with its range extension southward, the song sparrow population in Illinois probably increased at least slightly between 1909 and 1957. By our estimate, June populations of the song sparrow in Illinois numbered about 180,000 birds in 1909 , 250,000 in 1957, and 290,000 in 1958 . At least 2,000,000 acres of Illinois land were not accounted for in these estimates, and this acreage-probably various marginal habitats-may include a significant amount of prime song sparrow habitat. Thus, the actual state population may be much higher than our estimates for this species. Habitat acreage changes between the two census periods had only slight effect on the song sparrow population. Loss of marshland, orchards, and pasture was largely balanced by increase in forest edge.

In winter, though song sparrows occurred throughout Illinois (all census years), most of the state population was in the southern zone, where the winter population exceeded the summer population. Ungrazed grasslands, shrub habitats, marshes, and drainage ditches were espe- 
cially preferred winter habitats of the song sparrow. By our estimates, January populations of song sparrows in Illinois numbered about 350,000 birds in 1907 ( 88 per cent in the southern zone) and 475 ,000 in 1957 ( 70 per cent in the southern zone). Like many other species, the song sparrow may be wintering farther north in greater numbers now than in earlier years.

This sparrow may be more tolerant of cold than many other migratory fringillids. As many as 70.000 song sparrows wintered in the northern zone, and, unlike the birds of many of the species considered in this report, song sparrows did not appear to move southward in late winter shortly before the onset of spring migration. Our data indicate that, despite severe winter weather, song sparrows were migrating north in great numbers in February, 1958, when the southern population was swelled to about 900,000 birds, presumably by an influx of migrants from farther south.

Lapland Longspur.-In the first winter survey (1906-07), the Lapland longspur was found only in the northern zone of Illinois, but, in 1956-57, this species was abundant in both the northern and central zones; in 1957-58, it was recorded throughout the state. In recent census years, January population densities were highest in the central zone.

Like the horned lark, the Lapland longspur in winter particularly favored open habitats with relatively little cover; apparently some low cover was important in the habitat. In the central zone, population densities in recent census years were about $8+$ hirds per 100 acres in cornfields, 51 in alfalfa, +2 in soybean stubble, and 28 in small grain stubble, but only 5 in plowed fields.

In January, 1907, by our estimate, there were about 700,000 longspurs in Illinois, all in the northern zone. In January, 1957, the state population numbered about $+, 800,000$ birds, most of them ( 86 per cent) in the central zone and none in the southern. Longspur populations are known to be extremely variable, and perhaps the great difference between the 1907 and 1957 populations falls within the range of "normal" year-to-year variation. Both winters were mild, at least until late
January. In recent years (1956-1962), we have found the longspur to be common in central Illinois every winter, and it is possible that the species is extending its winter range southward, or perhaps eastward. Habitat changes probably favored such an extension. Cornfields, which now make up a large part of the Lapland longspur habitat in winter, were of little value to the longspur in earlier times when handharvesting methods left stalks standing; the cover was too dense and tall for this species. The initiation of mechanical harvesting methods, which flatten stalks to the ground, and the beginning of soybean agriculture created millions of acres of prime winter habitat for the longspur in Illinois.

In February, 1958, longspur distribution in the state had a pattern not seen previously. In this time of extremely adverse weather conditions, longspurs (probably about 5,700,000) occurred throughout the state, but in greatest numbers in the southern zone (about 3,200,000). Coincident with a great increase in the population of the southern zone, the number of longspurs in central Illinois fell from the January level of $4,150,000$ to about $1,900,000$. Obviously, the population had shifted southward in late winter, but whether this is an annual occurrence remains to be determined.

\section{DISCUSSION}

Much of the world's ornithological literature deals expressly with variations in populations of wild birds, but still we know relatively little about rates of change in these populations. We know that, in time, even the species is transient; examining the fossil record (Wetmore 1940), we find no positive evidence that any North American bird species now extant has survived more than about 10 ,000,000 years. In less time-since the beginning of the Pleistocene, perhaps a million years ago-the number of species in the North American avifauna has probably been reduced by about one-fourth. In much less time, many important faunal changes have become matters of historical record. In the Illinois avifauna alone (Smith \& Parmalee 1955), we could note the disappearance, within the past 100 years, of at least a dozen species and the 
establishment in numbers of half a dozen more. Looking back, we perceive faunal changes and acknowledge that they are continuing. The fauna that we study now is an ever-changing heritage from the past. Though in a broad sense evolution has no beginning and no end, it has directions that are affected by factors untold in number.

The annual fluctuations that characterize all bird populations make it particularly difficult to identify changes that have direction and relative permanence. Certain faunal changes (for example, range extension by such conspicuous species as the cardinal and the mockingbird) are easily detected even in their early stages. Other faunal changes (for example, the decline leading to extinction of a species) may be noticed only in the later stages of the change. Some trends may be detected only in the light of periodic population measurements.

The need for detailed censuses of birds was recognized long ago, but, despite the initiation of the Christmas counts in 1900 (Chapman 1900:192), two nationwide summer censuses sponsored by the United States Biological Survey (Cooke 1915, 1916), and subsequent development of a regular program for censusing breeding birds (Hickey 1937), there are still relatively few bird population data available for much of North America. Most recorded population measurements of high quality are provincial in avifaunal, ecological, and geographical scope and span only relatively short periods of time. Information for habitats other than forest is particularly scarce, though the census program is expanding steadily through the voluntary efforts of many ornithologists.

The value of srstematic bird censuses increases as the years pass, for without some reference to the past we cannot see the trends of evolution; we can see neither the magnitude nor the direction of change. In terms of quantitative data on bird populations in North America, we have few reference points before 1915. In view of the paucity of quantitative data, and the habitat changes that have occurred in the past half century, the efforts of Stephen A. Forbes and Alfred O. Gross to provide detailed information on the bird life of 1906-1909 in virtually every habitat in
Illinois appear particularly farseeing and commendable.

Almost inevitably, the field biologist, because he deals with many variables, becomes uneasy about the adequacy of his data. In this paper, our interpretations are based on a record of only + years, 2 early in this century and 2 in midcentury. For many species of birds, the temporary fluctuation in population between two consecutive census years might far exceed any irreversible directional change that would occur in a period of 50 years or more. Fully recognizing the possibility of confusing short-term fluctuations with relatively permanent changes, we have still accepted the differences between the 19061909 and 1956-1958 data largely at face value. In our conclusions, we have been guided for the most part by the strip census records. The data presented in tables and text are always open to reevaluation, and the reader should bear this fact in mind.

\section{Events Previous to 1800}

Following the last glaciation-perhaps 10,000 years ago (Livesay 1951:23)and before white settlement, there were probably few types of bird habitats in the area that was to become the state of Illinois. In succession, the melting glaciers gave way to open lakes, to marshes, and then largely to drier habitats of grassland and forest. The present Illinois soil types indicate that in pre-Columbian times and as late as about 1800 approximately 14,000,000 acres were forested (King \& IVinters 1952:20) and between 21,000, 000 and 22,000,000 acres were primarily prairie grassland. Included in these total acreages there were probably more than the $1,+00,000$ acres of wetlands reported by Shaw \& Fredine (1956:5) for a later period. Naturally disturbed forest areas (areas disturbed by fire, flood, or erosion) undoubtedly gave rise to some shrub habitat, but the acreage of this habitat is inestimable.

Quantitatively, at least, the Illinois avifauna of 1800 and before is unknown. If we could assume bird population densities for 1800 similar to those of the early 1900 's for the acreages in the primary habitats of forest, marsh, and prairie, then in 1800 and probably many years before 
the Illinois areal would have had a breeding bird population of about $97,000,000$ birds-53,000,000 in forest, 7,500,000 in marsh, and $37,000,000$ on the prairie.

In the vears previous to 1800 , man was a minor force in effecting faunal changes in the Illinois country. 'The Indian inhabitants of this area cultivated some land, probably only a few thousand acres. Marquette reported that the Illini tribes numbered 8,000 or 9,000 persons in 1670 (Temple 1958:14). 'The Indian population of the area dwindled through the 19 th century. Zebulon M. Pike reported that in 1805 the Sauks and Foxes, who had largely replaced the Illinois tribes, together numbered only about,+ 600 persons ('Temple 1958:99-101). These thin populations had probably transformed but little of the natural habitats of the area.

\section{Development of Managed Habitats}

White settlement of the Illinois country, which began about 1700 (King \& Winters 1952:10), was still negligible by 1800. In 1798, there were about 5,500 whites in the area that later formed the states of Illinois, Indiana, Wisconsin, and Michigan (Hagan 1958:3). In the following century, the $19 \mathrm{th}$, most of the Illinois lands came under cultivation. In that century, perhaps as many as $10,000,000$ acres of forest were removed. If our hypothetical estimate of the bird population of 1800 was correct, the decimation of Illinois forests in approximately 100 years was tantamount to the elimination of about $38,000,000$ breeding birds from the state. Hicks (1935:306) suggested that the orginal forest in eastern North America, because it offered relatively little edge, may have been poor bird habitat. Even if it was poor habitat and our estimate for 1800 was considerably high, 19 th century deforestation must have taken a tremendous toll of Illinois birds. Areas adjacent to the Illinois country were also coming under the plow, and forests that remained must have been quickly populated to saturation.

In the 19th century, also, grassland and marsh habitats were being transformed. By 1830, Illinois had nearly 160,000 whites (Anon. 1832:38). By 1850, it had $12,000,000$ acres in farmland (Anon. $1936: 151)$; the farm acreage almost dou- bled in the next decade and reached about $33,000,000$ by 1900 . The acreage of corn, oats, and cultivated hay more than doubled between 1866 and 1900 (Anon. $1936: 153,155,165)$, supplanting most of what remained of the original $36,000,000$ acres of natural habitats. What was left by 1900 was about $3,500,000$ to $4,000,000$ acres of forest (some of it grazed), about a million acres of prairie grasslands and marsh combined, and a vast expanse of land in various stages of cultivation. Most of the cultivated habitats, new to Illinois, were without an avifauna. Some prairie species held on in marginal prairie acreage, and for a number of prairie birds there was probably little hardship in the transition from wild prairie to tame or cultivated hay, or to pastureland that was not overgrazed. In 1900, the row crops, plowed fields, and small grain fields, which occupied nearly 20,000,000 acres, were for breeding birds largely a void to be partially filled later by the horned lark.

Particularly in southern Illinois, deforested areas that did not come immediately under cultivation were quickly occupied by a shrub flora and avifauna. The century that saw the Illinois forests decimated brought approximately 300,000 acres of orchards into being, and, between the marginal forest species and the marginal prairie species of birds, the orchards had a ready-made avifauna. In that century, too, a notable acreage (probably about 350,000 acres by 1900) of human residential habitat developed in Illinois. Much of it rural and adjacent to orchards, residential habitat usually had tree and shrub cover of its own that claimed some segments of the forest and shrub avifaunas.

By 1900, over much of Illinois and the Midwest, there was beginning to be an agriculture-adapted avifauna. The trends of change were established, and the ensuing 60 years saw them continued. As in previous times, some species adapted to the change. In a few cases, man unwittingly adapted the environment to suit the species.

The past 150 years in 1 llinois have seen the beginning and development of a specialized kind of evolution. Albeit unwitting, it is, nonetheless, evolution by management. The pattern of change is not 
basically different from that in previous times, when other species of animals probably "guided" evolution to some extent, though the rate of change may never before have been so fast.

In little more than 100 years, the Illinois landscape changed immensely, from a few relatively high density habitats with an estimated June population (primarily nesting adults) possibly as high as 97,000 ,000 birds in 1800 to the diversified, managed habitats of 1907, which supported about $61,000,000$ birds. In the next half century, the state avian population changed but little in total number. There is more to the picture of changing bird populations in Illinois than these gross population figures can tell. None of the population changes, of course, represented a general decrease or a general increase in the whole population. Of the 40 most abundant species of birds in the state, 17 showed notable population increases in the half century, 17 showed decreases, and 6 had about the same populations in 1907 1909 as in 1957-1958. There was selection, adaptation, extirpation; in short, there was evolution continuing. If we emphasize the changes of the half century between the two surveys, it is only because of the temporal limits of our data, for the patterns of change that led into the 19th century are continuing still.

\section{Specific Changes in Avifauna}

The basic patterns of change in the Illinois avifauna during the five decades between the two surveys can best be presented by example. For many of the changes observed we can offer no explanation, and, in all cases, the reader should bear in mind that it is easy to oversimplify so complex a phenomenon as evolution. Unless otherwise stated, the population figures presented represent June populations, primarily the adult nesting poputions.

Earlier, we noted that there was no ready-made avifauna for most of the newly developing, managed habitats of 19 th century Illinois. An increasingly greater use of some of these habitats by certain species of birds, both exotic and native, was a dominant trend of many decades.

A case in point was the utilization of residential habitat by exotic species. Intro- duced species thrive in managed habitats, and arrival of the house sparrow on the continent could not have been timed much better to take advantage of the swelling acreage of residential habitat. In 19071909, the house sparrow was already a part of the Illinois avifauna, and was, in fact, probably the most abundant species in the state, with a population of at least $5,300,000$ birds. The sparrow population was only slightly higher in 1957-1958 than in 1907-1909; in the intervening years, the house sparrow, like man, had become increasingly urban in distribution. The starling, which was not even present in the state until about 1926, well after the early surveys, attained by 1957-1958 a state breeding population of at least 3,100,000 birds, most of them in residential areas.

What effect the starlings had on other cavity-nesting species can only be surmised. At least partly coincidental with increasingly greater numbers of starlings. flicker populations in the state fell from about 2,300,000 in 1909 to 300,000 in 1957, and the numbers of red-headed woodpeckers declined from $1,300,000$ in 1909 to 130,000 in 1958 . These native birds are not strictly forest species, but inhabitants of marginal, savanna-type, or even residential habitats, and they almost certainly came into competition with the starling. In recent years, flicker populations in residential habitat were inversely proportional to the starling population, and starling numbers are presumably still increasing. Such native cavity nesters as the red-bellied and hairy woodpeckers. which are more restricted to the natural forest habitat, have not had to compete much with the starling and have shown no population decline. The evidence against the starling, though circumstantial, appears incriminating. During the habitat changes of the 19th and early 20th centuries, some native species found a niche in man's residential habitat, but, to the medium-sized cavity nesters in this group, the introduction of the starling was destructive.

These exotic species were adapted to the residential habitat even before their introduction into Illinois. Two native species, the chimney swift and purple martin, were probably adapted to the urban situation 
long before 1900. From a broad ecological background in 1907-1909, the robin population in Illinois had, by 1957-1958, come to survive almost entirely in residential habitat. Like the human population, the robin population has been concentrated particularly in northern lllinois.

Adaptive utilization of cultivated habitats extended to some open-country birds. Two examples deserve special discussion here.

At least since the time of the early surveys (and presumably in previous ages), redwinged blackbird populations have attained their maximum densities in cattail marshes. In 1907-1909, though redwings occurred in prairie, hayfields, and other habitats, most of the state population, which numbered about 5,000,000 birds, was in marshland. By 1957, the population numbered over $8,000,000$ ( $11,-$ 000,000 in 1958), and most of the Illinois population was in cultivated habitats, particularly mixed hay. In the period 19071957, marshland, which had been largely restricted to the northern half of the state, dwindled to a tenth of its 1907 acreage, and sod grasslands gave way increasingly to cultivated hay throughout the state. In this more widely distributed habitat, the redwing population swelled. The redwing may be expanding its utilization of secondary habitats even further. For instance, there is clear indication of increased use by the redwing of small grain fields, a habitat reservoir amounting to several million acres. This trend promises further increase in the redwinged blackbird population.

Even more spectacular than the population increase of the redwinged blackbird was the change in population of the horned lark. Between these two species, there was a subtle, but basic, difference in the mechanism of change. For the redwing, marshes were, and still are, the favorite habitat (judged from population densities) ; yet the redwing invaded a secondary habitat that by 1957 supported most of the population. For the horned lark, man unwittingly created what proved to be an "optimum" hahitat. Before white settlement, the horned lark probably resided in the relatively barren parts of the prairie grassland, and its population was probably not very great. The lark avoids tall cover, and bare ground is apparently an important part of its habitat. The great 19th century expansion of agriculture opened a vast land to the lark. With white settlement, increased grazing on the primary grasslands improved, for the lark, the original habitat, but even from pastures the lark moved increasingly to tilled land. The newly opened habitats were not saturated in 1907-1909 when the Illinois horned lark population was under $1,500,000$ birds; by 1957-1958 there were about 5,000,000 horned larks in the state. For the horned lark, this population change in Illinois was probably representative of changes in other parts of the Midwest (Hicks 1935:308).

\section{Specialization in Managed Habitats}

The adaptation of bird species to the cultivated scene was but one major force in shaping the present avifauna. The cultivated habitats themselves became more specialized through changes in management.

Here, for one example, we can refer to changes in orchard management to show at least two ways in which bird populations were affected. While the density of the total bird population in orchards was about the same in 1957-1958 as in 19071909 , certain species, principally insectivorous and frugivorous types such as the eastern kingbird, robin, blue jay, the mimids, and orchard oriole, tended to disappear from the orchard avifauna. At least some of these species maintained or even increased their population densities in other habitats. Why they should have declined in orchard habitat particularly is a problem that needs further study. The increased use of insecticides in orchards and the development of organic insecticides may have had some bearing on the change. Much of the orchard acreage in 19th and early 20th century Illinois was composed of noncommercial farmyard orchards that probably received little insecticide spraying. Later these farmyard orchards gave way largely to commercial stands that received regular treatment with insecticides.

Both the change in size of individual orchards, from family farm plots to large commerical stands, and the great decline in total acreage of orchards had their effect on the avifauna. The commercial tracts of 1957-1958 had a decidedly uni- 


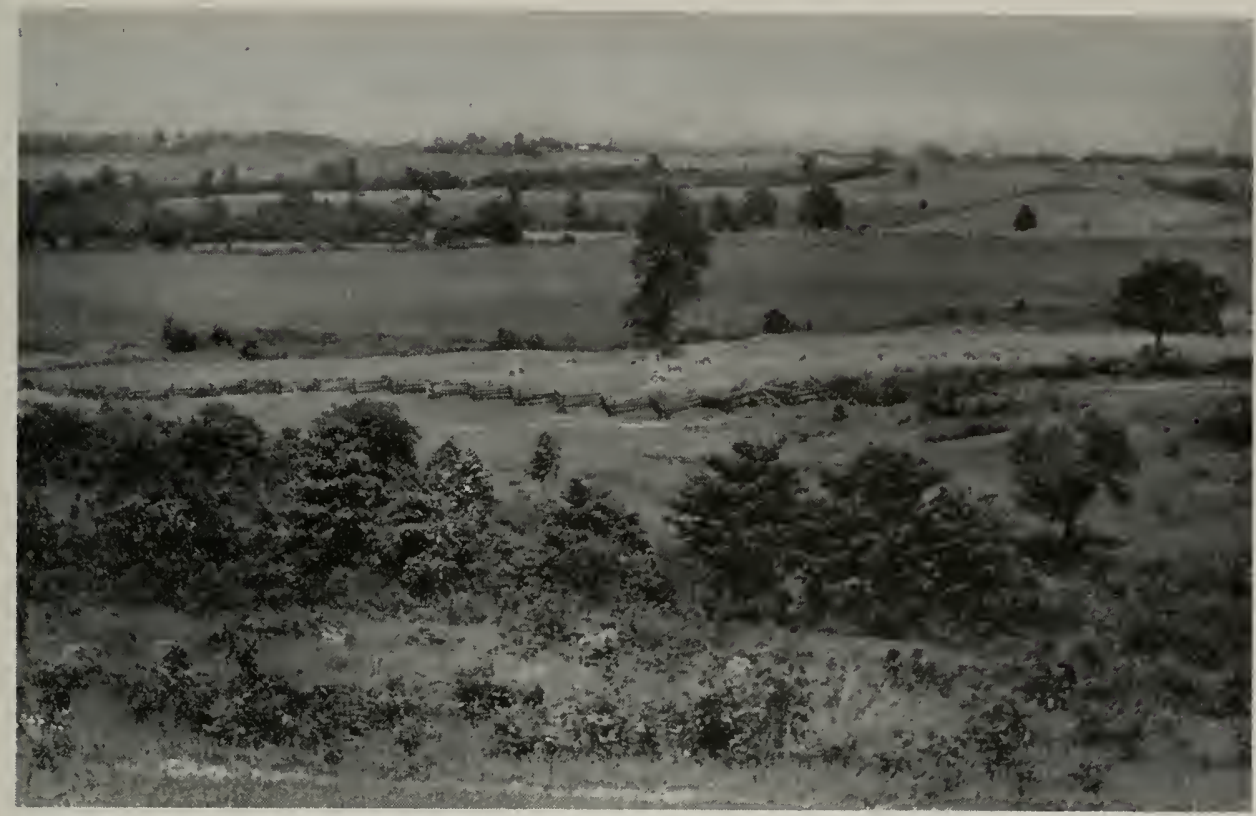

Fig. 29.--Southern Illinois landscape in June, 1907. The distribution of open fields and scattered clumps of shrubs and trees suggests a kind of savanna area. This type of cover distribution greatly favored a large variety of bird species. The loss of this habitat arrangement in recent times has contributed to a loss of avifaunal variety in Illinois. The photograph was taken + miles west of Shetlerville, Hardin County, June 28, 1907, by Alfred O. Gross.

form aspect and offered much less edge than did the small farm plots of previous decades.

To many species of birds, edge or marginal habitats are extremely important; after 1900, we entered an era of increasing field size and agricultural specialization in which edge habitats were diminished. The practice of removing hedgerows and other field-edge vegetation, as well as isolated trees within cultivated fields, became increasingly prevalent. Part of the modern practice of clean cultivation is the reduction of weeds in pastures and crops of all kinds through mowing or the use of chemicals; this practice may affect bird populations by erasing some nesting and foraging niches (Scott 1958:389). Now even fences are being eliminated from field edges in many parts of the state. Elimination of these fences in effect results in the elimination of a multitude of singing perches for birds. I ts influence, if any, on bird life in the state is a subject that needs research.

In the late 19th and early 20th centuries, much of the land of Illinois had the aspect of a kind of savanna, figs. 29 and 30 . This savanna-type habitat, a transitional stage between the natural postglacial habitats and the specialized block terrain of agricultural management, has been largely eliminated. Just as 19 th century deforestation removed a segment of the fauna from large areas of the state, so 20 th century elimination of savannatype habitat removed another group of birds from extensive areas.

An important change in the lllinois avifauna during several recent decades was the waning, on a massive scale, of certain bird populations, particularly in the southern zone of Illinois. Many species were involved in this change, including at least the following: upland plover, yellowbilled cuckoo, mourning dove, flicker, redheaded woodpecker, eastern kingbird, blue jay, mockingbird, brown thrasher, robin, orchard oriole, lark sparrow, chipping sparrow, and field sparrow. For all of these species (combined) the net population loss in southern Illinois between 1909 and 1957 amounted to $4,000,000$ breeding birds (minimum estimate). 
Most of the species involved in this decline have at least one major ecological characteristic in common: except for the upland plover they are species of marginal, edgre, or savanna-type habitats. Most of them are, therefore, species that probably increased greatly in population after 1800 as the land was transformed from its primeval state and broken into small farm tracts. These species probably reached a peak around the turn of the century. 'Their decline began after 1900 , as the number of farms and the acreage of sod grassland decreased, as cultivated fields increased in size, and as clean farming methods removed edge shrubs, solitary shade trees, and family orchards. Most of these habitat changes are still continuing.

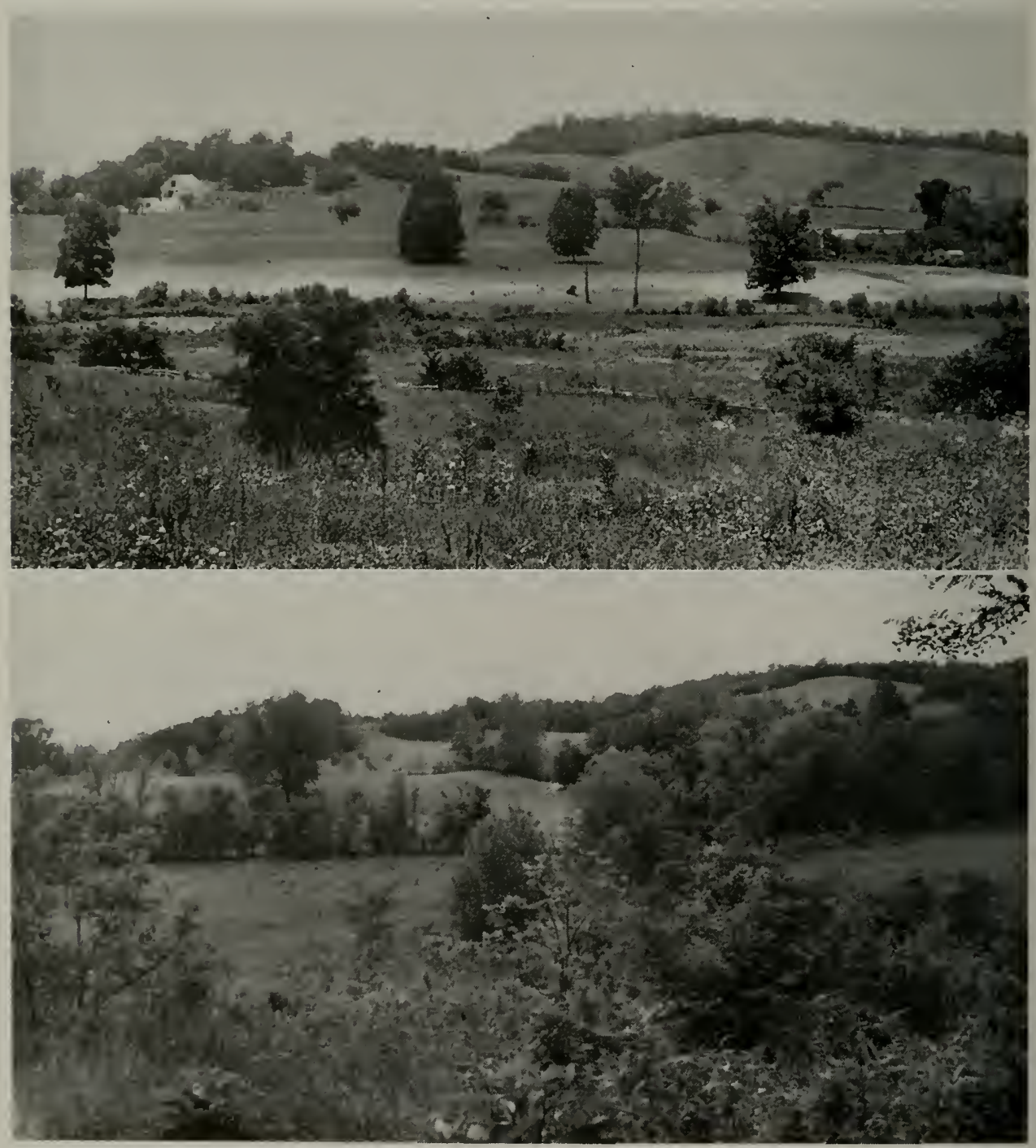

Fig. 30.-Landscape near the Ohio River, Hardin County, southern Illinois, 1907 and 1963. Upper picture taken 3 miles west of Cave-in-Rock, July 1, 1907, by Alfred O. Gross. Lower picture, same area as upper picture; taken May 19, 1963, by Richard R. Graber. Timber is filling in the old savanna-type habitat. The barn in the distance at the left in lower picture was built on the site of the barn shown in the 1907 picture. This farm has been owned by the same family for many years. 


\section{Population Density and Avifaunal Variety}

The increased specialization in managed habitats, with consequent diminishing of the savanna-type habitat, was only one ecological change that effected a loss of avifaunal variety in Illinois. Another ecological change having a similar effect was the adaptation of particular species to managed habitats.

If we examine the bird habitats and their associated faunas, we can see a direct relationship between the complexity of a habitat and the complexity of its avifauna. Row crops, which offered few niches and few types of niches for birds, were the poorest of the habitats both in numbers of birds and numbers of species. Woody habitats, which offered many niches and many types of niches for birds, supported high populations and varied avifaunas.

Beyond this primary direct relationship between density and variety, which can be seen in the whole gamut of habitats and avifaunas, another relationship between population density and faunal variety characterizes managed habitats only. By reducing floral variety in a habitat, man increases habitat specialization, therefore faunal specialization, and, in the transition from natural to managed habitats, avifaunal variety tends to decline while population density tends to increase.

The basic difference between natural and managed habitats can best be illustrated with specific examples by considering the faunal characteristics of a natural habitat and its managed counterpart. Thus, uncultivated grasslands supported a greater variety of common bird species than did the hay crops, but the hay crops supported denser populations. Residential habitat, a modified type of forest, supported much denser populations of birds, but a much smaller variety of species than natural forest. 'The greater the degree of specialization in the habitat and its constituent avifauna, the higher the population density can be.

Cause and effect in the relationship between population density and avifaunal variety are difficult to establish, but ultimately they relate to the variety and number of niches that a habitat offers and to the interspecific competition for these niches. Characteristically, managed habitats offer a large number of niches, even though a small number of niche types, and the bird species best adapted to these niches occupy them so completely as to

Table 56.-Estimates of breeding populations of common species of birds in Illinois, 1909 and 1957. The estimates are for all acres of the habitats accounted for in this study. The species listed comprised about 70 per cent of the birds in these habitats in the years indicated.

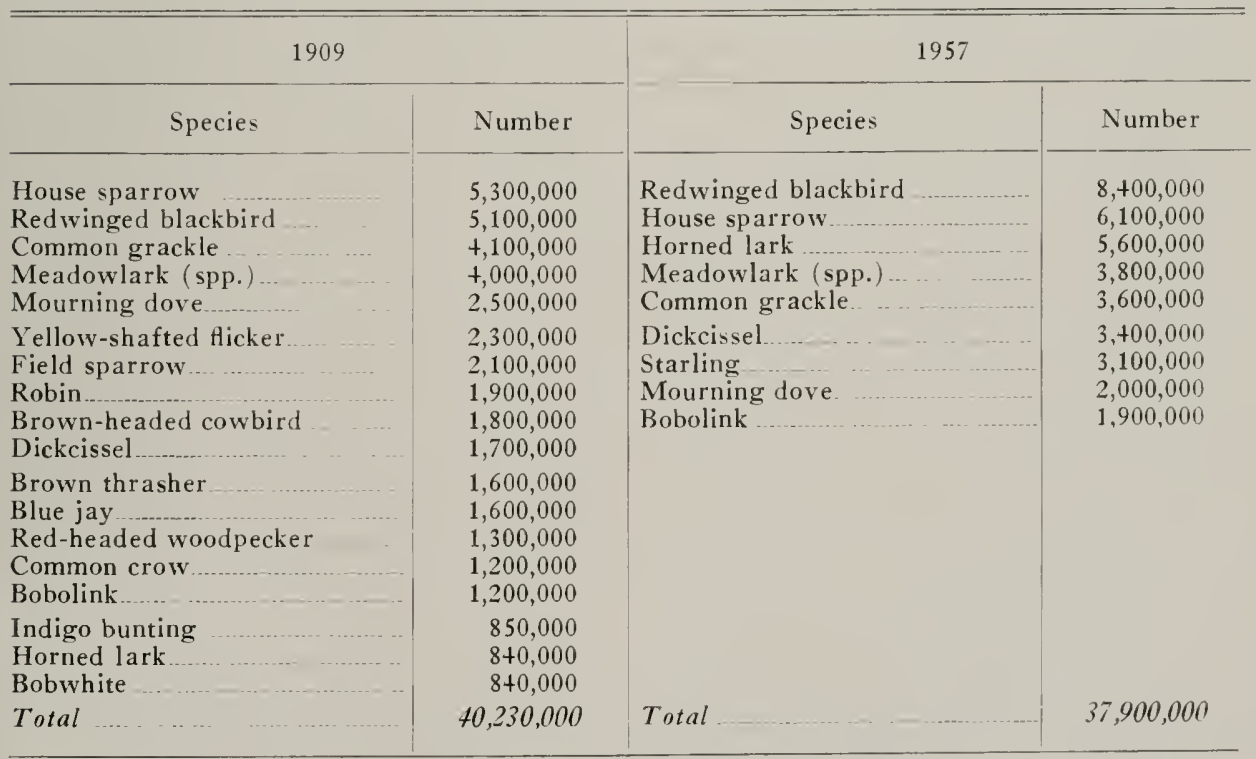


exclude other species of birds. The end result of such occupation is an avifauna with high population density but little variety. Pertinent here is the fact that in each of the managed high density habitats used as examples above (hay crops and residential areas) part of the bird population was composed of species (purple martin, house sparrow, starling, and redwinged blackbird) that show a high degree of intraspecific tolerance. It is such species, particularly, that increased in population after 1909 . We must bear in mind that managed habitats, which have poor avifaunal variety, are the expanding habitats. Since the turn of the century, the acreage of cultivated hay has grown as the acreage of prairie grasslands has dwindled.

The trend toward specialization of habitats and their associated avifaunas (elimination of savanna-type habitat was a parallel trend) tended to reduce the number of bird species that could be classed as common in the state. A reduction in common species has become apparent even since 1909. If we arbitrarily define the common species as those comprising 70 per cent of the state population, we find that there were, in the Illinois avifauna, 18 common species (about $40,000,000$ birds) in 1907-1909 and only 14 common species $(+2,500,000$ birds $)$ in 1957-1958. Data for 1909 and 1957, the years of best coverage, show an even greater difference in arifaunal variety, table 56.

\section{Population Changes and Latitude}

Although specialization of habitats and adaptation by particular species to these habitats were dominant forces of change in shaping the present Illinois avifauna, certain special changes were important enough to deserve elaboration. IVe noted earlier that a number of species of birds suffered population losses, particularly in the southern zone of the state. No single factor could account for the waning populations in all of these species. The populations of most of these species had been highest in 1907-1909 in the southern zone, and therefore that was the zone in which they had the most population to lose. Most of these species lost population in other zones, also, but a few-for example, the catbird and robin-actually increased their northern populations, while losing in the south. Others lost proportionately less in the northern zone than in the southern. The brown thrasher population, for example, fell from about 160,000 birds $(1907-1909)$ to 130,000 (1957-1958) in the northern zone (about 20 per cent loss), but from 800,000 to 180,000 in the southern zone (about 80 per cent loss). The effect of these specific changes can be seen and expressed in terms of the entire state population of birds, for, between 1909 and 1957, the breeding-bird populations of northern and central Illinois actually increased, while the breeding-bird population in the southern zone declined, or, at best, merely held its own. Why, within a species, did the population in the northern zone survive better than that in the southern? This question suggests another group of problems in Illinois ornithology that need further investigation. It is a mistake to assume that all of the species showing decline are responding to the same factors, thougl, to some extent they may be.

The fact that the population losses varied with latitude suggests the possibility of climatic influences on the populations. The continent has probably been in a generally warming trend since the last glaciation; the temperature climb has been studied in detail since 1885 (Conover 1953). How, or if, this climatic warming has affected survival of breeding birds remains to be determined. Pertinent here are the notable changes in winter distribution of lllinois birds. Several species, including the mourning dove, mockingbird, robin, the meadowlarks, redwinged blackbird, swamp sparrow, and song sparrow, either extended their winter range northward in the state between 1909 and 1957 or wintered in Illinois in larger numbers in 1957-58 than in 190607. The winter (January) population of birds in lllinois increased from about 30 ,000,000 in 1907 to $55,000,000$ in 1957 . The factor or factors that effected population changes in the state winter population may also have influenced the breeding population.

\section{Range Extensions}

Among the types of change in the Illinois avifauna between 1909 and 1957, range extensions by a few species deserve 
special mention. Of the common species censused, at least seven, all but one primarily southern forest species (turkey vulture, red-bellied woodpecker, Acadian flycatcher, tufted titmouse, Bell's vireo, cardinal, mockingbird, and probably the Carolina chickadee), extended their breeding range northward, and four, all icterids (bobolink, western meadowlark, yellowheaded blackbird, and Brewer's blackbird), extended their range southward or southeastward. The larger number of species moving north than south probably reflected the fact that deciduous habitat species were more numerous in the south. In addition to the species that made range extensions, there were a few species that greatly increased their breeding populations in one zone particularly. Probably the most notable example was the barn swallow, which enlarged its southern zone population tremendously from a very low level in 1907-1909.

In most cases, range extensions occurred from saturation or near-saturation populations in adjacent areas. The red-bellied woodpecker, for instance, was essentially a southern species in 1907-1909, with a saturation population in its primary habitat (forest) of about 5 birds per 100 acres. By 1957, this species had attained populations of the same density in the central zone and was still spreading northward, though populations in the northern zone were sparse ( 1 bird or less per 100 acres). At least two species, the turkey vulture and mockingbird, spread their populations northward despite thinning in the southern zone.

The range extensions of the several species of icterids mentioned above fit a broad pattern of change. All of these species experienced notable population increases between 1909 and 1957; all are marsh-inhabiting or open-field representatives of the blackbird family. Such a consistent trend toward population increase among the species of one family suggests the possibility of some particular genetic vigor, or at least a genetic unity that makes them all favorably responsive to the changes that man has wrought. The grackle, which qualifies both genetically and ecologically for this group, merely held its own between the two survey periods, but it found a niche in the expand- ing urban habitat and should, in time, increase; the two strictly arboreal nembers of the family, the orchard oriole and the Baltimore oriole, suffered population decline.

\section{Habitats and the Future of the Avifauna}

In a very general way, we have traced the development of our present Illinois avifauna. To know more precisely where the avifauna is in its sequence of development, and what we might expect in the way of avifaunal changes in the near future, we need to consider in more detail the relative availability, and the value to birds, of various Illinois habitats. IVe can evaluate a habitat both in terms of the number of birds it supports and the number of species it supports. If we arrange the habitats according to the number of breeding birds they supported, listing those with highest population densities first, the sequence for 1957-1958 was urban residential areas, marsh, shrub, orchard, hay crops, forest, grassland, oats, wheat, the row crops, and bare-field or plowed ground. The same habitats arranged in order of decreasing avifaunal variety were forest, shrub, orchard, urban residential areas, marsh, grassland, hay crops, oats, wheat, row crops, and bare-field or plowed ground.

Row crops comprised over a third of the state acreage in 1957-1958 and are unlikely to diminish in acreage in the foreseeable future. These crops have some value as foraging habitats for several species of birds, but there is no indication that species other than the horned lark depend significantly for their survival on this vast acreage.

Acreages of small grain crops, particularly oats, declined between 1930 and 1957, and most of the lost acreage of these crops went into row crops. The change represents a loss to the lllinois avifauna in terms of both numbers of birds and faunal variety. However, no species of bird is now entirely dependent upon the small grain habitats; these habitats form a kind of overflow area for species that usually attain higher population densities in hay crops and grassland.

If hay and grasslands disappear, part of the avifauna, particularly adaptive species 
such as the redwing, may survive principally in small grain fields. The redwing population, already somewhat in need of control, may expand even further in small grain habitats; small grain acreage in the coming years should not decline much below its present level.

Hay crops as a group, because they combine high population densities with large acreage, accounted in 1957-1958 for over 20 per cent of the state bird population, or at least $13,000,000$ birds (in contrast to $5,000,000$ or $6,000,000$ in 1907 $1909)$. In the 100 years before 1957 , cultivated hay was an expanding habitat, replacing principally wild hay and pastureland. The change tended to favor a few species, especially the redwinged blackbird and the dickcissel, and to increase the total number of birds in the state, while reducing the variety of common species in the areas in which the change took place. The change is continuing, and pastureland acreage is falling steadily, as livestock is being confined more and more to smaller feedlots. Coincidentally, the hay crops have been made more specialized. Much of the mixed hay acreage has given way to alfalfa, a poorer habitat for some of the prairie birds. In recent years, there has been some experimentation with other types of legume forage plants; if present hay types should ever give way to viny legumes, the hayfield avifauna would suffer greatly.

Prairie marshland, the habitat with the second highest population density of birds, had all but disappeared from the state by 1957-1958 (60,000 acres in contrast to 560,000 in 1907), but it accounted for over a million birds, including a variety of species not adapted to other habitats. In the immediate future, the remnant marshland may be safe, but, as the human population expands and the land available for food production declines, pressure will come for the elimination of marshes and other uncultivated open-field habitats. Marshland acreage could actually be increased in the state, especially near large reservoirs. Because of the specialized character of the fauna of marshland, conservationists should encourage both the development of new marshland areas and the preservation of the existing marshland.

The acreage of shrub-grown areas, which in 1957-1958 accounted for at least $2,000,000$ birds in the state, probably increased slightly between 1909 and 1957, but it may decline seriously in the coming decades. Land-use patterns over most of the state are more stabilized now than they were even 50 years ago. Most shrubgrown habitat constitutes a transitional habitat that usually gives way to forest and depends on change of one sort or another for its continued existence. Areas now in shrubs are growing into forest, and the principal sources of shrub land (deforestation as it was formerly practiced and retirement of cultivated fields) have been largely cut off. Forest will continue to be harvested, but the harvest methods now most widely used (not the same as when trees were removed over great tracts of land) do not lead to shrub land. The amount of Illinois shrub land maintained by edaphic or topographic conditions is negligible. In addition, the acreage of edge shrubs (fencerows and roadsides) and hedgerows is rapidly being greatly reduced. Edge shrubs and hedgerows may have a higher population density of birds than any other habitat in the state, and it is particularly regrettable that these habitats are being removed in an era when there is no shortage of foodproducing acreage. Though of very limited acreage (less than 100,000 acres), these edge habitats bring faunal variety to vast areas of open-field habitat where the fauna would otherwise be very limited; from the standpoint of efficient use of space for increasing populations of native species of birds, probably no easily ohtainable habitat is superior.

Fortunately, many shrub-inhabiting species can survive in forest understory, but there are some, such as the prairie warbler, Traill's flycatcher, and Bachman's sparrow, which require open shrub arrangements; few shrub-dwelling species attain such high population densities in forest as in shrub-grown areas. Shrub habitat, like marsh, is important to the Illinois avifauna, both for its high population densities and for the variety of specialized species it supports. Fortunately, land use in Illinois will probably never attain a state of equilibrium that will eliminate shrubgrown areas completely, but the day may come when some acreage will have to be 
managed specifically to create shrub habitat in order to maintain an interesting segment of our avifauna.

In little more than a century, orchard habitat in Illinois came in to existence, expanded to an area of over 300,000 acres that supported nearly 2,000,000 breeding birds, and then decreased drastically. 'Today, partly because of the limited acreage, the bird population (about 110,000) in orchards of the state is almost negligible and will probably remain so in the coming decades.

Forest, the woody habitat with the most varied fauna but lowest population density, will probably continue to increase slightly in acreage in the coming years. This increase will help to increase the state population of birds and maintain the variety of species. Like other natural habitats, forest may ultimately be endangered by the swelling human population with its needs for lumber, food, superhighways, dwelling areas, and trading centers.

The elm diseases, which have left dead trees in forests throughout much of Illinois, have created a special habitat that may for a short time favor population increases among certain picids and other cavity-nesting birds.

Urban residential areas, which now boast a higher bird population density than any other habitat except edge, occupied an almost inconsequential acreage only 100 years ago. By 1909, urban area in the state was up to 350,000 acres and accounted for about $3,000,000$ birds ( 6 per cent of the state population); by 1958 , the area exceeded 800,000 acres, accounting for nearly $8,000,000$ breeding birds (13 per cent of the state population), and was growing at an ever-increasing rate. The end of this growth is not in sight, and, because urban areas are claiming an increasingly important role in the development of the Illinois avifauna, this habitat deserves careful and intensive study. Most of the state population of introduced problem species (starling, house sparrow, and rock dove) is produced in residential habitat. To some extent, these introduced species are probably effecting limitations on native species in the urban residential avifauna, but, even if the exotic species were not present, the urban fauna would be restricted in variety. The house sparrow population appears to have reached the saturation point, at least in old urban areas, but, because the urban residential habitat is expanding, the sparrow population will increase. The starling also should continue to increase in numbers; its population may not yet have reached the saturation point in any habitat.

To date, conscious efforts to control sparrow and starling populations by planned elimination of their nesting sites have been negligible. The "gingerbread" house and similar architectural patterns of past decades, because they offered a multiplicity of nesting and roosting sites, were probably especially favorable to the sparrow and starling. Few native species make use of human dwellings; therefore, building design offers an important and specific technique for the control of the three introduced problem species. The common practice by realtors of planting fast-growing softwood trees in new housing additions probably favors some native species of birds. The practice also favors the starling. Landscape architecture offers another effective avenue of control for problem species. From an economic standpoint it is, of course, not feasible to quickly supplant established housing and landscape features, but at present the acreage of residential habitat in Illinois is expanding greatly, and some effort should be made to at least study the possibilities of planned control of problem bird species by building and landscape design.

Residential habitat itself is changing in character. The newly developing large acreage of suburban housing will, for some years, have limited arboreal habitat for birds, and the house sparrow will probably dominate the early stages of suburban birdlife. The absence of large trees in new suburbs and the low-level dimensions of many suburban houses should discourage starlings to some extent in these areas. The bird-attracting potential of new housing and landscape designs remains to be determined. Because of the absence of large trees, grackles, flickers, crested flycatchers, and some of the other prominent species of older residential areas will be largely missing from the suburbs for some time. Developing small trees and shrubbery should favor some native species. The robin, which seems to have be- 
come dependent on residential habitat, and the mourning dove should increase their populations.

Before 1980, there will probably be over 1,000,000 acres of urban residential habitat in the state, with a bird population numbering over 10,000,000 and including as miny as $6,000,000$ house sparrows and starlings in this habitat alone. Properly managed, this acreage could be made more pleasant for its human inhabitants and attractive to a variety of desirable native species of hirds. Urban and suburban business districts, which are beginning to absorb a significant fraction of the state acreage, represent an almost total loss as habitat for native hirds (except nighthawks), but they support large populations of the three introduced species.

Road and highway surfaces and railroad trackage also represent lost habitat acreage for birds. We have estimated that about 600,000 acres of Illinois land were covered by road (surfaces only) in 1910, and over $1,100,000$ in 1960. More acreage will go under concrete as highways are widened and work on four- to eightlane interstate routes is expanded. As many as $1,500,00$ acres may thus be utilized in the state by 1980 . Along the margins of this highway system is a grassy roadside cover that in 1960 occupied nearly $+00,000$ acres along primary roads alone. This habitat-useful to a few native species of birds, notably meadowlarks -should increase in acreage in the coming decades, especially along interstate routes. This road-edge habitat warrants special study for its value to birds.

An unknown in relation to the expansion of these urban and highway areas is where the acres will come from; that is, what present habitats will be reduced to make room for the expansion? The probability is that most of the acreage for the expansion will come from open cultivated fields, particularly row crops, which would represent little loss to birds; in some areas, in the southern zone especially, some forest or shrub acreage may fall to the burgeoning cities and highways, and this would represent a definite loss.

The habitat changes discussed above had a profound effect on the Illinois avifauna, but it is difficult to understand some of the observed population changes, and probably it is misleading to generalize about them. It is easy to see that the reduction in acreage of orchards, a habitat notably concentrated in the southern zone, could have reduced the orchard oriole population in this zone from about 400,000 birds in 1907-1909 to 100,000 in 19571958. On the other hand, it is difficult to understand why the blue jay population should have lost over half a million birds in the southern zone in a period when woody habitats were expanding. It is reasonable to assume that the introduction of the starling may have played some role in the decline of such cavity-nesting species as the red-headed woodpecker and flicker and that the expansion of woody habitats had a bearing on the increase in the indigo bunting. But what of the virtual elimination of the lark sparrow, which in 19071909 had a population in the southern zone of at least 300,000 birds? Here, for the most part, we can only point to the population changes; we cannot explain them. There is room for speculation and there are many factors to consider-climatic changes, habitat changes, competition, genetic vigor, and others-but all paths of speculation lead inevitably to more and more questions and the ultimate realization that each of these species needs special, detailed study. We should not forget, either, that the apparent population changes may represent transient conditions - normal fluctuations or temporary setbacks from which any or all of the species mentioned may come back in force.

Among the factors that complicate the interpretation of apparent population change in a given species is a lack of precise information on the relative importance of various habitats to that species. The census data revealed that few species of Illinois birds spend the day solely in only one or two habitats. Even some forest species spend time in open fields, figs. 31 and 32.

We have hypothesized that the high bird population of a few relatively stable natural habitats characteristic of primitive Illinois declined in the 19 th and early 20 th centuries as the natural cover gave way to the agricultural and other managed habitats that came with white settlement and that, although for most of these new Illinois habitats there was no real 
avifauna, an agriculture-adapted avifauna was probably beginning to develop even as agriculture came to dominate the land.

When the Illinois bird population reached its low we cannot say; by 19071909 , at a level of $61,000,000$ birds, it may have been climbing. In the next 50 years, despite waning populations in a number of species, especially inhabitants of savanna-type areas, the total Illinois bird population remained about the same, principally because of a new introduction, the starling, and expanding populations in the relatively few species that comprised the avifauna for managed habitats. Be- cause of these species the state population will probably increase in the coming decades. Even the redwing and horned lark populations have probably not yet reached saturation levels, and there may ultimately be increased use of croplands by a few other species.

Our prognostication that the number of birds in Illinois will increase in coming decades is based primarily on a consideration of changes in habitat and the response of a few species to these changes. In truth, we do not even begin to know all of the factors that will affect future populations of Illinois birds.

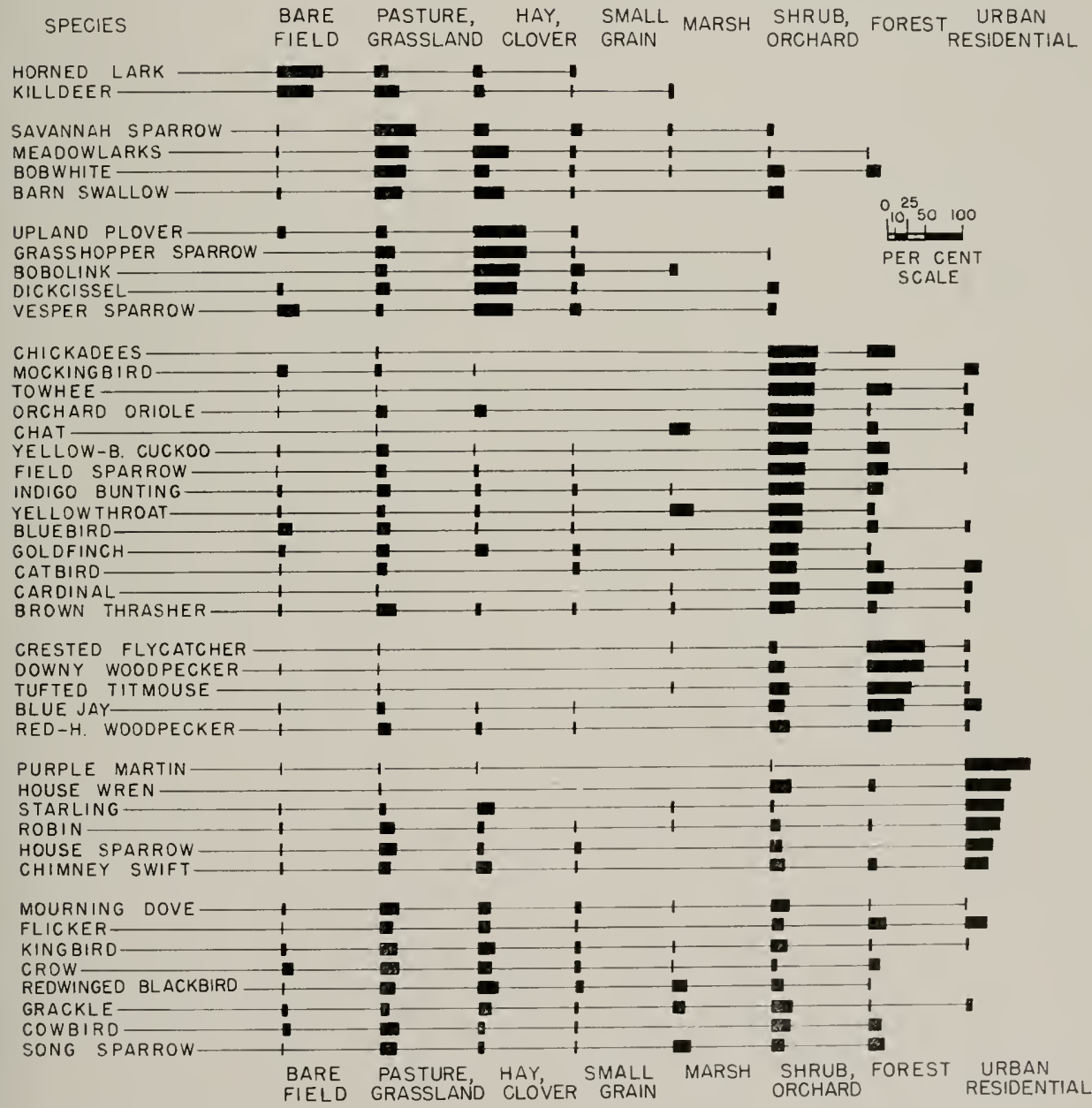

Fig. 31.-Habitat preferences of common species of Illinois birds in summer as indicated by the population density of each species in each habitat. Each black bar represents the relative density of a given species in a given habitat; the sum of the relative densities for each species is 100 per cent. Data are from all zones of the state and from all summer censuses. 


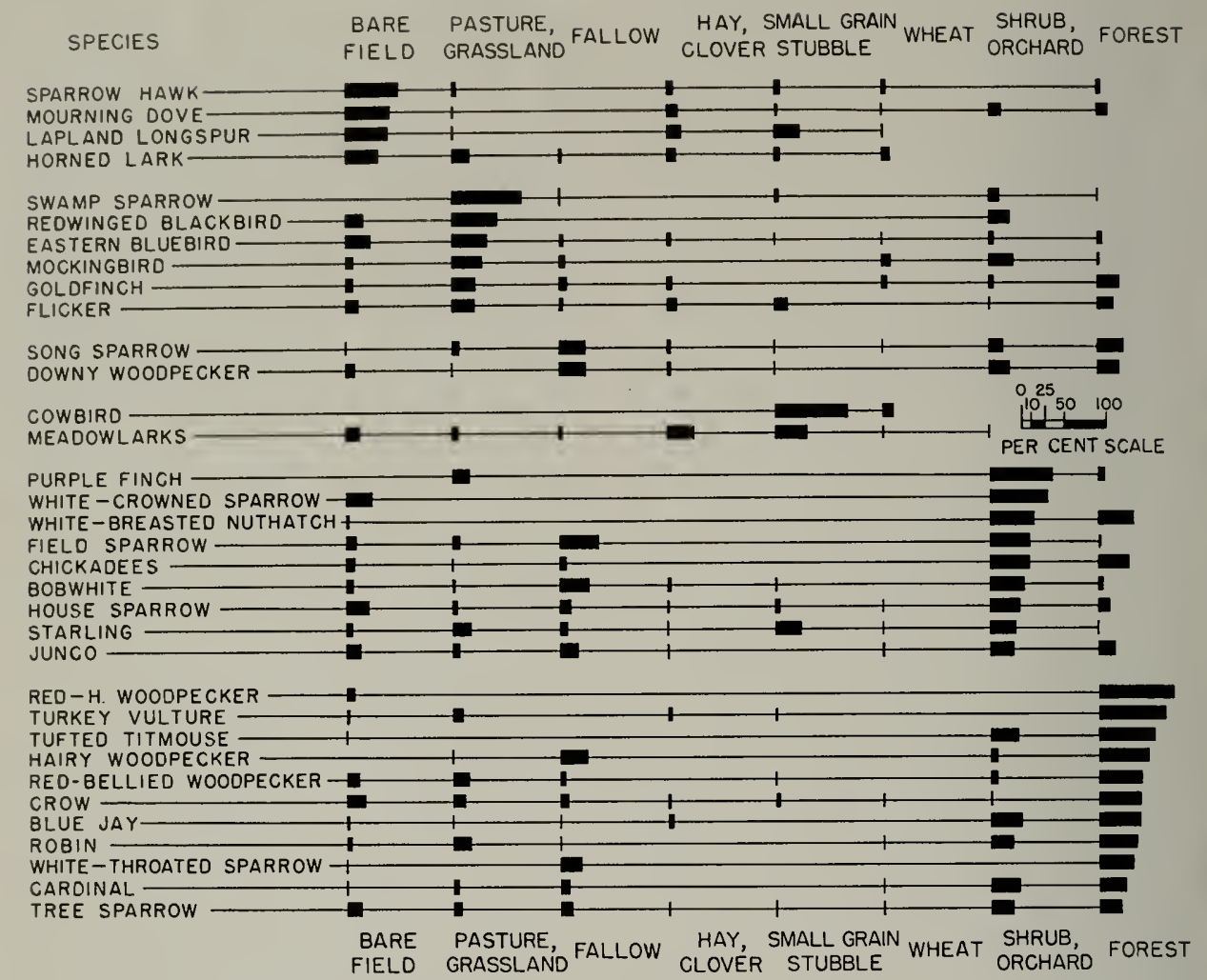

Fig. 32.- Habitat preferences of common species of Illinois birds in winter as indicated by the population density of each species in each habitat. Each black bar represents the relative density of a given species in a given habitat; the sum of the relative densities for each species is 100 per cent. Data are from all zones of the state and from all winter censuses.

To the multiplicity of factors involved in this extremely complicated subject, man has, in recent years, added to the complexity. In a sense, we have entered into a new era characterized by the widespread, regular application to the land of potent chemicals-insecticides, herbicides, and fertilizers. The acreage of Illinois cornland treated with chemicals for control of subterranean insects expanded from about 780,000 in 1958 (the last year of the second census period) to more than 3,500,000 acres in 1962 (Anon. 1963a:1). As we consider the increasing acreage of corn, soybeans, and other crops that are being treated with insecticides and herbicides, and the increasing acreage of roadside and other vegetation that is being killed with herbicides, we ask ourselves if we are not rapidly approaching the time when most of Illinois will be treated with toxicants of one sort or another.
We are only beginning to understand some of the effects of these chemicals on birds. Among the most important research needs in the state are detailed, carefully planned, and controlled studies of the effects of pesticides (insecticides and herbicides) on birds, their diets, their reproduction, their survival. We have suggested that, with the increased use of insecticides in orchards, population densities of certain species were reduced in this habitat. Mortality of birds as a result of applications of pesticides in a wide variety of habitats and geographic areas has been described and discussed by many authors (including DeWitt \& George 1959; Scott, Willis, \& Ellis 1959; Anon. 1962). There is ample evidence that this mortality results from both direct and indirect (through the food chain) intoxication (Bernard 1963:170, 188-90). Nesting success in a pesticide-treated area may be 
greatly reduced because of loss of natural insect foods, or the intoxication of juvenile birds or adults (Hanson 1952:305S; DeWitt \& George 1960:8-9; and others). IVe are still short of data on the cumulative effects of sublethal doses of pesticides on individual birds and the longterm effects on whole populations. Particularly pertinent here is the evidence that certain widely used chlorinated hydrocarbons reduce reproductive capability in birds (DelVitt 1955:676; 1956:865-6; Anon. 1962: +5-7).

What effect the widespread use of insecticides and herbicides in the various habitats will have on the future populations of Illinois birds remains to be seen. Because cultivated lands and urban residential areas are the habitats that are being most widely and regularly treated with pesticides, the very species of birds that have been increasing their populations in recent years may, in coming generations, be the species that decline.

\section{Man and the Avifauna}

Whatever the genetic or ecological characteristics of the species involved, it is abundantly clear that man, among the various forces that shape our fauna, is the dominant force of change. In his use of the land for food production, commercial enterprises, home building, and other purposes, he selects (albeit unwittingly) for some species of birds and perhaps inevitably against others.
In the history of a fauna, 50 years is an extremely brief period, and the coming years will probably accentuate the loss in avifaunal variety, even though the number of birds increases. The most unfortunate aspect of man's domination of the land is not that he changes the environment but that he changes it so widely so quickly. Species evolution requires time. Natural cataclysms may alter habitats quickly but not widely, or widely but not quickly. It is man who combines the two, who changes the face of the earth not in millennia but in decades.

For the most part, man has utilized the land without regard for the natural fauna. In North America, conscious management of bird populations, except those of a few game species, has been negligible. Yet for the past several decades man has been unwittingly manipulating bird populations on a wholesale scale. His domination has reached a critical and fearful level. Some obligation must go with this domination. Man has reached the stage when he must consider, in his manipulation of the environment, more than just his own primary needs. If there is to be a varied and interesting fauna for future generations to know, then management of the land must extend beyond human needs to the basic requirements of the fauna. Our lack of knowledge is the overriding deterrent to this type of management, but not the only one, and education of the public will have to follow the much-needed research. 


\section{LITERATURE CITED}

Allen, J. A.

1890. Eastward range of the western meadowlark. Nuttall Ornith. Club Bul. 5:53-4.

American Ornithologists Union

1957. Check-list of North American birds. 5th ed. American Ornithologists' Union. 691 pp.

Anonymous

1900- Christmas bird count. (A series of reports on annual Christmas bird counts, as pro-

1960. posed in Bird-Lore 2(6): 192. Reports published in Bird-Lore, Audubon Magazine, Audubon Field Notes, various issues and pages.)

1832. Abstract of the returns of the Fifth Census. 22nd Congress, 1st Session, House of Representatives Document 269. 51 pp. Duff Green, Washington, D). C.

[1936.] Illinois crop and livestock statistics. Ill. Dept. Ag. Circ. 438. 341 pp.

1962. Effects of pesticides on fish and wildlife: a review of investigations during 1960. U. S. Fish and Wildlife Service Circ. 143. 52 pp.

1963. Subterranean insects. The Illinois Natural History Survey Reports, February, 1963. $+\mathrm{pp}$.

Baker, Mrs. H. A

1955- Tivo hay fields and grazed creek pasture. [Series of articles appearing under this

1961. and similar titles in annual breeding-bird census reports.] Audubon Field Notes, $1955,9(6):+23-4 ; 1956,10(6): 427-8 ; 1957,11(6): 4+7 ; 1958,12(6): 450 ; 1959$, $13(6):+67-8 ; 1960,14(6):+98-9 ; 1961,15(6): 511$.

Barnes, R. M.

1912. Breeding birds of Marshall Co., Ill. Oologist 29:325-\$.

Barrows, Walter B.

1889. The English sparrow (Passer domesticus) in North America, especially in its relations to agriculture. U. S. Biol. Surv. Bul. 1. (Published as U.S. Dept. Ag. Div. Econ. Ornith. and Mammal. Bul. 1.) $405 \mathrm{pp}$.

Bernard, Richard F.

1963. Studies on the effects of DDT on birds. Mich. State Univ. Mus. Biol. Ser. 2(3) :15592.

[Chapman, Frank M.]

1900. A Christmas bird-census. Bird-Lore 2(6):192.

Conover, John $\mathrm{H}$.

1953. Climatic changes as interpreted from meteorological data. Chap. 18, pp. 221-30, in Climatic change: evidence, causes, and effects; Harlow Shapley, ed. Harvard University Press, Cambridge. $318 \mathrm{pp}$.

Cooke, Wells W.

1915. Preliminary census of birds of the United States. U. S. Dept. Ag. Bul. 187. $11 \mathrm{pp.}$

1916. Second annual report of bird counts in the United States, with discussion of results. U. S. Dept. Ag. Bul. 396. 20 pp.

DeWitt, James B.

1955. Effects of chlorinated hydrocarbon insecticides upon quail and pheasants. Ag. and Food Chem. 3(8):672-6.

1956. Chronic toxicity to quail and pheasants of some chlorinated insecticides. Ag. and Food Chem. 4(10):863-6.

DeWitt, James B., and John L. George

1960. Bureau of Sport Fisheries and Wildlife pesticide-wildlife review: 1959. U. S. Fish and Wildlife Serv. Circ. 84. (Special scientific report: wildlife.) $36 \mathrm{pp}$.

Eifrig, C. W. G.

1927. Notes from the Chicago area. Auk 44(3):431-2.

Ewing, J. A., in charge

1959. Illinois agricultural statistics, annual summary 1959. Illinois Co-operative Crop Reporting Service. Springfield. $7+$ pp.

Forbes, Stephen A.

1907. An ornithological cross-section of Jllinois in autumn. 1ll. Lab. Nat. Hist. Bul. $7(9): 305-35$.

1908. The mid-summer bird life of Illinois: a statistical study. Am. Nat. 42:505-19.

1913. The midsummer bird life of Illinois: a statistical sturly. Ill. Lab. Nat. Hist. Bul. $9(6): 373-85$.

Forbes, Stephen A., and Alfred O. Gross

1921. The orchard birds of an lllinois summer. Ill. Nat. Hist. Surv. Bul. 14(1):1-8 + pls. I-VI.

1922. The numbers and local distribution in summer of Illinois land birds of the open country. III. Nat. Hist. Surv. Bul. 14(6): 187-218 + pls. XXXV-LXX.

1923. On the numbers and local distribution of Illinois land birds of the open country in winter, spring, and fall. Ill. Nat. Hist. Surv. Bul. 14(10):397-+53.

Graber, Richard R., and Jack S. Golden

1960. Hawks and owls: population trends from Illinois Christmas counts. Ill. Nat. Hist. Surv. Biol. Notes 41. 24 pp. 
Hagan, William $\mathbf{T}$.

1958. The Sac and Fox Indians. University of Oklahoma Press, Norman. 287 pp.

Hancock, Joseph L.

1888. Impeded migration and destruction of birds at Chicago. Auk 5(4): $432-4$.

Hanson, Harold C., and Charles W. Kossack

1957. Weight and body-fat relationship of mourning doves. Jour. Wildlife Mgt, $21(2)$ : 169-81.

1963. The mourning dove in Illinois. Ill. Dept. Cons. Tech. Bul. 2. 133 pp.

Hanson, William R.

1952. Effects of some herbicides and insecticides on biota of North Dakota marshes. Jour. Wildlife Mgt. 16(3):299-308.

Hickey, Joseph J., Editor

1937. Bird-Lore's first breeding-bird census. Bird Lore 39(5):373-86.

Hicks, Lawrence E.

1935. Small birds are not decreasing! Bird-Lore $37(5): 303-9$.

James, Douglas

1962. Winter 1961-62: dominated by movements of boreal birds and marked by still low numbers of eastern bluebirds. Audubon Field Notes 16(3):306-11.

Kendeigh, S. Cliarles

1944. Measurement of bird populations. Ecol. Monog. 14(1):67-106

1954. Oak-maple forest and forest edge (in Eighteenth breeding-bird census). Audubon Field Notes $8(6): 370-1$.

1960. Oak-maple forest and edge (in Twenty-fourth breeding-bird census). Audubon Field Notes 14(6): 502 .

Kendeigh, S. Charles, and Richard D. Brewer

1956. Oak-maple forest and forest-edge (in Twentieth breeding-bird census). Audubon Field Notes $10(6): 434$

Kendeigh, S. Charles, Marshall B. Eyster, and Robert K. Stubbs

1950. Oak-maple forest and forest-edge (in Fourteenth breeding-bird census). Audubon Field Notes $4(6): 300$.

Kendeigh, S. Charles, and Nancy Joen Forsyth

1959. Oak-maple forest and edge (in Twenty-third breeding-bird census). Audubon Field Notes $13(6): 472-3$.

Kendeigh, S. Charles, and Walter Gillespie

1955. Oak-maple forest and forest-edge (in Nineteenth breeding-bird census). Audubon Field Notes $9(6): 431$.

Kendeigh, S. Charles, Douglas James, and Charles Weise

1952. Oak-maple forest and forest-edge (in Sixteenth breeding-bird census). Audubon Field Notes $6(6): 310-1$.

1953. Oak-maple forest and forest edge (in Seventeenth breeding-bird census). Audubon Field Notes $7(6): 3+7$.

Kendeigh, S. Charles, Robert V. Kennedy, George W. Cox, George C. West, and Walter L. Gillespie

1957. Oak-maple forest and forest edge (in Twenty-first breeding-bird census). Audubon Field Notes $11(6): 452-3$

Kendeigh, S. Charles, and Robert K. Stubbs

1951. Oak-maple forest and forest-edge (in Fifteenth breeding-bird census). Audubon Field Notes $\mathbf{5}(6): 324$

Kendeigh, S. Charles, and George C. West

1958. Oak-maple forest and edge (in Twenty-second breeding-bird census). Audubon Field Notes $12(6): 455$.

King, D. B., and R. K. Winters

1952. Forest resources and industries of Illinois. Ill. Ag. Exp. Sta. Bul. 562. 95 pp.

Livesay, Ann

1951. The past speaks to you. Ill. State Mus. Story of Ill. Ser. 7. 32 pp.

Musselman, T. E.

1941. Bluebird mortality in 1940. Auk 58(3): 409-10.

Rand, A. L.

1956. Changes in English sparrow population densities. Wilson Bul. 68(1):69-70.

Ridgway, Robert

1915. Bird-life in southern Illinois. IV. Changes which have taken place in half a century. Bird-Lore $17(3): 191-8$.

Ross, R. C., and H. C. M. Case

1956. Types of farming in Illinois: an analysis of differences by areas. Ill. Ag. Exp. Sta. Bul. 601. 88 pp.

Scott, Thomas G.

1958. The ornithologist's responsibility to the future. Wilson Bul. $70(4): 385-93$.

Scott, Thomas G., Yuell L. Willis, and Jack A. Ellis

1959. Some effects of a field application of dieldrin on wildlife. Jour. Wildlife Mgt. $23(4)$ : 409-27. 
Slıaw, Samuel P., and C. Gordon Fredine

1956. Wetlands of the Cnited States: their extent and their value to waterfowl and other wildlife. I'. S. Fish and Wildlife Serv. Circ. 39. 67 pp.

Smith, Harry R., and Paul W. Parmalee

1955. A distributional check list of the birds of 1llinois. Ill. State Mus. Pop. Sci. Ser. 4. $62 \mathrm{pp}$.

Stone, George J.

1950. Breeding-bird census. Audubon Field Notes 4(2):185-6.

Temple, Wayne C.

1958. Indian villages of the Illinois country. Historic tribes. Ill. State Mus. Sci. Papers 2(2). 218 pp.

U.S. Bureau of the Census

1913. Thirteenth cellsus of the United States taken in the year 1910. Vol. V, Agriculture, 1909 and 1910. 977 pp. U. S. Government Printing Office, W'ashington, D. C.

1961. U. S. Census of Agriculture: 1959. Vol. I, Counties. Part 12, Illinois. 255 pp. U. S. Government Printing Office, Washington, D. C.

Wetmore, Alexander

19+0. A check-list of the fossil birds of North America. Smithsn. Inst. Misc. Collect. 99(t). $81 \mathrm{pp}$.

Yeatter, Ralph E.

19+3. The prairie chicken in Illinois. Ill. Nat. Hist. Surv. Bul. 22(t):377t+16. 


\section{$I N D E X$}

In this index, page numbers referring to figures and tables are in italic type; page numbers for principal references are in boldface type. Of necessity, variation occurs in some of the terms indexed. For example, cornfield in the index may sometimes refer to corn in the text; slate-colored junco in the index may refer to junco in the text. Shrubs in one place may be synonymous with shrub-grown area in another.

For certain sections dealing with bird species and with habitats, inclusive pages for each are given in boldface type; for example, Robin, 485-6, Pasture, 408-12. Within the inclusive pages for any of these items, no text references to subdivisions of the items are indexed; for example, the acreage of pasture and the bird populations in pasture as given in the text on page 409 are not indexed; however, the acreages of pasture shown in the graph on page 388 and mentioned on pages 440 and +57 are indexed under Pasture, as are the bird populations in pasture mentioned on pages 440,441, and 457 ; dickcissel as mentioned on page 409 is indexed under the entry Dickcissel as a species in pasture.

Common and scientific names of birds encountered in this study are listed in table 55 , pages 459-62; the index includes references to the common but not the scientific names on these pages.

\section{A}

Acreage censused (see also under each habitat), $396,4+3$

Acreage data, sources of, $387-8$

Airfields (airports), $++2,+58$

Alfalfa, $386,+14,416,418,420,421-2,438,43 \delta$, $439,439,468,469,472,477,478,479,484$ $486,487,488,489,490,491,492,493,495$, $496,497,500,510$

acreage censused, 396,723

acreage in state, $388,4+1$

avifauna of, 423

common species in, 427

statistical data on populations in, 423

Annotated list of common bird species, 463-500

Avifauna, specific changes in, 503-1

\section{B}

Bare-field or bare-ground habitat, 397, 401, $438,439,497,509,513,514$

Barley, $4+40,+48$

acreage censused, 396

Beans (see also Soybeans), 408, 471, 478, 482

Bird populations (see also individual species) annotated list of common species, 463-500 avifaunal differences between censuses, 463 of common species, 1909 and 1957, 507

comparison of data for summer habitats, $437-10$

comparison of data for winter habitats, 4536

density in three zones, +42-3, +57-8, 458

loss between 1909 and 1957,505

number of birds eliminated by forest removal, 502

number of birds in summer habitats, 438-9 number of birds in winter habitats, 456 number of common species, 508

number of species in summer habitats, 43940

number of species in winter habitats, 456 previous to $1800,501-2$

statewide, 513

staterride summer, 440-3, 503

statewide winter, $456-8,508$

in summer habitats, 396-443

variations in statewide, $4+2$

variations in summer and winter, 392-3

in winter habitats, 443-58
Bird species

account of, 458-500

encountered in strip censuses, 459-62

number of identified, 458

Bittern, American, 459, 463

as species in marsh, 425

Bittern, least, 459,463

as species in marsh, 425

Blackbird spp., 509

Blackbird, Brewer's, 461, 463

range extension, 509

as species in corn, 398; hay, 417; pasture, 411

Blackbird, redwinged, 461, 462, 490, 490-1, $495,508,510,513$

habitat preferences, 513,517

population (statewide), 504

population for all habitats in study, 507

as species in alfalfa, $422,423,424$; clover, 420, 421, 422, 427; corn, 397, 398, 400, 400, 460 ; fallow fields, 414, 415; forest, 432 , 455; grassland, 412,413 ; hay, 389-90, $390,416,417,418,419$, 427; marsh, 424 , 425 ; oats, $40 \dot{+}, 405,407$; orchard, 429, 430 , 430 ; pasture, $409,410,412,412,450$; plowed fields, 403; shrubs, 424, 425, 426 , $427,428,454$; soybeans, 401, 402, 447 ; wheat, 406, 407,408 ; woodland, 737

Blackbird, rusty, 461,463

as species in corn, $4+6$

Blackbird, yellow-headed, 461, 463

range extension, 509

as species in fallow fields, 415; marsh, 425

"Blackbirds," 491

Bluebird, eastern, 393, $761,462,485,486$

habitat preferences, $513,51 . t$

as species in clover, 421 ; corn, $398,700,7+5$, +6 ; fallow fields, 415,451 ; forest, 432 , 455; hay, 418 , 453; marsh, 425; oats, 405 ; pasture, 410,450 ; plowed fields, 403 ; shrubs, 427,457 ; small grain, 48 ; wheat, 479; woodland, 392,434

Bluegrass, $409,430,451$

Bobolink, 761, 489

habitat preferences, 513

range extension, 509

population for all habitats in study, 507

as species in alfalfa, 423,424 ; clover, 420 , $421,422,427$; corn, 398 ; grassland, 113 ; 
hay, $389,390,+17,+18,+19,+27$; marsh, $+24,+25$; oats, $404,105,407$; pasture, 410 ; shrubs, 727

Bobwhite, $759,+62,466-7$

habitat preferences, 513,514

population for all habitats in study, 507 as species in alfalfa, 423 ; corn, $398,4+5,4+6$, +46 ; clover, $420,+21,422$; fallow fields, $+15,+51,+52$; forest, $432,+53,455$; grassland, 413 ; hay, $417,419,+52,453$; oats, 405 ; orchard, 429,430 ; pasture, 410, 450; plowed fields, 703 ; shrubs, 426, 42i, 453, 75t; small grain, $47 S$; soybeans, 402 ; wheat, 107

Breeding species, definition of, 389

Bromegrass, $+16,+20$

Bunting, indigo, $762,463,494-5,512$

habitat preferences, 513

population for all habitats in study, 507

as species in alfalfa, 423 ; clover, 721 ; corn, $39 S$, fallow fields, 415 ; forest, 432,435 ; grassland, 413 ; hay, 417 ; oats, 405 ; orchard, $429,430,430$; pasture, 410 ; plowed fields, 403 ; shrubs, $424,425,426,427,42 S$; soybeans, 702 ; wheat, 406,407 ; woodland, 134

Bunting, snow, $762,+63$

as species in small grain, 448

\section{C}

Cacti, frontispiece

Caprimulgus spp. in forest, 433

Cardinal, $+53,+62,462,493-4$

habitat preferences, 513,514

range extension, 501,509

as species in alfalfa, $423 ; \operatorname{cor} n, 398,445$, $4+6$; fallow fields, $415,451,452$; forest, $+32,+35,436,+53,455$; hay, 418 ; oats, 405 ; orchard, 429, 430, 430; pasture,

$410,450,+52$; shrubs, $424,426,427,428$, $43,45+$; urban residential areas, 436 ; wheat, 407, 449; woodland, 392, 434

Catbird, $460,463,483-4,484,508$

habitat preferences, 513

as species in corn, 398 ; forest, 432 ; hay, 418; marsh, 425 ; oats, 405 ; orchard, 429, 430 ; pasture, 410 ; shrubs, $424,426,428$; urban residential areas, $436,437,437$; wheat, 407 ; woodland, 434

Cattails, $42+, 504$

Cemeteries, $4+2,458$

Census, breeding-bird, in hayfields, 389-91

Census, strip

area, size of adequate, $386-7$

counties included in, 385,386

data on areas of different sizes, 387

dates of, $385-6$

description of method, 383-9

evaluation of method, 389-93

zones, boundaries between, 386

zones, how defined, 388

Chat, yellow-breasted, 461

habitat preferences, 513

as species in fallow fields, 415 ; forest, 432 ; orchard, 429; pasture, +11 ; shrubs, +24 , $426,42 \bar{i}, 428$; woodland, 434

Chickadee spp., $388,460,481-2,482,483$

habitat preferences, 513,514

as species in corn, $445,446,446$; fallow fields, 451 ; forest, $432,435,+53,+55$; hay, 453 ; pasture, 411,450 ; plowed fields, $4+1$; shrubs, $426,+28,45 t ;$ woodland, $392,43 t$ Chickadee, black-capped, $388,460,481-2,482$

Chickadee, Carolina, 388, 460, 481-2, 482

range extension, 509

as species in orchard, $429,+30 ;$ shrubs, 427

Chicken, greater prairie, $759,463,+66$

as species in clover, 420,421 ; corn, 398 ; hay, 418; pasture, 411 ; wheat, 707

Chlorinated hydrocarbons, 515

Clover (clover fields), 418-21, 422, 468, 469, $+72,+73,513,517$

acreage in state, 388

Clover, Ladino, 420

Clover, red, $389,414,416,418-20,+21,+22,430$, $+38,438,+39,439,+66,+68,+69,+70,+72$, $+75,+76,+77,+79,+80,+84,+85,+86,+87$, $488,+89,+90,+91,+92,493,+95,+96,+97$, $+99$

acreage censused, $396,420,421$

avifauna of, 421

common species in, 422, 427

statistical data on populations in, 420

Clover, sweet, $389,41+6,+18,420-1,438,43 \delta$, $+39,+69,+72,+77,478,479,480,484,489$, $490,+91,+92,+93,495,496,+99$

acreage censused, 396,422

avifauna of, 422

Common names of birds, list of, 459-62

Common species of birds

breeding populations of, 1909 and 1957, 507 definition of, 387

habitat preferences, $513,51 \mathrm{t}$

Control of problem bird species, 511

Coot, American, 459, +63

as species in marsh, 425

Cornfield (corn), frontispicce, 383, 386, 396, $397-401,399,401,405,406,408,438,438$, $439,439,4+0,4+3,443-7,444,4+7,+48,450$, $+52,+56,+65,+66,+67,+68,+69,+70,+71$, $+72,+73,474,475,+76,+77,+78,+79,+80$, $481,482,483,484,485,486,487,488,490$, $491,+92,+93,+95,496,497,498,500,502$, 514

acreage censused, $396,397,398-9,4+3,446$

acreage in state, $388,4+0,445,456$

avifauna of, $398-9,445,446$

bird populations in, 392, 392, 442

common species in, $397,400,400,417$

statistical data on populations in, 397

Cowbird, brown-headed, 461, 462, 492-3

habitat preferences, 513,514

population for all habitats in study, 507

as species in alfalfa, 423 ; clover, 420,421 , 422 ; corn, 398 ; fallow fields, 415 ; forest, 432 ; hay, 417,424 ; grassland, 413; marsh, 425 ; oats, 404, 405; orchard, 429 ; pasture, 409 , 410; plowed fields, 403; shrubs, +24, $426,427,428,454$; small grain, 448; soybeans, 402 ; urban residential areas, 436 ; wheat, 40\%, 449; woodland, 434

Creeper, brown, 460

as species in forest, 455 ; woodland, 392

Crow, common, $460,+62,480-1$

habitat preferences, 513,514

population for all habitats in study, $50 \mathrm{~T}$

as species in alfalfa, 423; clover, 421, 422; corn, 398, 400, 445, 4+6, 476; fallow fields, 
415,451 ; forest, $432,+35,+53,455$; grass land, 413 ; hay, $417,419,453$; marsh, 425 ; oats, 405 ; orchard, 429 ; pasture, 110,450 +52; plowed fields, 403 ; shrubs, 426,454 . small grain, 448, 449 ; soybeans, 447 ; wheat, 407, 449; woodland, 392, 434

Cuckoo spp., 472

Cuckoo, black-billed, 459, 472

as species in forest, 433 ; pasture, 411 ; plowed fields, 403

Cuckoo, yellow-billed, 459, +63, 472, 505

habitat preferences, 513

as species in corn, 399; fallow fields, 415 ; forest, 432; hay, 418; marsh, 425 ; orchard, 429 ; pasture, 110 ; shrubs, 426,427 ; wheat, 407

\section{D}

Dendrocopos spp. in forest, 433, 455; woodland, 392, 434

Dickcissel, 462, 463, 495, 510

habitat preferences, 513

population for all habitats in study, $50 \mathrm{~T}$

as species in alfalfa, 422,423 ; clover, 420 , $421,422,424$; corn, 398; fallow fields, 414,415 ; grassland, 413; hay, 389, 390, 416, 41\%, 418, 419; oats, 405; orchard, 429,430 ; pasture, 409,410 ; plowed fields, 403 ; shrubs, 426, 428 ; soybeans, 402 ; wheat, $406,407,408$

Discussion, 500-15

Dove, mourning, 453, 459, 462, 469-72, 505, 508,512

habitat preferences, 513,517

population for all habitats in study, 50 t

as species in alfalfa, 423,424 ; clover, 721 , 422 ; corn, 392, 397, 398, 400, 445, 4+6, 446 ; fallow fields, $414,415,451$; forest, $432,+35,455$; grassland, 413 ; hay, $41 \%$, $419,424,453 ; \mathrm{marsh}, 425 ;$ oats, 404, 405 ; orchard, $429,430,430$; pasture, 410 ; plowed fields, 403 ; shrubs, $+24,426$, $427,428,454$; small grain, 448 ; soybeans, 401 , 402, 47\%; urban residential areas, 436 , 437 ; wheat, $406,407,408,479$; woodland, 734

Dove, rock, $759,463,511$

as species in commercial urban areas, ++1 ; urban residential areas, $436,437,437$

Drainage ditches, $479,487,490,491,492,494$, $+95,+99$

Duck, black, $459,+63$

Duck, wood, 459,463

Eagle, bald, $459,+63$

\section{E}

Eagle, golden, 459,463

as species in forest, 455

Edge (edge shrub, road edge; see also Shrub habitat and Shrub-grown area), $400,+12$, $426,+28,+38,+45,4+6,+52,+56,+64,+66$ $467,469,+71,+72,+73,+76,+78,+79,+80$, $481,+82,483,+84,+85,486,487,488,+90$, $+91,+92,+93,+94,+95,+97,+98,499,502$. $505,506,510,511,512$

acreage in state, $++2,510$

bird populations in, ++2

Egret, common, $459,+63$

as species in forest, 433; grasssland, 413
Elm diseases, 511

Evolution, 501, 502, 503, 515

\section{$\mathrm{F}$}

Fallow fields, $412,413-4,424,438,438,439$, $439,4+3,474,452,456,465,466,467,468$, $469,+70,+71,+72,+73,+74,+75,+76,477$, $479,480,482,483,484,486,487,488,490$ $491,492,493,494,495,496,+97,498,499$, 514

acreage censused, $396,417,415,4+0,4+3$, 451

acreage in state, 388,457

avifauna of, $\$ 15,+51$

bird populations in, $4+0,457$

common species in, 417

statistical data on populations in, 417

Farm and crop acreage, various years, 502

Fencerow, 425, 510

Fertilizers, 514

Finch, purple, 462

habitat preferences, 514

as species in forest, 455 ; pasture, 450 ; shrubs, $45 t$

Flicker, yellow-shafted, $460,462,473-4,+74$, $+75,505,511,512$

habitat preferences, 513,514

population (statewide), 503

population for all habitats in study, 507

as species in alfalfa, 423 ; clover, $t 21$; corn, $398,400,4+5,446$; fallow fields, 415,451 ; forest, $432,+36,+53,455$; grassland, 413 ; hay, $417,419,453$; oats, 405 ; orchard, 429 $+30,430$; pasture, 410,450 ; plowed fields 403, 477 ; shrubs, 42 $\%$, 454; small grain, 48 ; urban residential areas, 436 ; woodland, $392,43 t$

Flycatcher spp., 476,477

Flycatcher, Acadian, 460,476

range extension, 509

as species in forest, 432 ; orchard, 429 ; woodland, $43 f$

Flycatcher, great crested, $460,463,476,511$ habitat preferences, 513

as species in fallow fields, 415 ; forest, $\$ 32$, 435,436 ; hay, 418 ; orchard, $429,+30$; pasture, 411 ; shrubs, $\$ 26,427$; urban residential areas, 436 ; woodland, $43+$

Flycatcher, least, 460,463

Flycatcher, Traill's, 460, 476, 510

as species in corn, 398 ; hay, 118 ; marsh, 725; shrubs, 426

Flycatcher, yellow-bellied, $\$ 60,+63$

Forbes-Gross method of censusing; sec Census, strip

Forbs, +12

Forest (sce also Woodland), frontispiece, 383, $389,393,424,430-6,+35,437,438,+38$, $+39,439,+40,4+3,444,+45,+46,453,+56$, $+57,463,464,465,466,+69,+70,+71,472$, $+73,+74,+75,+76,+77,479,480,481,482$, $483,+84,485,486,488,489,+90,491,492$, $493,494,495,499,501,502,507,509,510$, $511,513,517$

acreage censused, $396,431,432-3,4+3,455$

acreage in state, $38 S,+41,457,501,502$

avifauna of, $432-3,+55$

bird populations in, $+41,457,501-2$

statistical data on populations in, 431 
G

Gallinule, common, $759,+63$

Garden crops (vegetables; see also Vegetable crops), $4+0$

acreage censused, 396

acreage in state, $\$+0,+56$

bird populations in, +56

Gnatcatcher, blue-gray, $f 61,463$

as species in forest, $732,+35$; shrubs, 427 ; woodland, 437

Goldfinch, American, 462, 462, 495-6

habitat preferences, 513,514

as species in alfalfa, 423 ; clover, $421,+22$; corn, 39S, 475, 446; fallow fields, 415, 451; forest, 432, 453,455; grassland, 413; hay, 417, 453; marsh, 425; oats, 405; orchard, 429,430 ; pasture, $410,412,450,452$; shrubs, $42+, 426,427,428,45 t$; soybeans, $401,+02,477$; wheat, 449 ; woodland, 434 Goose, blue, 459,463

Goose, Canada, 459, 463

as species in forest, 389,755 ; soybeans, $477^{\circ}$; wheat, 479

Grackle, common, $761,462,492,509,511$

habitat preferences, 513

population for all habitats in study, 507

as species in alfalfa, 423 ; clover, $+20,421$, 422 ; corn, 397,395 , 400 ; fallow fields, 414, 415 ; forest, 432; grassland, 413; hay, 41\%, 419 , 424; marsh, 424, 425; oats, 404, 405: orchard, $429,+30$; pasture, 409, 410, 450; plowed fields, 403 ; shrubs, 424, 426, 428; soybeans, 401,402 ; urban residential areas, $436,437,437$; wheat, 406, 407 ; woodland, $43 t$

Grain crops (sce also Small grain), 404

Grasslands, ungrazed (grasslands), frontispiece, 412, +13, 414, +16, 418, 42t, 438, $438,+39,439,+40,+41,4+9,+52,+64,465$, $466,469,470,471,473,474,475,477,478$, $+79,+80,+85,+86,+88,+89,+90,+91,492$, $493,494,495,496,497,498,499,501,502$, $504,506,507,508,509,513,514$

acreage censused, 396,413

acreage in state, $3 \mathcal{S} 8,4+0$

avifauna of, 413

bird populations in, $4+0$

Grebe, horned, $459,+63$

as species in marsh, 425

Grosbeak, blue, 462,463

as species in forest, $433:$ shrubs, 427

Grosbeak, rose-breasted, 462

as species in corn, 399; forest, 433

Gull, herring, 459,463

Gull, ring-billed, 459,463

\section{$\mathrm{H}$}

Habitat preferences of common species, 513, $51 t$

Habitat, summer

bird populations in, $396-4+3$

comparison of bird populations in, $437-40$. 738,439

statewide bird population estimate, $440-3$

Habitat, winter

bird populations in, 443-58

comparison of bird populations in, 453-6

statewide bird population estimate, 456-8
Habitats

and future of the avifauna, 509-15

in order of avifaunal variety, 509

in order of population densities, 509

Hawk spp.

as species in corn, 475 ; fallow fields, 415 ;

forests, 433,455 ; hay, 453 ; pasture, 411 .

450 ; plowed fields, $4+7$; small grain, $t+9$

Hawk, broad-winged, 459

Hawk, Cooper's, 459, 463

as species in forest, +33

Hawk, marsh, 459

as species in corn, 446; pasture, 411,450 ; shrubs, 454 ; wheat, 449

Hawk, red-shouldered, 459

as species in corn, 399 ; forest, 733,455 ; hay; 418 ; pasture, 450 ; plowed fields, 403

Hawk, red-tailed, $459,+63,46+-5$

as species in corn, 399, 446; fallow fields, 451 ; forest, 432, 455; pasture, 411, 450; plowed fields, 403; shrubs, 426; small grain, 448; soybeans, 447 ; woodland, 434

Hawk, rough-legged, 759

as species in corn, 445 ; hay, 453 ; wheat, 449

Hawk, sparrow, 459, 462, 464, 465-6

habitat preferences, 514

as species in corn, $398,445,4+6$; fallow fields, 415,451 ; forest, 432,455 ; hay, 417 , 453 ; oats, 405 ; pasture, 410,450 ; shrubs. 427,454 ; small grain, 448 ; wheat, $40{ }^{-}$,

Hay (hayfields), mixed (see also Hayfields), $41+-8,420,422,+38,438,439,439,4+0,4+1$, $452,+65,466,468,469,471,+72,+73,475$, $476,477,479,480,484,485,486,487,488$, $+89,490,+91,+92,493,+95,496,+97,499$, $502,507,507,508,509,510,513,517$

acreage censused, $396,416,417-8,743,453$

acreage in state, $388,4+1,457$

avifauna of, $417-8,453$

bird populations in, $4+1,457,510$

common species in, 419,424

statistical data on populations in, $\$ 16$

Hayfields (hay; see also Hay, mixed), 383, $386,389,390,391,391,393,404,418,420$, $422,438,439,443,444,456,466,467,468$, $469,470,472,473,474,476,482,484,487$, $489,490,491,495,497,499,504$

Hedgerows (hedge), 428, 466, 467, 469, 471, $472,473,477,479,480,483,484,485,487$, $491,492,493,494,495,497,498,499,505$, 510

acreage censused, 396

acreage in state, $\mathbf{4 + 2}$

bird populations in, ++2

Herbicides, 477, 485, 505, 514, 515

Heron, black-crowned night, 459

as species in corn, 399; marsh, 425 ; oats, 405 ; pasture, 411

Heron, great blue, 459

as species in corn, 399 ; forest, 433; marsh, $+25$

Heron, green, 459,463

as species in forest, 433 ; hay, 418 ; marsh, 425 ; pasture, 411

Heron, little blue, 459, 463

Highways, $4+2$

acreage in state, 512 
Hummingbird, ruby-throated, 460

as species in clover, 421 ; forest, 432 ; hav, 417 ; shrubs, 426 ; woodland, 434

Illinois, total land area, +40

Insecticides, $477,479,485,504,514,515$

$$
\mathrm{J}
$$

Jay, blue, $460,462,479-80,480,481,504,505$, 512

habitat preferences, 513,517

population for all habitats in study, 507

as species in clover, 421 ; $\operatorname{corn}, 398,+75$; fallow fields, 415, 451 ; forest, $432,+35,436$, 453, 455; grassland, 413 ; hay, 418,453 ; oats, 405 ; orchard, 429,430 ; pasture, 410 , 450 ; shrubs, $426,427,45+$; urban residential areas, 436 ; woodland, 392,434

Junco, slate-colored, $462,463,497-8,498$

habitat preferences, 514

as species in corn, 445, 446, 446; fallow fields, 451, 452; forest, 453,455 ; hay, 453 ; pasture, 450, 452; plowed fields, 447 ; shrubs, +53, $75+$; small grain, 478 ; soybeans, $4+7$; wheat, $4+9$; woodland, 392

Killdeer, $459,462,467-8$

habitat preferences, 513

as species in alfalfa, 423 ; clover, $t 21$; corn, $39 \delta, 400$; fallow fields, 415; grassland, 413; hay, 417,453 ; marsh, 425; oats, 405; pasture, 410 ; plowed fields, 401, 403; soybeans, 402 ; wheat, $4+9$

Kingbird, eastern, $460,463,476-7,504,505$

habitat preferences, 513

as species in alfalfa, 423 ; clover, 421 ; corn, 398, t00; fallow fields, 415 ; forest, 433 ; hay, 417,419 ; oats, 405 ; orchard, $429,+30$; pasture, 410 ; plowed fields, 403; shrubs, 426,428

Kingfisher, belted, 760

as species in corn, 399; forest, 432, 455 ; marsh, 425 ; pasture, 711 ; shrubs, 427

Kinglet, golden-crowned, $\$ 61$

as species in forest, 455 ; woodland, 392

Kinglet, ruby-crowned, 461,463 as species in shrubs, $75 \neq$

\section{L}

Lark, horned, 439, 457, $460,462,477-8,500$, $502,504,509,513$

habitat preferences, 513,514

population (statewide), 504

population for all habitats in study, $50 \tau$

as species in alfalfa, 423,427 ; clover, 421 , 422; corn, 392, 397, 398, 400, 400, +45, 745 , $4+6,+47$; fallow fields, $415,451,452$; grassland, 413 ; hay, $417,452,453$; oats, 405 ; pasture, $410,+50,+52$; plowed fields, 401, 403, 447, 4+8, +56; shrubs, 427; soybeans, $401,402,4+7,4+8 ;$ small grain, 478 , 449 ; wheat, $407,449,450$

Legumes, $+14,416,477,510$

Longspur, Lapland, $457,+62,500$

habitat preferences, $51 t$

as species in corn, $392,+45,+46,+76$; hay,
452,453 ; pasture, 450 ; plowed fields, 403 $\$ 47,4+8,456$; soybeans, 477 ; small grain, $4+8,+49$; wheat, $\$ 49,+50$

Longspur, Smith's, $462,+63$

\section{$M 1$}

Mallard, 459, 463

as species in forest, 455 ; marsh, 425

Man and the avifauna, 515

Man as dominant force of change, 515

Managed habitats

development of, 502-3

specialization in, 504-6

Marsh (marshland; see also Wetlands), 385 $422-4,+38,438,+39,443,463,+68,+69$ $480,484,486,487,489,490,491,492,493$ $495,496,499,501,502,504,509,510,513$ acreage censused, $396,+25,4+3$

acreage in state, $388,+41,502,510$

avifauna of, 425

bird populations in, $4+1,501-2,510$

Martin, purple, 460, 478, 503, 508

habitat preferences, 513

as species in corn, 398; fallow fields, 415 ; hay, 417; oats, 405; pasture, 410 ; soybeans, 402 ; urban residential areas, 436 437 ; wheat, 407

Meadowlark spp., 388, 389, 461, 462, 489-90, 508,512

habitat preferences, $513,51 t$

population for all habitats in study, 507

as species in alfalfa, 723,427 ; clover, 420 , $421,422,424$; corn, $398,4+5,4+6,446$; fal. low fields, $415,451,452$; forest, 433,455 ; grassland, 413 ; hay, $389,390,390,+16$ $417,418,419,427,452,453$; marsh, 424. 425 ; oats, 405 ; pasture, $410,411,412,450$ 452 ; shrubs, $426,428,45+$; small grain, $448,+49,+50-1,+57$; soybeans, $402,4+7$, 450 ; wheat, $40 \%, 4+9,+50$

Meadowlark, eastern, $388,461,489-90$

as species in alfalfa, 422 ; clover, 420 ; fallow fields, +1t; grassland, 412; hay, 416 419 ; oats, 407; orchard, $429,+30,+30$; pasture, 409; plowed fields, 403 ; wheat 408

Meadowlark, western, 388, 461, 463, 489-99

range extension, 509

as species in clover, 420 ; grassland, 412 hay, 418

Melospiza spp. in fallow fields, 451 ; hav, 418 ; shrubs, $75+$

Mockingbird, $460,483,48+, 505,508$

habitat preferences, $513,51+$

range extension, 501, 509

as species in corn, 398, 400, 445 ; fallow fields, 415,451 ; forest, 455 ; hay, 418 ; orchard, $429,+30,+30$; pasture, 410 ; plowed fields, 403 ; shrubs, 427, 454 ; soybeans, 402 ; urban residential areas, 436 ; wheat, $407,+49$

\section{$\mathrm{N}$}

Nighthawk, common, 460,512

as species in corn, 399; fallow fields, 415 ; hay, 417; orchard, 429 ; pasture, 411

Nuthatch, white-breasted, 760,462

habitat preferences, 517 
as species in cor $11,4+5 ;$ forest, $432,+53,755$; pasture, 111,750 ; shrubs, 757 ; woodland, 392

\section{$\mathrm{O}$}

Oats (oat fields), 401-7, $+38,+3 \mathcal{S},+39,+48,+66$, $+69,+70,+73,+75,477,+79,480,+84,+85$, $+86,+88,+89,+90,+91,+92,+93,+95,+96$, $+97,502,509$

acreage censused, 396, 404, 405

acreage in state, $3 S \mathcal{E},+40$

avifauna of, 705

bird populations in, $++0,++2$

common species in, 707

statistical data on populations in, 404

Open-field areas (habitat), 383, 386-7, 393, $400,+01,414,+18,424,+31,+33,+45,+46$, $468,+69,+76,+77,+78,+79,+80,487,489$, $49+, 498,510,512$

Orchard, $383,385,+2 \mathcal{S}, 429-30,438,43 \mathcal{S}, 439$, $439,+43,+66,+69,470,+71,472,+75,+76$, $477,479,480,481,+82,+83,484,+85,+87$, $488,+90,+91,492,+93,494,+95,496,497$, $498,499,504,506,509,512,513,514,514$ acreage censused, $396,429,4+3$

acreage in state, $3 \mathcal{S}, 4+1,502,511$

avifauna of, 429

bird populations in, $++1,511$

common species in, 430

Oriole, Baltimore, $461,463,509$

as species in clover, 421; corn, 399; forest, 433 ; oats, 405 ; orchard, 429 ; pasture, 410 ; shrubs, 426

Oriole, orch ard, $761,463,491-2,504,505,509$ habitat preferences, 513

population (statewide), 512

as species in clover, 421; corn, 398 ; fallow fields, 415; forest, 433 ; hay, 418 ; orchard, 429 , 430, 430 ; pasture, 410 ; shrubs, 426, +27 ; wheat, 407

Ovenbird, $461,+63$

as species in forest, $432,+36$; woodland, 434

Owl, barred, 459

as species in forest, 433

Ow], great horned, $459,+63$

as species in forest, 433,455

Owl, long-eared, 459

as species in forest, 455 ; shrubs, 454

Owl, saw-whet, $460,+63$

as species in shrubs, 454

Owl, short-eared, $460,+63$

as species in corn, 446 ; fallow fields, 451 ; small grain, $\$ 78$

\section{$P$}

Partridge, gray, $759,+63,+66$

as species in clover, 421 ; shrubs, 426

Parus, 389

Pasture (pastureland), 393, 408-12, 40S, 413 , $+18,+24,438,438,+39,439,441,443,444$, $451-2$, +52, +56, +64, +65, +66, +67, +68, $+69,470,+72,+73,474,475,+76,+77,478$, $+79,+80,+81,+83,484,+85,+86,+87,+88$, $489,490,491,+92,+93,494,+95,496,+97$, $498,499,502,504,505,510,513,514$ acreage censused, $396,409,410-1,7+3,450$ acreage in state, $388,4+0,+57$ avifauna of, $710-1,450$ bird populations in, $++0,++1,+57$ common species in, 412

populations of breerling species in, 412

statistical data on populations in, 709

Pesticides, 514, 515

Pewee, eastern wood, $460,+63,476$

as species in forest, 432,435 ; pasture, 411 ; shrubs, 726 ; urban residential areas, 436 ; woodland, 437

Pheasant, ring-necked, $383,459,463,+66$

as species in alfalfa, 723 ; clover, $+20,+21$; corn, 392, 398, 7f6; fallow fields, 715,451 ; forest, 733 ; hay, $391,717,753$; marsh, 725 ; oats, 405 ; pasture, 411 ; small grain, 448 ; soybeans, 402 : shrubs, 426

Phoebe, eastern, $460,+63,+76$

as species in corn, $39 S$; forest, 433 ; hay, $41 \mathcal{S}$; oats, 405 ; orchard, 429 ; pasture, 411 ; shrubs, 426

Pipit, Sprague's, 461, 463

as species in hay, 453

Pipit, water, 461,463

Plover, upland (see Upland plover)

Plowed fields (plowed ground), 383, 401, +38, $439,439,440,4+3,444,4+7,448,+49,452$, $456,468,469,470,475,477,480,482,483$, $486,490,495,497,500,502,509$

acreage censused, $396,403,443,447$

acreage in state, $\$ 56$

avifauna of, 403,447

bird populations in, 456

common species in, 403,417

Poa pratensis, 409

Population changes and latitude, 508

Population density and avifaunal variety, 507-8

Population density in relation to size of census area, 391, 391

Prairie, frontispicce, 443, 468, +70, 495, 501-2, 504

Quail (see Bobwhite)

Rail spp. in marsh, $\$ 25$

Rail, king, 459

as species in marsh, 425

Rail, Virginia, 459, 463 as species in marsh, 425

Railroad rights-of-way, +12

Railroad tracks, $+42,512$

Range extension of certain species (see also individual species), 508-9

Redstart, American, 461

as species in forest, 432; grassland, 413 ; shrubs, 426,428 ; woodland, 434

Roadside (roadside shrubs), $425,4+2,464,467$, $472,477,+78,479,486,488,510,51+$ acreage in state, 512

Robin, 460, 462, 485-6, 504, 505, 508, 511 habitat preferences, 513,514

population for all habitats in study, 507 as species in alfalfa, 423 ; clover, 421,422 ; corn, 398, 400, 445, 446; fallow fields, 415, 451 ; forest, 432, 453, 455; grassland, 413; hay, 417; marsh, 425 ; oats, 405 ; orchard, $429,430,430$; pasture, 410,450 ; plowed 
fields, 403 ; shrubs, $426,+27,457$; soybeans, 102; urban residential areas, 436,437 , $43 \%$; wheat, $40 \%, 4+9$; woodland, 437

Row-crop habitat (row crops), $438,439,4+0$, $+49,+52,+56,468,474,477,497,502,507$, 509,512

acreage in state, $+40,456$

bird populations in, $4+0,+56$

Rye, $+40,+48,470$

acreage censused, 396

Sandpiper, spotted, 459,467

as species in corn, $39 \mathcal{S}$; marsh, 125 ; pasture, 411; soybeans, 402

Sapsucker, yellow-bellied, $460,+63,473$ as species in forest, 455

Savanna-like habitats, $40 \mathcal{S}, 469,473,475,476$, $479,503,505,505,506,506,507,508,513$

Scaup, lesser, $459,+63$

Scientific names of birds, list of, 459-62

Sedges, $+2+$

Shrike, loggerhead, 761,462

as species in clover, 421 ; corn, 398,475 ; fallow fields, 415,451 ; hay, $41 \delta$; oats, 405; orchard, 429 ; pasture, 410 ; plowed fields, 403 ; shrubs, $45+$; small grain, 448 ; soybeans, 702

Shrike, northern, 461, 463

Shrub (shrubby) habitat (sce also Shrubgrown area and Edge), 386, 413, 429, 438 , $439,447,+45,+46,457,464,466,469,470$, $471,474,476,+77,+79,480,481,483,484$, $485,486,487,489,490,491,493,495,496$, $497,498,499,501,502,505,509,510,511$, $512,513,514$

acreage censused, 396

acreage in state, 388

Shrub-grown area or habitat (see also Shrub habitat and Edge), 383, 424-8, 437, 438, $+39,+43,452-3,+56,+66,+69,+71,+72,+73$, $474,475,+76,+80,+82,+83,48+, 485,+86$, $487,491,492,493,494,495,496,497,498$, 499

acreage censused, $+26-7,4+3,+5+$

acreage in state, $+41,+57$

avifauna of, $426-7,45 t$

bird populations in, $t+1,+57,510$

common species in, $72 \%,+2 \mathcal{S}$

Small grain, $386,438,439,4+0,+43,+4+, 4+8-9$, $451,+56,+66,+67,+68,+69,+71,+72,+74$ $477,478,481,487,490,491,493,495,496$, $497,500,502,50+, 509,510,513,517$

acreage censused, $396,+43,4+8$

acreage in state, +57

avifauna of, $7 \neq \mathcal{S}$

bird populations in, 457

Snipe, common, $459,+63,+67$

as species in marsh, $\$ 25$

Sora, $759,+63$

Soybean fields (soybeans; see also Beans), frontispiece, $383,401,+01,438,+38,+39$ $439,+40,++1,+43,+4+,+47-8,+50,+56$, $+68,+69,+77,+79,+8+,+88,+90,+91,+92$ $+95,496,497,500,514$

acreage censused, $396,402,7+3,4+7$

acreage in state, $3 \mathcal{S} \mathcal{S},++0,456$

avifauna of, $102,+17$ bird populations in, 456

statistical data on populations in, 702

Sparrow spp. in small grain, +57

Sparrow, Bachman's 462, 510

as species in fallow fields, 415 ; hay, 417 ; oats, 705 ; pasture, 411 ; shrubs, 427

Sparrow, chipping, 462, 498, 505

as species in clover, 422 ; corn, 398 ; fallow fields, 415 ; oats, 405 ; orchard, 429 ; pasture, 410 ; urban residential areas, 436

Sparrow, field, +62, 462, 498-9, 505

habitat preferences, 513,517

population for all habitats in study, 507

as species in alfalfa, 423 ; clover, $421,+22$; corn, 39S; fallow fields, $41+, 415,451$; forest, 432, 455; grassland, 413 ; hay, 417 419 ; oats, 405; orchard, 429, 430,430; pasture, $409,+10,412,+12$; plowed fields 403 ; shrubs, $424,425,426,427,42 \delta, 45 t$ : soybeans, 402 ; wheat, $40 \%$; woodland, $43+$ Sparrow, fox, t62

as species in corn, $4+5$; fallow fields, 451 . forest, 455 ; pasture, 450 ; shrubs, $45+$

Sparrow, grasshopper, $462,+63,496-7$

habitat preferences, 513

as species in alfalfa, 423 ; clover, $420,+21$, 422 ; corn, 399 ; fallow fields, 415 ; grassland, 413; hay, 389, 390,390, +16, 417. 419 ; oats, 405 ; orchard, 429 ; pasture, 410 ; shrubs, 427 ; soybeans, 702 ; wheat, $707,+08$

Sparrow, Harris', 762,463

as species in shrubs, 757

Sparrow, Henslow's, 762

as species in hay, $389,390,390,417$

Sparrow, house, $461,462,486,488-9,508,511$, 512

habitat preferences, 513,517

population (statewide), 503

population for all habitats in study, 507

as species in alfalfa, 423 ; clover, $+21,+22$, 42t; commercial urban areas, $4+1$; corn, $397,398,4+5,4+6$; fallow fields, 415,451 ; forest, 433,455 ; grassland, 413 ; hay, +17 , 419,453 ; oats, 405,407 ; orchard, 429,430 430 ; pasture, $409,410,+12,450$; plowed fields, $403,+77$; shrubs, $426,+53,+54$; small grain, $7+8$; soybeans, $402,4+7$; urban residential areas, $436,437,437$; wheat, $406,405,7+9$

Sparrow, lark, $462,497,505,512$

as species in clover, 422 ; corn, 398 ; fallow fields, 115 ; forest, 433 ; hay, 418 ; oats, 405; pasture, 410; plowed fields, t03; shrubs, 427 ; soybeans, 402 ; wheat, 407

Sparrow, Le Conte's $162,+63$

as species in fallow fields, 751 ; small grain, 478

Sparrow, savannah, $762,496,+96$

habitat preferences, 513

as species in alfalfa, $\$ 23$; clover, $420,+21$ $422,42+$; corn, $t+6$; fallow fields, $t 15$; grassland, 413 ; hay, $417,+27$; marsh, 725 ; oats, 405 ; pasture, $+10,+12,+12$; shrubs, 426 , $72 \delta$; small grain, $4+8$; soybeans, 702 , 477

Sparrow, song, +62, 463, 499-500, 508

habitat preferences, 513,517

as species in clover, 421,422 ; $\operatorname{corn}, 399,7+5$, 
ff6; fallow fields, $451,+52$; forest, 732 , +53, t55; grassland, t13; hay, 717,453 ; marsh, 425 ; oats, 705 ; orchard, 429 ; pasture, 710,450 ; shrubs, $+26,+2 \delta, 45+$; small grain, $4 \$ 5$; urban residential areas, 436 ; wheat, $t 0 i,+\neq 9$

Sparrow, swainp, 762,508

habitat preferences, $51 t$

as species in alfalfa, 723 ; fallow fields, 451 , +52; forest, 455; grassland, 713 ; hay, +17 ; marsh, 425 ; shrubs, 427,457 ; small grain, $7 \neq S$

Sparrow, tree, $762,+63,498$

habitat preferences, 517

as species in corn, $392,4+5,4+6,4+6$; fallow fields, 451, +52; forest, +53, 455; hay, 453 ; pasture, 450 , 452 ; plowed fields, 447 ; shrubs, +53, 45t; small grain, $44 \mathcal{S},+49$; wheat, $f+9,+50$; woodland, 392

Sparrow, vesper, 762,497

habitat preferences, 513

as species in alfalfa, $t 23,42+$; clover, 421 , t3t; corn, 39S, 400 ; hay, 417 ; oats, 405 ; orchard, 729 ; pasture, 410 ; shrubs, 426 , $f 2 S$; soybeans, 401,402

Sparrow, white-crowned, $+62,+63$

habitat preferences, $51 \mathrm{t}$

as species in fallow fields, 751 ; shrubs, 457 Sparrow, white-throated, 762

habitat preferences, 517

as species in corn, $7+5$; fallow fields, 751 ; forest, 455 ; shrubs, $\$ 5 t$

\section{Species}

annotated list of, $\mathbf{4 6 3 - 5 0 0}$

definition of common, 387

habitat preferences of common, 513,514

Starling, $+61,+63,+65,+73,+7+,+75,486-7$, $508,511,512,513$

habitat preferences, 513,514

population (statewide), 503

population for all habitats in study, 507

as species in alfalfa, 423 ; clover, 421,422 ,

424; commercial urban areas, 4+1; corn,

$39 S$, 476 ; fallow fields, 415, 451 ; forest, 432,455 ; grassland, 413; hay, 417, 453; marsh, 425; oats, 705 ; orchard, 429,430 ; pasture, $410,412,450$; plowed fields, 447 ; shrubs, 426, 453, 454; small grain, 448, +49 ; soybeans, 402; urban residential areas, $436,437,437$; wheat, 407,449 ; woodland, 434

Sturnella, 389

Sugar cane, 396

Swallow, bank, $460,+78$

as species in grassland, 713 ; pasture, 410 ; shrubs, $426,42 \mathrm{~S}$

Swallow, barn, 460, 463, 478-9, 509

habitat preferences, 513

as species in alfalfa, 423 ; clover, 421,422 ; corn, 39S, 400, 400; fallow fields, 415; grassland, 113 ; hay, 417,419 ; oats, 405 ; orchard, $429,430,430$; pasture, 410, 412 ; shrubs, 727 ; soybeans, 402 ; wheat, 407

Swallow, cliff, $460,+78$

as species in fallow fields, 415 ; oats, 405 ; shrubs, 427; wheat, 407

Swallow, rough-winged, $460,463,+78$ as species in clover, 421; fallow fields,
415; marsh, 425; pasture, 411: wheat, $40 \%$

Swallow, tree, $460,+63,478$

as species in corn, 399; marsh, 425 ; pasture, 411

Swift, chimney, $460,463,472-3,503$

habitat preferences, 513

as species in alfalfa, $\$ 23$; clover, $+21,422$; corn, 399 ; fallow fields, 415 ; forest, +33 ; hay, $417,+19$; oats, 705 ; orchard, 429; pasture, 710 ; plowed fields, 403 ; shrubs, 427; soybeans, 402; urban residential areas, 436,437 ; wheat, 407

\section{T}

Tables, types of, 388-9

Tanager, scarlet, 461

as species in forest, 433 ; shrubs, 427

Tanager, summer, 462

as species in clover, 421 ; forest, 432,435 ; pasture, 411 ; woodland, $\$ 37$

Teal, blue-winged, 459,463

as species in marsh, 725

Tern, black, $459,+63$

as species in hay, 417 ; marsh, 725

Thrasher, brown, 460, +63, 484, 484-5, 505

habitat preferences, 513

population (statewide), 508

population for all habitats in study, 507

as species in alfalfa, 423 ; clover, 721,422 ; corn, 398; fallow fields, 415 ; forest, 432 , +36; hay, 417, 419; marsh, 425; oats, 405 ; orchard, 429, 430; pasture, 410; plowed fields, 403; shrubs, $424,426,425$; urban residential areas, 436 ; wheat, 407 ; woodland, $43 t$

Thrush spp., 485

Thrush, hermit, 460,463

as species in shrubs, 454,455

Thrush, Swainson's, 460, 463

Thrush, wood, 460, 485

as species in forest, $432,435,435,436$; shrubs, 426, 427; urban residential areas, 436 ; woodland, $43 . t$

Timothy, +16 acreage in state, $4+1$

Titmouse, tufted, $460,+62,482-3$

habitat preferences, 513,514

range extension, 509

as species in corn, 445,446 ; forest, 432,435 , 453, 455; orchard, 429, 430,430 ; pasture, 411 ; shrubs, $426,427,454$; urban residential areas, 436 ; wheat, 449 ; woodland, 392,434

Towhee, rufous-sided, 462,462

habitat preferences, 513

as species in corn, 398 ; fallow fields, 415 ; forest, 432, 435,455 ; orchard, 429 ; pasture, 411 ; shrubs, $424,426,427,454$; urban residential areas, 436 ; woodland, $43+$

\section{$\mathrm{U}$}

Upland plover, 459, +63, +67, 468-9, 505, 506 habitat preferences, 513

as species in alfalfa, 423 ; corn, 398 ; clover, 421,422 ; fallow fields, 415 ; hay, 417,419 ; oats, 405 ; pasture, 410 ; plowed fields, 403 ; soybeans, 402 ; wheat, 407 
Urban residential areas (urban areas, residential areas), $401,424,430,436-7,438$, $438,+39,439,+40,+43,+58,+66,+69,+70$, $+71,+72,+73,+75,+79,480,+81,482,+83$, $484,+85,487,+88,+89,+91,492,493,494$, $498,502,503,504,507,508,509,511,512$, 513,515

acreage censused, 396,436

acreage in state, $3 \delta \delta,++1,502,511,512$

avifauna of, 436

bird populations in, $++1,511,512$

common species in, $\$ 37$

Urban commercial areas, bird populations in, $++1$

\section{V}

Vegetable crops (see also Garden crops), 386

Vireo, Bell's, 761, 463

range extension, 509

as species in pasture, 711 ; shrubs, 426,427

Vireo, red-eyed, 393, 761,463

as species in forest, $432,+35$; pasture, 411 ; shrubs, 427 ; urban residential areas, 436 ; woodland, 434

Vireo, warbling, $\$ 61$

as species in forest, 433 ; shrubs, 427 ; urban residential areas, $\$ 36$

Vireo, white-eyed, 761 as species in forest, $432,+35$; shrubs, 426 ; woodland, $43 t$

Vireo, yellow-throated, $\$ 61,+63$

as species in forest, 133 ; woodland, $\$ 37$

Vulture, black, 459, 463

as species in pasture, 150

Vulture, turkey, $\mathbf{4 5 9}, \mathbf{4 6 4},+83$

habitat preferences, 517

range extension, 509

as species in corn, $398,4+5$; forest, 433,455 ; hay, $41 \delta, 453$; pasture, 411,450 ; small grain, $4+8$; soybeans, 402 ; wheat, 449

\section{W}

WVarbler spp., 487

Warbler, black and white, $\$ 61$ as species in forest, $\$ 33$

Warbler, cerulean, $461,+63$ as species in forest, 732 ; woodland, 437

W' arbler, chestnut-sided, $\$ 61,463$

Wa rbler, hooded, $\$ 61,+63$ as species in forest, 733

Warbler, Kentucky, 461,463

as species in forest, $432,+35$; shrubs, 427 ; woodland, 734

W'arbler, magnolia, $\$ 61,+63$

WVarbler, myrtle, 461

as species in forest, 455 ; shrubs, $45+$

Warbler, palm, $\$ 61,463$

Warbler, parula, $\$ 61$

as species in forest, 733 ; shrubs, 727

W arbler, pine, $+61,+63$

Warbler, prairie, $\$ 61,+63,510$

as species in shrubs, 426,727

$W^{\top}$ arbler, prothonotary, 461

as species in forest, 432 ; shrubs, 427

Warbler, Swainson's, $\$ 61,463$

Warbler, worm-eating, $761,+63$

as species in forest, 432 ; woodland, 437

Warbler, yellow; 761 as species in forest, 433 ; orchard, 429,430 : shrubs, 727

Warbler, yellow-throated, $761,+63$

Waterthrush, Louisiana, 761

as species in forest, $\$ 33$

Waxwing, cedar, 761,463

as species in pasture, 450 ; shrubs, 757

Weather (climate), 384, 393-6, 394, 395, +42 , $458,464,471,478,486,498,500,508,512$

Weeds, 401, +13, +24, +49, 505

Wetlands (see also Marsh), 424, 501

Wheat (wheat fields), 407-8, +38, 438, +39 $439,4+3,4+7,4+8,449-51,+56,466,+69$, $+70,+71,+72,+74,+75,+78,+79,+80,484$ $488,490,491,492,493,494,495,496,497$ $499,509,514$

acreage censused, 396, $406,407,473,479$

acreage in state, $3 \delta \mathcal{S},+40,+57$

avifauna of, 407,479

bird populations in, $+40,+42,457$

common species in, 706

statistical data on populations in, 406

Whip-poor-will, $\$ 60,463$

as species in forest, $\$ 33$; shrubs, 427

Woodcock, American, 459, +63, 467

as species in pasture, $\$ 11$

Woodland (woods, woody habitats; see also Forest), frontispiece, 386, 389, 393, 424, $+31,+33,+36,+39,+40,+53,+56,+57,+64$, $+67,+76,+79,+81,482,+83,48+, 491,+93$, $49+, 495,498,507,511,512$

acreage in state, $4+1$

bird populations in, 392, 392, $4+1$

common species in, $73+$

Woodpecker, downy, 460 , $462,473,475-6$

habitat preferences, 513,514

as species in corn, 399, $475,4+6$; fallow fields, 415,451 ; forest, $432,+35,453,455$; hay, 418,453 ; pasture, 411,450 ; plowed fields, 403 ; small grain, $7+8$; shrubs, +26 , 45.; urban residential areas, 436 ; woodland, 392,437

Woodpecker, hairy, $\$ 60,+63,+73,+75,503$

habitat preferences, 517

as species in fallow fields, 451 ; forest, 432 , 453, 455; pasture, 411, 450 ; shrubs, $75+$; woodland, 392,437

Woodpecker, pileated, $460,463,473$ as species in forest, 433,455

Woodpecker, red-bellied, $460,+62,473,474,50$ ? habitat preferences, 514

range extension, 509

as species in corn, $475,4+6$; fallow fields, 451,452 ; forest, $432,453,455$; pasture, 411 , 450 ; shrubs, $426,45+$; small grain, 478 ; soybeans, $4+7$; woodland, 392,434

Woodpecker, red-headed, 460, 462, +73, 474-5, 505,512

habitat preferences, $513,51+$

population (statewide), 503

population for all habitats in study, 507

as species in clover, 721 ; corn, $398,400,475$; fallow fields, 415 ; forest, $432,436,453$, 455; grassland, 413; hay, $717,+19$; oats, 405 ; orchard, 429,430 ; pasture, 410 ; plowed fields, 403; shrubs, 726 , 727 ; urban residential areas, 436 ; wheat, 407 ; woodland, 434 
Wren, Bewick's, 460

as species in corn, 399 ; fallow fields, $\$ 15$; forest, 732 ; orchard, 729,430 ; pasture, t10; plowed fields, 703 ; shrubs, 426

Wren, Carolina, 760 as species in corn, 399, $4+5,46$; fallow fields, 415,451 ; forest, $432,+53,+55$; orchard, 429 ; pasture, +11 ; shrubs, 426 , 427,454 ; urban residential areas, 436 ; woodland, $392,43 t$

IVren, house, $393,+60,+63$

habitat preferences, 513

as species in forest, $f 32$; orchard, 429,430 , 430 ; pasture, $f 10$; shrubs, 426 ; urban residential areas, 736 ; woodland, 434

Wren, long-billed marsh, 460,463

as species in fallow fields, 751 ; marsh, 425
Wren, short-billed marsh, 460

as species in grassland, 413 ; hay, $f 17$; marsh, 425

Wren, winter, $\$ 60$

as species in forest, 755

\section{Y}

Yellowthroat, $461,+63,487-8$

habitat preferences, 513

as species in alfalfa, 423 ; clover, 421 ; corn, 398 ; fallow fields, 415 ; forest, 432 ; hay, 417 ; marsh, 425 ; oats, 405 ; orchard, 429, 430 ; pasture, 410 ; shrubs, $426,427,428$; wheat, 407

Z

Zonotricliia spp. in shrubs, 454 


\section{Some Publications of the Illinols Natural. History Survey}

\section{BULLETIN}

Volume 27, Article 4.-Food Habits of Migratory Ducks in Illinois. By Harry G. Anderson. August, 1959. 56 pp., frontis., 18 figs., bibliog. 50 cents.

Volume 27, Article 5.-Hook-and-Line Catch in Fertilized and Unfertilized Ponds. By Donald F. Hansen, George WW. Bennett, Robert J. Webb, and John M. Lewis. August, 1960. 46 pp., frontis., 11 figs., bibliog. Single copies free to Illinois residents; 25 cents to others.

Volume 27, Article 6.-Sex Ratios and Age Ratios in North American Ducks. By Frank C. Bellrose, Thomas G. Scott, Arthur S. Hawkins, and Jessop B. Low. August, 1961. 84 pp., 2 frontis., 23 figs., bibliog. $\$ 1.00$. (Make check payable to University of Illinois; mail check and order to Room 279 , Natural Resources Building, Urbana, Illinois.) Volume 28, Article 1.-The Amphibians and Reptiles of Illinois. By Philip W. Smith. November, 1961. 299 pp., frontis., 252 figs., bibliog., index. $\$ 3.00$.

Volume 28, Article 2.-The Fishes of Champaign County, Illinois, as Affected by 60 Years of Stream Changes. By R. Weldon Larimore and Philip W. Smith. March, 1963. 94 pp., frontis., 70 figs., bibliog., index. 50 cents.

\section{CIRCULAR}

39. - How to Collect and Preserve Insects. By H. H. Ross. July, 1962. (Sixth printing, with alterations.) 71 pp., frontis., 79 figs. Single copies free to Illinois residents; 25 cents to others.

47.-Illinois Trees and Shrubs: Their Insect Enemies. By L. L. English. March, 1962. (Second printing, with revisions.) 92 pp., frontis., 59 figs., index. Single copies free to Illinois residents; 25 cents to others.

48.-Diseases of Wheat, Oats, Barley, and Rye. By G. H. Boewe. June, 1960. 159 pp., frontis., 56 figs. Single copies free to Illinois residents; 25 cents to others.

49. - The Dunesland Heritage of Illinois. By Herbert H. Ross. (In cooperation with Illinois State Department of Conservation.) August, 1963. 28 pp., frontis., 16 figs., bibliog.

\section{BIOLOGICAL NOTES}

38.-Ectoparasites of the Cottontail Rabbit in Lee County, Northern Illinois. By Lewis J. Stannard, Jr., and Lysle R. Pietsch. June, 1958. 20 pp., 14 figs., bibliog.

39.-A Guide to Aging of Pheasant Embryos. By Ronald F. Labisky and James F. Opsahl. September, 1958. 4 pp., illus., bibliog.

40.-Night-Lighting: A Technique for Capturing Birds and Mammals. By Ronald F. Labisky. July, 1959. 12 pp., 8 figs., bibliog. 41.-Hawks and Owls: Population Trends From Illinois Christmas Counts. By Richard R. Graber and Jack S. Golden. March, 1960. 24 pp., 24 figs., bibliog.

42. - Winter Foods of the Bobwhite in Southerı Illinois. By Edward J. Larimer. May, 1960. 36 pp., 11 figs., bibliog.

43. - Hot-Water and Chemical Treatment of Illinois-Grown Gladiolus Cormels. By J. L. Forsberg. March, 1961. 12 pp., 8 figs., bibliog.

44.- The Filmy Fern in Illinois. By Robert $A$. Evers. April, 1961. 15 pp., 13 figs., bibliog. 45.-Techniques for Determining Age of Raccoons. By Glen C. Sanderson. August, 1961. 16 pp., 8 figs., bibliog.

46.- Hybridization Between Three Species of Sunfish (Lepomis). By William F. Childers and George W. Bennett. November, 1961. 15 pp., 6 figs., bibliog.

47.-Distribution and Abundance of Pheasants in Illinois. By Frederick Greeley, Ronald F. Labisky, and Stuart H. Mann. March, 1962. 16 pp., 16 figs., bibliog.

48.- Systemic Insecticide Control of Some Pests of Trees and Shrubs-A Preliminary Report. By L. L. English and Walter Hartstirn. August, 1962. 12 pp., 9 figs., bibliog. 49.-Characters of Age, Sex, and Sexual Maturity in Canada Geese. By Harold C. Hanson. November, 1962. 15 pp., 13 figs., bibliog. 50.- Some Unusual Natural Areas in Illinois and a Few of Their Plants. By Robert $A$. Evers. July, 1963. 32 pp., 43 figs., bibliog.

\section{MANUAL}

4. - Fieldbook of Illinois Mammals. By Donald F. Hoffmeister and Carl O. Mohr. June, 1957. 233 pp., color frontis., 119 figs., glossary, bibliog., index. $\$ 1.75$.

List of available publications mailed on request

Single copies of IlliNoIS Natural History SURvey publications for which no price is listed will be furnished free of charge to individuals until the supply becomes low, after which a nominal charge may be made. More than one copy of any free publication may be obtained without cost by educational institutions and official organizations within the State of Illinois; prices to others on quantity orders of these publications will be quoted upon request.

Address orders and correspondence to the Chief, IlliNOIS NATURAL History SuRvey, Natural Resources Building, Urbana, Illinois

Payment in the form of money order or check made out to State Treasurer of Illinois, Springfield, Illinois, must accompany requests for those publications on which a price is set. 